\title{
STATE OF THE CLIMATE IN 2020
}

\section{REGIONAL CLIMATES}

P. Bissolli, C. Ganter, T. Li, A. Mekonnen, and A. Sánchez-Lugo, Eds.



Special Online Supplement to the Bulletin of the American Meteorological Society Vol.102, No. 8, August, 2021

https://doi.org/10.1175/2021BAMSStateoftheClimate_Chapter7.1

Corresponding authors:

North America: Ahira Sánchez-Lugo / Ahira.Sanchez-Lugo@noaa.gov.

Central America and the Caribbean: Ahira Sánchez-Lugo / Ahira.Sanchez-Lugo@noaa.gov

South America: Ahira Sánchez-Lugo / Ahira.Sanchez-Lugo@noaa.gov

Africa: Ademe Mekonnen / amekonne@ncat.edu

Europe: Peter Bissolli / Peter.Bissolli@dwd.de

Asia: Tim Li / timli@hawaii.edu

Oceania: Catherine Ganter / Catherine.Ganter@bom.gov.au

(C)2021 American Meteorological Society

For information regarding reuse of this content and general copyright information, consult the AMS Copyright Policy. 


\title{
STATE OF THE CLIMATE IN 2020 Regional Climates
}

\author{
Editors \\ Jessica Blunden \\ Tim Boyer \\ Chapter Editors \\ Freya Aldred \\ Peter Bissolli \\ Howard J. Diamond \\ Matthew L. Druckenmiller \\ Robert J. H. Dunn \\ Catherine Ganter \\ Nadine Gobron \\ Gregory C. Johnson \\ Rick Lumpkin \\ Tim Li \\ Ademe Mekonnen \\ John B. Miller \\ Twila A. Moon \\ Ahira Sánchez-Lugo \\ Ted A. Scambos \\ Carl J. Schreck III \\ Sharon Stammerjohn \\ Richard L. Thoman \\ Kate M. Willett \\ Technical Editor \\ Andrea Andersen
}

BAMS Special Editor for Climate

Michael A. Alexander

American Meteorological Society 


\section{Cover credit:}

Rights Managed Photo by STR/AFP via @Getty Images

Flooded buildings are seen in Nanjing, in China's eastern Jiangsu province on 19 July 2020.

Vast swaths of China were inundated by the worst flooding in decades along the Yangtze River.

Regional Climates is one chapter from the State of the Climate in 2020 annual report. Compiled by NOAA's National Centers for Environmental Information, State of the Climate in 2020 is based on contributions from scientists from around the world. It provides a detailed update on global climate indicators, notable weather events, and other data collected by environmental monitoring stations and instruments located on land, water, ice, and in space. The full report is available from https://doi.org/10.1175/2021BAMSStateoftheClimate.1.

\section{How to cite this document:}

\section{Citing the complete report:}

Blunden, J. and T. Boyer, Eds., 2021: "State of the Climate in 2020". Bull. Amer. Meteor. Soc, 102 (8), Si-S475, https://doi.org/10.1175/2021BAMSStateoftheClimate.1

\section{Citing this chapter:}

Bissolli, P., C. Ganter, T. Li, A. Mekonnen, and A. Sánchez-Lugo, Eds., 2021: Regional Climates [in "State of the Climate in 2020"]. Bull. Amer. Meteor. Soc., 102 (8), S357-S463,

https://doi.org/10.1175/2021BAMSStateoftheClimate_Chapter7.1.

\section{Citing a section (example):}

Thiaw, W. M., P.-H. Kamsu-Tamo, M. F. Zaheer, and B. Pugh, 2021: Central Asia [in "State of the Climate in 2020"]. Bull. Amer. Meteor. Soc., 102 (8), S441-S445,

https://doi.org/10.1175/2021BAMSStateoftheClimate_Chapter7.1 
Alfaro, Eric J., Center for Geophysical Research and School of Physics, University of Costa Rica, San José, Costa Rica

Alves, Lincoln M., Centro de Ciencia do Sistema Terrestre/Instituto Nacional de Pesquisas Espaciais, Sao Paulo, Brazil

Amador, Jorge A., Center for Geophysical Research and School of Physics, University of Costa Rica, San José, Costa Rica

Andrade, B., Seychelles Meteorological Authority, Mahe, Seychelles

Argeñalso, Francisco, Centro Nacional de Estudios Atmosféricos, Oceanográficos y Sísmicos, Tegucigalpa, Honduras

Asgarzadeh, P., National Center for Climate and Drought Crisis Management, Islamic Republic of Iranian Meteorological Organization, Iran

Baez, Julian, Universidad Católica Nuestra Senora de la Asunción, Asunción, Paraguay

Barakiza, Reuben, Burundi Hydrometeorological Department, Bujumbura, Burundi

Bardin, M. Yu., Yu. A. Izrael Institute of Global Climate and Ecology; Institute of Geography, Russian Academy of Sciences, Russia

Bardin, Mikhail, Institute of Global Climate and Ecology, Moscow, Russia

Bissolli, Peter, Deutscher Wetterdienst, WMO RA VI Regional Climate Centre Network, Offenbach, Germany

Bochníček, Oliver, Slovak Hydrometeorological Institute, Slovakia

Bukunt, Brandon, NOAA/NWS Weather Forecast Office, Guam

Calderón, Blanca, Center for Geophysical Research, University of Costa Rica, San José, Costa Rica

Campbell, Jayaka D., Department of Physics, The University of the West Indies, Jamaica

Chandler, Elise, Bureau of Meteorology, Melbourne, Victoria, Australia

Chang'a, Ladislaus, Tanzania Meteorological Authority, Dar es Salaam, Tanzania

Cheng, Vincent Y. S., Environment and Climate Change Canada, Toronto, Ontario, Canada

Clarke, Leonardo A., Department of Physics, The University of the West Indies, Jamaica

Correa, Kris, Servicio Nacional de Meteorología e Hidrología del Perú, Lima, Perú

Cortés, Catalina, Dirección de Meteorológica de Chile, Santiago de Chile, Chile

Costa, Felipe, International Centre for Research on El Niño, Guayaqui, Ecuador

Cunha, A.P.M.A., Centro Nacional de Monitoramento e Alertas de Desastres Naturais CEMADEN, Sao Paulo, Brazil

Demircan, Mesut, Turkish State Meteorological Service, Ankara, Turkey

Dhurmea, K. R., Mauritius Meteorological Service, Vacoas, Mauritius

Diawara, A., NOAA/NWS National Centers for Environmental Prediction, Climate Prediction Center, College Park, Maryland

Diouf, Sarah, NOAA/NWS National Centers for Environmental Prediction, Climate Prediction Center, College Park, Maryland

Dulamsuren, Dashkhuu, Climate change and resource research section, Information and Research, Institute of Meteorology, Hydrology and Environment, National Agency for Meteorology, Hydrology and Environmental Monitoring, Ulaanbaatar, Mongolia

ElKharrim, M., Direction de la Météorologie Nationale Maroc, Rabat, Morocco

Espinoza, Jhan-Carlo, Université Grenoble Alpes, Institut des Géosciences de I'Environnement, IRD, CNRS, Grenoble INP, Grenoble, France

Fazl-Kazem, A., National Center for Drought Monitoring and Crisis Management, Islamic Republic of Iranian Meteorological Organization, Iran

Fenimore, Chris, NOAA/NESDIS National Centers for Environmental Information, Asheville, North Carolina

Fuhrman, Steven, NOAA/NWS National Centers for Environmental Prediction, Climate Prediction Center, College Park, Maryland
Ganter, Catherine, Bureau of Meteorology, Melbourne, Victoria, Australia

Gleason, Karin, NOAA/NESDIS National Centers for Environmental Information, Asheville, North Carolina

Guard, Charles "Chip" P., Tropical Weather Sciences, Sinajana, Guam

Hagos, Samson, Pacific Northwest National Laboratory, Department of Energy, Richland, Washington

Hanafusa, Mizuki, Tokyo Climate Center, Japan Meteorological Agency, Japan

Hasannezhad, H. R., National Center for Climate and Drought Crisis Management, Islamic Republic of Iranian Meteorological Organization, Iran

Heim, Jr., Richard R., NOAA/NESDIS National Centers for Environmental Information, Asheville, North Carolina

Hidalgo, Hugo G., Center for Geophysical Research and School of Physics, University of Costa Rica, San José, Costa Rica

Ijampy, J. A., Nigerian Meteorological Agency, Abuja, Nigeria

Im, Gyo Soon, Climate Change Monitoring Division, Korea Meteorological Administration, South Korea

Joseph, Annie C., Dominica Meteorological Service, Canefield, Dominica

Jumaux, G., Météo France, Direction Interrégionale pour l'Océan Indien, Réunion

Kabidi, K. R., Direction de la Météorologie Nationale Maroc, Rabat, Morocco

Kamsu-Tamo, P-H., NOAA/NWS National Centers for Environmental Prediction, Climate Prediction Center, College Park, Maryland

Kennedy, John, Met Office Hadley Centre, Exeter, United Kingdom

Khan, Valentina, Hydrometeorological Research Center of the Russian Federation/A.M. Obukhov Institute of Atmospheric Physics, Russian Academy of Sciences, Moscow, Russia

Khiem, Mai Van, Viet Nam National Center of Hydro-Meteorology Forecasting, Viet Nam Meteorology Hydrology Administration, Viet Nam

King'uza, Philemon, Tanzania Meteorological Authority, Dar es Salaam, Tanzania

Korshunova, Natalia N., All-Russian Research Institute of Hydrometeorological Information - World Data Center, Obninsk, Russia

Kruger, A. C., Climate Service, South African Weather Service, Pretoria, South Africa Lakatos, Mónika, Climatology Unit, Hungarian Meteorological Service, Budapest, Hungary

Lam, Hoang Phuc, Viet Nam National Center of Hydro-Meteorology Forecasting, Viet Nam Meteorology Hydrology Administration, Viet Nam

Lander, Mark A., University of Guam, Mangilao, Guam

Lavado-Casimiro, Waldo, Servicio Nacional de Meteorología e Hidrología del Perú, Lima, Perú

Lee, Tsz-Cheung, Hong Kong Observatory, Hong Kong, China

Leung, Kinson H. Y., Environment and Climate Change Canada, Toronto, Ontario, Canada

Li, Tim, Department of Atmospheric Sciences, University of Hawaii, Honolulu, Hawaii, USA

Macara, Gregor, National Institute of Water and Atmospheric Research, Ltd., Auckland, New Zealand

Mamen, Jostein, Climate Division, Norwegian Meteorological Institute, Oslo, Norway

Marengo, José A., Centro Nacional de Monitoramento e Alertas de Desastres Naturais CEMADEN, Sao Paulo, Brazil

McBride, Charlotte, Climate Service, South African Weather Service, Pretoria, South Africa

Mekonnen, Ademe, Department of Physics, North Carolina A \& T University, Greensboro, North Carolina

Misevicius, Noelia, Instituto Uruguayo de Meteorología, Montevideo, Uruguay

Moise, Aurel, Centre for Climate Research Singapore, Meteorological Service, Singapore 
Molina-Carpio, Jorge, Universidad Mayor de San Andrés, La Paz, Bolivia

Mora, Natali, Center for Geophysical Research, University of Costa Rica, San José, Costa Rica

Mostafa, Awatif E., Department of Seasonal Forecast and Climate Research, Cairo Numerical Weather Prediction, Egyptian Meteorological Authority, Cairo, Egypt

Mtongori, Habiba, Tanzania Meteorological Authority, Dar es Salaam, Tanzania

Mutai, Charles, Kenya Meteorological Department, Nairobi, Kenya

Ndiaye, 0., Senegalese Meteorological Service, Dakar, Senegal

Nieto, Juan José, International Centre for Research on El Niño, Guayaqui, Ecuador

Nyembo, Latifa, Tanzania Meteorological Authority, Dar es Salaam, Tanzania

Nying'uro, Patricia, Kenya Meteorological Department, Nairobi, Kenya

Pan, Xiao, Nanjing University of Information Science and Technology, China

Pascual Ramírez, Reynaldo, National Meteorological Service of Mexico, Mexico City, Mexico

Phillips, David, Environment and Climate Change Canada, Toronto, Ontario, Canada

Pugh, Brad, NOAA/NWS National Centers for Environmental Prediction, Climate Prediction Center, College Park, Maryland

Rajeevan, Madhavan, Earth System Science Organization, Ministry of Earth Sciences, New Delhi, India

Rakotonirina, M. L., Madagascar Meteorological Service, Madagascar

Ramos, Andrea M., Instituto Nacional de Meteorologia, Brasilia, Brazil

Robjhon, M., NOAA/NWS National Centers for Environmental Prediction, Climate Prediction Center, College Park, Maryland

Rodriguez Camino, Ernesto, Agencia Estatal de Meteorología, Madrid, Spain

Rodriguez Guisado, Esteban, Agencia Estatal de Meteorología, Madrid, Spain

Ronchail, Josyane, Laboratoire LOCEAN-IPSL, Paris, France

Rösner, Benjamin, Laboratory for Climatology and Remote Sensing, Faculty of Geography, University of Marburg, Marburg, Germany

Salinas, Roberto, Dirección de Meteorología e Hidrología/Dirección Nacional de Aeronáutica Civil, Asunción, Paraguay

Sánchez-Lugo, Ahira, NOAA/NESDIS National Centers for Environmental Information, Asheville, North Carolina

Sato, Hirotaka, Tokyo Climate Center, Japan Meteorological Agency, Japan Sato, Hitoshi, Tokyo Climate Center, Japan Meteorological Agency, Japan Sayouri, Amal, Direction de la Météorologie Nationale Maroc, Rabat, Morocco Sebaziga, Joseph, Rwanda Meteorology Agency, Kigali, Rwanda

Sensoy, Serhat, Turkish State Meteorological Service, Ankara, Turkey

Spillane, Sandra, Met Éireann, Dublin, Ireland
Trachte, Katja, Brandenburg University of Technology, Cottbus, Germany van der Schrier, Gerard, Royal Netherlands Meteorological Institute, De Bilt, Netherlands

Sima, F., Division of Meteorology, Department of Water Resources, Banjul, The Gambia

Smith, Adam, NOAA/NESDIS National Centers for Environmental Information, Asheville, North Carolina

Spence, Jacqueline M., Meteorological Service, Jamaica, Kingston, Jamaica

Sreejith, 0. P., India Meteorological Department, Pune, India

Srivastava, A. K., India Meteorological Department, Pune, India

Stella, José L., Servicio Meteorológico Nacional, Buenos Aires, Argentina

Stephenson, Kimberly A., Department of Life Sciences, The University of the West Indies, Jamaica

Stephenson, Tannecia S., Department of Physics, The University of the West Indies, Jamaica

Supari, S., Division for Climate Variability Analysis, Center for Climate Change Information, BMKG, Indonesia

Tajbakhsh-Mosalman, Sahar, Islamic Republic of Iranian Meteorological Organization, Iran

Tamar, Gerard, Grenada Meteorological Office, St. George, Grenada

Taylor, Michael A., Department of Physics, The University of the West Indies, Jamaica

Teshome, Asaminew, Ethiopia Meteorological Agency, Addis Ababa, Ethiopia

Thiaw, Wassila M., NOAA/NWS National Centers for Environmental Prediction, Climate Prediction Center, College Park, Maryland

Tobin, Skie, Bureau of Meteorology, Melbourne, Victoria, Australia

Trotman, Adrian R., Caribbean Institute for Meteorology and Hydrology, Bridgetown, Barbados

Van Meerbeeck, Cedric J., Caribbean Institute for Meteorology and Hydrology, Bridgetown, Barbados

Vazifeh, A., National Center for Drought Monitoring and Crisis Management, Islamic Republic of Iranian Meteorological Organization, Iran

Wakamatsu, Shunya, Tokyo Climate Center, Japan Meteorological Agency, Japan

Wang, Wei, Minhang Meteorological Bureau, Shanghai, China

Xin, Fei, Shanghai Climate Center, Shanghai, China

Zeng, F., Pacific Northwest National Laboratory, Department of Energy, Richland, Washington

Zhang, Peiqun, Beijing Climate Center, Beijing, China

Zhu, Zhiwei, Nanjing University of Information Science and Technology, China

\section{Editorial and Production Team}

Allen, Jessicca, Graphics Support, Cooperative Institute for Satellite Earth System Studies, North Carolina State University, Asheville, North Carolina

Andersen, Andrea, Technical Editor, Innovative Consulting Management Services, LLC, NOAA/NESDIS National Centers for Environmental Information, Asheville, North Carolina

Hammer, Gregory, Content Team Lead, Communications and Outreach, NOAA/NESDIS National Centers for Environmental Information, Asheville, North Carolina

Love-Brotak, S. Elizabeth, Lead Graphics Production, NOAA/NESDIS National Centers for Environmental Information, Asheville, North Carolina
Misch, Deborah J., Graphics Support, Innovative Consulting Management Services, LLC, NOAA/NESDIS National Centers for Environmental Information, Asheville, North Carolina

Riddle, Deborah B., Graphics Support, NOAA/NESDIS National Centers for Environmental Information, Asheville, North Carolina

Veasey, Sara W., Visual Communications Team Lead, Communications and Outreach, NOAA/NESDIS National Centers for Environmental Information, Asheville, North Carolina 


\section{Table of Contents}

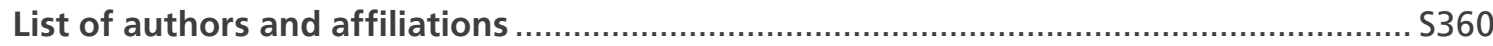

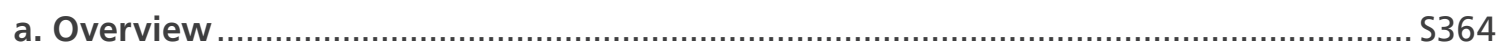

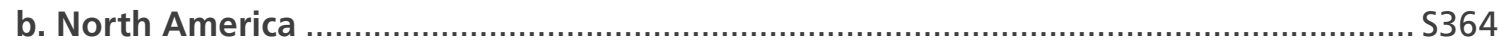





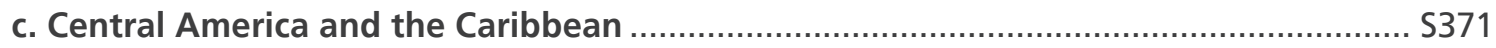

1. Central America ........................................................................................... S371

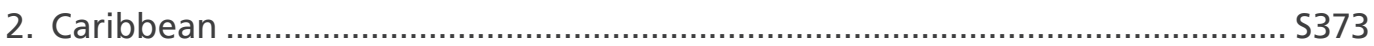

Sidebar 7.1: Record-breaking hurricane landfalls in Central America ............................... S376

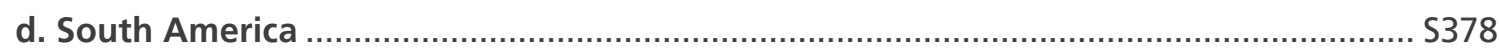

1. Northern South America ........................................................................ S378

2. Central South America...................................................................................... $\$ 388$

3. Southern South America .......................................................................... S383

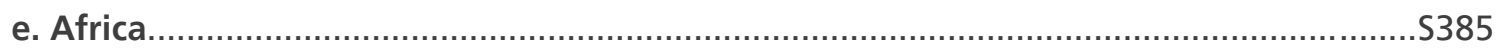

1. North Africa ....................................................................................... 3386

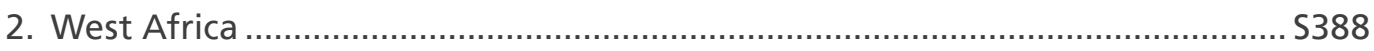

3. Central Africa ............................................................................................. S392

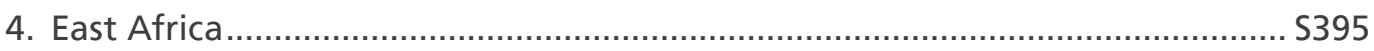

5. Southern Africa ......................................................................................... S398

6. Western Indian Ocean island countries ......................................................... S402



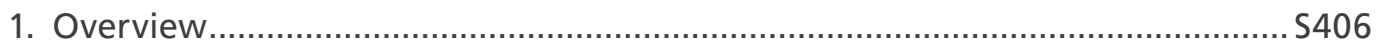

2. Western Europe................................................................................. $\mathrm{S} 410$

3. Central Europe …............................................................................... 5412

4. The Nordic and Baltic countries ................................................................... 5414

5. Iberian Peninsula ........................................................................................ 5416

6. Central Mediterranean region ................................................................... 4417

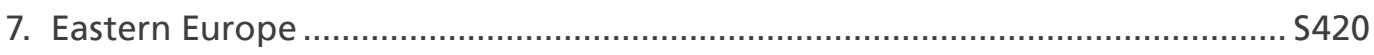

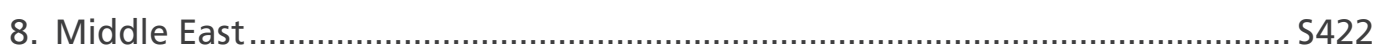

9. Turkey and South Caucasus ........................................................................... S424

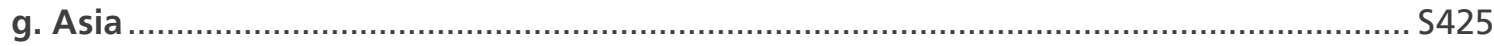

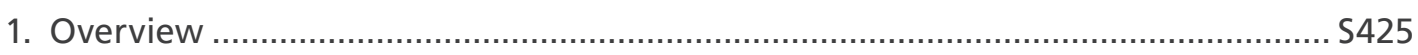

2. Russia ................................................................................................ S426

3. East and Southeast Asia ....................................................................... S432

Sidebar 7.2: Extreme floods along the Meiyu/Baiu/Changma front in summer 2020...... S435

4. South Asia................................................................................................ 5437

5. Southwest Asia ...................................................................................... $\$ 440$

6. Central Asia ........................................................................................... S441 


\section{Table of Contents}

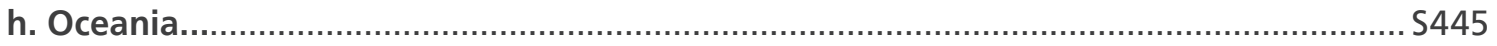

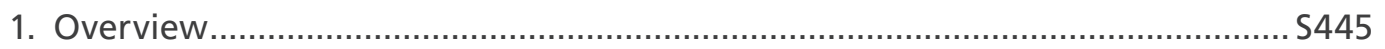

2. Northwest Pacific and Micronesia..................................................................... $\mathrm{S} 445$

Sidebar 7.3: Clear La Niña signal in Micronesian typhoon tracks of 2020........................ S448

3. Southwest Pacific ..................................................................................... $\mathrm{S} 449$

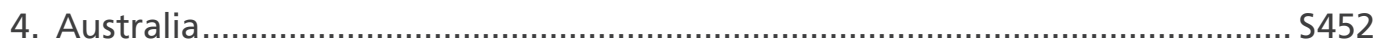

5. Aotearoa New Zealand ............................................................................. S45

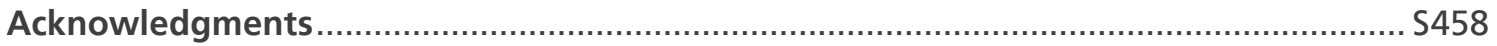

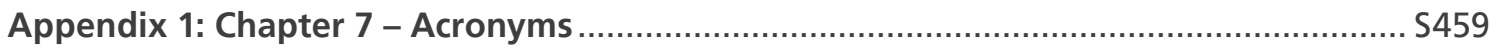

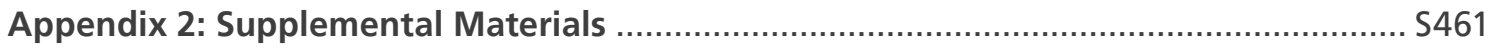

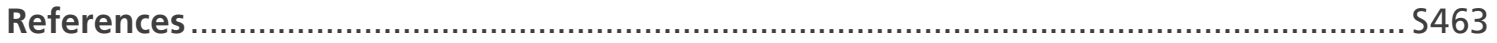

*Please refer to Chapter 8 (Relevant datasets and sources) for a list of all climate variables and datasets used in this chapter for analyses, along with their websites for more information and access to the data. 


\section{REGIONAL CLIMATES}

P. Bissolli, C. Ganter, T. Li, A. Mekonnen, and A. Sánchez-Lugo, Eds.

\section{a. Overview}

This chapter provides summaries of the 2020 temperature and precipitation conditions across seven broad regions: North America, Central America and the Caribbean, South America, Africa, Europe and the Middle East, Asia, and Oceania. In most cases, summaries of notable weather events are also included. Local scientists provided the annual summary for their respective regions and, unless otherwise noted, the source of the data used is typically the agency affiliated with the authors. The primary base period used for these analyses is 1981-2010. However, please note that on occasion different nations, even within the same section, may use unique periods to define their normals. Section introductions typically define the prevailing practices for that section, and exceptions will be noted within the text. Similarly, many contributing authors use languages other than English as their primary professional language. To minimize additional loss of fidelity through re-interpretation after translation, editors have been conservative and careful to preserve the voice of the author. In some cases, this may result in abrupt transitions in style from section to section.

b. North America-A. Sánchez-Lugo, Ed.

1) Canada-K. H. Y. Leung, V. Y. S. Cheng, and D. Phillips

In Canada, 2020 was characterized by a warmer-than-average winter in most of southern Canada and southern Nunavut and by a cooler-than-average spring in most of Canada, with the exception of the northern parts of Yukon, Northwest Territories, and Nunavut. The country also experienced a warmer-than-average summer over most of Nunavut and eastern Canada and a warmer-than-average autumn in northern Nunavut. Autumn was cooler than-average across most of western and southern parts of northern Canada.

\section{(I) TEMPERATURE}

The 2020 annual average temperature for Canada was $0.3^{\circ} \mathrm{C}$ above the $1981-$ 2010 average and the 14 th-warmest year since nationwide records began in 1948 (Fig. 7.1). Four of the 10 warmest years have occurred during the last decade, with 2010 the warmest year on record $\left(2.2^{\circ} \mathrm{C}\right.$ above average). The national annual average temperature record has increased $1.8^{\circ} \mathrm{C}$ over the past 73 years. Spatially, annual anomalies above $+0.5^{\circ} \mathrm{C}$ were recorded in far northern and parts of eastern Canada. Annual anomalies below $-0.5^{\circ} \mathrm{C}$ were observed mainly in the southern areas of Yukon, Northwest

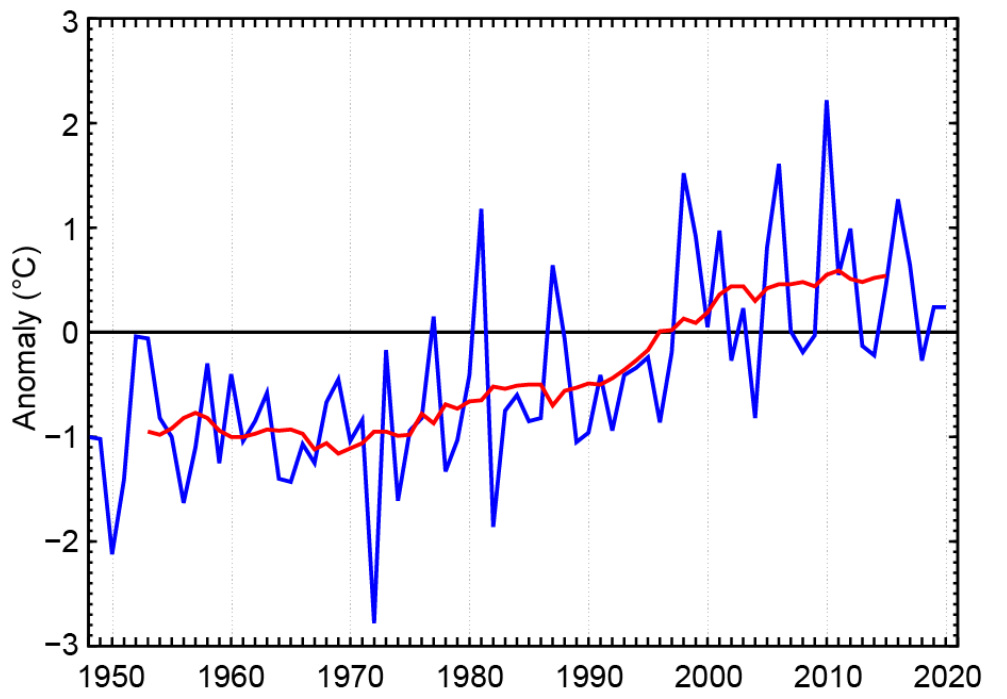

Fig. 7.1. Annual average temperature anomalies $\left({ }^{\circ} \mathrm{C}\right.$; 1981-2010 base period) in Canada for 1948-2020. Red line is the 11-year running mean. (Source: Environment and Climate Change Canada.) 
Territories, Nunavut, interior British Columbia, and the Prairie regions (Fig. 7.2). Four provinces/territories (Nova Scotia, New Brunswick, Prince Edward Island, and Quebec) recorded an average annual temperature among their 10 warmest on record.

Seasonally, the nationally averaged winter (December-February) 2019/20 temperature was $0.7^{\circ} \mathrm{C}$ above average-the 17 th-warmest winter on record. Winter anomalies more than $2.0^{\circ} \mathrm{C}$ above average were recorded over Ontario, Manitoba, most of Saskatchewan, parts of southern Nunavut, and western Quebec. Ontario and Manitoba reported their seventh- and eighth-warmest winters on record, respec-

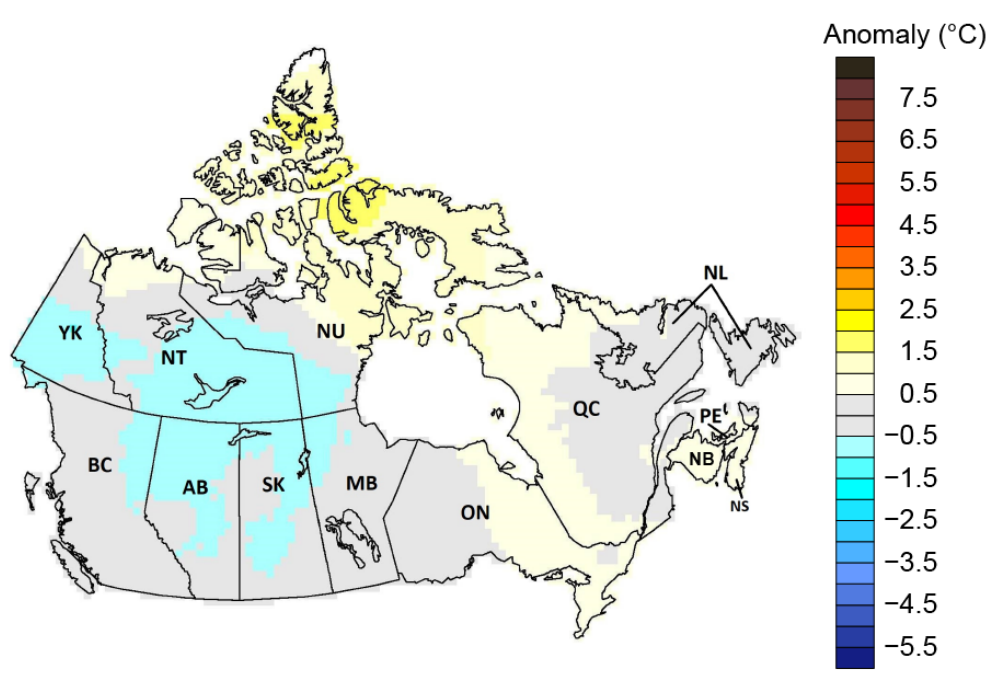

Fig. 7.2. Annual average temperature anomalies $\left({ }^{\circ} \mathrm{C} ; 1981-2010\right.$ base period) in Canada for 2020. (Source: Environment and Climate Change Canada.)

tively. The majority of Yukon and Northwest Territories, and some areas in the northern parts of Nunavut and Newfoundland experienced below-average winter temperatures. The national average temperature for the winter season has increased by $3.3^{\circ} \mathrm{C}$ over the past 73 years, the most of any season.

The national average temperature for spring (March-May) 2020 was $0.7^{\circ} \mathrm{C}$ below average and the 31st lowest in the 73-year record. Below-average temperatures were recorded over most of Canada, with temperatures anomalies of $-3.0^{\circ} \mathrm{C}$ observed in the northern Prairies region. Above-average conditions were observed only over parts of northern Canada, with departures from average more than $+1.5^{\circ} \mathrm{C}$ in some areas. No province or territory experienced an average spring temperature among its 10 highest or lowest. The national average spring temperature has increased by $1.6^{\circ} \mathrm{C}$ over the past 73 years.

The national average summer (June-August) temperature was $0.6^{\circ} \mathrm{C}$ above average and the sixth highest since 1948. Central Nunavut and northern Quebec experienced anomalies more than $+1.5^{\circ} \mathrm{C}$, with Nunavut, New Brunswick, and Prince Edward Island all observing their fifthwarmest summer on record. Other provinces also had an average summer temperature among their 10 warmest: Ontario (sixth warmest), Quebec (seventh warmest), Nova Scotia (seventh warmest), and Newfoundland (ninth warmest). Areas from the interior of British Columbia to southern Yukon and Northwest Territories, along with a small region in southern Saskatchewan, experienced below-average summer temperatures. The national average summer temperature has increased by $1.5^{\circ} \mathrm{C}$ over the past 73 years.

The national average temperature for autumn (September-November) 2020 was $0.1^{\circ} \mathrm{C}$ above average and the 36th warmest since 1948 . Temperatures anomalies above $+2.5^{\circ} \mathrm{C}$ were observed across northern Nunavut. Autumn anomalies of $-1^{\circ} \mathrm{C}$ or below were reported in southern areas of Yukon, Northwest Territories, and Nunavut, and most of the prairies provinces to northwestern Ontario. The national autumn temperature has increased by $1.6^{\circ} \mathrm{C}$ over the past 73 years.

\section{(II) PRECIPITATION}

Over the past decade, precipitation monitoring technology has evolved, and Environment and Climate Change Canada (ECCC) and its partners implemented a transition from manual observations to the use of automatic precipitation gauges. Extensive data integration is required to link the current precipitation observations to the long-term historical manual observations. The update and reporting of historical adjusted precipitation trends and variations will be on temporary hiatus pending an extensive data reconciliation and resumed thereafter. ECCC remains committed 
to providing credible climate data to inform adaptation decision making, while ensuring the necessary data reconciliation occurs as monitoring technology evolves.

\section{(III) NOTABLE EVENTS AND IMPACTS}

On 16 January, a deep low-pressure system situated over western New York tracked through the northeastern United States to Newfoundland's Avalon Peninsula (a normal track for a mid-winter storm). As the storm deepened and strengthened, its central pressure dropped more than $54 \mathrm{hPa}$ in 48 hours. Intense snow began falling early on 17 January, and blizzard conditions prevailed for 18 straight hours, with visibility decreasing to $200 \mathrm{~m}$ or less. The historical daily snowfall record was broken at St. John's International Airport, with over $75 \mathrm{~cm}$ recorded. Nearby, Mount Pearl and Paradise, Newfoundland, reported $90 \mathrm{~cm}$ of snow over a 28-hour period. An average snowfall intensity of $10 \mathrm{~cm}$ per hour was also recorded in St. John's and the surrounding regions. The last time St. John's experienced close to $75 \mathrm{~cm}$ of snowfall in a single day was in April 1999. Wind speeds during the blizzard reached hurricane force at $160 \mathrm{~km} \mathrm{~h}^{-1}$ along the coast and $125 \mathrm{~km} \mathrm{~h}^{-1}$ at St. John's International Airport. The deep low and strong winds also generated a significant storm surge with a wave height of $8.7 \mathrm{~m}$ on 18 January, damaging docks and boats. This storm contributed to the snowiest January on record for St. John's.

On 13 June, warm and humid air over Alberta generated multiple rounds of severe thunderstorm cells. With colliding winds at various heights over southern Alberta, the wind shear helped fuel large, long-lived thunderstorms. That same day, a severe thunderstorm cell with a hail core passed over northeastern Calgary, producing tennis-ball size hail and wind speeds up to 70 $\mathrm{km} \mathrm{h}^{-1}\left(\sim 20 \mathrm{~m} \mathrm{~s}^{-1}\right)$. The violent hailstorm shook houses, broke windows, damaged vehicles, and downed trees, which led to power outages to more than 10,000 customers and hail almost $10 \mathrm{~cm}$ deep piled up along roads. The damage incurred from this storm was Canada's costliest and the fourth-most expensive insured natural disaster in Canadian history, with Canadian insurers estimating at about $\$ 1.3$ billion (Canadian dollars; $\$ 1$ billion [U.S. dollars]) in losses. This value excludes crop losses.

On 2 August, the warm front of a low-pressure system brought significant tropical-sourced moisture (50-70 mm) eastward from Windsor to the Greater Toronto Area and Niagara region and along the north shore of Lake Ontario. Rainfall in the city of Barrie totaled between 80-90 mm, its highest August 1-day rainfall total on record and highest 1-day total for any month in the past 25 years. The same storm system also spawned four tornadoes with winds estimated between 130 and $190 \mathrm{~km} \mathrm{~h}^{-1}$ (EF-0 to EF-2 on the Enhanced Fujita Scale) in southern Ontario.

During 6-7 August, a low-pressure system from Alberta moved eastward toward Manitoba and generated many severe thunderstorm cells that produced large hail, powerful winds, and torrential downpours. On 7 August, an EF-3 tornado touched down near Scarth in western Manitoba, $13 \mathrm{~km}$ south of Virden. Wind speeds associated with the deadly tornado exceeded $200 \mathrm{~km} \mathrm{~h}^{-1}$ for between 10-15 minutes and reached wind speeds estimated as high as $260 \mathrm{~km} \mathrm{~h}^{-1}$. The tornado left a 9-km long path of destruction and caused two fatalities.

\section{2) United States-K. Gleason, C. Fenimore, R. R. Heim Jr., and A. Smith}

The annual average temperature for the contiguous United States (CONUS) in 2020 was $12.4^{\circ} \mathrm{C}$, which was $0.9^{\circ} \mathrm{C}$ above the $1981-2010$ average and was the fifth-warmest year in the 126-year record, with the five warmest years all occurring since 2012 (Fig. 7.3a). Much of the country experienced temperature anomalies at least $+1^{\circ} \mathrm{C}$ or more above average (Fig. 7.4a). Exceptions to this warmth occurred across parts of the Plains, Midwest, and Northwest. Based on a linear regression of data from 1895 to 2020, the annual CONUS temperature over the 126-year record is increasing at an average rate of $0.09^{\circ} \mathrm{C}$ decade $^{-1}\left(0.27^{\circ} \mathrm{C}\right.$ decade ${ }^{-1}$ since 1970$)$. Across Alaska, the average annual temperature in 2020 was $0.11^{\circ} \mathrm{C}$ above average and was the coldest year since 2012 . 



Fig. 7.3. Annual (a) mean temperature anomalies $\left({ }^{\circ} \mathrm{C}\right)$ and $(\mathrm{b})$ precipitation anomalies $(\mathrm{mm})$ for the CONUS during $1895-2020$ (1981-2010 base period). Red line is the lagged 10-year running mean. (Source: NOAA/NCEI.)

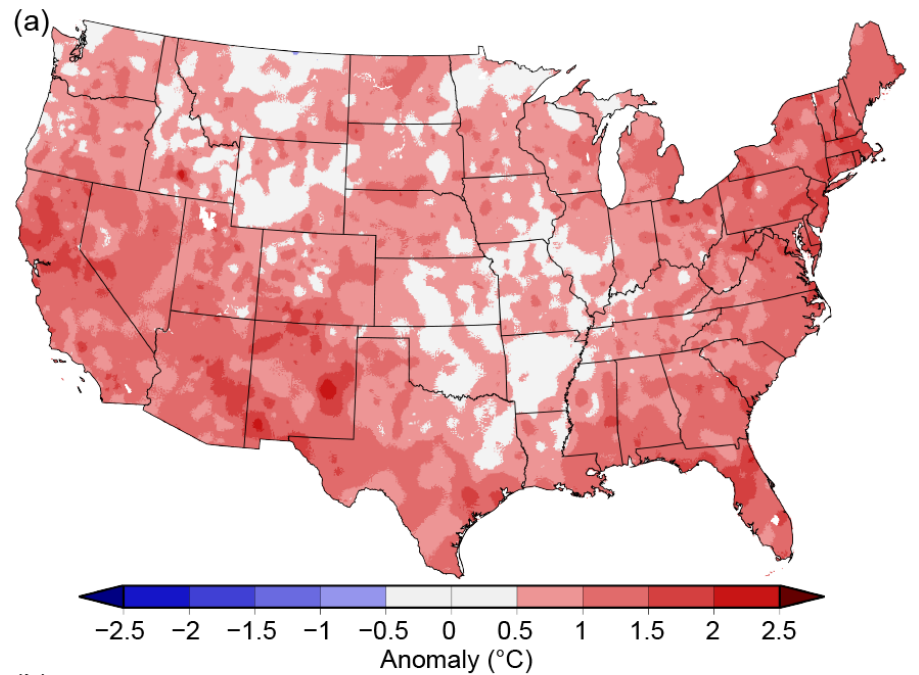

(b)

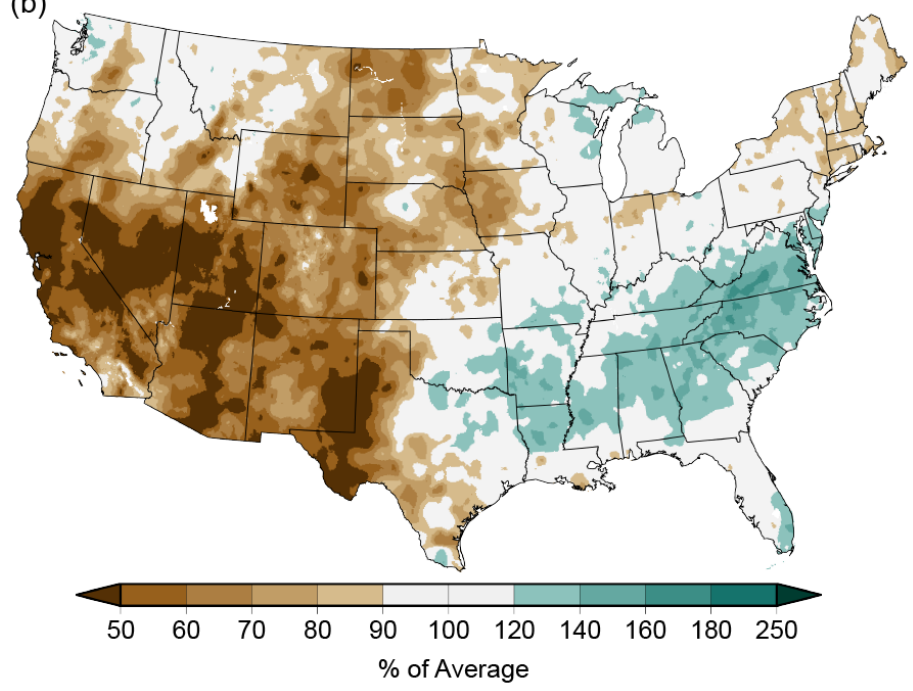

Fig. 7.4. Annual (a) average temperature anomalies $\left({ }^{\circ} \mathrm{C}\right)$ and (b) total precipitation (\% of average) in the CONUS for 2020 (1981-2010 base period). (Source: NOAA/NCEI.)
The annual temperature for Alaska over the 96-year record is increasing at an average rate of $0.17^{\circ} \mathrm{C}$ decade $^{-1}\left(0.50^{\circ} \mathrm{C}\right.$ decade $^{-1}$ since 1970$)$.

Average precipitation across the CONUS totaled $769 \mathrm{~mm}$, which was $98 \%$ of the 19812010 average (Fig. 7.3b). Overall, the annual precipitation total has been increasing at an average rate of $5 \mathrm{~mm}$ decade $^{-1}\left(4 \mathrm{~mm}_{\text {decade }}{ }^{-1}\right.$ since 1970).

\section{(I) TEMPERATURE}

The winter (December-February) 2019/20 CONUS temperature was $1.4^{\circ} \mathrm{C}$ above average and was sixth warmest on record. Above-average warmth was present from coast-to-coast with near-record temperatures observed from portions of the Ohio Valley to New England. The CONUS spring (March-May) temperature was $0.5^{\circ} \mathrm{C}$ above average, ranking in the highest third of the record. Above-average temperatures were observed across the West, South, Great Lakes, and along the East Coast, with Florida experiencing its second-warmest spring on record. Near-average spring temperatures spanned from the Northern Rockies and Plains to the Tennessee Valley, with pockets of below-average temperatures observed across portions of the northern tier. The summer (June-August) CONUS temperature was $0.9^{\circ} \mathrm{C}$ above average, the fourth highest in the 126-year record. Arizona in the West and

Connecticut, Massachusetts, and Rhode Island in the East each had their warmest summer on record. Below-average temperatures were observed in portions of the lower Mississippi Valley. The autumn (September-November) CONUS temperature was $0.8^{\circ} \mathrm{C}$ above average, the 11th warmest on record. Above-average temperatures were present across much of the western, southern, and eastern United States. California and Arizona in the West and Florida in the Southeast were each 
record warm. The central United States experienced near-average temperatures with small areas of below-average temperatures spread through the regions.

\section{(II) PRECIPITATION}

The primary weather pattern for 2020 can be characterized by a ridge of high pressure that dominated the western United States and a trough of low pressure across the East. This pattern brought warm, dry air to much of the West throughout the year, while an active storm track impacted the weather from the lower Mississippi Valley to the Mid-Atlantic. North Carolina and Virginia had their second- and third-wettest year on record, respectively. Conversely, Nevada and Utah each had their driest year on record, with five other western states ranking 2020 among their five driest years (Fig. 7.4b). The absence of the North American Monsoon during 2020 contributed to the lack of precipitation received across the western United States.

Winter precipitation across the CONUS was 114\% of average and ranked in the wettest third of the historical record. Above-average precipitation fell across much of the Great Lakes, central Plains, and Southeast. Precipitation totals across Alabama and Georgia were second highest on record during this three-month period. Below-average precipitation occurred across parts of the West, Gulf Coast, northern Rockies, and Plains. Spring 2020 precipitation was 105\% of average and ranked in the wettest third of the record. Above-average precipitation occurred across portions of the West Coast, Southern Plains, Great Lakes, Ohio Valley, and Southeast. Precipitation was below average across parts of the Pacific Northwest, central Rockies, and northern Plains. Summer precipitation was $95 \%$ of average across the CONUS, with above-average wetness occurring across the Great Lakes, the middle and lower Mississippi River Valley, and the Mid-Atlantic. Conditions were dry across much of the West, Central Plains, and Northeast. Precipitation totals for Arizona and New Mexico were the lowest and second lowest on record, respectively. The autumn CONUS precipitation total was $87 \%$ of average. Above-average precipitation extended from the Gulf of Mexico into the Mid-Atlantic and across parts of the Deep South, Great Lakes, and Northwest. Drier-than-average conditions were present across much of the West, Northern and Central Plains, as well as parts of the Northeast. Precipitation across Arizona was record low for the autumn season, while in Virginia it was fourth lowest.

As 2020 progressed, both the CONUS drought footprint and intensity steadily grew. Minimum drought coverage for the year was $9.6 \%$ in mid-February, and the maximum extent was nearly $50 \%$ near the end of December. Drought early in the year was primarily confined to portions of the West and Texas. Over the first 3 months of the year, drought expanded across the West and also emerged in Florida. Above-average temperatures across the western United States exacerbated drought intensity and extent moving into the summer months. Flash drought, or the rapid onset of drought, developed across New England during the late summer and autumn as the region experienced below-average precipitation and record to near-record temperatures. At the peak of the drought coverage in December, more than 22\% of the CONUS experienced extreme and exceptional drought-the two worst categories-from the West to the Northern Plains.

\section{(III) NOTABLE EVENTS AND IMPACTS}

There were 22 weather and climate events across the United States during 2020 with losses each exceeding $\$ 1$ billion (U.S. dollars): seven tropical cyclone events, 13 severe storm events, one drought, and one major wildfire event (Fig. 7.5). This shatters the previous annual record of 16 events that occurred in both 2011 and 2017. The year’s loss total of \$95 billion (U.S. dollars) was the fourth-highest cost on record. The most costly events of the year include Hurricane Laura (see Sidebar 4.1 for details), the Western Wildfires, and the Midwest Derecho, which, together, accounted for nearly half of the U.S. cost total during 2020. The Western Wildfires consumed almost 4.2 million ha from California to Colorado and was the largest area consumed across the CONUS since at least 2000. The Midwest Derecho damaged infrastructure and crops from South 


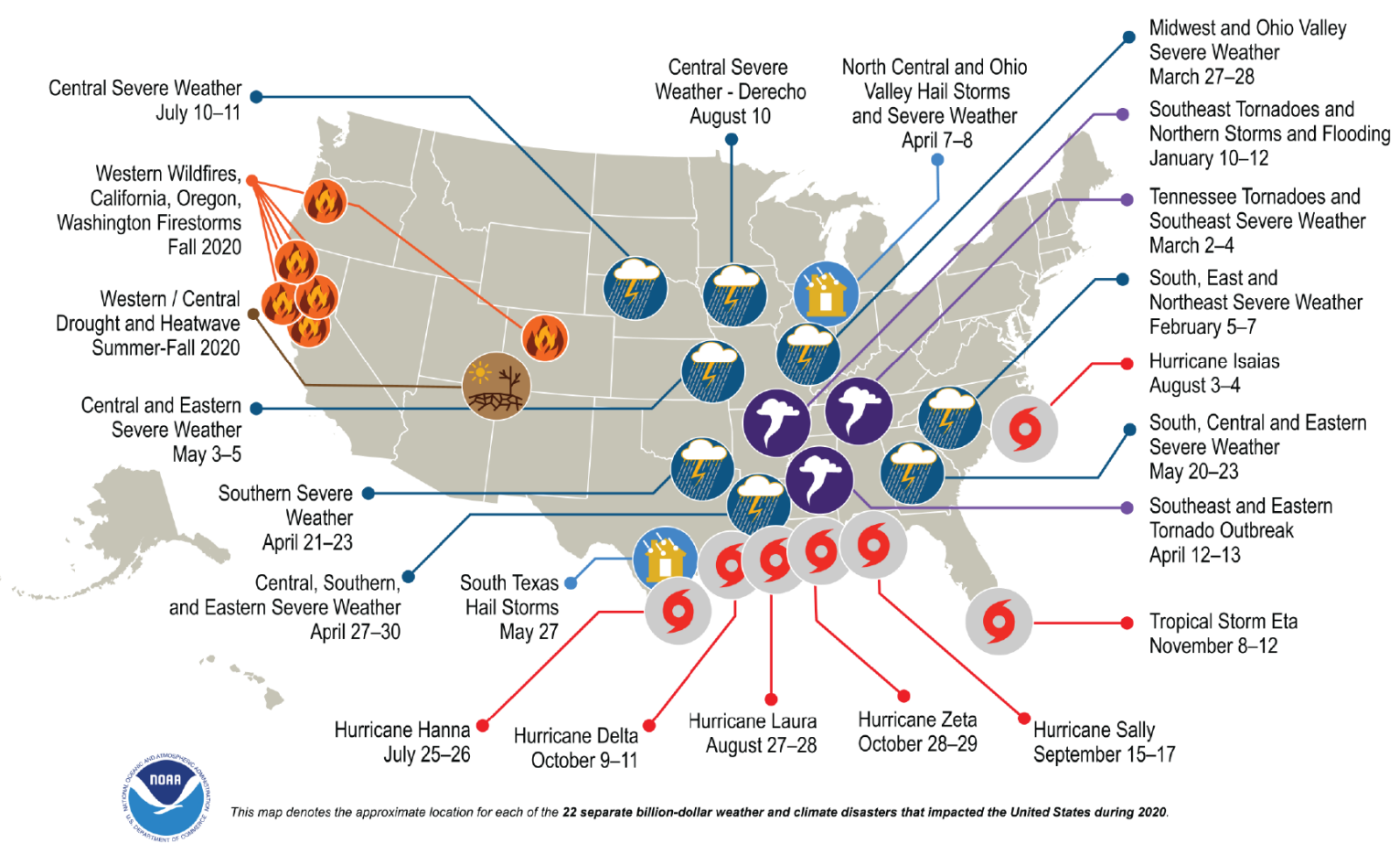

Fig. 7.5. Map depicting date, approximate location, and type of the 22 weather and climate disasters in the United States in 2020, with losses for each exceeding $\$ 1$ billion (U.S. dollars). (Source: NOAA/NCEI.)

Dakota to Ohio with the most damage occurring across Iowa. The total cost of U.S. billion-dollar disasters over the last five years (2016-20) exceeds a record $\$ 600$ billion (U.S. dollars; Smith 2020).

Record- to near-record sea surface temperatures across parts of the central Pacific Ocean contributed to the warmest year on record for both Kahului and Hilo, Hawaii, for 2020.

Preliminary reports for 2020 indicate that there were 1075 tornadoes across the CONUS. This was slightly below the 1991-2010 annual average of 1251 tornadoes. This included the 12-13 April tornado outbreak that produced 140 tornadoes from Texas to Maryland and 32 related fatalities. This was the deadliest tornado outbreak since April 2014.

\section{3) Mexico一R. Pascual Ramírez}

Temperatures across Mexico were above average during most of 2020, with the annual national mean temperature of $22.4^{\circ} \mathrm{C}$ tying with 2017 and 2019 as the warmest year on record. (Fig. 7.6). The 2020 precipitation total for Mexico was near average at $97 \%$ of normal. Most of the country, with the exception of the Yucatan Peninsula, the northeastern parts of the country, and the coast of Jalisco, had below-average rainfall for the year (Fig. 7.7b). Above-average precipitation on the Yucatan Peninsula was associated with tropical cyclones that impacted the region.

\section{(I) TEMPERATURE}

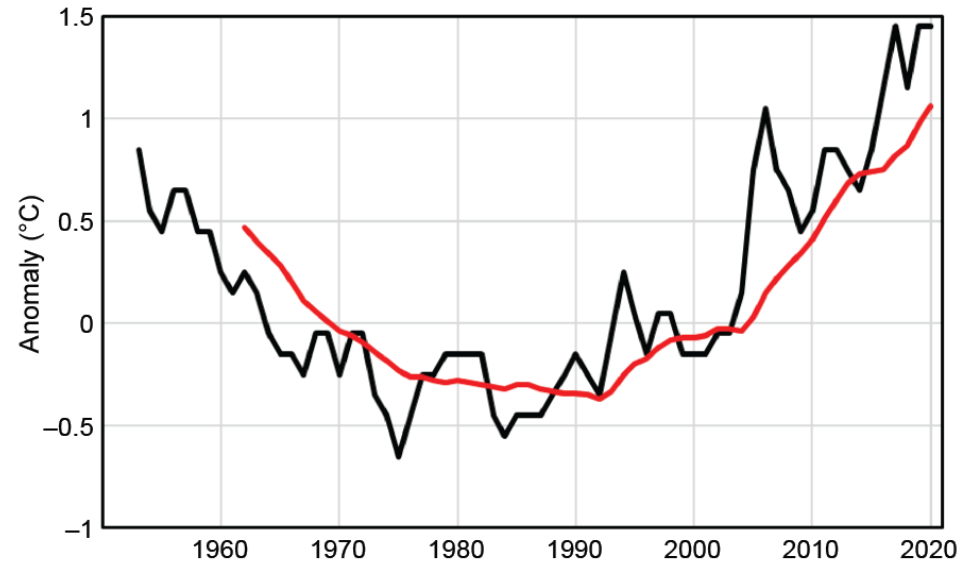

Fig. 7.6. Annual (a) mean temperature anomalies $\left({ }^{\circ} \mathrm{C}\right.$, black line; 1981-2010 base period) and (b) precipitation anomalies for Mexico. Red line depicts the lagged 10-year running mean. (Source: National Meteorological Service for Mexico.)

The 2020 national mean temperature was $1.5^{\circ} \mathrm{C}$ above the 1981-2010 average (Fig. 7.6). In addition to tying with 2017 and 2019 for the warmest year since temperature records began in 1953, this marked the 16th consecutive year with the annual average temperature at least nominally above average. The months of January through November were all warmer than average, with 
March, April, May, July, and November each record warm for their respective month. Seasonally, winter (January-March) ranked among the five warmest such periods on record. The summer period of July-September was the second warmest on record, behind 2019.

The 2020 mean temperature was above average across much of the country, with a few locations across the north, northwest, northern Baja California, and parts of the central and South Pacific that experienced below-average annual temperatures (Fig. 7.7a). Two states (Puebla and Yucatan) had their warmest year on record, and 10 had their second-warmest year on record. No state had a below-average annual temperature.

(a)



(b)

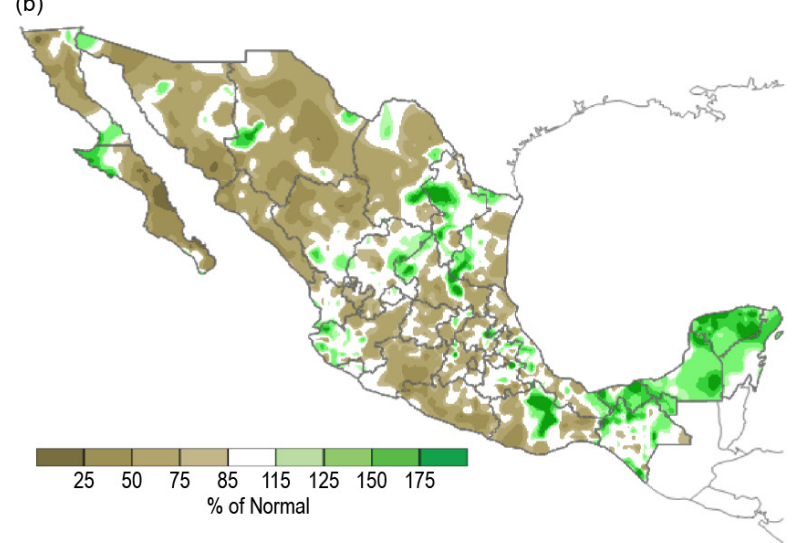

Fig. 7.7. 2020 annual mean (a) temperature anomalies $\left({ }^{\circ} \mathrm{C}\right)$ and $(\mathrm{b})$ precipitation anomalies (\% of normal) over Mexico (1981-2010 base period). (Source: National Meteorological Service of Mexico.)

\section{(II) PRECIPITATION}

Rainfall distribution varied regionally (Fig. 7.7b), with above-normal precipitation across southern areas, especially notable in the Yucatan Peninsula where the state of Yucatan observed its wettest year on record. Other regions with above-average rainfall included the northeast, specifically in central Nuevo León and southwestern Tamaulipas, along with small areas across the central-west region. The rest of the country had below-average precipitation, with the greatest deficits in the north and northwest states and states along the South Pacific coast.

With no impact from tropical cyclones on the Mexican Pacific side and a late onset and weak North American Monsoon, dryness and drought conditions were a constant concern throughout the year for the northwest, central-west, and southern Pacific states. In contrast, southern states and the Yucatan Peninsula received beneficial rainfall between June and October from Tropical Storms Cristobal and Gamma, along with Hurricanes Hanna, Delta, and Zeta.

Climatologically, September is the rainiest month of the year, contributing $18.4 \%$ of the annual rainfall. September 2020 was indeed the rainiest month of the year, but contributed a slightly lesser percentage of the annual rainfall (17.7\%). One reason for the below-average amount could be, as noted above, the lack of rainfall from reduced tropical cyclone activity near the country typically has occurred in September in past years. Climatologically, March is the driest month of the year, contributing $1.8 \%$ to the annual rainfall. However, in 2020, April, which typically contributes $2.5 \%$ of the annual rainfall, was the driest month of the year, contributing only $1.9 \%$ of the total annual rainfall.

\section{(III) NOTABLE EVENTS AND IMPACTS}

Five tropical cyclones affected Mexico during 2020, all from the Caribbean or the Atlantic basin (see section $4 \mathrm{~g} 2$ for details), with no tropical cyclones affecting Mexico from the Pacific side (see section 4g3). Five storms is near the long-term average. In 2005, seven tropical cyclones affected the country-the highest number on record. 
Tropical Storm Cristobal, the first tropical cyclone to affect the country during 2020, brought significant rainfall to southern Mexico and the Yucatan Peninsula, causing flooding over the Yucatan Peninsula during 1-4 June. Hurricane Hanna impacted northeastern Mexico on 26-27 July, and Tropical Storm Gamma and Hurricanes Delta and Zeta tracked over the Yucatan Peninsula in October (see section $4 \mathrm{~g} 2$ for details).

Drought majorly impacted the northern states of Chihuahua and Sonora throughout the year. At the end of 2020, Mexico's federal government issued a Drought Disaster Declaration for both states. With the declaration, these states were given access to resources to mitigate their losses; most of the losses reported were on rain-fed crops and livestock.

\section{c. Central America and the Caribbean-A. Sánchez-Lugo, Ed.}

\section{1) Central America-J. A. Amador, H. G. Hidalgo, E. J. Alfaro, B. Calderón, and N. Mora}

For this region, nine stations from five countries were analyzed (see Fig. 7.8 for data and station list). The station distribution covers the relevant intraseasonal regimes of precipitation (Amador 1998; Magaña et al. 1999; Amador et al. 2016a,b), wind (Amador 2008), and temperature (Hidalgo et al. 2019) on the Caribbean and Pacific slopes of Central America (CA). Precipitation and temperature records for the stations analyzed and regional wind were provided either by CA National Weather Services (CA-NWS), NOAA, or the University of Costa Rica. Anomalies are reported using a 1981-2010 base period and were calculated using CA-NWS data. The methodologies used for all variables can be found in Amador et al. (2011).

\section{(I) TEMPERATURE}

The mean temperature (Tm) pentad frequency distributions in 2020, as well as the climatology, for the nine stations analyzed are shown in Fig. 7.8. During 2020, most stations had near- to coolerthan-normal conditions. The 2020 mean temperature for Liberia, Costa Rica (Tm7), was at least $3^{\circ} \mathrm{C}$ below average. Meanwhile, Puerto Barrios, Guatemala (Tm2), observed an annual temperature that was $2^{\circ} \mathrm{C}$ above average, the highest departure among the stations. Puerto Limón, Costa Rica (Tm4), had a below-average annual temperature with respect to its climatological normal, while Puerto San José, Guatemala (Tm9), observed an above-average temperature. Philip Goldson International Airport (Tm1) recorded slightly above-average annual temperature for 2020. A comparison between the climatology and the 2020 pentad distributions shows that seven of the nine stations presented different statistical distributions (exceptions were Puerto Lempira [Tm3] and David [Tm6]), suggesting that Tm was distributed significantly different from the climatology in 2020. Puerto Barrios (Tm2), Puerto Limón (Tm4), Tocumen International Airport (Tm5), Liberia (Tm7), Choluteca (Tm8), and Puerto San José (Tm9) showed significantly different means than climatology.

\section{(II) PRECIPITATION}

The accumulated pentad precipitation (P) time series for the nine stations in Central America are presented in Fig. 7.8. Puerto Barrios (P2), Puerto Lempira (P3), Puerto Limón (P4), and Tocumen International Airport (P5) showed different 2020 statistical distributions from that of the base period, while the remainder of the stations showed no significant differences from climatology. Puerto Limón observed drier-than-normal conditions during most of the year, while Liberia (P7) was wetter than normal (after pentad 60, approximately mid-October), ending the year with a rainfall surplus. These conditions in Liberia and Limón are consistent with a characteristic teleconnection pattern associated with La Niña, the cold phase of the El Niño-Southern Oscillation (ENSO; Hidalgo et al. 2019). General wet conditions were also registered in Puerto Barrios and Puerto Lempira after pentad 60. For Tocumen International Airport (P5) and David (P6), both in Panamá, precipitation totals were near normal. Puerto San José (P9) began the year with abovenormal rainfall, but below-normal precipitation rates were registered around mid-September and 
the year ended drier than normal. Philip Goldson International Airport (P1) and Choluteca (P8) showed the opposite pattern: the year began drier than average but increased precipitation rates around pentad 60 led to wetter-than-normal conditions by the end of 2020.

Low-level circulation anomalies in the westernmost Caribbean Sea and Pacific regions show slightly weaker winds in the trade wind system during July (vectors in Fig. 7.8), but the relationship of precipitation distribution associated with the emergence of La Niña during summer did not follow the normal pattern (Amador 2008). During a typical La Niña episode, below-normal winds are usually associated with slightly below-normal precipitation along the Caribbean slopes and above-normal precipitation on the Pacific slopes during summer. In 2020, only Puerto Limón showed that expected behavior with below-normal precipitation. The anomalously active hurricane season may be responsible for this anomaly (see Sidebar 7.1).

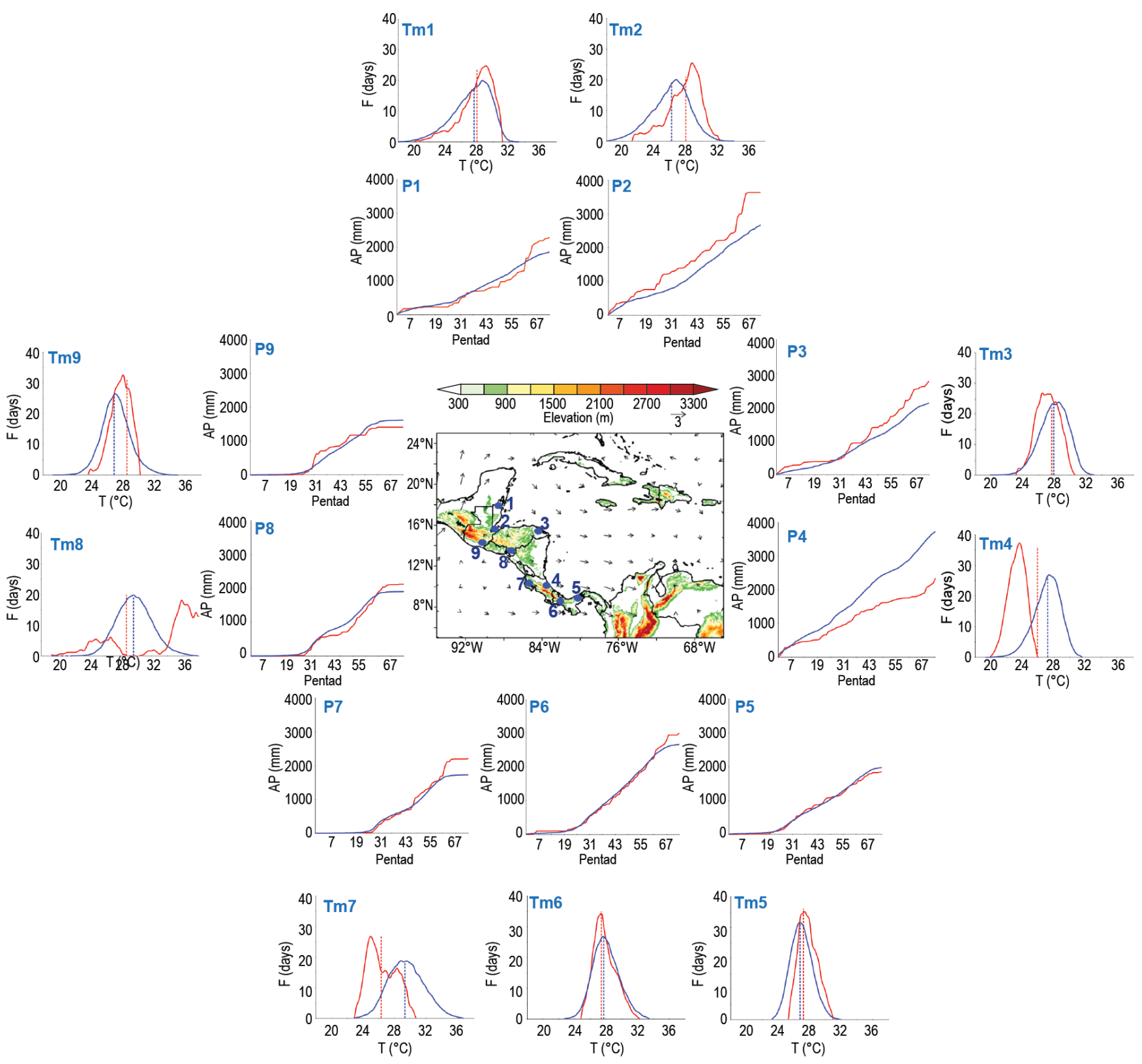

Fig. 7.8. Mean surface temperature $\left(\mathrm{Tm} ;{ }^{\circ} \mathrm{C}\right)$ frequency $(\mathrm{F}$; days), and accumulated pentad precipitation $(\mathrm{P} ; \mathrm{mm})$ time series are shown for nine stations (blue dots) in Central America: (1) Philip Goldson International Airport, Belize; (2) Puerto Barrios, Guatemala; (3) Puerto Lempira, Honduras; (4) Puerto Limón, Costa Rica; (5) Tocumen International Airport, Panamá; (6) David, Panamá; (7) Liberia, Costa Rica; (8) Choluteca, Honduras; and (9) Puerto San José, Guatemala. The blue solid line represents the 1981-2010 average values and the red solid line shows 2020 values. Vertical dashed lines show the mean temperature for 2020 (red) and the 1981-2010 period (blue). Vectors indicate July wind anomalies at $925 \mathrm{hPa}$ (1981-2010 base period). Shading depicts regional elevation (m). (Sources: NOAA/NCEI and CA-NWS.) 


\section{(III) NOTABLE EVENTS AND IMPACTS}

In the eastern tropical Pacific Ocean, Tropical Storm Amanda made landfall along the GuatemalaEl Salvador border on 31 May, becoming the only named storm of the season to make landfall in that region. From the remnants of this storm, Tropical Storm Cristóbal (1-12 June) formed in the Gulf of Campeche (Mexico), affecting northern Central America and causing more than 30 fatalities in the region. In the Caribbean basin, tropical cyclone activity during 2020 was extremely active with 10 named storms, five hurricanes, and three major hurricanes (Category 3 or higher on the SaffirSimpson Hurricane Wind Scale). The three major hurricanes were Delta (5-10 October, Category 4); Eta (31 October-13 November, Category 4, landfall over Nicaragua and Honduras on 3-5 November); and Iota (13-18 November, Category 4). Eta and Iota made landfall near the same location between the northeastern coast of Nicaragua and southern coast of Honduras as major hurricanes and were associated with severe impacts over the isthmus. As seen in Table 7.1, the season resulted in a total of 237 fatalities due to hydrometeorological events and 16 deaths by lightning strikes.

\begin{tabular}{|c|c|c|c|c|c|}
\hline \multicolumn{6}{|c|}{$\begin{array}{l}\text { Table 7.1. Number of fatalities in several Central American countries due to tropical storms } \\
\text { and lightning strikes. Some countries reported fatalities for two storms. (Data sources: Central } \\
\text { American National Weather Services, National Emergency Committees communications and } \\
\text { regional newspapers.) }\end{array}$} \\
\hline Country & Amanda & Christóbal & Eta & lota & $\begin{array}{l}\text { Lightning } \\
\text { Strikes }\end{array}$ \\
\hline Panamá & - & - & 19 & - & 3 \\
\hline Costa Rica & - & - & 2 & - & 1 \\
\hline Nicaragua & - & - & 2 & 16 & 7 \\
\hline El Salvador & 27 & & 1 & 1 & 1 \\
\hline Honduras & 4 & & 77 & 22 & 1 \\
\hline Guatemala & 2 & 3 & 53 & 8 & 3 \\
\hline Totals & 33 & 3 & 154 & 47 & 16 \\
\hline
\end{tabular}

2) Caribbean-T. S. Stephenson, M. A. Taylor, A. R. Trotman, C. J. Van Meerbeeck, K. A. Stephenson, L.A. Clarke, G. Tamar, J. M. Spence, Annie C. Joseph, and J. D. Campbell

\section{(I) TEMPERATURE}

In 2020, the Caribbean experienced above-average and record temperatures, with annual mean temperatures anomalies ranging from $+0.25^{\circ} \mathrm{C}$ to $+2.50^{\circ} \mathrm{C}$ above the $1981-2010$ average. Anomalies were highest over the northwestern Caribbean (Jamaica, Cuba, and the Bahamas) and over Trinidad and Barbados in the east (Fig. 7.9a). The annual average temperature anomaly over the domain was approximately $0.85^{\circ} \mathrm{C}$ above average, the second highest since the start of the record in 1891 (Fig. 7.10a). Region-wide, the month of September was particularly hot, with 26 Caribbean locations (out of 28 with an up-to-date historical record of daily maximum temperature spanning at least 30 years) recording an above-average number of hot days-that is, days with a maximum temperature exceeding the 90th percentile as calculated from a 1985-2014 climatological period-between 8 and 28 hot days. Annual average maximum temperatures were record high for Freeport, The Bahamas $\left(29.9^{\circ} \mathrm{C}\right.$; since 1971), for Canefield, Dominica $\left(31.9^{\circ} \mathrm{C}\right.$; since 1982$)$, and for Crown Point, Tobago, Trinidad and Tobago $\left(31.3^{\circ} \mathrm{C}\right.$; since 1971$)$, while Lamentin, Martinique $\left(31.3^{\circ} \mathrm{C}\right)$, and Sint Maarten $\left(31.1^{\circ} \mathrm{C}\right)$ reported their second-highest maximum temperatures since 1971 and 1983, respectively, and Hewannora, Saint Lucia $\left(31.0^{\circ} \mathrm{C}\right)$, reported its third highest since 1979. Record high monthly average maximum temperatures for any month were observed in Aruba $\left(34.3^{\circ} \mathrm{C}\right.$ in September), Martinique $\left(32.9^{\circ} \mathrm{C}\right.$ in September in Lamentin), and Saint Lucia $\left(32.4^{\circ} \mathrm{C}\right.$ in September at Hewanorra), since 1985, 1975, and 1986, respectively. Record daily maximum temperatures were observed in September relative to the entire historical records for the countries 

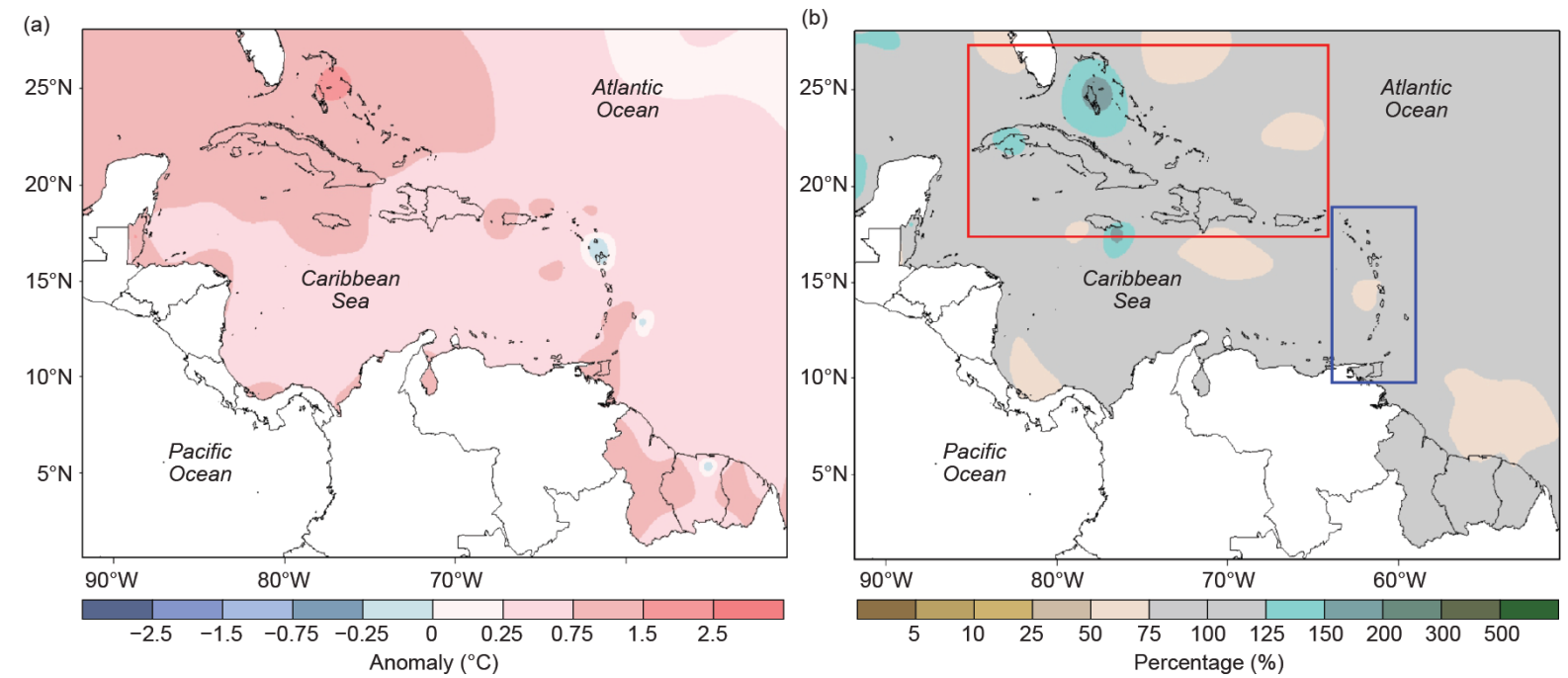

Fig. 7.9. Annual (a) mean temperature anomalies $\left({ }^{\circ} \mathrm{C}\right)$ and $(\mathrm{b})$ total precipitation anomalies (\% of normal) relative to $1981-$ 2010. Red (Blue) rectangle encloses northern (eastern) Caribbean. (Source: Caribbean Climate Outlook Forum [CariCOF] and the Caribbean Institute for Meteorology and Hydrology.)

of Dominica $\left(35.7^{\circ} \mathrm{C}\right.$ at Canefield Airport on 15 September) and Grenada $\left(34.0^{\circ} \mathrm{C}\right.$ at Point Salines on 16 September), with records starting in 1975 and 1986, respectively.

\section{(II) PRECIPITATION}

In 2020, the Caribbean experienced near-normal to slightly above-normal daily precipitation, averaging $0.28 \mathrm{~mm} \mathrm{day}^{-1}$ above the 1981-2010 normal (Fig. 7.10b). The eastern and northern Caribbean subdomains had anomalies of $+0.18 \mathrm{~mm}_{\text {day }}{ }^{-1}$ and $+0.09 \mathrm{~mm} \mathrm{day}^{-1}$, respectively, according to Global Precipitation Climatology Centre (GPCC) satellite analyses. Station data further suggest that the northern countries over the eastern Caribbean (e.g., Anguilla, Sint Maarten, Guadeloupe, St. Kitts, and St. Thomas) experienced normal rainfall, with drier-than-normal conditions observed over some southern countries (e.g., St. Vincent, St. Lucia, and Martinique). Some northern Caribbean locations (e.g., The Bahamas, western Cuba, and eastern Jamaica) showed above-normal precipitation compared to the rest of the region (Fig. 7.9b), likely linked to storms and hurricanes traversing (near) these locations. New Providence, Bahamas (2206.3 mm), and Port-au-Prince, Haiti (1715.6 mm), each recorded their wettest year on record since 1970 and 1982, respectively when observations commenced. Conversely, Monte Cristi, Dominican Republic ( $265.2 \mathrm{~mm})$, recorded its driest year on record since 1972 when its record began.
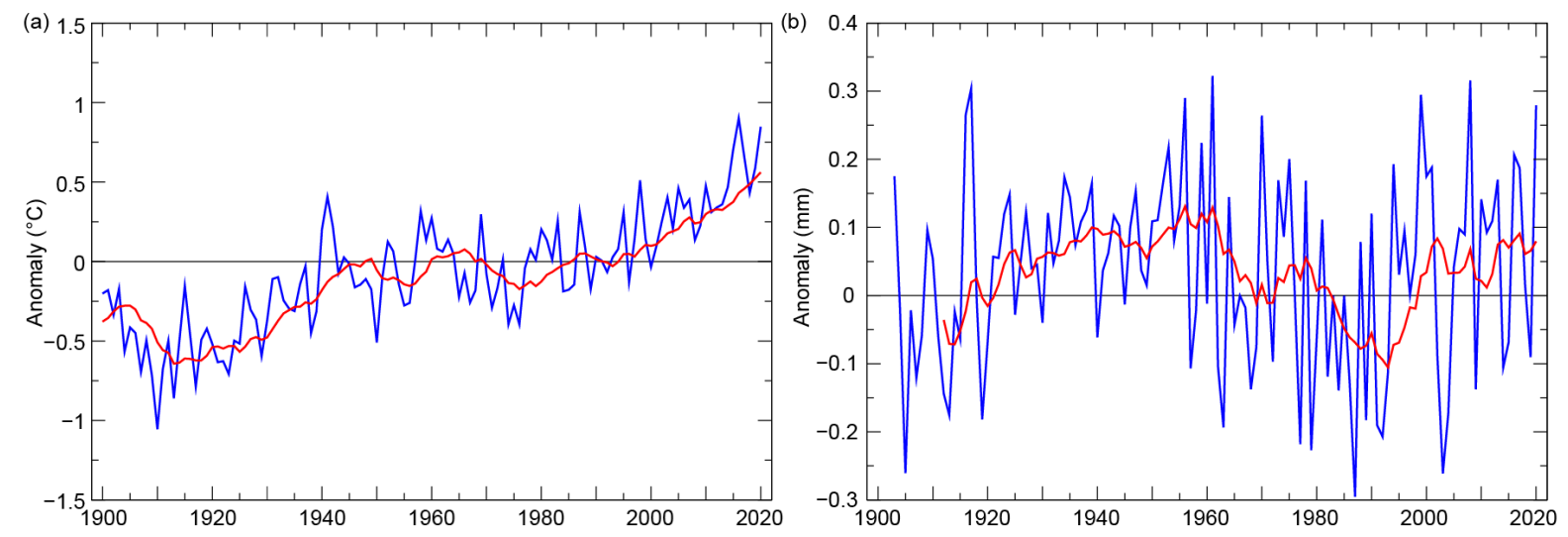

Fig. 7.10. Annual average (a) temperature anomalies $\left({ }^{\circ} \mathrm{C}\right)$ and $(\mathrm{b})$ daily rainfall anomalies $\left(\mathrm{mm}\right.$ day $\left.{ }^{-1}\right)$ for the Caribbean $\left(9^{\circ}-27^{\circ} \mathrm{N}\right.$; $58^{\circ}-90^{\circ} \mathrm{W}$ ) for $1903-2020$ relative to the $1981-2010$ average. The red line is the 10 -year running mean. (Sources: NOAA/NCEI and GPCC from the KNMI Climate Explorer.) 
The transition from ENSO-neutral conditions in January to La Niña by August was an important driver for how rainfall patterns emerged over the region. La Niña conditions are generally associated with above-normal late season Caribbean rainfall (e.g., Taylor et al. 2002). Initially, drier conditions were observed over most of the region during the first 6 months of the year, persisting from October 2019. The exception was over eastern Dominican Republic and southward to Dominica where very wet conditions were observed during January-March. October-December was characterized by recurrent extreme rainfall related to La Niña conditions and above-average storm activity, causing flooding across many Caribbean countries.

\section{(III) NOTABLE EVENTS AND IMPACTS}

A Sahara dust event in June 2020 impacted the Caribbean. The haze was visible in a number of islands with Guadeloupe, Martinique, and Puerto Rico classifying air quality levels as hazardous. Puerto Rico recorded concentrations of PM10 (particulate matter that can penetrate into the lungs causing respiratory problems and disease) higher than $500 \mu \mathrm{g} \mathrm{m}^{-3}$, the highest observed in the last 20 years of data (WMO 2020).

Hurricane Isaias impacted the Caribbean from 28 July to 1 August, bringing heavy rains to the eastern Caribbean, which led to flash floods, landslides, and damage to electricity, infrastructure, and water supply in Puerto Rico, along with two reported deaths and widespread flooding in the Dominican Republic. The impact of Hurricane Isaias to The Bahamas was pronounced, including damage to homes even as the country was still recovering from the losses from Hurricane Dorian in 2019. Some residents were left homeless in Cuba due to severe flooding, and Haiti experienced damage to crops and homes.

In August, Hurricane Laura impacted the Caribbean as a tropical storm and caused 24 fatalities. The impact was particularly devastating in Haiti where flash flooding and landslides in Port-au-Prince killed at least 21 people. Laura also caused three deaths in the Dominican Republic. Both Jamaica and Cuba experienced landslides, flooding, and damage to critical infrastructure. See section $4 \mathrm{~g} 2$ and Sidebar 4.1 for more details about Hurricane Laura.

An extended drought impacted the insular Caribbean from October 2019 to mid-2020, causing water scarcity, bush fires, and agricultural losses. In St. Vincent and the Grenadines, the 2020 drought was considered the worst in 50 years (Nurse 2020). 


\section{Sidebar 7.1: Record-breaking hurricane landfalls in Central America-S. DIOUF, S. FUHRMAN,}

W. M. THIAW, AND F. ARGEÑALSO

In less than 1 month, Central America was impacted by two powerful hurricanes between 1 and 18 November 2020: Category 4 Hurricanes Eta and lota. These two close events caused massive devastation and destruction in the region, leaving little respite to the population.

\section{Hurricane Eta}

Tropical Storm Eta became the 28th named storm of the 2020 Atlantic Hurricane season (see section 4g2) on 1 November, tying the record number of storms set in 2005. For the second time since the start of the storm naming convention in 1950, the Greek alphabet was used to name the tropical system, because the designated list of 21 names for the 2020 season was exhausted. This was also the first time that the name Eta was used in the Atlantic basin.

After remaining a tropical storm for several hours, Eta intensified explosively on 2 November to reach peak intensity as a strong Category 4 hurricane, with maximum sustained winds of $240 \mathrm{~km} \mathrm{~h}^{-1}$ and its lowest recorded pressure of $923 \mathrm{hPa}$. Eta was the 12th hurricane and the fifth major hurricane of this Atlantic hurricane season.

After approaching the northeastern Nicaragua coast, the eye of Hurricane Eta made an impactful landfall in Nicaragua, about $25 \mathrm{~km}$ south of Puerto Cabezas, on 3 November (Fig. SB7.1). The Puerto Cabezas airport measured sustained winds of $172 \mathrm{~km} \mathrm{~h}^{-1}$ and a gust of $217 \mathrm{~km} \mathrm{~h}^{-1}$ during a 2-hour period. Winds were so strong that they uprooted trees and ripped roofs from homes.

The storm drenched neighboring Honduras, where widespread flooding and landslides caused damage across the country. The Honduras emergency management agency reported the rescue of over 20 people and the displacement of at least 559 people due to significant flooding.

On 4 November, Hurricane Eta was downgraded to a tropical storm with sustained maximum winds of near $110 \mathrm{~km} \mathrm{~h}^{-1}$ and a minimum central pressure of $990 \mathrm{hPa}$. As it moved over land and entered eastern Honduras, it continued to weaken into a tropical depression by the evening, while still spreading very heavy rain. Many roads and bridges were destroyed or temporarily made inaccessible, and power lines were knocked down, leaving the population cut off from assistance. The impacts of the hurricane reached far beyond the areas directly hit by Eta. Storm totals in excess of $100 \mathrm{~mm}$ were measured as widely as David, Panama, and Belize City, Belize. Torrential rains led to severe flooding that occurred in the central and southern regions of Belize, affecting around 60,000 people.

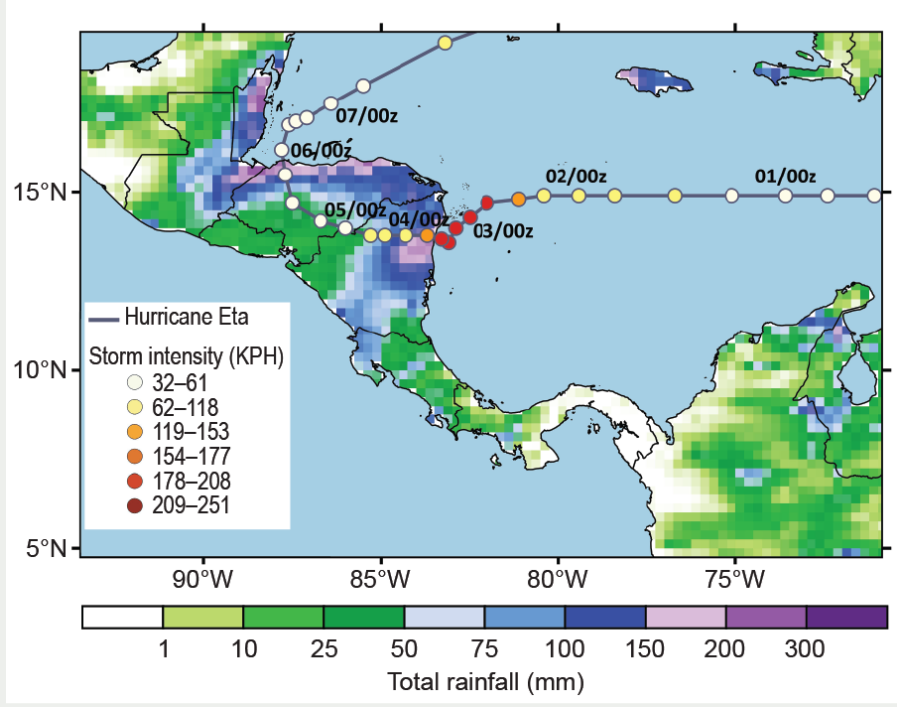

Fig. SB7.1. Hurricane Eta National Hurricane Center (NHC) best track overlaid with associated cumulative satellite estimated rainfall (mm; CMORPH) for 2-7 Nov 2020. (Source: NOAA/NCEP.)

The following day, Eta entered northeastern Guatemala. It generated accumulated precipitation totals of more than $200 \mathrm{~mm}$ in 24 hours, especially notable in northern Guatemala. The excessive rainfall led to a landslide that killed eight people and injured four others in the village of Quejà, San Cristobal Verapaz. In addition, 88 people disappeared in the Agua Caliente neighborhood. On 6 November, Eta's circulation turned northeastward over the Caribbean Sea and exited the region.

\section{Hurricane lota}

While residents were still coping with the aftermath of Hurricane Eta, another major storm was approaching, threatening to compound destruction and inflict additional damages for the same hard-hit areas in Central America.

On 14 November, Tropical Storm lota became the 30th named storm of the season. By 15 November, lota reached hurricane status as it approached Central America, becoming the 13th hurricane of this unusually busy hurricane season.

On 16 November, lota intensified into a Category 3 storm, becoming the sixth major hurricane of the season. For the first time on record, the Atlantic basin experienced two major hurricanes during the month of November. As the hurricane approached Central America, its pressure fell from $945 \mathrm{hPa}$ to 935 $\mathrm{hPa}$ in a little over an hour. Additionally, intense lightning was present in the southwestern quadrant of the eyewall, along with hail that is unusual for a tropical system. This contributed to the 
extraordinary characteristics of the hurricane. lota strengthened to become an extremely dangerous Category 4 storm, with maximum sustained winds reaching $260 \mathrm{~km} \mathrm{~h}^{-1}$ and its minimum central pressure estimated at $917 \mathrm{hPa}$.

On 17 November, lota made destructive landfall along the eastern coast of Nicaragua, notably near the town of Haulover situated south of Puerto Cabezas, which was soaked and lashed by Category 4 Eta earlier in the month. In Haulover, around 1750 residents, mostly indigenous people, were impacted by the devastating rains measured in excess of $150 \mathrm{~mm}$, according to NOAA's CPC Morphing Technique (CMORPH) estimates (Fig. SB7.2). lota was the strongest hurricane to impact Nicaragua on record.

A few hours later, lota was downgraded to a tropical storm, while still dropping very heavy rains on Nicaragua, with rivers overflowing and trees and electricity poles felled by unceasing winds. The storm degraded to a tropical depression as it headed into El Salvador on 18 November and finally dissipated a few hours later. For the second time in 2 weeks, Ramón Villeda Morales International Airport in Honduras was engulfed by floodwaters.

The widespread flooding from lota was exacerbated by the antecedent ground saturation after Hurricane Eta. Together, the two storms dumped an enormous amount of rain on a large part of the region. According to satellite rainfall estimates, more than $300 \mathrm{~mm}$ of rain fell over much of eastern Nicaragua, northern Honduras, parts of eastern Guatemala, and Belize. CMORPH climatology indicates about $100-200 \mathrm{~mm}$ of rain typically during the month of November in that region.

\section{Impacts}

According to the United Nations Office for the Coordination of Humanitarian Affairs, Eta and lota affected more than 7.3 million people in all Central American countries, especially Honduras, Nicaragua, and Guatemala. In Honduras, more than 2.9 million people were impacted by Hurricane Eta, and this number increased to 3.8 million after the passage of lota. The two hurricanes and their aftermaths claimed the lives of 98 people, destroyed more than 61,000 homes, and damaged more than 700 roads across Honduras. One month after lota, 95,000 people were still living in shelters. The Nicaraguan government estimated that damages and economic losses attributed to both events were $\$ 738$ million (US dollars; $6.2 \%$ of the Gross Domestic Product).

Relentless rainfall and winds from both hurricanes also resulted in decreased yield for the Segunda/Postrera agricultural season that typically starts with planting in August and September and concludes with harvest in December. According to the Ministry of Agriculture and Livestock of Honduras, more than 8000 ha of maize and more than 12,000 ha of beans were destroyed in 10 departments of Honduras. Banana, African palm, and sugar cane were also severely affected. In Nicaragua, bean crops, which account for $25 \%$ of the national production, significantly suffered from both storms, especially in the northern part of the country. In Guatemala, the Ministry of Agriculture, Livestock and Food estimated a total of 164,000 ha of crop areas suffered damage. The eastern part of the country, which is an important bean-producing area, lost $50 \%-60 \%$ of bean crops. These important agricultural losses, combined with the economic effects of the COVID-19 pandemic across Central America, led to a decline in annual income and worsened food insecurity for a large number of people in the region.



Fig. SB7.2. Hurricane lota NHC best track overlaid with associated cumulative satellite estimated rainfall ( $\mathrm{mm}$; CMORPH) for 16-18 Nov 2020. (Source: NOAA/NCEP.) 
d. South America-A. Sánchez-Lugo, Ed.

With the exception of northeastern Brazil and most of Colombia, most of South America had above-average temperatures during the year. The most notable maximum temperatures were reported in central South America and southwestern Brazil, where temperature anomalies were at least $+1.5^{\circ} \mathrm{C}$. Below-average minimum temperatures were observed in Colombia, northeastern Argentina, and eastern Brazil. During the year, wetter-than-normal conditions were observed in eastern Colombia and northern and northeastern Brazil. Below-average conditions were mainly observed in Chile, eastern Ecuador, northern Peru, eastern Bolivia, southern Brazil, and most of Uruguay, Paraguay, and northwestern Argentina. Anomalies in this section are all based on the 1981-2010 average, unless otherwise noted.

1) NORTHERN SOUTH AMERICA—J. J. Nieto and F. Costa

This section includes Colombia, Ecuador, Guyana, Suriname, and Venezuela.

\section{(I) TEMPERATURE}

Annual temperature departures of at least $+0.5^{\circ} \mathrm{C}$ above the $1981-2010$ average were observed across much of northern South America. Mean monthly temperatures were above normal for most of the year throughout the region despite a La Niña that developed and prevailed in the eastern tropical Pacific for much of the second half of 2020.

On the cool side, Colombia observed an annual maximum temperature anomaly of $-0.8^{\circ} \mathrm{C}$ below normal, and conversely, Venezuela had an annual maximum temperature anomaly of $+1.5^{\circ} \mathrm{C}$ above normal. During April, July, and October, several locations across Venezuela had a maximum temperature anomaly close to $+2.5^{\circ} \mathrm{C}$, while much of Ecuador had an annual maximum temperature anomaly of $+0.3^{\circ} \mathrm{C}$ (Fig. 7.11a). Most of northern South America observed annual minimum temperature anomalies between $+0.5^{\circ} \mathrm{C}$ and $+1.5^{\circ} \mathrm{C}$, although some Andean regions of southern Ecuador and central Colombia reported below-normal minimum temperature anomalies of about $-0.5^{\circ} \mathrm{C}$ (Fig. 7.11b).

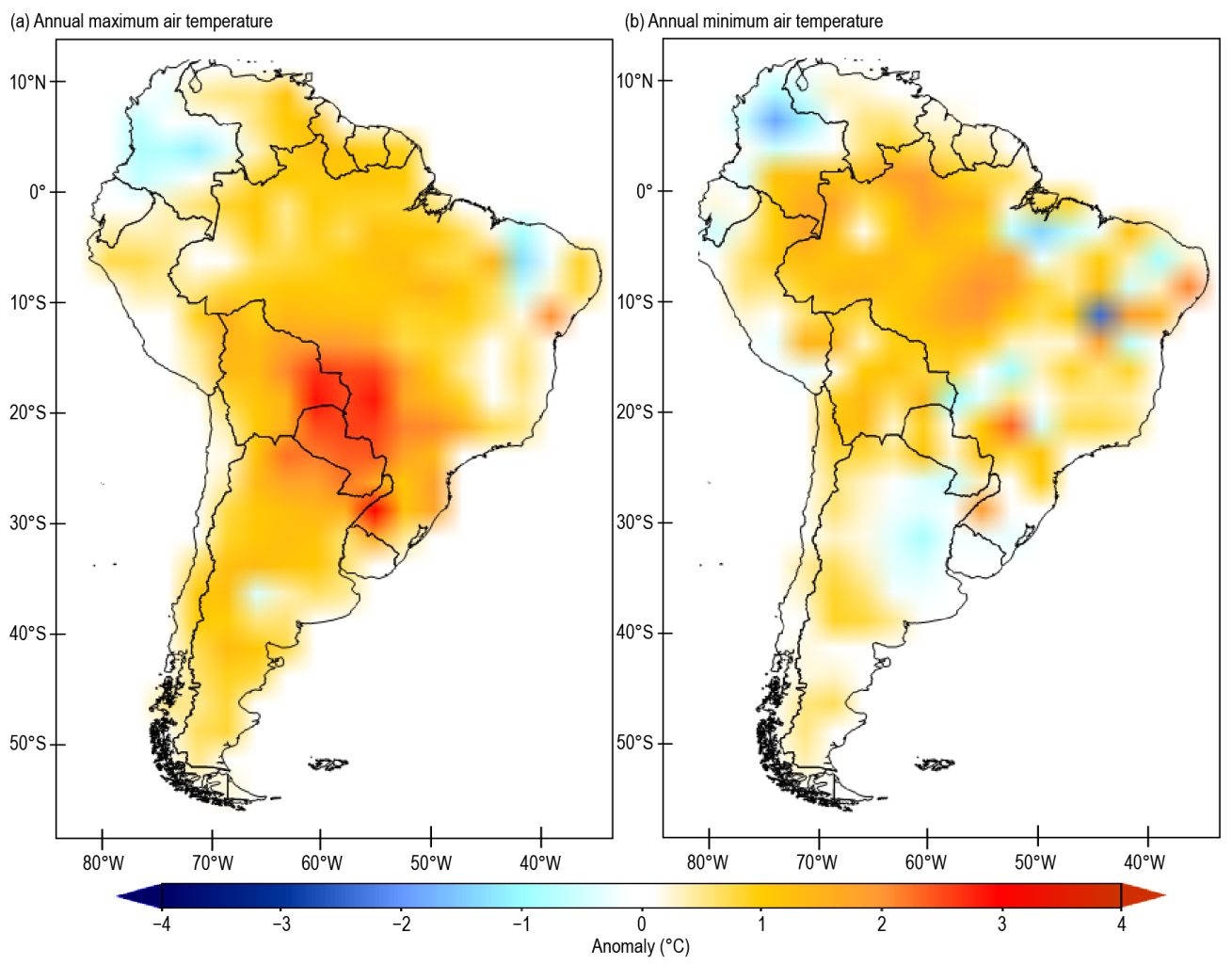

Fig. 7.11. Annual (a) maximum and (b) minimum temperature anomalies ( ${ }^{\circ} \mathrm{C} ; 1981-2010$ base period). (Source: Data from NMHSs of Argentina, Colombia, Chile, Brazil, Ecuador, Paraguay, Peru, Suriname, and Venezuela; processed by CIIFEN.) 


\section{(II) PRECIPITATION}

Parts of northern South America, particularly Venezuela, had 50\%-60\% above-normal rainfall during September and October. Rainfall in central and eastern Colombia was 20\%-30\% above normal during October and November. Above-normal rainfall in the north of northern South America was associated with two major hurricanes: Eta and Iota (see Sidebar 7.1 for details), in addition to the effects of La Niña, which is usually associated with increased rainfall in the region. Western (coastal region) and eastern (Amazon region) Ecuador reported $20 \%-40 \%$ and $60 \%-80 \%$, respectively, belownormal rainfall for the year, with the second half of the year contributing to much of the deficit. The northern Andean region of Ecuador had 30\%-40\% above-normal annual rainfall, with September-November particularly wet (Fig. 7.12).

\section{(III) NOTABLE EVENTS AND IMPACTS}

Intense rainfall occurred during August, with a cumulative $446 \mathrm{~mm}$ recorded at the Rancho Grande $\left(10.3^{\circ} \mathrm{N}, 67.6^{\circ} \mathrm{W}\right)$ hydrometeorological station (62\% above its climatological average), contributing to a landslide in the upper basin of the state of Aragua in northern Venezuela in September. The detached mass was deposited on a nearby populated area. Tributaries of the El Limón River also suddenly overflowed. As a result of this event, more than 1400 people were affected, with eight serious injuries reported. Additionally, more than 400 homes, 120 commercial properties, and dozens of vehicles were damaged, and electric and water system outages were reported.

Also in the state of Aragua, heavy rainfall in October caused flashfloods. During this event, a 1-hour precipitation total of $85 \mathrm{~mm}$ was recorded. As a result of the rains, increased flows of the Turmero, Madre Vieja, Caño Colorado, El Manguito, Corral de Piedra, and La Trinidad Rivers were observed. Nearly 20,000 people were affected, including one reported fatality, and nearly 5000 structures and vehicles were damaged or destroyed.

In late October and early November, floods were reported over a 2-week period in Guyana due to heavy rainfall, affecting more than 1600 households across five regions. In Georgetown, where the highest level of rainfall was observed, during 3-4 November, the accumulated total was $120.3 \mathrm{~mm}$. The rains, combined with high tides, affected the infrastructure of maritime and river defenses, which protect people, assets, livelihood, and the environment.

On 16 November, the passage of Hurricane Iota was recorded in the San Andres and Providencia Department, two island groups in the Caribbean Sea about $775 \mathrm{~km}$ northwest of mainland Colombia. Within 4 hours, Iota intensified from a Category 3 to a powerful Category 4 storm, with maximum wind speeds of more than $230 \mathrm{~km} \mathrm{~h}^{-1}$. The impacts of Iota in the region included downed power lines, damaged and destroyed homes, uprooted trees, floods, and strong winds (see Sidebar 7.1 and section $4 \mathrm{~g} 2$ for more details about the storm).

During the first 2 weeks of November, heavy rain fell in the Bogotá region of Colombia, exceeding $190 \mathrm{~mm}$. Resulting landslides affected the road infrastructure of the region and, consequently, 
the traffic. The above-normal rainfall was associated with the ongoing La Niña that developed in August, which typically increases rainfall in the Colombian highlands.

During Ecuador's rainy season, which extends from January to April, both the coastal and Amazon region registered hundreds of extreme events, including 594 landslides, 234 floods, and 125 structural collapses. For the Pichilingue $\left(1.1^{\circ} \mathrm{S}, 79.5^{\circ} \mathrm{W}\right)$ meteorological station, the 24 -hour precipitation total on 9 February was $156.4 \mathrm{~mm}$, a 25 -year return period. On 7 March, the Milagro $\left(2.1^{\circ} \mathrm{S}, 79.6^{\circ} \mathrm{W}\right)$ meteorological station registered $156.3 \mathrm{~mm}$, also a 25 -year return period. In total, more than 72,000 people were affected, with 73 deaths and injuries reported. Over 4500 homes and 3330 ha of crops were damaged or destroyed.

2) CENTRAL SOUTH AMERICA-J. A. Marengo, J. C. Espinoza, L. M. Alves, J. Ronchail, A. P Cunha, A. M. Ramos, J. Molina-Carpio, K. Correa, W. Lavado-Casimiro, J. Baez, and R. Salinas

This region includes Brazil, Peru, Paraguay, and Bolivia.

\section{(I) TEMPERATURE}

The 2020 temperature for central South America was $+0.8^{\circ} \mathrm{C}$ above normal and was the second highest for the region since 1960 (Fig. 7.13). Only 2015 had a higher temperature departure, which was mainly due to the influence of the warm-phase El Niño that was present in the tropical Pacific Ocean at the end of the year. In 2020, a moderate cool-phase La Niña was present in the tropical Pacific Ocean. The annual mean temperature for 2020 was $0.5^{\circ}-1.0^{\circ} \mathrm{C}$ above normal across most of Peru, northern Paraguay, and the eastern Bolivian lowlands. In February and March, temperatures departures from average of $+3^{\circ} \mathrm{C}$ were observed across the northern Peruvian coast.

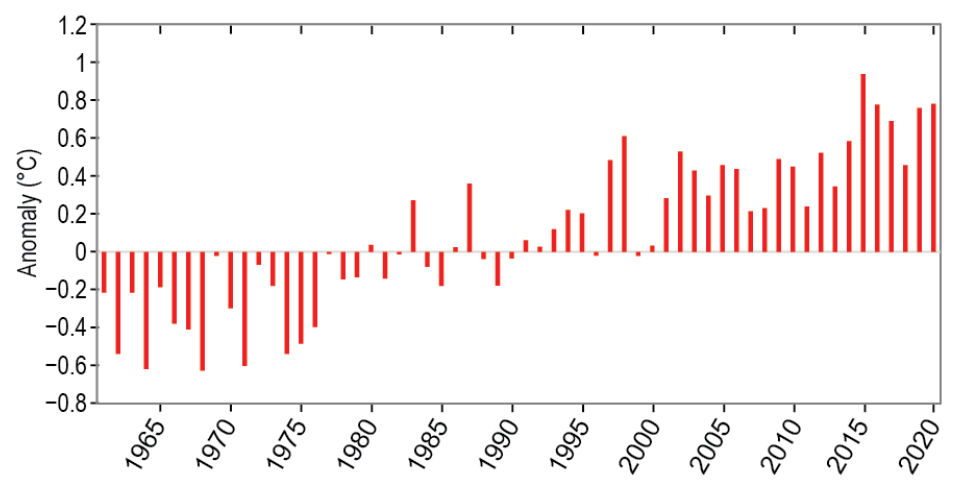

Fig. 7.13. Time series of mean annual regional air temperature anomalies $\left({ }^{\circ} \mathrm{C}\right)$ from 1961 to 2020 for central South America (Brazil, Bolivia, Paraguay, and Peru). Anomalies are relative to 1981-2010 base period. (Source: HadCRUT4.)

\section{(II) PRECIPITATION}

Annual precipitation was below normal across most of central South America, including the central Andes, the Amazon, the Pantanal regions, and southeastern South America. The austral summer was characterized by below-normal rainfall in Amazonia and southern Brazil. Abovenormal rainfall was observed across the semiarid area of northeastern Brazil during March-May, ending a 6-year drought in that region. In Peru, there were several episodes of extreme rainfall in the Andes during the austral summer, while drought was reported along the northern Peruvian coast (see Notable events and impacts).

Dry conditions spanned from May to November across most of the central Andes, with several stations recording less than half of their normal precipitation. This resulted in a delayed onset of the rainy season by at least 10 days, which affected crop production. During September-November, the Bolivian lowlands suffered one of its most severe droughts on record, depleting soil water storage and favoring wildfire development. As indicated by the Integrated Drought Index (IDI; Cunha et al 2019), droughts also spanned the Paraguayan Chaco, the Pantanal, and southern 

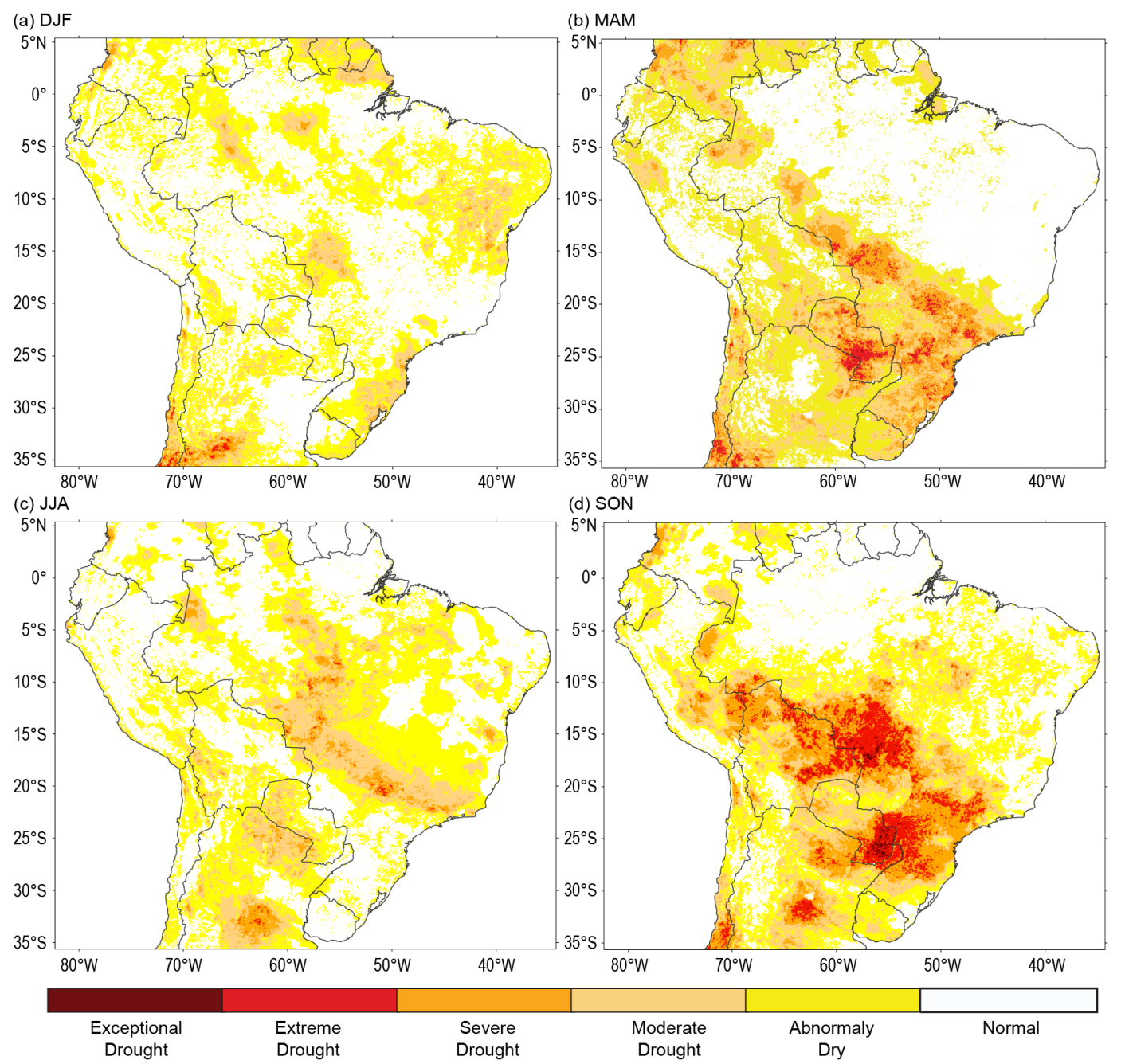

Fig. 7.14. Integrated Drought Index (IDI) maps for central South America during (a) DJF 2019/20, (b) MAM 2020, (c) JJA 2020, and (d) SON 2020. (Source: CEMADEN.).

Brazil during the same period (Figs. 7.14a-d). The IDI combines a meteorological-based drought index and remote sensing-based index to assess drought events (Cunha et al. 2019). The Paraguay River shrank to its lowest levels in half a century, resulting in potable water accessibility issues and limited river traffic (see Notable events and impacts).

\section{(III) NOTABLE EVENTS AND IMPACTS}

Several significant weather and climate extreme events occurred across central South America during the year that are depicted in Fig. 7.15. Some of the events described below are included in this figure.

On 8-9 January and again on 10 February, heavy rainfall affected the city of São Paulo, Brazil, triggering landslides and flash floods that left 24 dead and 5150 homeless. In Belo Horizonte (Minas Gerais), on 16-17 February, flash floods left 61 people dead and more than 3000 homeless.

During January-March heavy rain triggered floods and landslides that affected most of the Peruvian coastal and Andean regions. On 22-23 January, the southern coast of Peru received record-breaking rainfall of $13 \mathrm{~mm} \mathrm{day}^{-1}$ in regions where it normally does not rain. On 21-22 February, exceptional rainfall was reported along the southern coast of Peru; landslides and overflows damaged four districts of the Tacna region, where three people died. The Chili River (Arequipa) flow rate reached $81.7 \mathrm{~m}^{3} \mathrm{~s}^{-1}$, which is $68.7 \mathrm{~m}^{3} \mathrm{~s}^{-1}$ above normal, producing floods that damaged over 470 houses.

In La Paz and other Andean departments of Bolivia, severe weather during January and February affected over 11,600 families and 5300 ha of agricultural crops, and caused 18 fatalities. Later 
in the year, record-breaking precipitation was received on 20 August $(136.8 \mathrm{~mm}$, the highest daily record for August), following several days of heavy rainfall; several zones of Santa Cruz city were flooded. Rainfall during August 2020 was also a record for the month with a total of $312.7 \mathrm{~mm}$, more than $800 \%$ of average $(41 \mathrm{~mm})$.

During 30 June-1 July, an intense extratropical cyclone reached southern Brazil. On 30 June, the mean sea level pressure at the core of the system was $1004 \mathrm{hPa}$, dropping to $972 \mathrm{hPa}$ on $1 \mathrm{July}$ within 24 hours, bringing tornadoes, hail, and wind gusts exceeding $130 \mathrm{~km} \mathrm{~h}^{-1}$. The storm caused 18 fatalities in southern Brazil due to falling trees and structures, affected 229 municipalities, and left 2600 people homeless. About 639,000 people in Rio Grande do Sul and 1.5 million in Santa Catarina were left without electricity.

A severe cold wave affected the southern Peruvian Andes in early July, with temperatures dropping as low as $-22.6^{\circ} \mathrm{C}$ in Mazocruz (Puno) on 3 July, $9.6^{\circ} \mathrm{C}$ below the average minimum temperature for July. Lima, Peru, had two unusual cold episodes with temperatures below $10^{\circ} \mathrm{C}$ on 18 July $\left(9.6^{\circ} \mathrm{C}\right.$, average is $\left.13.9^{\circ} \mathrm{C}\right)$ and 13 August $\left(9.5^{\circ} \mathrm{C}\right.$, average is $\left.13.8^{\circ} \mathrm{C}\right)$. These two episodes brought the lowest minimum temperatures since 1985. During 21-23 August, a cold air outbreak affected southeastern Brazil in Curitiba and São Paulo. The cold wave reached the lower Chaco region of Paraguay and also affected the western Amazonia of Brazil and the city of Iquitos in the northern Peruvian Amazon.

A strong heat wave episode (15 days with maximum temperature above the 90th percentile) affected southeastern and central-western Brazil, Bolivia, and Paraguay during the first half of October. During that time, the city of São Paulo recorded four of its five highest daily maximum temperatures on record (for example, $37.5^{\circ} \mathrm{C}$ on 2 October, highest temperature in 77 years; average is $24.8^{\circ} \mathrm{C}$ ). Several locations across the Bolivian lowlands and in Paraguay also had their highest maximum temperature on record (Fig. 7.15). Of note, Sao José de Chiquitos recorded a maximum temperature of $43.4^{\circ} \mathrm{C}$ on 8 October (average is $33.9^{\circ} \mathrm{C}$ ) and Concepción in Paraguay registered $42.6^{\circ} \mathrm{C}$ on 2 October (average is $33.4^{\circ} \mathrm{C}$ ).

A weak summertime rainy season in the Pantanal started in 2019 and continued in 2020. Between January and August, rainfall was 50\% below normal in the Brazilian Pantanal (up to $300 \mathrm{~mm} \mathrm{month}{ }^{-1}$ below normal) and the Upper Parana basin. The number of fires registered by

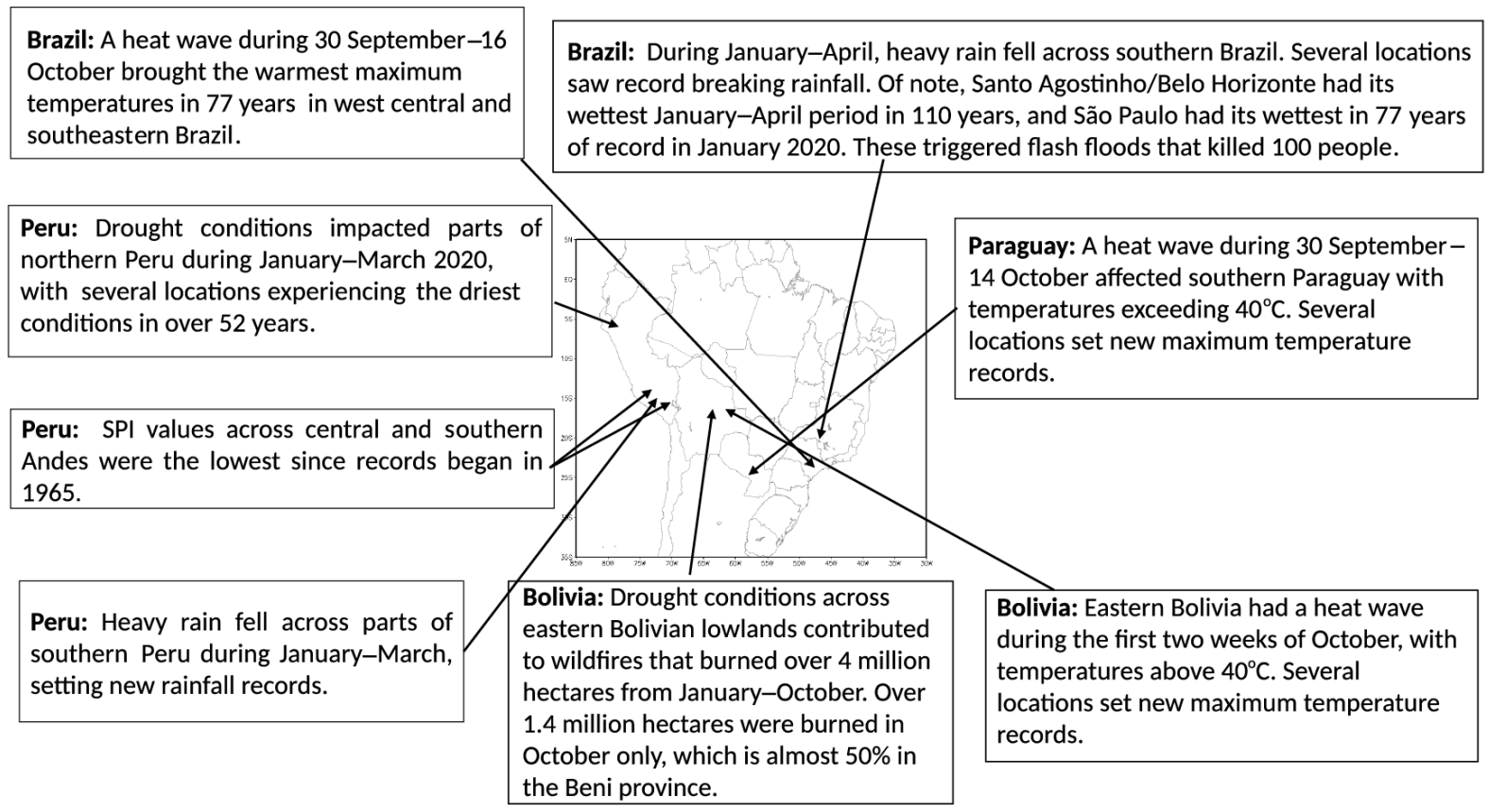

Fig. 7.15. Map depicting date, approximate location, and type of selected notable extreme weather events across central South America. (Sources of data: Peru: SENAMHI; Bolivia: SENAMHI, FAN; Paraguay: DMH; Brazil: INMET, CEMADEN, Climatempo, INPE; International: UN OCHA, Web Relief.) 
National Institute for Space Research (INPE) in the Brazilian Pantanal exceeded last year's value by $241 \%$ (Marengo et al 2021). The levels of the Paraguay River at Ladário were below average since 2018 and continued to drop into 2020. The drought and anomalous warm weather in these regions spread devastation and increased the fire risk in agricultural land and protected areas and affected population and goods transportation along the Paraguay River (Marengo et al 2021).

Most of northern Peru experienced rainfall deficits between 15\%-100\% during its austral summer. By March, the discharge of the Chicama River was $38.81 \mathrm{~m}^{3} \mathrm{~s}^{-1}$, which is about $70 \%$ less than its normal rate. The low levels of the main reservoirs (Gallito Ciego, Tinajones, and Poechos) affected water supply for agriculture in the irrigated region.

\section{3) Southern South America一J. L. Stella, N. Misevicius, and C. Cortés}

This region includes Argentina, Chile, and Uruguay.

\section{(I) TEMPERATURE}

Above-normal temperatures were observed across most of southern South America (SSA) during 2020, with annual mean anomalies between $+0.5^{\circ} \mathrm{C}$ and $+2.0^{\circ} \mathrm{C}$ in large areas. A small region, including Uruguay and adjacent areas of Argentina, recorded near-normal temperatures. The 2020 national mean temperature anomalies for Argentina $\left(+0.63^{\circ} \mathrm{C}\right)$ and Chile $\left(+0.83^{\circ} \mathrm{C}\right)$ were the second and third highest, respectively, since national records began in 1961, while Uruguay had a temperature anomaly $\left(+0.08^{\circ} \mathrm{C}\right)$ that was near normal. The decadal mean temperature for 2011-20 was the highest on record for Argentina, with a significant positive trend since 2001 (Fig. 7.16).

Summer 2019/20 was characterized by normal to above-normal temperatures across the region, with pronounced sub-seasonal variability over the eastern part. Western provinces of Argentina were affected by several heat waves (defined as minimum and maximum temperature surpassing the 90th percentile for three or more consecutive days) during the latter part of January. An 11-day heat wave record was set in both the cities of San Rafael and Malargüe.

Autumn was extremely warm over most parts of SSA. Both Atlantic and Pacific high-pressure systems weakened during this season, favoring a high-pressure blocking pattern over the continent, which discouraged the normal cold front passages such that sunny and warmer-than-average days prevailed during the season. March was extremely hot over the region and several locations broke historical records. The national mean monthly temperature anomaly for Argentina was $+2.0^{\circ} \mathrm{C}$, breaking the previous record set in March $1980\left(+1.8^{\circ} \mathrm{C}\right)$. Uruguay had its second-warmest March since records began in $1961\left(+1.7^{\circ} \mathrm{C}\right)$. A late heat wave during the first half of the month affected parts of central and northern Argentina and Uruguay. The city of Artigas reported a maximum temperature of $40.2^{\circ} \mathrm{C}$ on $13 \mathrm{March}$, tying the national temperature record that was set in the city of Treinta y Tres in March 1970.

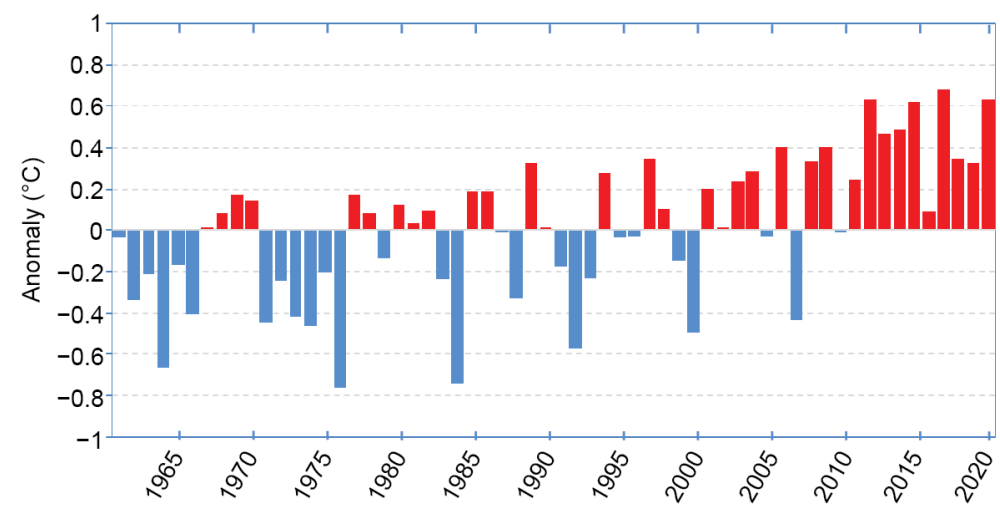

Fig. 7.16. Annual mean temperature anomaly $\left({ }^{\circ} \mathrm{C} ; 1981-2010\right.$ base period) time series from 1961 to 2020 for Argentina. 
Austral winter had near-normal temperatures across most of SSA, with the exception of the extreme north and extreme south regions, where above-normal and below-normal temperatures, respectively, prevailed. Sub-seasonal variability was predominant during the season. The end of June through July was particularly cold over southern Argentina and Chile. Extreme cold waves (defined as when the minimum and maximum temperatures are below the 10th percentile for three or more consecutive days) affected this region. Daily temperatures were as low as $-20^{\circ} \mathrm{C}$ in Perito Moreno, Argentina, on 27 June. Puerto Natales, in Chile, reported its lowest temperature on record $\left(-13.1^{\circ} \mathrm{C}\right)$ on 28 June. The extreme low temperatures caused lakes, seas, and soil to freeze near Puerto Natales and Río Grande.

Spring was characterized by above-normal temperatures over most parts of Argentina and Chile, while Uruguay had near-normal conditions. Maximum temperatures were extremely high in the north in part due to severe drought conditions that prevailed during most of the year. An unusual extreme hot spell affected the region from 25 September to 2 October. Temperatures rose well above $40^{\circ} \mathrm{C}$ for several days and some local all-time maximum temperature records were broken $\left(43.5^{\circ} \mathrm{C}\right.$ in Corrientes; $40.0^{\circ} \mathrm{C}$ in Oberá). For the first time since records began, a temperature above $40^{\circ} \mathrm{C}$ was observed in Iguazú $\left(40.1^{\circ} \mathrm{C}\right)$.

\section{(II) PRECIPITATION}

Much of SSA had below-average annual rainfall during 2020. Rainfall deficits were $20 \%-60 \%$ below average north of $35^{\circ} \mathrm{S}$ and south of $40^{\circ} \mathrm{S}$. A small area in the central part of SSA recorded near-normal precipitation. The year was characterized by a severe drought that impacted most of La Plata Basin (see Notable events and impacts). Argentina had its driest year since 1995 and fifth driest since national records began in 1961. The central-southern region of Chile reported its 11th consecutive year with a rainfall deficit. This period is known as a "Mega-drought." For Uruguay, 2020 was the third-driest year since 1981.

Below-normal rainfall dominated all Uruguay and Chile and much of Argentina during austral summer 2019/20. However, intense precipitation affected parts of Argentina during 4-15 February, especially in the provinces of Tucuman, Salta, Jujuy, Chaco, Santiago del Estero, and Córdoba, with daily rainfall totals up to $175 \mathrm{~mm}$. Thunderstorms with intense precipitation affected the Atacama Region of northern Chile during the last week of January. The rainfall over the mountains triggered landslides and river floods in populated locations, causing severe damage.

Autumn was extremely dry across the region. Precipitation anomalies were $20 \%-60 \%$ below average over northern Argentina, central Chile, and Uruguay. At the end of the season, the first significant snowfall took place in the northwest Chubut province in Argentina. The city of Esquel reported a $15 \mathrm{~cm}$ snowfall total during 27-29 May.

Drought conditions worsened in northeastern Argentina and northern Uruguay, triggering several bushfires that severely affected Cordoba province and the Delta del Paraná region in Argentina. Meanwhile, southern Argentina and southern Chile were affected by heavy snowfall and rainfall several times during June and July (see Notable events and impacts). Southern Uruguay had above-normal precipitation, particularly due to heavy rainfall in June.

During spring, dry conditions persisted in SSA. In combination with high temperatures, the occurrence of severe bush fires extended to many other regions across Argentina. Precipitation anomalies were 40\%-80\% below normal in northeastern Argentina, its driest spring on record.

\section{(III) NOTABLE EVENTS AND IMPACTS}

Northern and central Argentina and Uruguay were severely affected by one of the worst droughts ever recorded in the region. The drought, which began in 2019, continued during 2020 after a weak summertime rainy season. Rainfall deficits of up to $300 \mathrm{~mm} \mathrm{month} \mathrm{m}^{-1}$ below normal were detected over the Upper Parana River basin. By the end of spring, the drought worsened north of $35^{\circ} \mathrm{S}$. Dry and warm conditions favored the development of fires, affecting human activities 


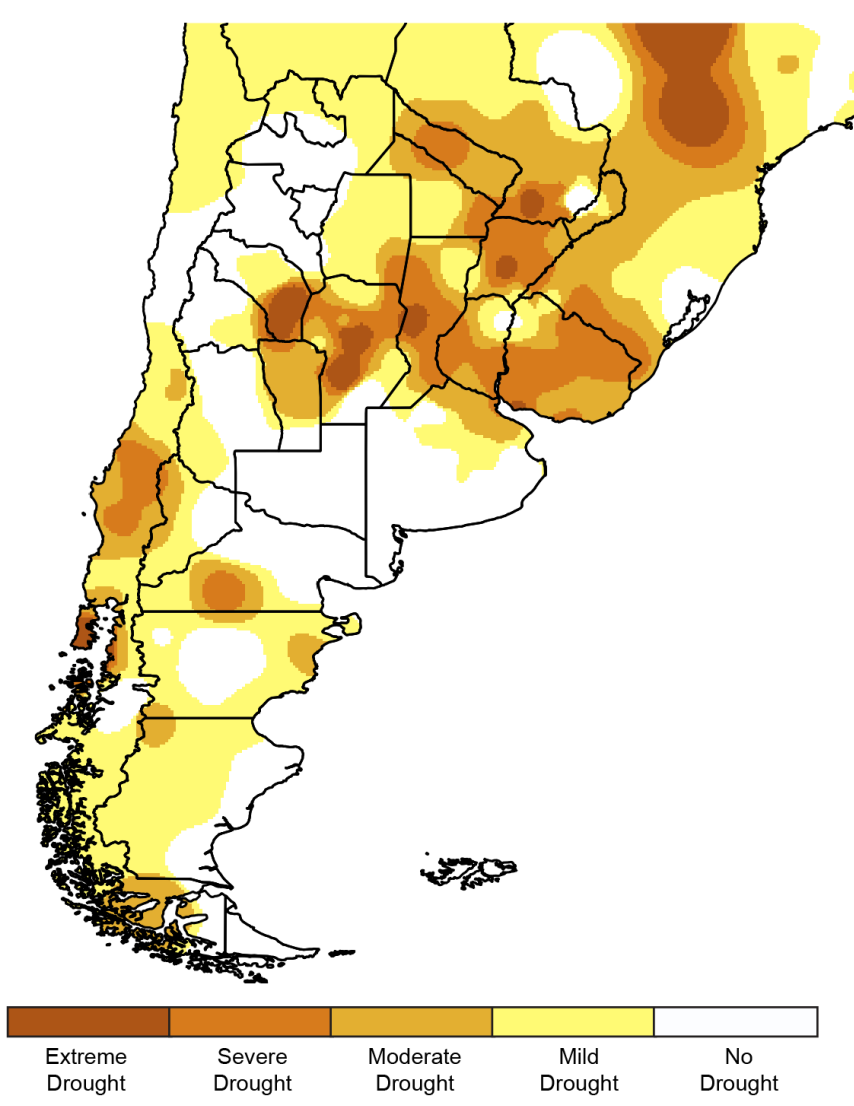

Fig. 7.17. SPI map for the 12-month period Jan-Dec 2020 for southern South America. and biodiversity. For the year, the Standardized Precipitation Index indicated a classification of severe drought for several locations in Argentina, Uruguay, and also in Chile (Fig. 7.17).

A snowy winter was observed in southern Argentina. Major snowfalls occurred between the end of June and during July, reaching the plateau as well as the coast. Some locations were affected by blocked roads and power outages, among other impacts. According to estimated satellite measurements, the snow cover extent during May-October for central and southern Patagonia was the highest since 2000 (Fig. 7.18).

\section{e. Africa-A. Mekonnen, Ed.}

Analyses in this section are based on observational records from meteorological and hydrological services across Africa. Additionally, rainfall data from the Global Precipitation Climatology Project (GPCP) and temperature reanalysis data from the National Centers for Environmental Prediction/National Center for Atmospheric Research (NCEP/NCAR) were also used. Notable events are based on reports from government agencies, research/Early Warning organizations, and United

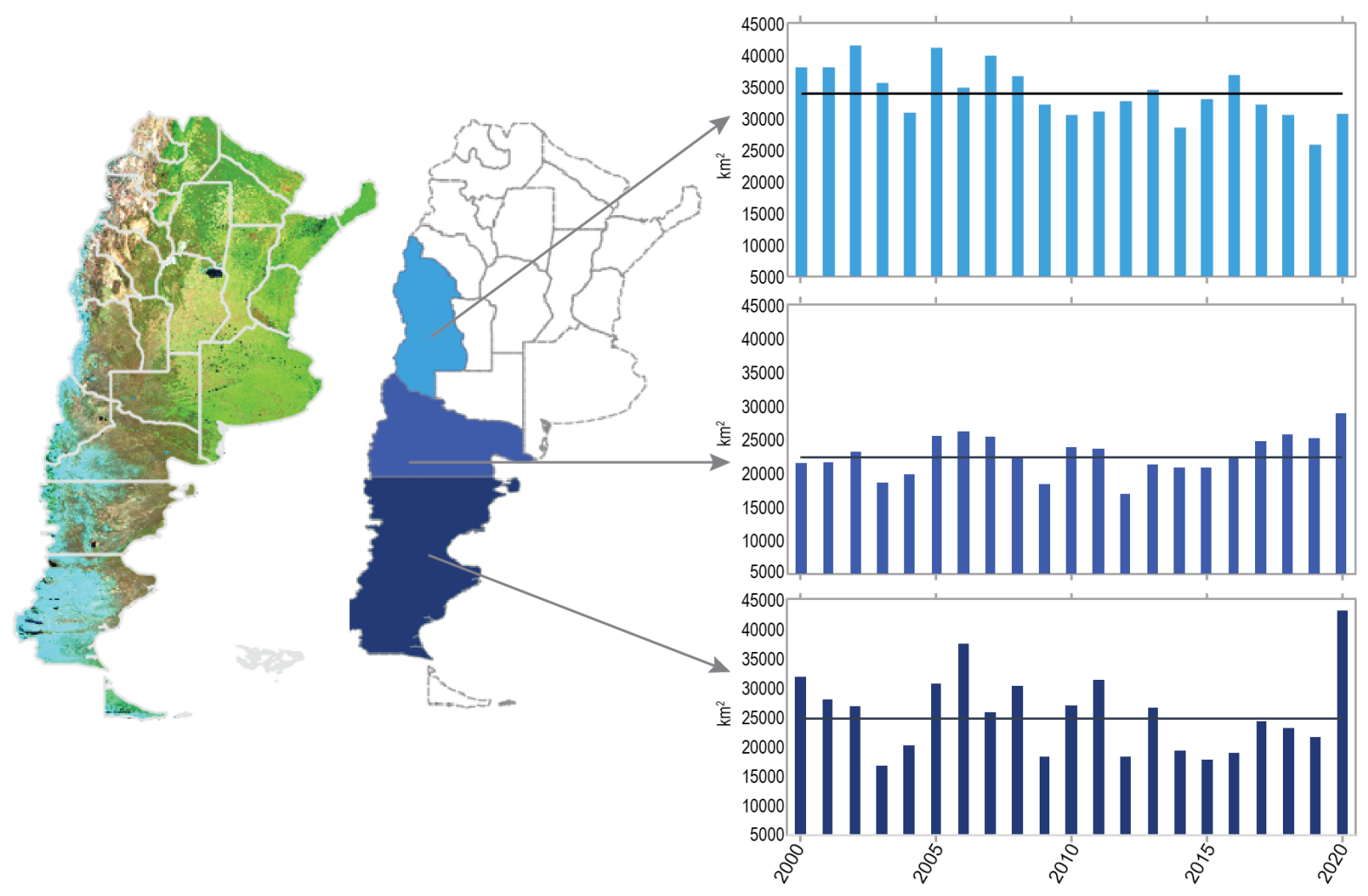

Fig. 7.18. (left) Satellite measurements (MODIS) of snow cover extent ( $\mathrm{km}^{2}$; light blue in left-side map) during May-Oct 2020 over central and southern Patagonia. (right) May-Oct snow cover extent $\left(\mathrm{km}^{2}\right)$ shown in time series for the period 2001-20 for three regions, as depicted on the right-side map. 
Nations (UN)-based agencies. The climatological base period used is 1981-2010. Here, temperature and precipitation base periods are referred to interchangeably as average or normal.

In 2020, large parts of northern and equatorial Africa observed above-normal temperatures, while an area centered around the borders between northern Nigeria, southern Niger, and southwestern Chad experienced temperatures up to $1.5^{\circ} \mathrm{C}$ below normal. Most of South Africa, Namibia, and southern Angola also had below-normal annual temperatures (Fig. 7.19a).

Annual rainfall over the Sahel and eastern Africa, including border areas between Congo and the Democratic Republic of Congo, was above normal. The southern coast of West Africa south of $10^{\circ} \mathrm{N}$ and most of southern Africa (south of $10^{\circ} \mathrm{S}$ ) received below-normal annual rainfall (Fig. 7.19b).

Extreme weather events and high climate variability were reported across the continent. These include heavy rainfall, extreme flooding, locust infestations, and land-falling tropical cyclones.
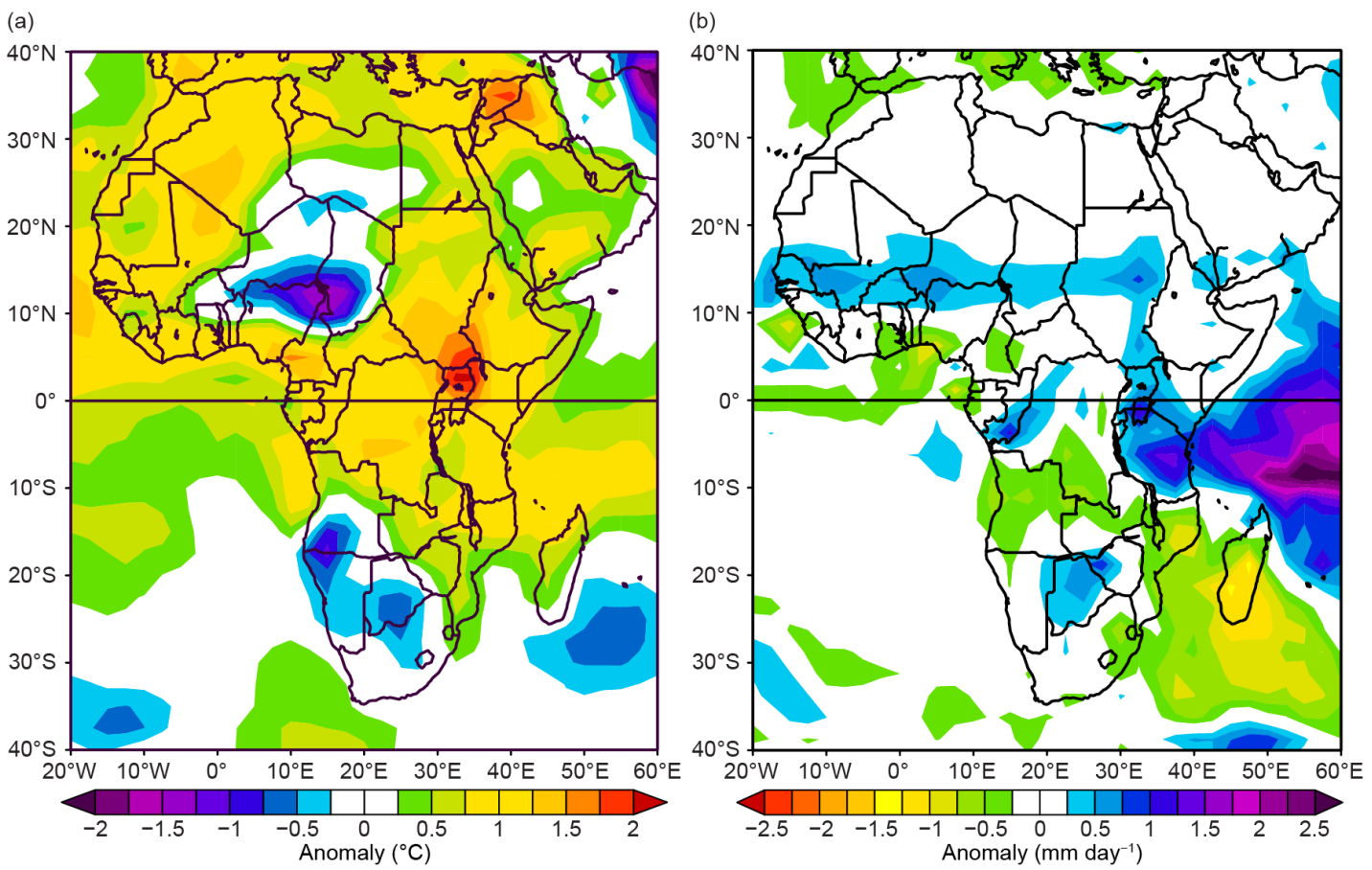

Fig. 7.19. Annual (a) temperature anomalies $\left({ }^{\circ} \mathrm{C}\right)$ and rainfall anomalies $\left(\mathrm{mm}\right.$ day $\left.{ }^{-1}\right)$ 1981-2010 base period. (Sources: NCEP/NCAR and GPCP.)

1) North Africa—K. Kabidi, A. Sayouri, M. ElKharrim, and A. E. Mostafa

This region, which includes Morocco, Algeria, Tunisia, Libya, Mauritania, and Egypt, is characterized by arid and semi-arid climate. Precipitation over the region is highly variable both in space and time. Rainfall over western North Africa (comprising Morocco and northern and western Algeria) is generally of a short duration but at times intense. Mauritania in the south is characterized by arid to desert climate.

In 2020, above-normal annual mean temperatures dominated most of Mauritania, Morocco, Algeria, and Egypt, while southern Libya observed below-normal temperatures. Moroccan records show that annual temperatures across the country were about $1.2^{\circ} \mathrm{C}$ above normal, and precipitation was $32 \%$ below normal.

\section{(I) TEMPERATURE}

Winter (December-February) 2019/20 temperatures were above normal over most of Morocco $\left(+0.9^{\circ} \mathrm{C}\right)$, northern Algeria, and Tunisia. Below-normal temperatures were observed over southern Morocco, Mauritania, southern Algeria, Libya, and Egypt (Fig. 7.20a). Temperatures of $1.5^{\circ}$ to $2^{\circ} \mathrm{C}$ below normal dominated southern Libya and southwestern Egypt. Egyptian meteorological 

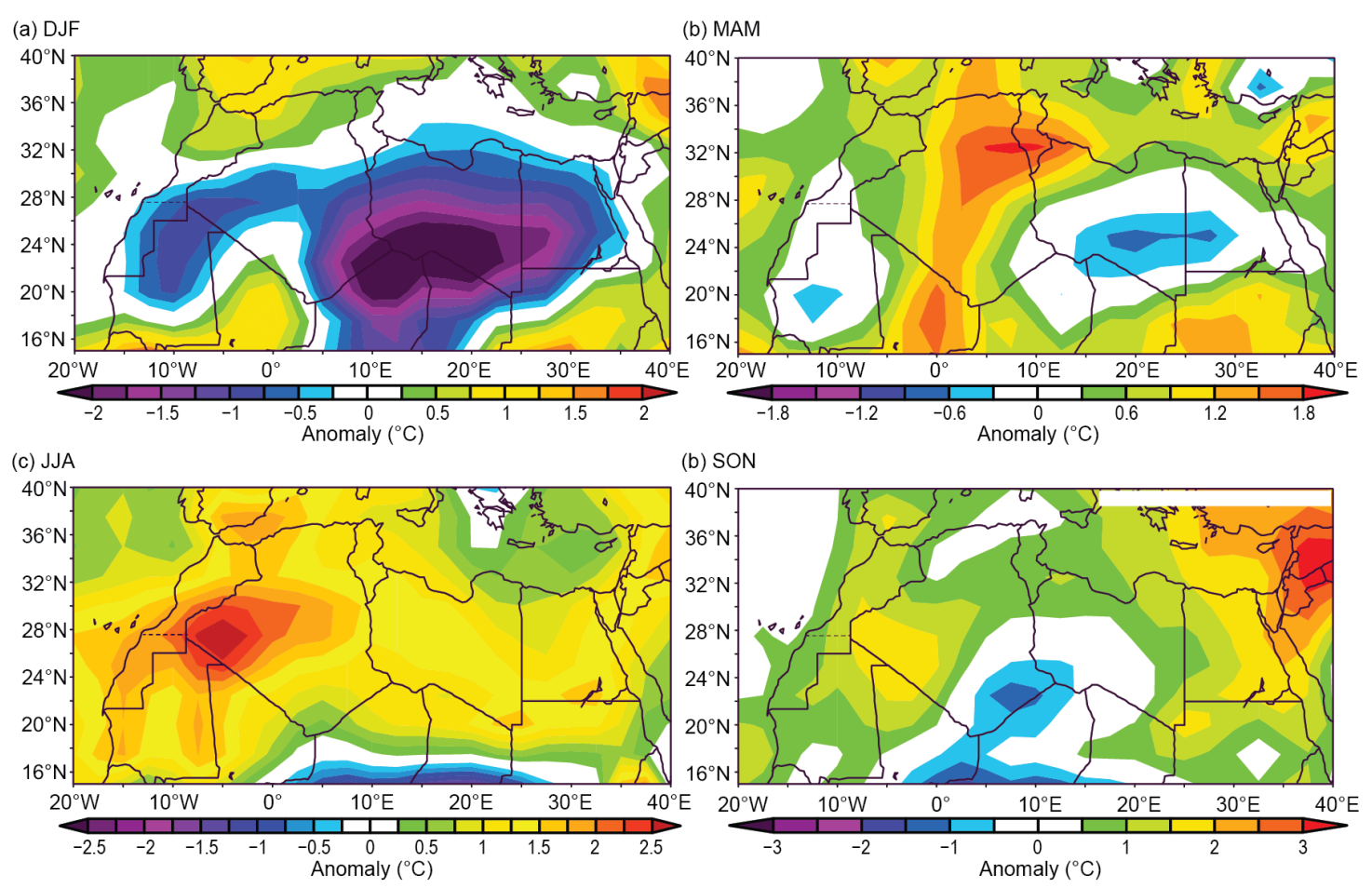

Fig. 7.20. North Africa seasonally averaged mean temperature anomalies $\left({ }^{\circ} \mathrm{C} ; 1981-2010\right.$ base period) for (a) DJF 2019/20, (b) MAM 2020, (c) JJA 2020, and (d) SON 2020. (Source: NOAA/NCEP.)

records show above-normal temperatures over the north of the country in December, but January temperatures were as much as $2^{\circ} \mathrm{C}$ below normal, particularly notable over the southern half. Still, warmth prevailed for the season: a new February temperature record of $3.8^{\circ} \mathrm{C}$ above normal was recorded at Port Said in northeastern Egypt.

In spring (March-May), temperature anomalies varied across the region (Fig. 7.20b). Abovenormal temperatures were observed from northern Mali northward through Algeria, the northern half of Morocco, and Tunisia, while below-normal temperatures were observed to both the west and east of this region (Fig. 7.20b). Stations in the northern mountainous area of Morocco reported monthly maximum temperatures up to $6^{\circ} \mathrm{C}$ above normal in May (not shown). In Egypt, May was also exceptionally warm, with some stations reporting monthly average temperatures up to $4^{\circ} \mathrm{C}$ above normal.

Summer (June-August) was warmer than normal throughout the region (Fig. 7.20c). Southeastern Morocco, southwestern Algeria, and northern Mauritania exhibited mean temperature anomalies greater than $+2^{\circ} \mathrm{C}$. Temperatures exceeding $40^{\circ} \mathrm{C}$ were reported from Morocco during July and August. High daytime temperatures were also reported from Egypt. For example, $46^{\circ} \mathrm{C}$ was recorded at Kharga in central Egypt on 31 July. A continuation of above-normal temperatures across Algeria, Morocco, Mauritania, and the eastern half of Egypt (Fig. 7.20d) was observed in autumn (September-November); however, minimum temperatures over Morocco were below normal. Southwestern Libya and southeastern Algeria had mainly below-normal temperatures in autumn.

\section{(II) PRECIPITATION}

Generally, precipitation in 2020 was below normal with marked variability across the region and over time. Strong deficits, as much as $90 \%$ below normal, were reported from the Saharan region of Morocco. In winter, precipitation was below normal over most of the region (Fig. 7.21a). Morocco reported an overall precipitation deficit up to 56\% below normal. Despite an overall winter rainfall deficit, some stations in Egypt reported heavy downpours in January. 



Fig. 7.21. North Africa seasonally averaged rainfall anomalies (mm day ${ }^{-1} ; 1981-2010$ base period) for (a) DJF 2019/20, (b) MAM 2020, (c) JJA 2020, and (d) SON 2020. (Source: NOAA/NCEP.)

Most of northern Morocco, northern Algeria, Tunisia, and Egypt received above-normal rainfall during spring, while the remainder of the region was near normal (Fig. 7.21b). Rainfall in April varied widely across Morocco, with stations reporting between $23 \%$ and $265 \%$ of normal. In May, Morocco reported 75\% above-normal precipitation.

Summer is typically a dry season for North Africa, and the seasonal rainfall was near normal across the region (Fig. 7.21c). In contrast, above-normal rainfall was observed over most of the region during autumn (Fig. 7.21d). Rainfall between 20\% and 100\% of normal was reported in November from southern and central Morocco. Cairo, Egypt, reported $71 \mathrm{~mm}$ of rainfall on 14 November, the highest 24-hour total on record.

\section{(III) NOTABLE EVENTS AND IMPACTS}

Reports from Morocco indicated severe flood occurrences during March and November 2020 that caused property damage and cost human lives. Morocco also reported significant damages caused by forest fires that were associated with high summer temperatures, some of which exceeded $40^{\circ} \mathrm{C}$ in July and August. Similarly high temperatures were observed in Algeria. In Egypt, temperatures reached as high as $46^{\circ} \mathrm{C}$ at Luxor in the southeast.

2) West Africa-S. Hagos, W. M. Thiaw, Z. Feng, J. A. ljampy, F. Sima O. Ndiaye, P-H. Kamsu-Tamo, A. Diawara, and S. Diouf

West Africa extends from the Guinea coast to about $20^{\circ} \mathrm{N}$ and from the eastern Atlantic coast to Niger. Climatologically, it consists of two distinct but inherently linked sub-regions: (1) The Sahel to the north from about $12^{\circ} \mathrm{N}$ to $17^{\circ} \mathrm{N}$, spanning countries from Senegal and The Gambia in the west to Niger in the east and (2) the Gulf of Guinea to the south from about $4^{\circ} \mathrm{N}$ to $10^{\circ} \mathrm{N}$ encompassing the Guineas to the west along the east Atlantic coast and Nigeria and Cameroon to the east. The Sahel is semi-arid, while the Coast of Guinea region has a wet tropical climate. The West African monsoon season is associated with the latitudinal movement of a section of the active convective zone associated with the Saharan heat low in the north and its northerly reach limited by Harmattan winds from the northeast. The wet period runs from June through September. 
Interannual variations of this seasonal rainfall are controlled by sea surface temperature (SST) fluctuations across the Gulf of Guinea the Mediterranean Sea, and the equatorial east Pacific. At longer timescales, the Atlantic multidecadal oscillation (Martin and Thorncroft 2014) and tropical Indian Ocean SSTs (Giannini et al. 2003) are known to modulate Sahel precipitation. Through most of summer 2020, El Niño-Southern Oscillation (ENSO) conditions were neutral and trending toward La Niña, while the Gulf of Guinea was slightly cooler than normal, both of which typically favor wet conditions over the Sahel region (Janicot et al. 2001; Zhang et al. 2021).

\section{(I) TEMPERATURE}

The highest mean annual temperatures, between $27^{\circ} \mathrm{C}$ and $30^{\circ} \mathrm{C}$, were observed over the central and western Sahel, encompassing Senegal, southern Mauritania, Mali, and Burkina Faso (Fig. 7.22a). The area along the border of northeastern Senegal and Mauritania recorded mean annual temperatures exceeding $32^{\circ} \mathrm{C}$. Mean annual temperatures were lower over the Gulf of Guinea region, between $24^{\circ} \mathrm{C}$ and $26^{\circ} \mathrm{C}$, over the central areas from Guinea to Benin and much of Nigeria. Mean annual temperatures were about $27^{\circ} \mathrm{C}$ along the Gulf of Guinea coast and over the northern areas of Cote d'Ivoire, Ghana, Togo, and Benin, extending into northwestern and northeastern Nigeria. Maximum temperatures between $40^{\circ} \mathrm{C}$ and $46^{\circ} \mathrm{C}$ were reported from stations in Nigeria between March and June. About 80 days of maximum temperatures exceeding $40^{\circ} \mathrm{C}$ were reported from Nuguru, Nigeria, surpassing its previous record of 77 days in 2019.

Mean annual temperatures were above normal over much of the western and central Sahel and along the Guinea coast, with departures of about $+0.5^{\circ}$ to $+1^{\circ} \mathrm{C}$ (Fig. 7.22b). Western Mali, southeastern Senegal, western Guinea, and coastal Gulf of Guinea registered mean annual temperatures above their 90th percentiles (not shown). Mean annual temperatures were below normal over northern Benin and Nigeria and in southern Niger by as much as $-1.5^{\circ} \mathrm{C}$ (Fig. $7.22 \mathrm{~b}$ ), with the lowest temperatures in the past 30 years recorded in northeastern Nigeria. Annual maximum temperatures were overall below normal across the Sahel but exceeded $38^{\circ} \mathrm{C}$ in southern Mauritania, central Mali, and portions of northwestern and northeastern Niger (not shown). In the Gulf of Guinea, annual maximum temperatures ranged from $24^{\circ}$ to $30^{\circ} \mathrm{C}\left(+1^{\circ}\right.$ to $+3^{\circ} \mathrm{C}$ above normal). Annual minimum temperatures were above normal in much of West Africa, with the highest departures from the mean about $+2^{\circ}$ to $+3^{\circ} \mathrm{C}$ over eastern Senegal and western Mali (not shown).

In 2020, April, May, and June were the warmest months in the Sahel, with readings exceeding $37^{\circ} \mathrm{C}$ in northern Mali and southern Mauritania, which was $+1^{\circ}$ to $+2^{\circ} \mathrm{C}$ above normal for Mali and $+3^{\circ} \mathrm{C}$ for southern Mauritania. Mean maximum temperatures exceeded $42^{\circ} \mathrm{C}$ in northern
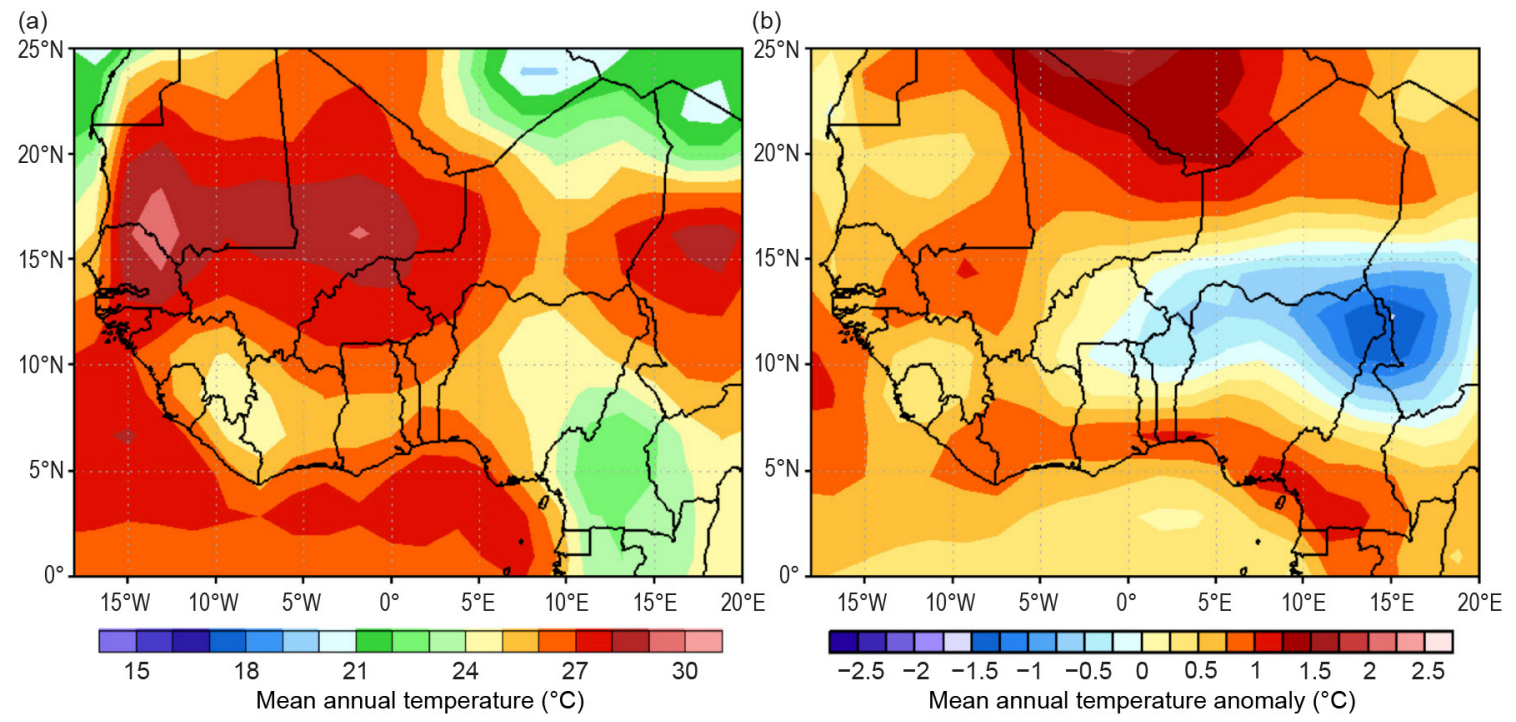

Fig. 7.22. Mean annual (a) temperature and (b) temperature anomalies $\left({ }^{\circ} \mathrm{C} ; 1981-2010\right.$ base period) for West Africa in 2020. (Source: NOAA/NCEP.) 
Sahel during this time, while mean minimum temperatures were $22^{\circ}$ to $26^{\circ} \mathrm{C}$. Temperatures were also significantly above normal across West Africa during December 2020, with departures from the mean averaging $+2^{\circ}$ to $+4^{\circ} \mathrm{C}$ across southeastern Senegal and the western areas of Mali and Burkina Faso. This was due to both elevated maximum and minimum temperatures during the month. Mean monthly temperatures were below normal over the central Sahel, including Burkina Faso, southern Niger, and northern Nigeria during July-September, with temperatures $24^{\circ}$ to $26^{\circ} \mathrm{C}$, about $-1^{\circ}$ to $-2^{\circ} \mathrm{C}$ below the mean. The border between Niger and Nigeria observed its lowest mean July temperatures over the past 30 years.

\section{(II) PRECIPITATION}

Annual rainfall ranged between $1000 \mathrm{~mm}$ and $2000 \mathrm{~mm}$ over the Gulf of Guinea region with the areas of maximum rainfall along the western Guinea coast and over southeastern Nigeria (Fig. 7.23a). Rainfall decreased northward, ranging from 300 to $1000 \mathrm{~mm}$ in the southern and central Sahel. The climatologically dry areas of the Sahel registered rainfall between $50 \mathrm{~mm}$ and $300 \mathrm{~mm}$ (Fig. 7.23a). Consistent with the trend of the last 2 decades and the prominence of the Atlantic Multidecadal Oscillation featuring a warm tropical North Atlantic, annual rainfall was once again above normal across the Sahel (Fig. 7.23b; e.g., Mohino et al. 2011), with surpluses of 100-150 mm from Senegal eastward to Niger and exceeding $150 \mathrm{~mm}$ over the western areas of Mali and Niger (Fig. 7.23b). These large rainfall departures placed much of the Sahel above its 90th percentile, with west central Senegal and southern Niger recording rainfall above the 95th percentile. Departures of +50 to $+100 \mathrm{~mm}$ above normal were observed across the northern Sahel.


Fig. 7.23. Cumulative annual (a) precipitation totals ( $\mathrm{mm}$ ), (b) annual precipitation anomalies (mm), and (c) Jun-Sep precipitation anomalies (mm day ${ }^{-1}$ ) for West Africa in 2020. (Source: NOAA/NCEP and GPCP.) 
Over the Gulf of Guinea region, annual rainfall was much below normal along the eastern Guinea coast, with deficits as much as $150 \mathrm{~mm}$ below the mean along coastal Nigeria (Fig. 7.23b). Rainfall deficits were 50-150 mm farther inland in the southern areas of Ghana, Togo, Benin, and Nigeria. Mean annual rainfall was slightly below normal over southern Guinea and Sierra Leone and was slightly above normal over Liberia and the northern Gulf of Guinea region.

In the Sahel, rainfall during June-September accounts for much of its annual cumulative rainfall. Totals ranged from 100 to $500 \mathrm{~mm}$ in the northern Sahel (just north of $15^{\circ} \mathrm{N}$ ) to $500-1000 \mathrm{~mm}$ in the central areas $\left(12^{\circ}-15^{\circ} \mathrm{N}\right)$ to over $1200 \mathrm{~mm}$ in the areas of maximum precipitation, including the western Guinean coast. These amounts corresponded to above-normal rainfall across the Sahel, with moisture surpluses exceeding $200 \mathrm{~mm}$ across the southern Sahel from Senegal eastward to Niger. The western areas of Niger and Senegal registered rainfall above their 95th percentiles during July-September. Precipitation was significantly below normal over the Sahel in June when much of the precipitation was limited to coastal regions. The situation improved and wetter conditions were observed through the rest of the season for much of West Africa with somewhat drier-than-normal conditions along the Guinean coast (Fig. 7.23c). In Nigeria, 1-day rainfall totals of at least $100 \mathrm{~mm}$ were observed in different parts of the country. The city of Yelwa recorded the highest daily rainfall value of $176.2 \mathrm{~mm}$ in August followed by Ilorin $(160.0 \mathrm{~mm})$, Lafia $(152.0 \mathrm{~mm})$, Jalingo $(148.4 \mathrm{~mm})$, Bauchi $(133.2 \mathrm{~mm})$, and Ibadan $(132.0 \mathrm{~mm})$. The month of September contributed significantly to rainfall surpluses in the western Sahel, with over $300 \mathrm{~mm}$ (100 mm above the mean) over Senegal, following a drier-than-normal August.

In the Gulf of Guinea region, rainfall was significantly above normal along the western Guinea coast during March-May and October-December, with surpluses of about $100 \mathrm{~mm}$ and $200 \mathrm{~mm}$, respectively. In contrast, July-September departures were about $200 \mathrm{~mm}$ below the mean in the southern areas and reached $400 \mathrm{~mm}$ below the mean over Sierra Leone and Liberia.

\section{(III) NOTABLE EVENTS AND IMPACTS}

Extremely heavy rains in West Africa caused many of the countries to face their most devastating floods in recent history. Heavy downpours with accumulations near $100 \mathrm{~mm}$ in June soaked southern Niger, resulting in floods across the sub-region. The towns of Maradi and Tahoua were the hardest hit, with 13,667 and 4173 people affected, respectively, according to the Ministry of Humanitarian Action and Disaster Management. As of 21 July, there were 14 fatalities and more than 35,000 people affected and over 3400 houses destroyed, with loss of livestock and crops. Sustained torrential rains in August and September (the station at Gaya in southwestern Niger recorded $130 \mathrm{~mm}$ from 23-29 August) caused the Niger River to overflow, shutting down the capital, Niamey. An additional $170 \mathrm{~mm}$ between 31 August and 17 September worsened the flood situation as the Niger River rose to approximately $8 \mathrm{~m}$, well above the 6.2-m alert level. According to the government of Niger, as of the end of September, the floods affected about 400,000 people, caused 65 deaths, and severely damaged or destroyed 32,000 houses and 6000 ha of farmland. On 24 August, floods killed three people and displaced 1500 residents in N'Djamena, Chad, according to the International Organization for Migration.

Exceptionally heavy rains across northern and southern Nigeria in late September and early October resulted in widespread floods, compounding the risks to human health and food security. The Benue and Niger Rivers overflowed and caused severe floods in many states, including Kebbi, Niger, Kwara, Kogi, Edo, Anambra, Delta, Kano, Jigawa, Rivers, Bayelsa, and Adamawa. According to the Red Cross, these floods were a result of heavy rainfall in river catchments, coupled with the release of dams in the neighboring countries of Niger, Cameroon, and Benin, which all experienced flooding. In Nigeria, at least 40 people lost their lives. Jigawa State had its worst flood in 32 years, according to the Jigawa State Emergency Management Agency and the International Federation of the Red Cross and Red Crescent Societies (http://floodlist.com/africa /nigeria-floods-october-2020). 
On 8 June, a windstorm and heavy rainfall affected parts of Borno State in northeastern Nigeria, causing damage to shelters in several Internally Displaced People's (IDP) camps, according to the International Organization for Migration. The severe weather also affected around 1200 people and damaged a total of 240 shelters in IDP camps in Jere, Damboa, Konduga, and Maiduguri. The heaviest rainfall occurred in Damboa, Konduga, and Maiduguri, resulting in damage to about 60 shelters (Floodlist, 11 June 2020). Yobe state was also affected by the windstorm.

In early June, torrential rain in Accra, Ghana, led to major flooding and two fatalities, according to the National Disaster Management Organization of Ghana. On 18 June, heavy rains in Abidjan and environs, Ivory Coast, caused flash flooding and landslides that killed 13 people, according to National Office Civil Protection of Ivory Coast.

In Burkina Faso, the northeastern town of Dori registered $298 \mathrm{~mm}$ between 30 July and 11 August, resulting in eight fatalities, according to the government of Burkina Faso. The floods were so widespread between July and September that the government declared a state of emergency and released \$9 million (U.S. dollars) to help flood victims and repair damaged public infrastructure.

In Mali, persistent heavy rains in June and July caused massive flooding in the south. The towns of Mopti and Sikasso were among the hardest hit, with Sikasso receiving cumulative rainfall of 259 and $230 \mathrm{~mm}$ in June and July, respectively. Mopti registered $390 \mathrm{~mm}$ in July, including $145 \mathrm{~mm}$ during 3-5 July and $78 \mathrm{~mm}$ during 30-31 July. According to the UN Office for the Coordination of Humanitarian Affairs, the floods affected more than 13,000 people.

In Senegal, the northern town of Linguere-a climatologically dry area-registered $237 \mathrm{~mm}$ during 1-9 September. The rains were widespread across the country, forcing the government to declare a state of emergency on 5 September. The Senegalese Red Cross Society indicated that the unprecedented rains decimated homes and flooded streets, especially in the capital city of Dakar, with more than 3000 people affected.

In The Gambia, as in the rest of the Sahel region, monsoon rains started late but persisted well past the climatological end of the season. The Gambia experienced its heaviest downpour in October. According to The Gambia Red Cross Society and the National Disaster Management Agency, severe flooding occurred in some parts of the country following heavy downpours on 13 October, especially notable within the Kanifing Municipality and West Coast Region. The floods caused major property damage and destruction, displacement, and health hazards associated with flooding. Some farmlands were washed away by the rains, particularly in the North Bank Region. The rainy season was also marked by significant high winds that caused major damage to homes.

\section{3) Central Africa-W. M. Thiaw and P-H. Kamsu-Tamo}

Central Africa features a unique climate system marked by a strong spatial variability as it spans a wide area of Africa across both the Northern and Southern Hemisphere (NH; SH). The region analyzed in this section extends from the southern tip of the Democratic Republic of Congo (DRC) northward into central Chad. Longitudinally, the region extends from about $5^{\circ} \mathrm{E}$ to about $35^{\circ} \mathrm{E}$. This analysis includes Cameroon, Chad, Central Africa Republic (CAR), DRC, Congo, Gabon, Equatorial Guinea, and São Tomé and Príncipe.

\section{(I) TEMPERATURE}

The mean annual temperature was between $21^{\circ} \mathrm{C}$ and $25^{\circ} \mathrm{C}$ across much of the region, except for southern Chad, where temperatures approached $27^{\circ} \mathrm{C}$ and maximum temperatures were up to $35^{\circ} \mathrm{C}$. However, the relatively high temperatures were $2^{\circ}$ to $3^{\circ} \mathrm{C}$ below normal in some localities in southern Chad. Mean temperatures along coastal Gabon and Congo and over northeastern DRC averaged about $+0.5^{\circ}$ to $+1^{\circ} \mathrm{C}$ above the mean, placing the temperatures in the 90th percentile. Temperatures in local areas in central DRC ranked as high as the 99th percentile (Fig. 7.24a). The months of March-May were the warmest in the northern sector of the region. Mean temperatures 
(a)

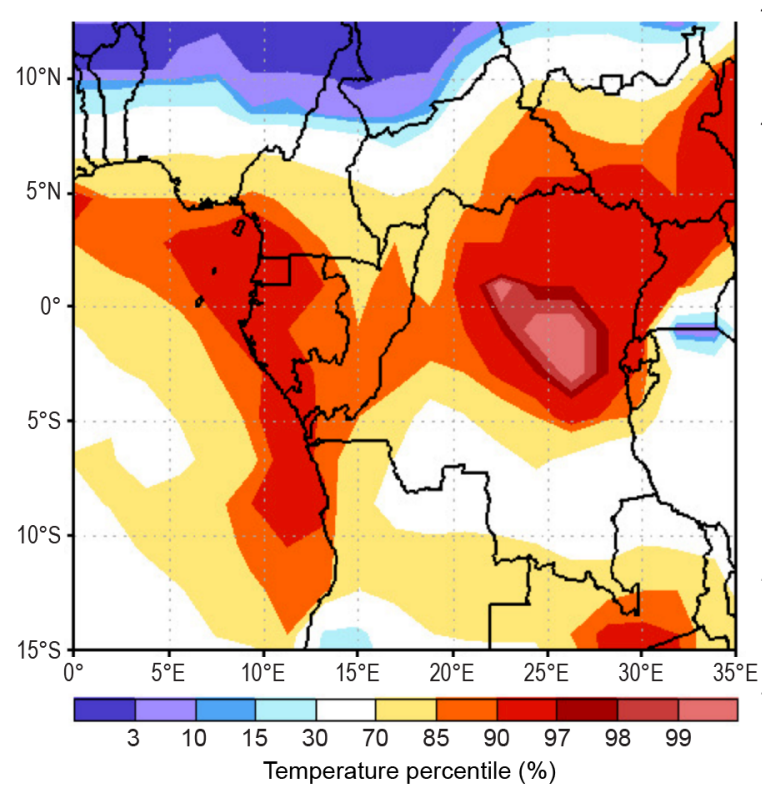

(b)

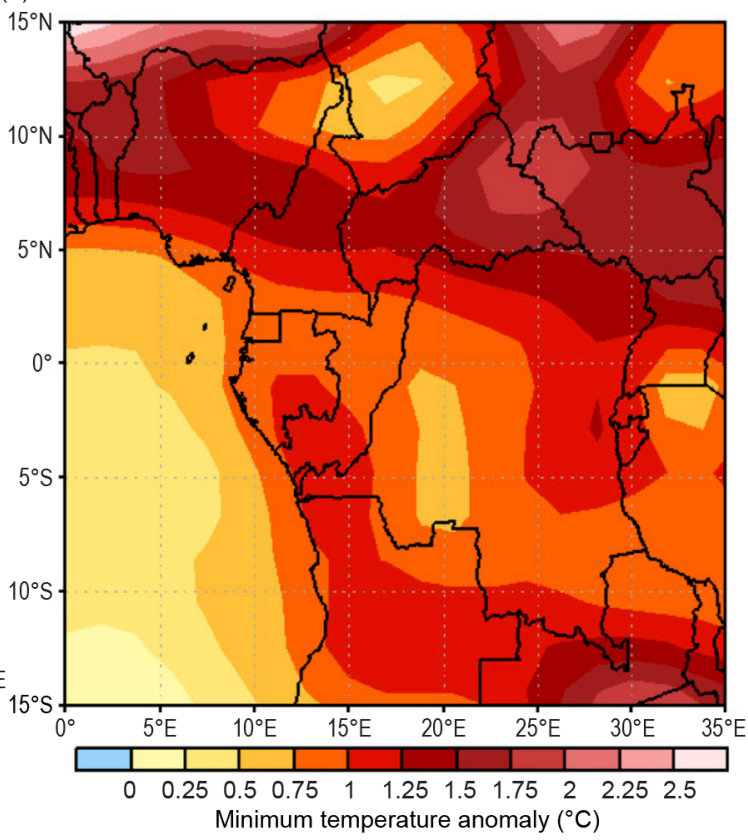

Fig. 7.24. Annual (a) temperature percentiles (\%) and (b) minimum temperature anomalies $\left({ }^{\circ} \mathrm{C}\right)$ for Central Africa in 2020. 1981-2010 base period. (Source: NOAA/NCEP.)

were $28^{\circ}$ to $30^{\circ} \mathrm{C}$ across CAR and northern Cameroon. While the temperature exceeded $35^{\circ} \mathrm{C}$ in some localities in southern Chad in April, this was still about $-1^{\circ} \mathrm{C}$ below the mean. Temperature departures were also $-1^{\circ}$ to $-2^{\circ} \mathrm{C}$ below the mean in northern Cameroon. Though mean temperatures were relatively low in northern Cameroon and CAR in December, around $20^{\circ}$ to $25^{\circ} \mathrm{C}$, this area had the highest positive anomalies of about $+2^{\circ}$ to $+3^{\circ} \mathrm{C}$ above the December mean, placing this month in the 99th percentile. Maximum temperatures for this region in December exceeded $30^{\circ} \mathrm{C}$, more than $+2^{\circ} \mathrm{C}$ above the mean and in the 95th percentile. Northern DRC also had maximum temperatures in the 99th percentile during December. Annual minimum temperatures were above normal across the region (Fig. 7.24b). Departures from normal were highest in northeastern DRC, CAR, and northern Cameroon. Minimum temperatures were above normal from January to May, above the 95th percentile in most areas, and were generally normal to below normal from June through November. In December, minimum temperatures were $+2^{\circ}$ to $+3^{\circ} \mathrm{C}$ above normal in the northern sector encompassing CAR, Cameroon, and southern Chad to end the year.

\section{(II) PRECIPITATION}

The climate of Central Africa exhibits seasonality at both the north and south ends of the region. The rainfall pattern is closely related to the north-south movement of the peak convective zone. Rainfall is unimodal in the northern areas of the region and marked with dry conditions during the NH autumn, winter, and spring months of November through April and a return to the rains during the NH summer. The southern areas of the region are dry during the NH summer months and wet during the $\mathrm{NH}$ autumn through winter and early spring seasons. The central areas of the region around the equator receive rainfall year-round. The area of maximum annual rainfall is located along coastal Cameroon, with totals exceeding $2000 \mathrm{~mm}$. On average, rainfall amounts range from $1200 \mathrm{~mm}$ over the southern tip of DRC and the southern areas of CAR and Cameroon to $2000 \mathrm{~mm}$ across much of DRC, Congo, Gabon, and southern Cameroon (Fig. 7.25a). Annual rainfall totals are generally lower over southern Chad with a steep north-south gradient indicated by about $200 \mathrm{~mm}$ rainfall amounts in the central areas of Chad to about $1000 \mathrm{~mm}$ in the southern tip (Fig. 7.25a).

During 2020, three areas of maximum annual rainfall over southwestern Cameroon and northcentral DRC emerged with totals exceeding $2000 \mathrm{~mm}$ (Fig. 7.25a). Most areas in northern DRC received rainfall near $2000 \mathrm{~mm}$, while totals ranged from 500 to $1500 \mathrm{~mm}$ in the south-north 

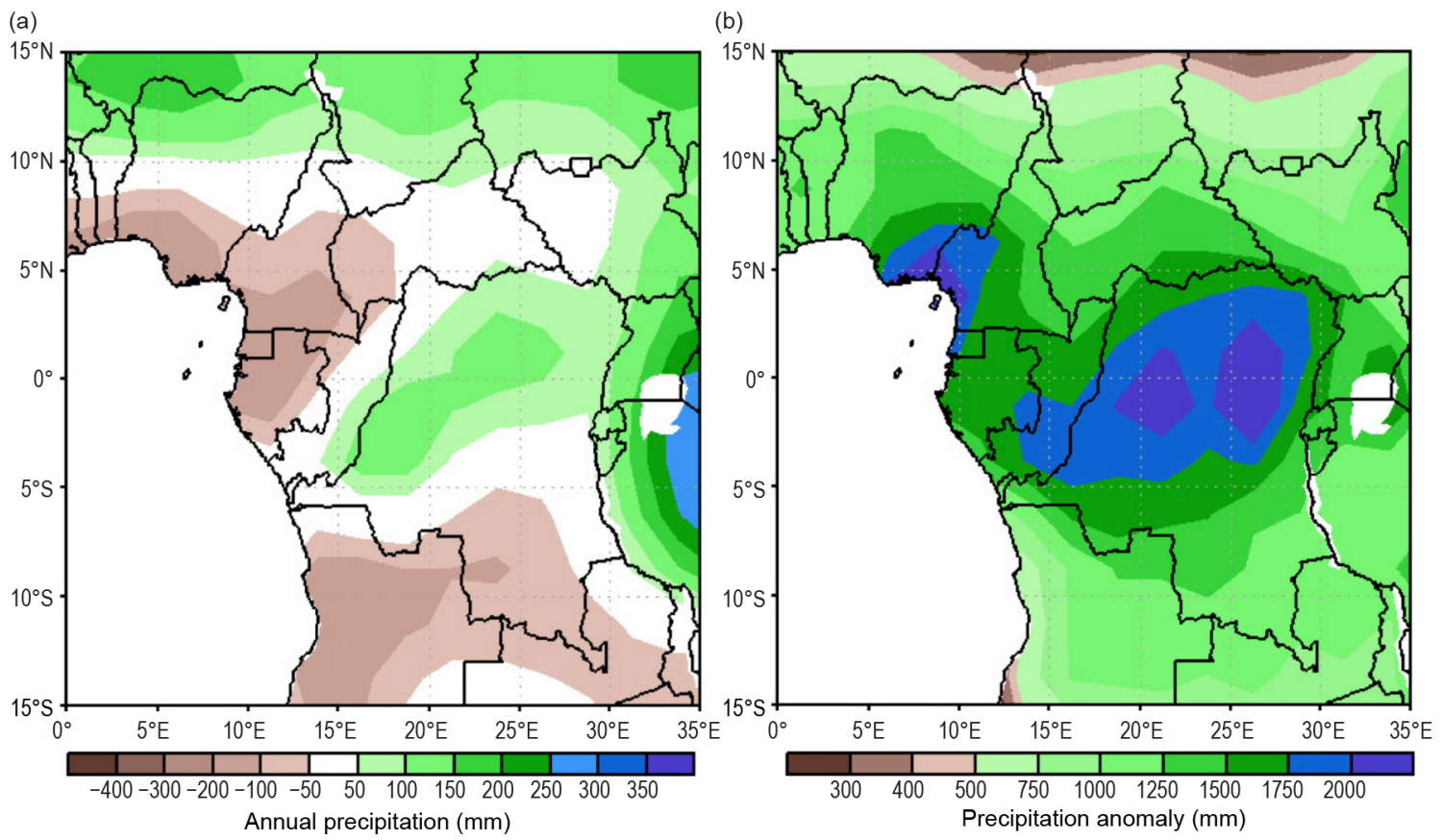

Fig. 7.25. Annual (a) cumulative precipitation $(\mathrm{mm})$ and (b) precipitation anomalies ( $\mathrm{mm}$ ) for Central Africa. 1981-2010 base period. (Source: NOAA/NCEP.)

direction from southern to northern DRC and in the north-south direction from southern Chad to northern DRC and Congo. Rainfall was below normal over western CAR, the southern half of Cameroon, Equatorial Guinea, and much of Gabon, with deficits of 100 to $200 \mathrm{~mm}$ (Fig. 7.25b). Annual totals ranked below the 5th percentile along the border between CAR and Cameroon, making 2020 the third-driest year since the start of the record in 1979. Part of the northern DRC observed rainfall about 100-200 mm above normal, placing this area above the 70th percentile. Tshopo Province in northern DRC recorded its second-highest rainfall amount since 1979.

Rainfall was significantly below normal over much of Cameroon and western CAR during the $\mathrm{NH}$ summer, with deficits reaching $150 \mathrm{~mm}$ in August, in the 5th percentile, making August 2020 one of the driest in this area on record. Rainfall was also below normal over the southern areas of DRC during the NH winter with a 5th-percentile ranking for the January-March period. Totals averaged 300-500 mm, with rainfall deficits more than $150 \mathrm{~mm}$ below the mean. Rainfall was much above normal in Chad during July-September, with departures from the mean exceeding $150 \mathrm{~mm}$ and above the 80th percentile. A similar pattern prevailed in the central sector of the region during the $\mathrm{NH}$ autumn, with areas in east central DRC near the Rwandan border registering about $1000 \mathrm{~mm}$ during October-December. The month of November contributed about $500 \mathrm{~mm}, \sim 150 \mathrm{~mm}$ above the mean and in the 95th percentile, making this month one of the wettest Novembers in the historical record.

\section{(III) NOTABLE EVENTS AND IMPACTS}

Heavy rainfall exceeded $135 \mathrm{~mm}$ in the South Kivu Province, eastern DRC, during 16-17 April according to the NOAA/CPC satellite rainfall estimates version 2 (RFE2). This deluge triggered extensive flooding, affecting nearly 75,000 people with 40 fatalities and 6000 households displaced, according to the U.S. Agency for International Development.

About $100 \mathrm{~mm}$ of rain on 1 October soaked the town of Sake near Lake Kivu in the North Kivu Province of eastern DRC, causing severe flooding and overflowing banks of the Mutahyo River. The provincial government reported at least 11 fatalities, with houses washed away and school and health buildings damaged. Bridges were destroyed and roads washed out, cutting connections between Sake and the provincial capital, Goma. 
Heavy rainfall exceeding $120 \mathrm{~mm}$, accompanied by strong winds, on 30 November led to severe flooding in the city of Mbanza-Ngungu in Kongo-Central Province in DRC, causing 13 fatalities and several more injuries, along with destroyed or severely damaged homes.

4) East Africa-L. Chang'a, E. Bekele, W. M. Thiaw, C. Mutai, A. Teshome, P. Nying'uro, J. Sebaziga, H. Mtongori, R. Barakiza, P. King'uza, and L. Nyembo.

East Africa, or the Greater Horn of Africa (GHA), spans the equator and extends between $10^{\circ} \mathrm{S}-$ $20^{\circ} \mathrm{N}$ and $20^{\circ}-50^{\circ} \mathrm{E}$. Its northern sector comprises Sudan, South Sudan, Ethiopia, Eritrea, Djibouti, and the northern two-thirds of Somalia. Southern Somalia, Kenya, northern Tanzania, Uganda, Rwanda, and Burundi are in its equatorial sector, while the southern sector encompasses central and southern Tanzania. The region has a complex terrain, with elevation ranging from about $160 \mathrm{~m}$ below sea level at Ethiopia's northern exit of the Rift Valley to more than $5000 \mathrm{~m}$ above sea level at glaciated Mount Kilimanjaro. The complex topographical features of the region are further typified by the presence of large lakes (e.g., Lake Victoria). The complex topography coupled with large-scale forcing factors including the peak moist convective zone (traditionally referred to as the intertropical convergence zone), ENSO, and Indian Ocean dipole are largely responsible for stronger spatial and temporal variability of climate patterns. The lower-latitude regions, including Kenya, Uganda, southern Ethiopia, and southern parts of Somalia and northern Tanzania, experience two rainy seasons during March-May (MAM) and October-December (OND). Central, western, and northern Ethiopia, Sudan, and South Sudan have a single dominant rainy season during June-September (JJAS). Central and southern Tanzania experiences a single dominant rainy season during November-April.

\section{(I) TEMPERATURE}

Annual mean temperatures over much of the Sudan, Somalia, Djibouti, Eritrea, and parts of eastern Ethiopia exceeded $30^{\circ} \mathrm{C}$, while annual mean temperatures over most of central Ethiopia were less than $22^{\circ} \mathrm{C}$ (Fig. 7.26a). However, anomalously higher mean annual temperatures were observed western Ethiopia, Kenya, and Uganda (Fig. 7.26a). Annual mean maximum temperatures reached $42^{\circ} \mathrm{C}$ locally in eastern Sudan and ranged between $35^{\circ} \mathrm{C}$ and $40^{\circ} \mathrm{C}$ in other parts of the country. Eastern Kenya and much of Somalia, Djibouti, and Eritrea had annually averaged maximum temperatures between $35^{\circ} \mathrm{C}$ and $38^{\circ} \mathrm{C}$, while it was less than $30^{\circ} \mathrm{C}$ over western Ethiopia and in the Lake Victoria region.

Meteorological station data indicate that most of the region experienced above-normal temperatures; Addis Ababa Bole International Airport in Ethiopia, for example, reported an annual temperature that was $1.3^{\circ} \mathrm{C}$ above normal (Fig. 7.26b). Overall, the mean annual temperature for East Africa exhibits a warming trend, with 2020 tied with 2017 as the third-warmest year on record (Fig. 7.26c). Spatially, the annual mean temperature was among the top 5\% warmest since 1981 over several locations, including South Sudan, much of Ethiopia, Uganda, and Kenya (Fig. 7.26b).

Anomalously warm temperatures were observed across most of the region between March and December 2020, being most pronounced in central and northern Ethiopia. During DecemberFebruary (DJF) 2019/20 and JJAS, mean temperatures were below normal over southern Sudan, northern South Sudan, and northeastern and southeastern Ethiopia. Temperatures were above normal in western Ethiopia extending southward into the Lake Victoria region, including western Kenya, Uganda, Rwanda, Burundi, and western Tanzania. Temperatures were above normal over much of East Africa during MAM and OND. These observations indicate a non-uniform temperature dynamic in the region during 2020 that may be driven in part by complex and diverse topographical features.

Maximum temperatures were above normal over much of the region, with the highest anomalies located over western areas of Ethiopia and Kenya along the borders of Uganda, South Sudan, and Sudan. The lowest annual mean minimum temperatures (Tmin) of 2020 were observed over 

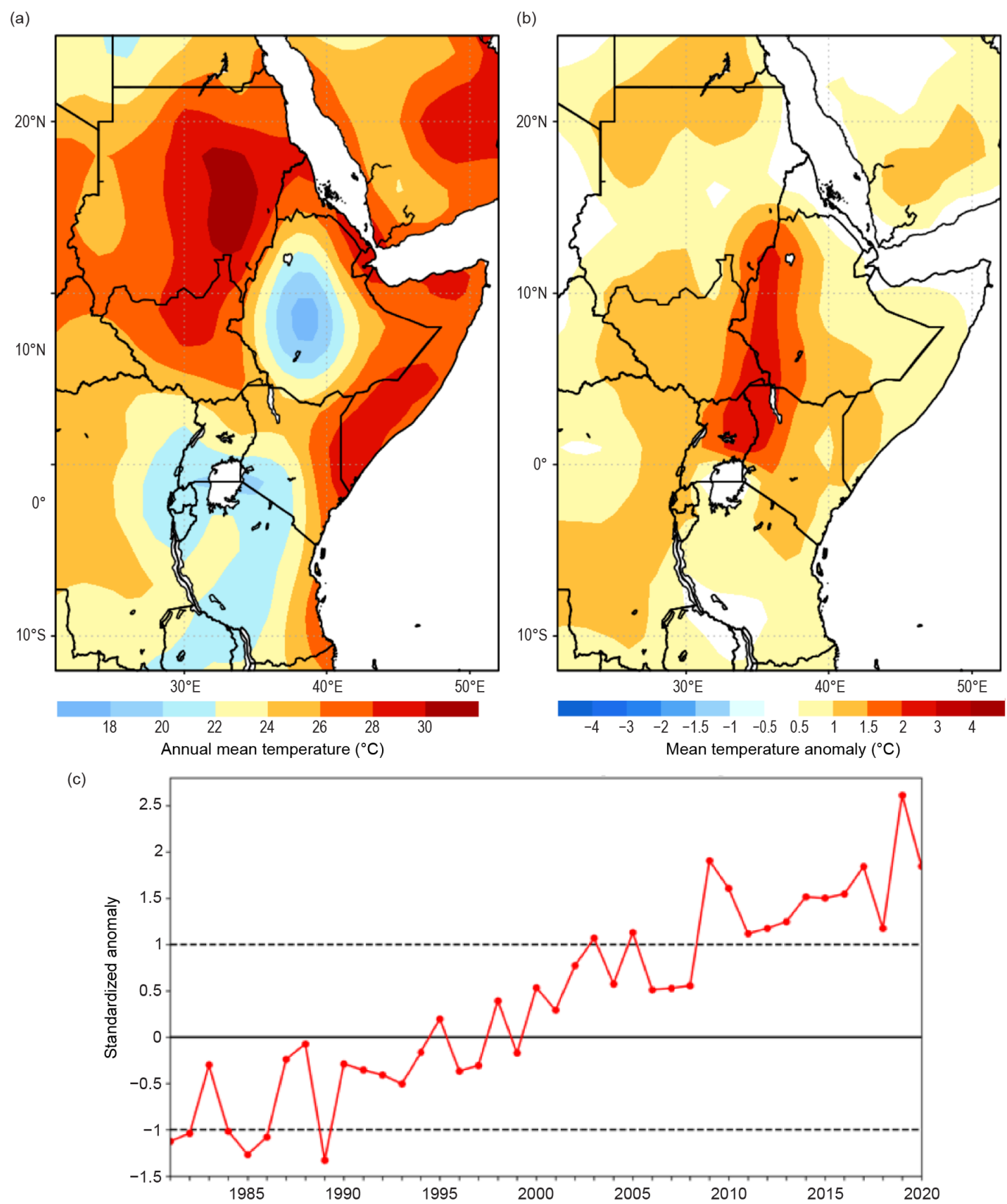

Fig. 7.26. Annual (a) mean temperature $\left({ }^{\circ} \mathrm{C}\right)$ and (b) mean temperature anomalies $\left({ }^{\circ} \mathrm{C}\right)$ for East Africa. $1981-2010$ base period. (c) Annual standardized temperature anomaly time series for the period 1981-2020. (Sources: NOAA/NCEP and NOAA CPC.)

western Ethiopia $\left(<8^{\circ} \mathrm{C}\right)$ and were between $10^{\circ} \mathrm{C}$ and $20^{\circ} \mathrm{C}$ across much of the rest of Ethiopia, southern Uganda and Kenya, and much of Tanzania, except for the coastline (not shown). Mean Tmin were $20^{\circ}-25^{\circ} \mathrm{C}$ over much of eastern Sudan, South Sudan, and Somalia. Overall, the Tmin was above normal across the region.

\section{(II) PRECIPITATION}

Annual rainfall surpassed $1000 \mathrm{~mm}$ across western Ethiopia, portions of South Sudan, much of Uganda, Rwanda, Burundi, western Kenya, and much of Tanzania (Fig. 7.27a). Central and eastern Kenya, central Ethiopia, southern Sudan, and northern South Sudan received rainfall between $600 \mathrm{~mm}$ and $1000 \mathrm{~mm}$. Totals were less over northern Sudan, Eritrea, Djibouti, and northern Somalia, with rainfall estimates ranging between $50 \mathrm{~mm}$ and $600 \mathrm{~mm}$. Rainfall was significantly above normal over eastern Tanzania, southwestern Kenya, where surpluses exceeded $300 \mathrm{~mm}$ (Fig. 7.27b). Rainfall was above normal over much of southern and northwestern Kenya and portions of east central Sudan, with totals averaging 150-300 $\mathrm{mm}$ above the mean in eastern 
(a)

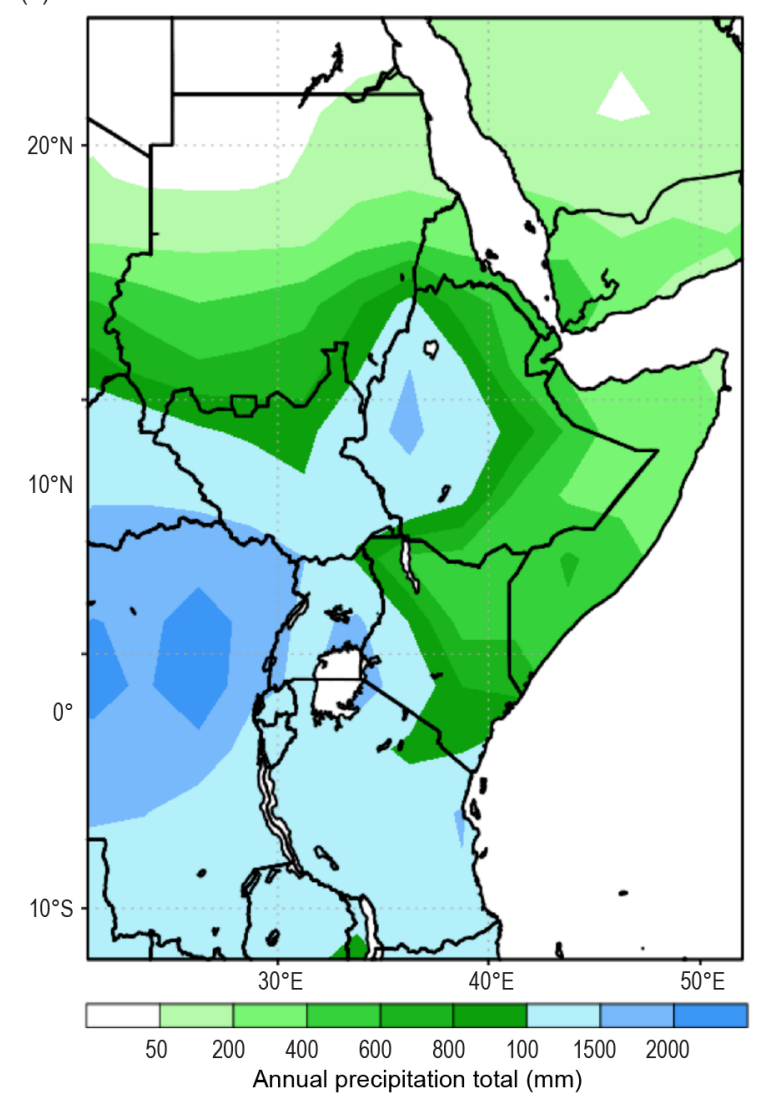

(b)

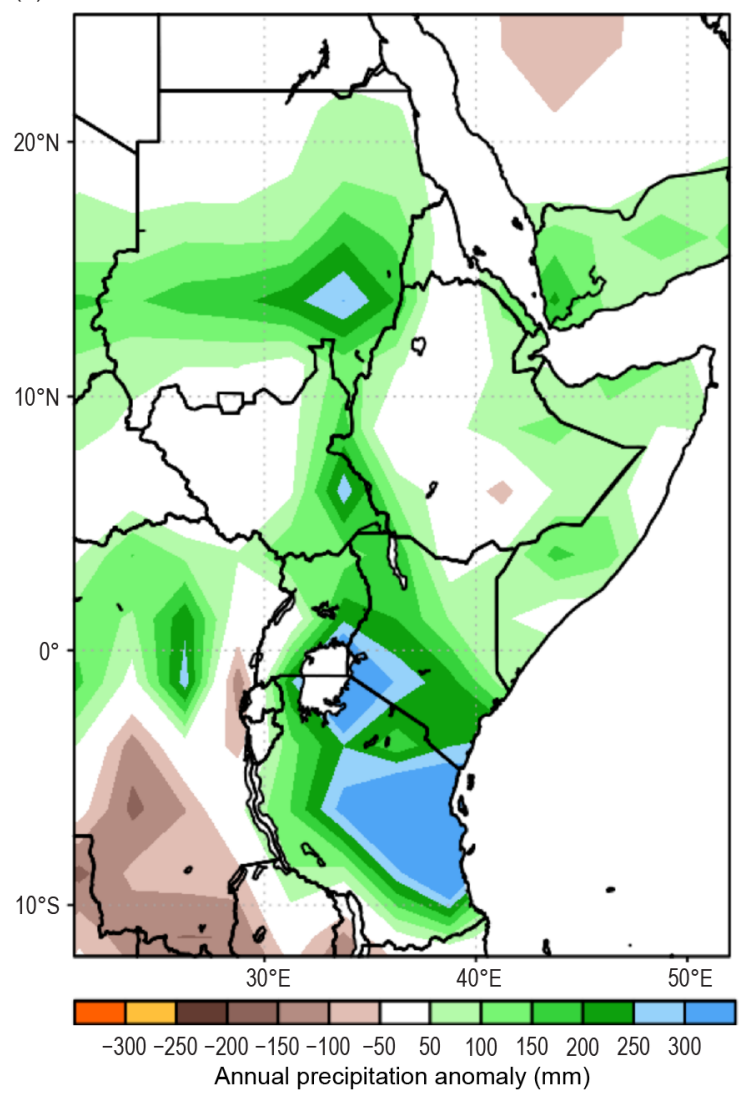

Fig. 7.27. Annual (a) cumulative precipitation $(\mathrm{mm})$ and $(\mathrm{b})$ precipitation anomalies $(\mathrm{mm})$ for East Africa in 2020. 1981-2010 base period; GPCP data. (Source: NOAA/NCEP.)

Uganda and southeastern Sudan. The climatologically drier areas of Somalia, Djibouti, eastern Eritrea, and northern Sudan registered 50-100 mm above the mean. Annual rainfall amount exceeded the 90th percentile over central Tanzania, southwestern Kenya, and much of Sudan. Overall, 2020 was the wettest in the historical record since 1981 in the Lake Victoria region, with totals exceeding 1.5 standard deviations above the mean.

Most of the region recorded normal to above-normal rainfall during all seasons; excessive rainfall was more pronounced during MAM over Burundi, Kenya, Rwanda, Uganda, and Tanzania (not shown). Most of Burundi and Kenya recorded 125\%-150\% of their long-term means during MAM, while Addis Ababa Bole (Ethiopia) recorded $140 \%$ of its normal. Some parts of northwestern Kenya, particularly around Turkana County, recorded more than $200 \%$ of its long-term mean precipitation. In Rwanda, both MAM and OND rainfall seasons were relatively higher than the long-term average for most observing stations. In Tanzania, observed rainfall was 150\%-175\% of normal during November-April and 125\%-150\% of normal during MAM. Higher rainfall totals exceeding $175 \%$ of the long-term average were observed over central and some parts of southwestern Tanzania. Rainfall was also much above normal over Sudan during JJAS, with anomalies exceeding $200 \mathrm{~mm}$ locally in the southeast near the border with Ethiopia; rainfall totals across the eastern and central sectors of the Sudan were among their highest (top 5\%) since the start of the record in 1981 (Fig. 7.27b).

\section{(III) NOTABLE EVENTS AND IMPACTS}

On 23 March, $122.5 \mathrm{~mm}$ of rainfall was recorded at the Kilwa meteorological station in Tanzania, the highest on record in this station for the month of March and second highest on record since its record began in 2005. Nearly all dams that supply hydroelectric power in Tanzania were flooded beyond their water-holding capacity such that they were forced to discharge. 
April brought extremely heavy rains to East Africa. The most severe downpours occurred during 14-20 April and triggered widespread flooding and landslides in Ethiopia, Somalia, Rwanda, and Burundi. According to NOAA/CPC satellite RFE2, rainfall totals exceeded $160 \mathrm{~mm}$ in portions of Rwanda and Burundi during this 7-day period, with more than $200 \mathrm{~mm}$ recorded over northern Rwanda. The U.S. Embassy in both countries declared a state of emergency. According to U.S. Agency for International Development and the Government of Rwanda Ministry of Emergency Management, the floods destroyed more than 2000 houses and more than 3500 ha of crops. An estimated 62,300 people were in need of immediate food assistance. There were 113 fatalities and more than 100 injuries due to the extreme rains. In western Burundi, the floods resulted in an overflow of the Ruzizi River, affecting an estimated 45,000 people. Over southern Ethiopia and southern Somalia, rainfall totals during the same period exceeded $200 \mathrm{~mm}$, resulting in flooding with eight fatalities and infrastructural damage, especially in the Gamo region of southern Ethiopia.

On 27 April, $80 \mathrm{~mm}$ of rain led to flash flooding that swept through the city of Qardho (also known as Gardo) in the northeastern Bari region of Somalia. At least six fatalities were reported, while hundreds of families lost their homes.

During 2020, extreme events including floods, heavy rainfall, and landslides led to a total of 341 fatalities and more than 13,500 damaged houses in Rwanda, while 7000 houses were damaged and more than 50,000 people were displaced in Burundi. During the OND rainy season in Kenya, there were approximately 300 fatalities and more than 150,000 households were affected due to heavy rainfall and flooding. During the JJAS rainfall season in Ethiopia, more than one million people were affected and nearly 300,000 were displaced due to flooding. In Tanzania, 40 deaths and the destruction of more than 2450 houses were reported due to heavy rainfall and flooding. Similarly, the overflow of the Nile River in Khartoum and the surrounding areas in the Sudan caused extensive damage in property and loss of lives. Elagib et al. (2021) reported that the 2020 floods in the Sudan caused the loss of 417 human lives and affected up to two million people. The flood was associated with heavy rainfall over Ethiopia and upstream Nile basin countries (Elagib et al. 2021).

A widespread desert locust infestation from 2019 into 2020 impacted the equatorial and northern sectors of East Africa, as heavy rains and prevailing winds were favorable for breeding and movement across the region. A large swarm of locusts spread across 14 Kenyan counties and later spread into Ethiopia, northeastern Somalia, Uganda, and South Sudan, while some groups reached parts of northern Tanzania. The massive infestation resulted in significant crop damage across eastern Africa. According to an early assessment by the UN Food and Agriculture Organization, desert locusts caused the destruction of nearly 200,000 ha of cropland and more than 1.2 million ha of pasturelands, as well as the loss of more than 350,000 metric tons of cereal, resulting in one million people in need of food aid in Ethiopia. The World Bank estimated that locust-related losses, including damage to crops, livestock, and other assets, may be as much as $\$ 8.5$ billion (U.S. dollars) for the East Africa region and Yemen.

5) Southern Africa-A. C. Kruger, C. McBride, M. Robjhon, and W. M. Thiaw

Southern Africa comprises the sub-region located to the south of $5^{\circ} \mathrm{S}$ and includes Angola, Namibia, Zambia, Botswana, Zimbabwe, Malawi, South Africa, Lesotho, Eswatini, and Mozambique. The region has two main seasons-the wet season, which spans from November of the previous year to April, and the dry season, which lasts from May to October.

\section{(I) TEMPERATURE}

Annual mean temperatures were above normal over the northeastern region, with anomalies of about $+0.5^{\circ}$ to $+1^{\circ} \mathrm{C}$ across eastern Zambia, northern Zimbabwe, Malawi, and northern Mozambique. According to the historical record since 1979, annual temperatures ranked above the 90th percentile in central Zambia, northern Zimbabwe, and northern Mozambique. In contrast, 
near- to below-normal temperatures dominated the western and central sectors, including southern Angola, northern Namibia, Botswana, and parts of central South Africa. Southern Angola and northwestern Namibia reported negative anomalies between $-1^{\circ} \mathrm{C}$ and $-2^{\circ} \mathrm{C}$; this was below the 5 th percentile in northwestern Namibia.

Annual maximum temperatures were above normal over northeastern Angola, Zambia, Malawi, northern Mozambique, and parts of western South Africa and southern Mozambique (Fig. 7.28a), while the annual minimum temperature was $0.5^{\circ}$ to $2.5^{\circ} \mathrm{C}$ below normal over southern Angola and northern Namibia (Fig. 7.28b). South Africa reported its fifth-warmest year in the 70year record, about $0.5^{\circ} \mathrm{C}$ above normal, based on the data of 26 climate stations (Fig. 7.28c). South Africa is warming at an average rate of $+0.16^{\circ} \mathrm{C}$ per decade, statistically significant at the $5 \%$ level.

During DJF 2019/20, mean temperatures were above normal over northern Angola, central Zambia, Zimbabwe, northeastern South Africa, and western and southern Mozambique (not shown). Belownormal temperatures were observed over Botswana and central South Africa. While the average maximum temperature was well below normal over Botswana and central South Africa, it was above normal over a wide area extending from Angola and eastern Namibia eastward to Mozambique.

(a) Maximum temperature



(b) Minimum temperature



(c)



Fig. 7.28. Annual (a) maximum and (b) minimum temperature anomalies ( ${ }^{\circ} \mathrm{C}$; CDAS data). (c) Annual temperature anomaly time series $\left({ }^{\circ} \mathrm{C}\right)$ for the period 1951-2020. Red line indicates linear trend. (Sources: NOAA/NCEP and South African Weather Service.) 
During MAM, above-normal temperatures persisted over northern Angola, Zambia, eastern Zimbabwe, Malawi, and parts of northern and southern Mozambique (not shown). During the dry and cold season of JJA, mean temperatures averaged well below normal, with negative anomalies of more than $-1.5^{\circ} \mathrm{C}$ across Angola, northern Namibia, and central South Africa (not shown).

Early during September-November (SON) season, well above-normal temperatures returned over eastern Zambia, Malawi, northern Zimbabwe, and northern Mozambique, while belownormal temperatures lingered in southern Angola and western Namibia (not shown). Maximum temperatures ranked above the 99th percentile over southeastern Zambia, Malawi, and northern Mozambique.

\section{(II) PRECIPITATION}

Annual rainfall totals near or above $1000 \mathrm{~mm}$ were reported over the northern sector, while accumulations of less than $600 \mathrm{~mm}$ were observed across the western region during 2020 (Fig. 7.29a). Rainfall for the year was below normal across much of southern Africa, including Angola, central Zambia, Malawi, northern Mozambique, and western and eastern South Africa, Eswatini, and southernmost Mozambique (Fig. 7.29b). In contrast, annual rainfall was above normal over the central sector, including Botswana, Zimbabwe, and central South Africa. Large rainfall deficits exceeding $250 \mathrm{~mm}$ were observed over northeastern Mozambique (Fig. 7.29b). Conversely, surpluses surpassed $250 \mathrm{~mm}$ over northeastern Botswana and western Zimbabwe, ranking between the 95th and 99th percentiles, based on the 42-year record.

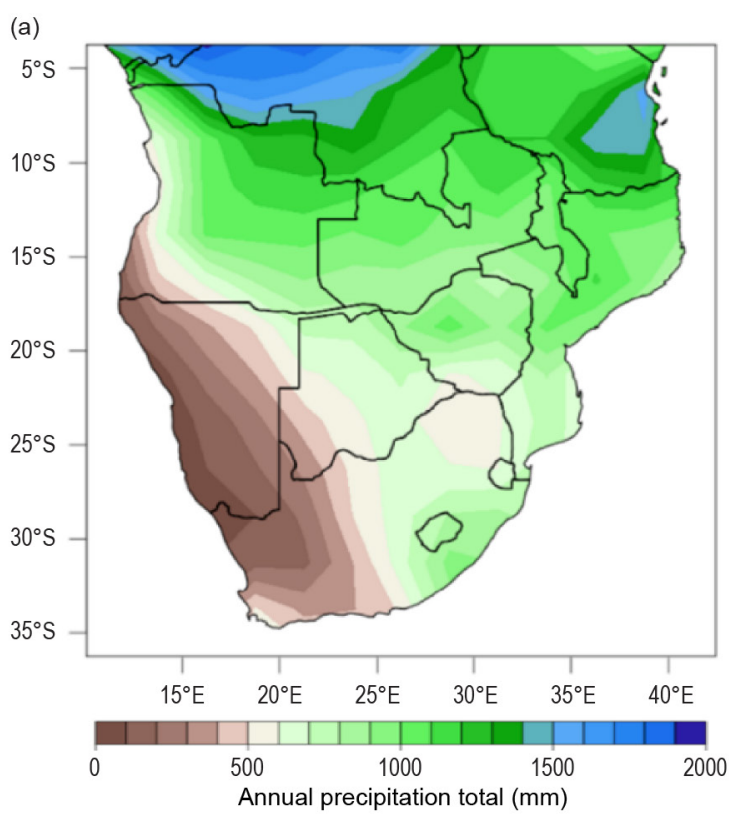

(c)

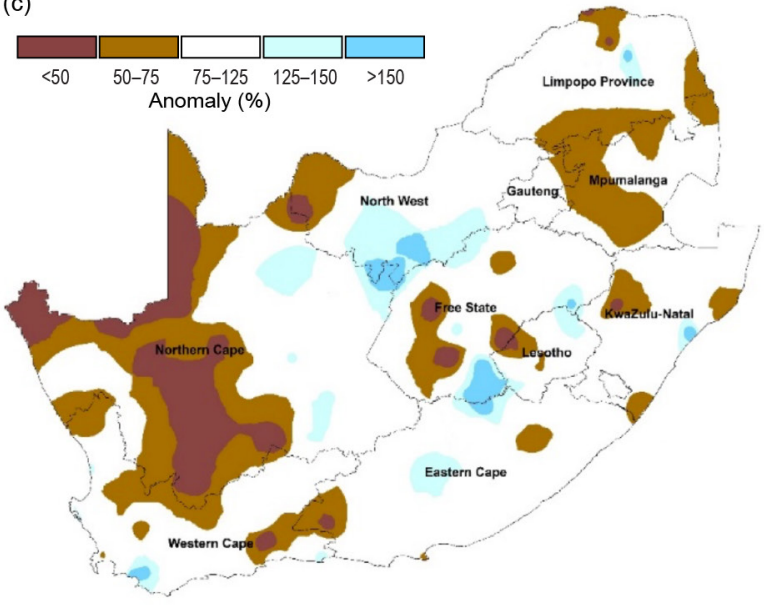

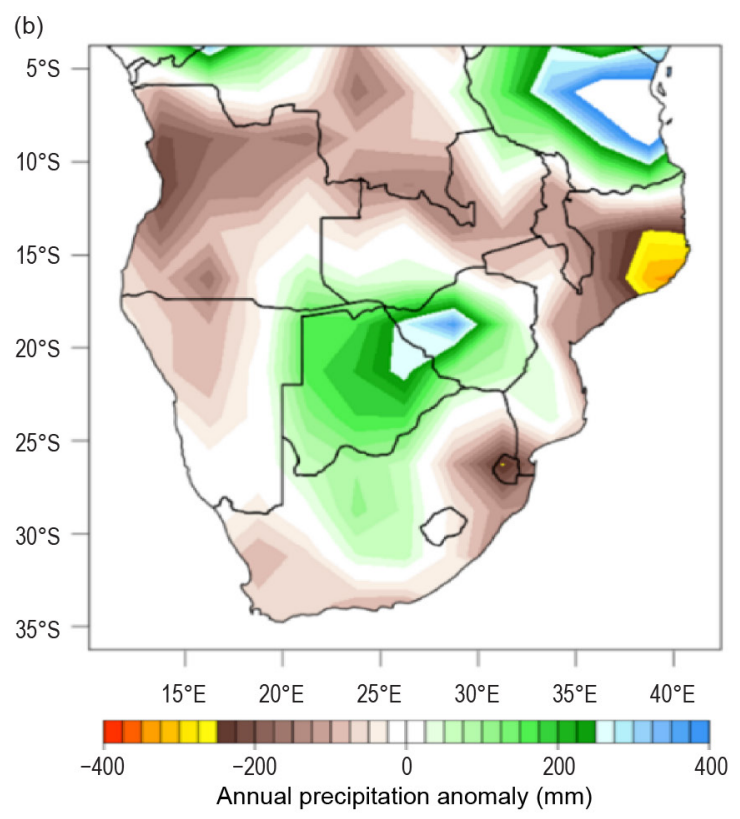

Fig. 7.29. Annual (a) rainfall totals $(\mathrm{mm})$ and (b) rainfall anomalies $(\mathrm{mm})$. Departures from the 1981-2010 climatology for southern Africa. GPCP data. (c) Annual rainfall anomalies (\% of normal) across South Africa. (Sources: NOAA/NCEP and South African Weather Service.) 


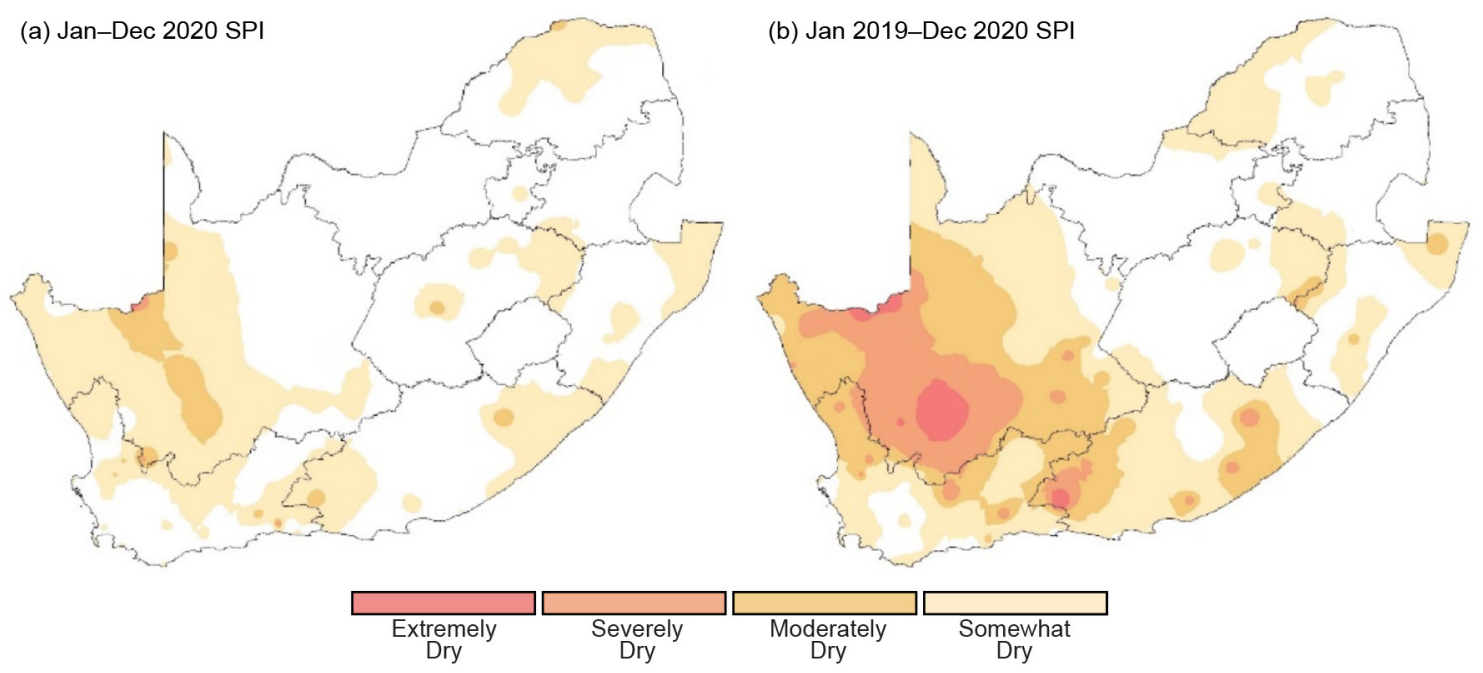

Fig. 7.30. (a) 12-month and (b) 24-month SPI maps for South Africa ending Dec 2020 (Source: South African Weather Service).

The most significant feature of the rainfall during 2020 in South Africa was the persisting dry conditions in western South Africa, with a substantial region receiving less than $50 \%$ of its normal precipitation (Fig. 7.29c; see also Notable events and impacts). The central interior also shows isolated areas that remained dry. However, the area of South Africa experiencing drought decreased over the year, where some regions received adequate precipitation in the early austral summer rainy season of 2020/21. The remainder of the country received near-normal rainfall. No significant area of the country received substantially above-normal rainfall, except for southern parts of the North-West Province. The 12-month standardized precipitation index (SPI; Fig. 7.30a) for South Africa ending December 2020 indicates that the western interior was somewhat to moderately dry in places; however, the 24-month SPI (Fig. 7.30b) shows that the long-term effects of the drought persist, with extensive regions showing moderate to severely dry conditions over the last 2 years.

During DJF, wetter-than-normal conditions were experienced over western Angola, Botswana, central and northern South Africa, Malawi, and northern Mozambique (not shown), while belownormal rainfall extended over Zambia and northern Zimbabwe to central Mozambique.

During MAM, wetter-than-normal conditions persisted over Botswana, western Zimbabwe, and central South Africa. In contrast, drier-than-normal conditions developed over Angola, Malawi, and Mozambique (not shown). Seasonal accumulation was so low over Malawi and northern Mozambique that rainfall totals were below the fifth percentile.

During the dry season of June-August, rainfall was near normal over much of the region; however, below-normal rainfall was received over Lesotho and southeastern South Africa (not shown). Seasonal rainfall ranked between the fifth and 10th percentiles across central and southern South Africa, suggesting that midlatitude systems likely failed to bring winter moisture into the region. By SON, while near-normal rainfall dominated over much of southern Africa, abovenormal rainfall returned over Botswana, southeastern Angola, and southwestern Zambia (not shown). Total rainfall ranked between the 90th and 95th percentiles in northwestern Botswana and southeastern Angola. Conversely, below-normal rainfall re-emerged over southeastern Zambia, northern Zimbabwe, southern Malawi, northern Mozambique, eastern South Africa, Eswatini, and southernmost Mozambique.

\section{(III) NOTABLE EVENTS AND IMPACTS}

Dry conditions persisted over large parts of western South Africa during 2020 including some areas where dryness has prevailed for about 7 years. The year began with dry conditions persisting in most parts of the western interior, with above-normal temperatures in the central parts exacerbating the dryness. The Northern Cape was declared a disaster area after drought impacted 
the province. A total of 200 million rand ( $\$ 14$ million U.S. dollars) was set aside to help address the crisis. KwaZulu-Natal Province was also impacted by a shorter-term drought, accompanied by high temperatures, that affected 256 towns and surrounding communities. The most impacted areas include Uthukela, Umzinyathi, Amajuba, Zululand, Uthungulu, and Umgungundlovu districts. Adequate rain fell in the southern and northeastern parts of the country, although some associated severe storms caused extensive damage to infrastructure. By February, above-normal rainfall spread to the central and southeastern interior, but the late-summer rainfall ended abruptly, followed by drier conditions in March. Severe storms were reported in February with extensive damage, especially in the Gauteng and Eastern Cape Provinces. In April some areas received more than twice their normal amounts over the eastern half of South Africa. Localized flooding was reported in several places. Many flooding events occurred during austral summer and autumn. Based on NOAA's CPC RFE2, Gauteng Province received 100-300 mm of precipitation during 4-10 December 2019, which led to flooding in many parts of the Province on 11 December, affecting 3500 people with two fatalities reported, according to the Emergency Events Database (EM-DAT). During 7-10 February, RFE2 estimated $90 \mathrm{~mm}$ of precipitation, again in Gauteng, that caused flash floods, leading to three fatalities and affecting 200 people.

According to the Southern African Science Service Centre for Climate Change and Adaptive Land Management, upstream areas, such as Onjiva in southern Angola, recorded cumulative rainfall totals of $263 \mathrm{~mm}$ from 26 February to 3 March, which triggered floods over many areas downstream of northern Namibia, including the Oshana, Oshikoto, Omusati, and Ohangwena Regions on 6 March, affecting 1000 people.

During 16-22 March, up to $150 \mathrm{~mm}$ of rain fell across northern Zambia, with the largest totals over the Luapula and parts of the Northern Provinces. These large rainfall totals resulted in flooding across 28 districts over the Northwestern, Copperbelt, Luapula, Northern, Muchinga, Eastern, Western, and Lusaka Provinces of Zambia, with an estimated 700,000 people affected, according to the Disaster Management and Mitigation Unit. During the same period, rainfall estimates approached $100 \mathrm{~mm}$ over southwest-central Angola, causing flooding and damages and affecting over 2000 families over the Cuanza Sul, Malanje, Lunda Sul, and Cunene Provinces of Angola, based on report from the Agência Angola Press.

Tropical Storm Chalane made landfall over the Muanza District in the Sofala Province of central Mozambique on 30 December, causing at least two fatalities and affecting nearly 11,000 people, according to the United Nations Office for the Coordination of Humanitarian Affairs. The impact was smaller over Zimbabwe as the system weakened into a tropical depression, with about 600 people displaced and minor infrastructure damages reported. In contrast, drought caused food shortage over Lesotho by the end of the year, affecting 766,000 residents, according to EM-DAT.

6) Western Indian Ocean island countries-G. Jumaux, M. Robjhon, W.M. Thiaw, R. Dhurmea,

M. L. Rakotonirina, and B. Andrade

The Western Indian Ocean island countries consist of Madagascar, Seychelles, Comoros, Mayotte (France), Réunion (France), Mauritius, and Rodrigues (Mauritius). With two distinct main seasons, western Indian Ocean islands generally experience a warm and wet period during November of the antecedent year to April and a cold and dry season during May-October. Overall, 2020 was warmer than normal (Fig. 7.31). Annual rainfall was above normal in Seychelles and Madagascar and below normal over the rest of the island countries (Fig. 7.31).

\section{(I) TEMPERATURE}

The annual mean temperature over Réunion Island (based on three stations) was $0.24^{\circ} \mathrm{C}$ above normal, the 15th highest since record keeping began in 1968. March and October, both $+0.8^{\circ} \mathrm{C}$ above normal (Fig. 7.32), were among the six warmest for their respective months, while the 
January maximum temperature and November minimum temperature were among the 10 coldest, at $-0.5^{\circ} \mathrm{C}$ below normal. The lowest minimum temperature $\left(-2.3^{\circ} \mathrm{C}\right)$ was recorded in the highlands at Plaine-des-Chicots on 11 August.

In Mauritius, the annual mean temperature (based on two stations at Vacoas and Plaisance) was slightly above normal for $2020\left(+0.51^{\circ} \mathrm{C}\right)$. Maximum temperatures were close to normal $\left(+0.18^{\circ} \mathrm{C}\right)$ while minimum temperatures were above normal $\left(+0.86^{\circ} \mathrm{C}\right)$. Mean temperatures were near normal for most of the austral summer months (anomaly $<+0.5^{\circ} \mathrm{C}$; Fig. 7.32), except March $\left(+0.7^{\circ} \mathrm{C}\right)$. Above-normal mean temperatures prevailed during the winter months from July to October. Mauritius experienced above-normal maximum and minimum temperatures in October, making this the warmest October since 1960.

In Madagascar, the mean temperature for 2020 (based on 18 stations) was $23.9^{\circ} \mathrm{C}$, which was $0.5^{\circ} \mathrm{C}$ above normal and the 10 th-warmest year since 1980 . The mean annual minimum and maximum temperatures were $19.3^{\circ} \mathrm{C}$ and $28.5^{\circ} \mathrm{C}$, respectively, $+0.6^{\circ} \mathrm{C}$ and $+0.4^{\circ} \mathrm{C}$ above normal. The cold settled and was marked in the central highlands. The minimum absolute temperature recorded was $2.0^{\circ} \mathrm{C}\left(-4^{\circ} \mathrm{C}\right.$ below normal) at Antsirabe on 28 July. The absolute maximum temperature of $42.9^{\circ} \mathrm{C}$ was recorded at Bezaha on 9 November $2020,+7.9^{\circ} \mathrm{C}$ above the monthly average.

In Mayotte (Pamandzi Airport), the annual temperature was the second highest in the 60 -year record, with an average temperature of $27.7^{\circ} \mathrm{C}\left(+0.9^{\circ} \mathrm{C}\right.$ above normal and $0.3^{\circ} \mathrm{C}$ below the record set the previous year in 2019). Seven consecutive months from January to July (Fig. 7.32) were each among their three warmest on record.

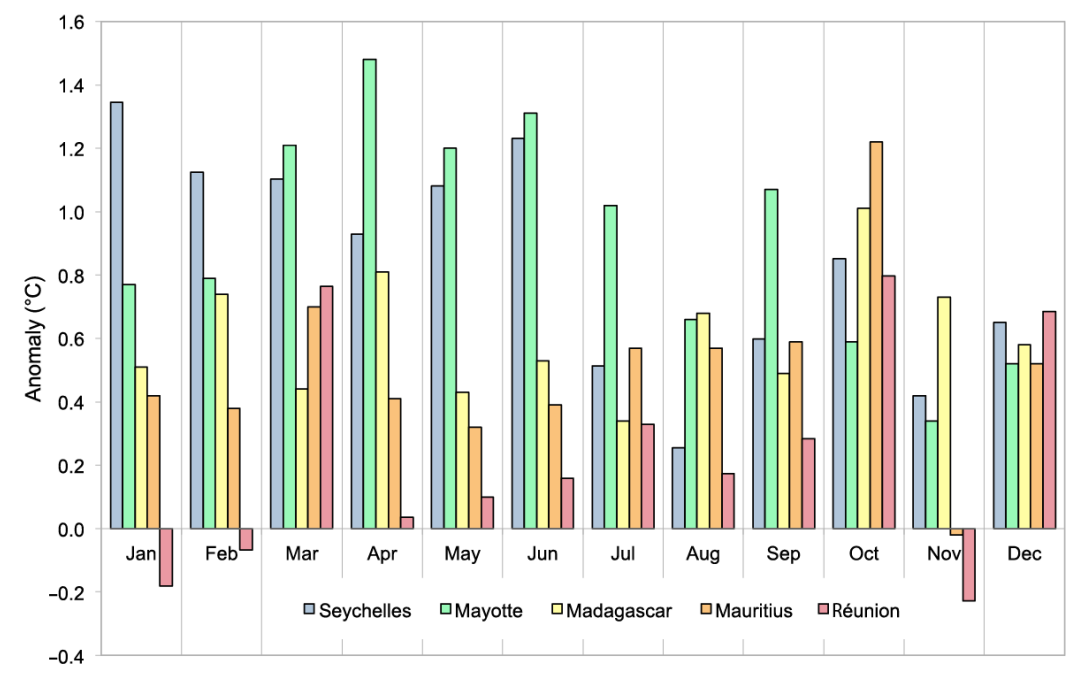

Fig. 7.32. Monthly mean temperature anomalies ( ${ }^{\circ} \mathrm{C} ; 1981-2010$ base period) for the Western Indian Ocean island countries in 2020. (Sources: Météo France; and Meteorological Services of Mauritius, Seychelles, and Madagascar.) 
At Seychelles International Airport, the annual mean temperature anomaly for 2020 was $+0.8^{\circ} \mathrm{C}$ above normal, which is the highest since records began in 1972, surpassing 2019 (Fig. 7.33). All months were above normal; January, March, and May each were the warmest on record. February, April, June, September, and October were each among their three warmest.

\section{(II) PRECIPITATION}

The annual rainfall total over Réunion Island was $72 \%$ of normal, making 2020 the third-driest year since 1972. North Réunion Island experienced deficits during the rainy season (December-April), while the rainfall over South Réunion

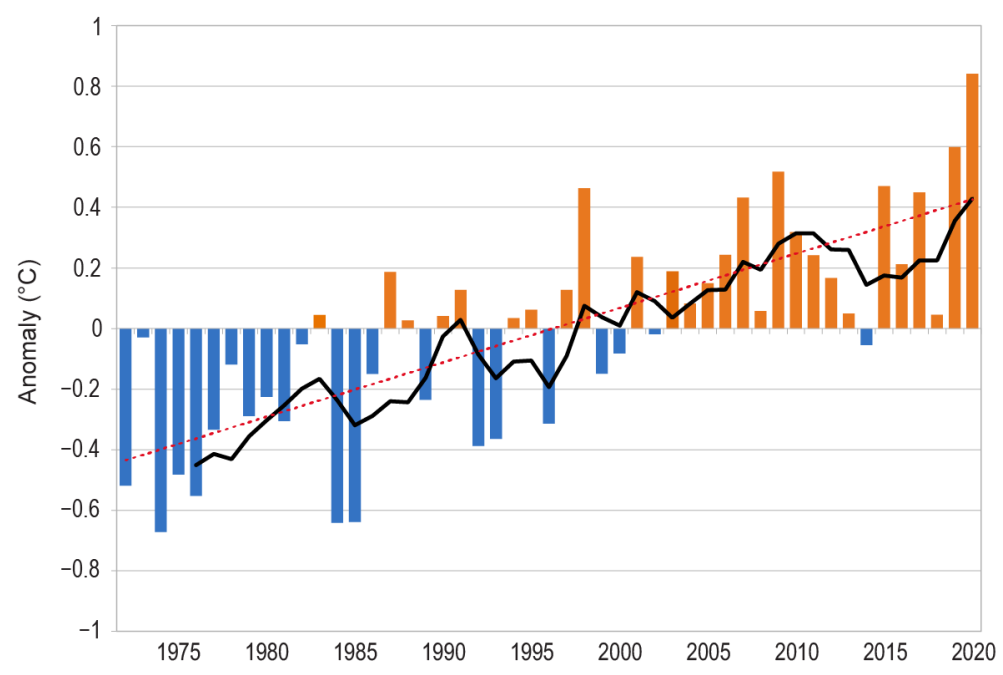

Fig. 7.33. Annual mean temperature anomaly time series $\left({ }^{\circ} \mathrm{C}\right.$; 1981-2010 base period) in Seychelles for the period 1972-2020. Black line is the 5-yr running mean and red line represents the linear trend. (Source: Seychelles Meteorological Service.) Island was adequate (except in February). The South received rainfall associated with Tropical Storms Calvinia in December 2019 and Diane in January 2020 (see section 4g6). The dry season (May-November) was the second driest on record, with $60 \%$ of normal precipitation, causing drought in 21 out of 24 localities. Some stations recorded their lowest annual rainfall since records began, notably in the towns of Saint-Denis, Le Port, and Salazie.

In Mauritius, the mean annual rainfall total was $1921 \mathrm{~mm}$, which was $96 \%$ of normal (average rainfall is $1999 \mathrm{~mm}$ ). Marked variability in rainfall from month to month (Fig. 7.34) was observed during (austral) summer, while all austral winter months had deficient rainfall except June. Winter 2020 tied with 2018 as the sixth-driest such season since the start of the record in 1904 and the second driest of the last decade.

Total annual rainfall in Madagascar (average of 18 stations) was $1698 \mathrm{~mm}$, which is $99.5 \%$ of normal. Spatially, however, the northern part of the island was wetter than normal while the southern part was drier (Fig. 7.35). January was the wettest month of the year. The highest annual amount compared to normal was observed in Antsohihy in the northwest, at 189\% of its normal precipitation. Associated with the evolution of Tropical Cyclone Herold (see section 4g6), the highest accumulated precipitation total within a 24-hour period in 2020 was $205.6 \mathrm{~mm}$ recorded in Sambava in the northeast on 17 March.



Fig. 7.34. Monthly rainfall anomalies (mm; 1981-2010 base period) in the Western Indian Ocean island countries in 2020. (Sources: Météo France; and Meteorological Services of Mauritius, Seychelles, and Madagascar.) 


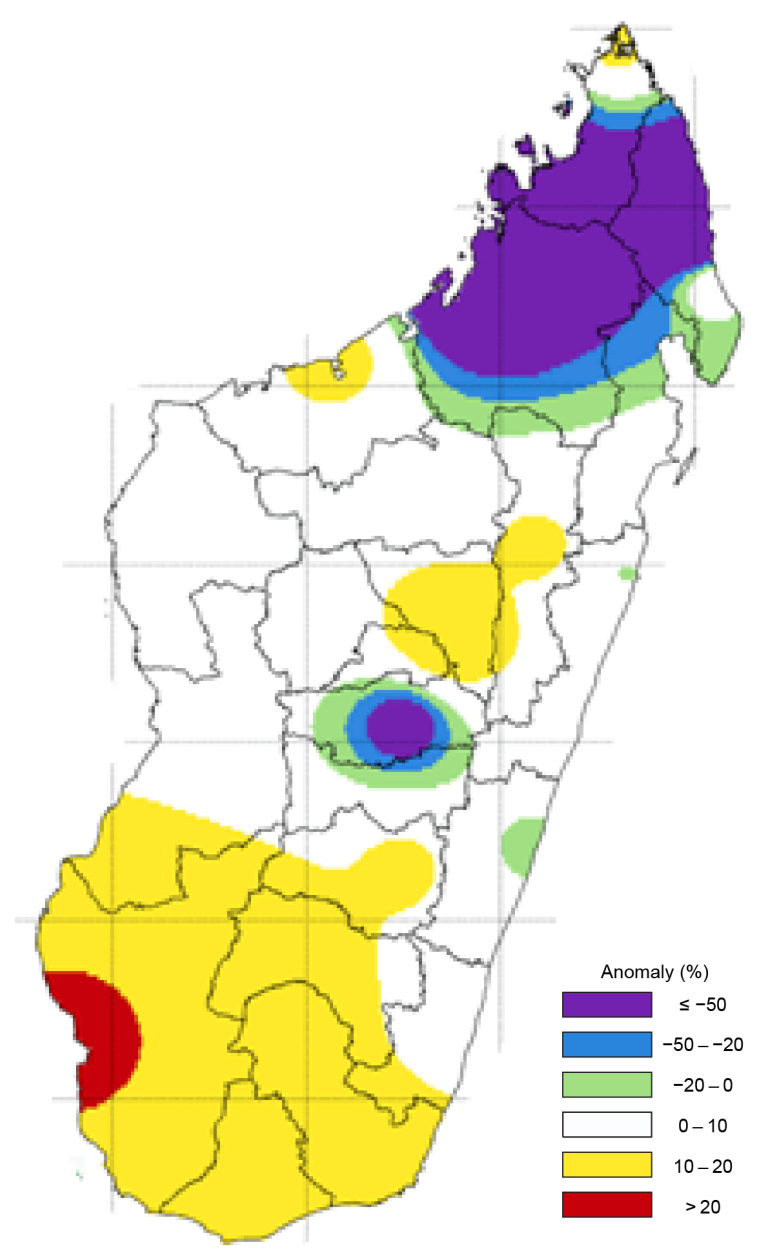

Fig. 7.35. Annual rainfall anomalies (\%; 1981-2010 base period) across Madagascar in 2020. (Source: Madagascar Meteorological Service.)

For Mayotte, the total annual rainfall (average of two stations) was $1288 \mathrm{~mm}$, which was $87 \%$ of normal. The total rainfall during the first half of the year was $77 \%$ of normal, the sixth driest of the 60-year record for this period, and 109\% of normal during the second half. April and August were among their five driest on record, while October was the third wettest.

In Seychelles, the annual rainfall total $(2803 \mathrm{~mm})$ was $118 \%$ of normal, making 2020 the sixthwettest year since the start of the record in 1972. July and November were each their wettest on record, contributing to the annual surplus.

\section{(III) NOTABLE EVENTS AND IMPACTS}

During November-April 2019/20, the southwest Indian Ocean basin experienced 10 tropical storms, of which six developed into tropical cyclones. Seven tropical cyclones and tropical storms made landfall and impacted the region. Five of these tropical systems affected Madagascar. Tropical Cyclone Belna made landfall in the Soalala District in the Boeny Region of western Madagascar on 9 December 2019, affecting about 3000 people, according to the National Office for Risk and Disaster Management (BNGRC). Tropical Storm Diane began as an incipient weather disturbance over the Mozambique Channel and tracked eastward to traverse Madagascar on 23 January. Portions of the Boeny and Sofia regions of western Madagascar received 1-day rainfall totals over $140 \mathrm{~mm}$, according to the RFE2.0. The BNGRC reported widespread flooding across the Alaotra Mangoro, Analamanga, Betsiboka, Boeny, Melaky, and Sofia regions. Reports indicate that 31 people were killed and more than 107,000 affected. The system intensified and was officially named as a tropical storm when it passed near Mauritius on 24 January. Tropical Storm Francisco made landfall in Mahanoro in eastern Madagascar on 15 February after moving near Mauritius as 
a deepening low-pressure system on 11 February. Tropical Cyclone Herold meandered near northeastern Madagascar on 14 March, bringing 1-day estimated precipitation totals of 120-140 mm over portions of Sambava and Antalaha. Herold caused severe flooding, with floodwaters up to $2 \mathrm{~m}$ in some areas, resulting in four deaths and over 3000 affected people across the Maroantsetra, Sambava, and Antalaha Districts, according to the disaster authorities. Toward the end of the year, Tropical Storm Chalane made landfall over the city of Fenoarivo Atsinanana in eastern Madagascar on 27 December. Although Toamasina station, located about $100 \mathrm{~km}$ farther south, recorded $351 \mathrm{~mm}$ of rainfall on 26 December, rains from Chalane resulted in localized flooding and minor damages only in the city, based on reports.

Over Mauritius, Tropical Cyclone Calvinia hugged right to the east of the island on 30 December 2019, closing the island's main airport and businesses. Tropical Storm Esami formed as a tropical depression to the east-southeast of Port Louis and moved eastward across the island with peak sustained winds at $83 \mathrm{~km} \mathrm{~h}^{-1}$ on 23 January.

\section{f. Europe and the Middle East-P. Bissolli, Ed.}

Throughout this section, 1981-2010 is the base period used for both temperature anomalies and precipitation percentages, unless otherwise specified. European countries conform to different standards applied by their individual national weather services. All seasons mentioned in this section refer to the Northern Hemisphere. More detailed information can be found in the Monthly and Annual Bulletin on the Climate in RA VI - European and the Middle East, provided by WMO RA VI Regional Climate Centre on Climate Monitoring (RCC-CM; http://www.dwd.de /rcc-cm). Anomaly information has been taken from Figs. 7.37-7.40 and aggregations of CLIMAT station data when national reports are not available. Appendix Table A7.1 at the end of this chapter provides a list of included countries and their lengths of record for both temperature and precipitation.

\section{1) Overview}

Based on the Global Historical Climate Network (GHCN) v4.0.1 dataset (Menne et al. 2018), Europe $\left(36^{\circ}-72^{\circ} \mathrm{N}, 23^{\circ} \mathrm{W}-60^{\circ} \mathrm{E}\right)$ experienced its warmest year in the history of measurements with an anomaly of $+1.9^{\circ} \mathrm{C}$ (Fig. 7.36). Overall, the year was exceptionally warm and almost all of Europe reported temperatures higher than normal (Fig. 7.37). With the exception of Portugal, southern Spain, most of Italy, Ireland, and the northern United Kingdom, all of Europe observed anomalies well above $+1.0^{\circ} \mathrm{C}$. For many countries, the year proved to be the warmest or second warmest on record (warmest: Latvia, $+2.4^{\circ} \mathrm{C}$ above normal; Netherlands, $+1.6^{\circ} \mathrm{C}$; Belgium, $+1.9^{\circ} \mathrm{C}$; France and Switzerland, $+1.5^{\circ} \mathrm{C}$; Belarus, $+2.3^{\circ} \mathrm{C}$; European Russia, $+2.9^{\circ} \mathrm{C}$ [1961-90 base period]; Estonia, $+2.4^{\circ} \mathrm{C}$; Finland, $+2.4^{\circ} \mathrm{C}$; Lithuania, $+2.3^{\circ} \mathrm{C}$; Luxembourg, $+2.1^{\circ} \mathrm{C}$; Poland, $+1.9^{\circ} \mathrm{C}$; Kazakhstan, $+2.2^{\circ} \mathrm{C}$; Spain, $+1.2^{\circ} \mathrm{C}$; Sweden, $+2.0^{\circ} \mathrm{C}$; Norway, $+1.9^{\circ} \mathrm{C}$; Ukraine, $+2.8^{\circ} \mathrm{C}[1961-90]$; second warmest: Germany, $+1.6^{\circ} \mathrm{C}$; Denmark, $+1.5^{\circ} \mathrm{C}$; Romania, $+1.7^{\circ} \mathrm{C}$ ); third warmest: Turkey, $+1.4^{\circ} \mathrm{C}$ )

For central and southern European Russia, the eastern part of Ukraine, Turkey, Georgia in the South Caucasus, most of the Baltic states, and Greece, the year was characterized by a precipitation deficit. It was as low as $20 \%-60 \%$ of normal in wide regions around the Black Sea (Fig. 7.38). Germany, Switzerland, and most of France (except the most western parts) also received belownormal precipitation, as low as $60 \%-80 \%$ of normal across wide parts of Germany. Northern Europe, on the other hand, received above-normal precipitation, mostly around $125 \%$ of normal. Similarly, the eastern Iberian Peninsula, some regions of Italy, and many countries east of Germany reported above-normal precipitation.

Winter was very warm in all of Europe with anomalies from $+1^{\circ}$ to $+3^{\circ} \mathrm{C}$ on the Iberian Peninsula to $+5^{\circ} \mathrm{C}$ and above in the northeast of the region (Fig. 7.39). Only southern Greece, western Turkey, and the Middle East reported winter anomalies partly below $+1^{\circ} \mathrm{C}$. Between intense low pressure over Iceland and the northern North Atlantic and an Azores high extending to the 
western Mediterranean, a warm airflow from the North Atlantic prevailed. Anomalies within the high-pressure area were lower due to cold clear nights. In February, almost no areas in Europe observed anomalies below $+3^{\circ} \mathrm{C}$. Precipitation during winter (Fig. 7.40) was above normal for most countries north of the Alps due to frequent North Atlantic pressure systems, as well as for Turkey and the Middle East, where Mediterranean cyclones developed occasionally. These regions received precipitation mostly around $125 \%$ of normal but more than $167 \%$ of normal in localized areas. The western Iberian Peninsula, the Mediterranean, and the Balkan states received below-normal precipitation due to the influence of prevailing high-pressure systems.

Spring was warmer than usual in western Europe, where a high-pressure ridge dominated, with anomalies of $+1^{\circ}$ to $+3^{\circ} \mathrm{C}$, while central Europe had near-normal temperatures. The season started out warmer than usual in March for eastern and northern Europe with anomalies from $+1^{\circ} \mathrm{C}$ east of Germany to above $+5^{\circ} \mathrm{C}$ in European Russia. For western Europe, anomalies were below $+1^{\circ} \mathrm{C}$. During April, anomalies dropped below normal across eastern Europe, while in central and western Europe, anomalies ranged from just above normal in the southern and western Iberian Peninsula to $+5^{\circ} \mathrm{C}$ in central France under the influence of high pressure. During May, temperatures continued to be above normal for western Europe, the Mediterranean, and the Middle East, while temperatures for central, northern, and eastern Europe were below normal with anomalies of $-2^{\circ}$ to $-3^{\circ} \mathrm{C}$ for large parts of Poland, Belarus, and the Ukraine. Spring

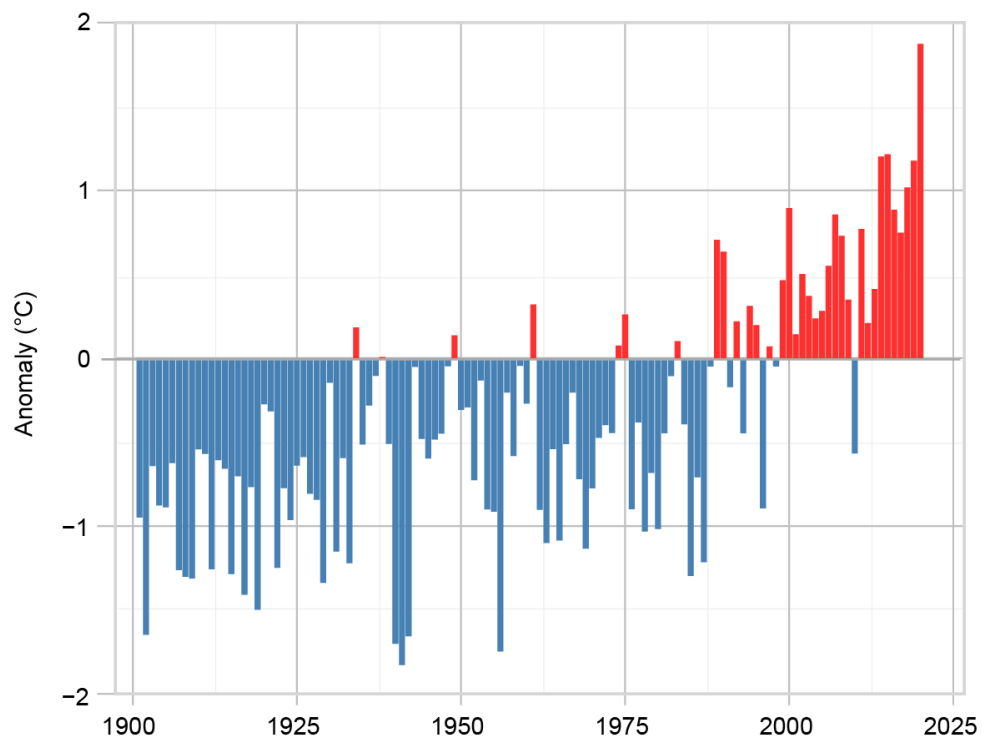

Fig. 7.36. Annual average land surface air temperature anomalies for $1900-2020$ for Europe $\left(36^{\circ}-72^{\circ} \mathrm{N}, 10^{\circ} \mathrm{W}-60^{\circ} \mathrm{E}\right)$ relative to the 1981-2010 base period. (Source: GHCN version 4.0.1 dataset [Menne et al. 2018].)



Fig. 7.37. Annual mean air temperature anomalies $\left({ }^{\circ} \mathrm{C} ; 1981-\right.$ 2010 base period) in 2020. (Source: interpolated climate station data, Deutscher Wetterdienst [DWD].

was wetter than normal for eastern Europe due to Arctic troughs extending into that area, with many areas receiving precipitation well above $167 \%$ of normal. Conversely, the Nordic and Baltic states, Germany, the BeNeLux countries (Belgium, Netherlands, and Luxembourg), Switzerland, many areas of France, the United Kingdom, as well as the central Mediterranean, were drier than normal, due to more high-pressure influence that contributed to a third successive spring precipitation deficit after 2018 and 2019. Northwestern Germany, the BeNeLux, and the southern United Kingdom received precipitation as low as $20 \%$ of normal. During this season, April was notably drier than normal in western, central, and eastern Europe (except for Russia), with widespread precipitation of $20 \%-60 \%$ of normal and some areas even below $20 \%$. 
The year continued with above-normal temperatures during summer. Anomalies for the season were around $+1^{\circ} \mathrm{C}$ for many countries. Lower-than-normal pressure in southwestern Europe and higher-than-normal pressure in the northeast led to an increased flow of subtropical warm air. Distribution of precipitation during the summer months was very inhomogeneous. South central Europe and the Balkan states, the United Kingdom, northwestern France, the northwestern parts of the Iberian Peninsula, and central Spain, which were in the low-pressure area, received above-normal precipitation. Northern Europe and the Baltic states, influenced by higherthan-normal pressure, as well as the southern parts of the Iberian Peninsula, which were strongly influenced by dry subtropical air from northern Africa, were drier than normal (20\%-60\% of normal) for the season. For many areas north of the Black Sea, precipitation was well below $60 \%$ of normal.



Fig. 7.38. European precipitation totals (\% of 1981-2010 average) for 2020. (Source: GPCC, created by DWD.)
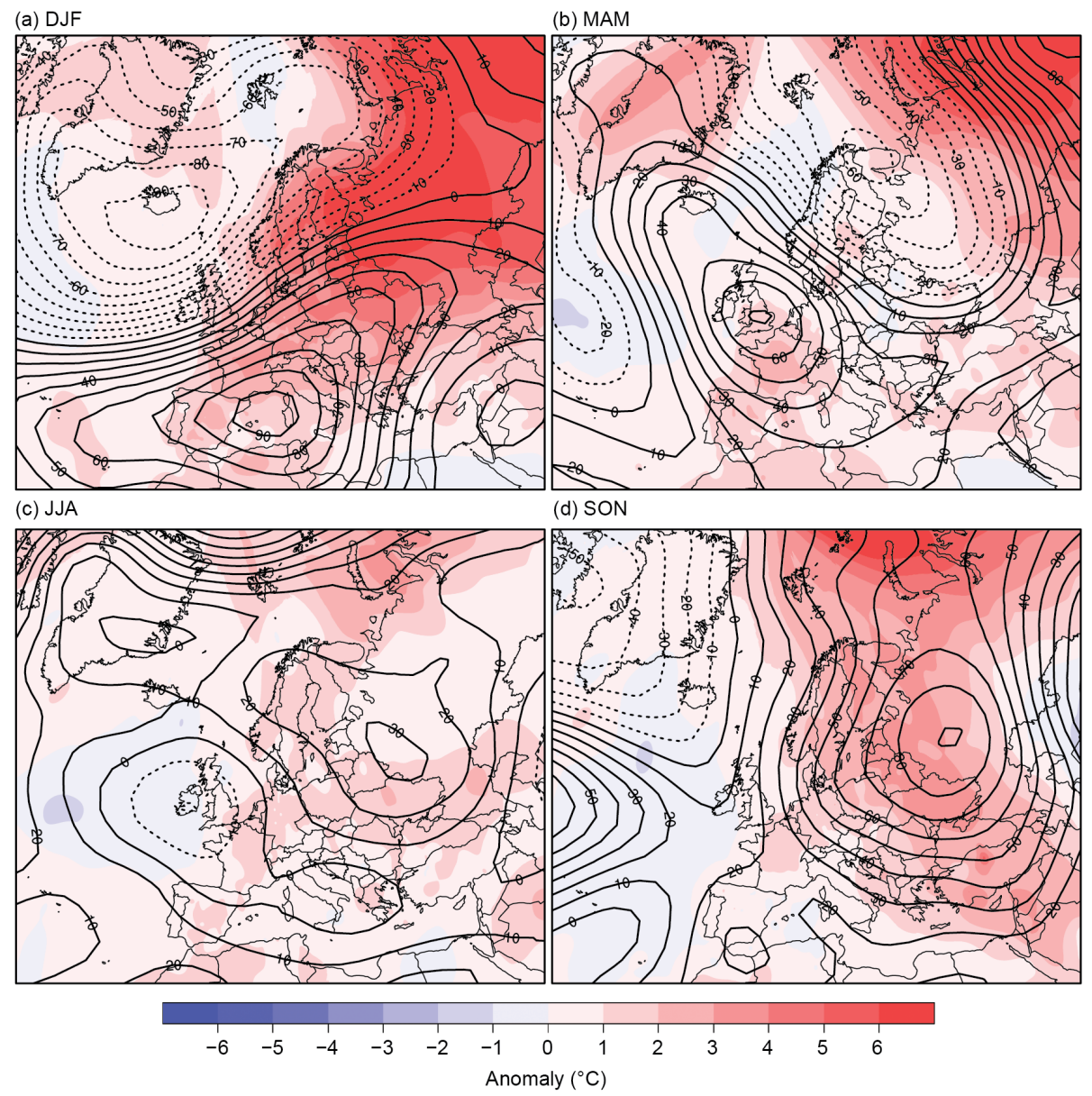

Fig. 7.39. Seasonal anomalies (1981-2010 base period) of 500-hPa geopotential height (contour; $\mathrm{m}$ ) and surface air temperature (shading; ${ }^{\circ} \mathrm{C}$ ) using data from the NCEP/NCAR reanalysis and DWD, respectively, for (a) DJF 2019/20, (b) MAM 2020, (c) JJA 2020, and (d) SON 2020. 

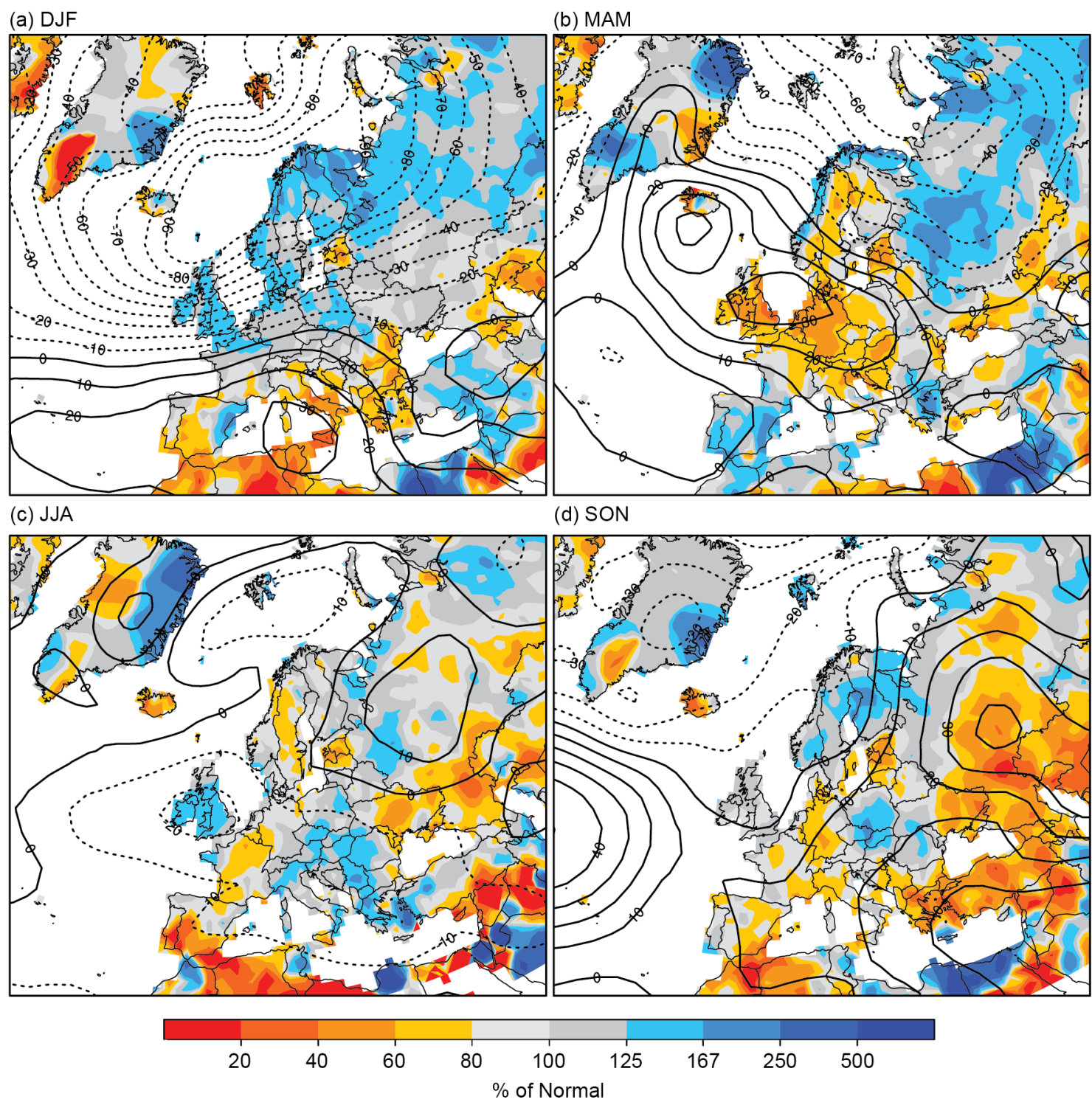

Fig. 7.40. Seasonal anomalies for 2020 (1981-2010 base period) of sea level pressure (hPa) from NCAR/NCEP reanalysis (contours) for (a) DJF 2019/20, (b) MAM 2020, (c) JJA 2020, and (d) SON 2020. Colored shading represents the percentage of seasonal mean precipitation for 2020 compared with the 1981-2010 mean from GPCC (Schneider et al. 2018).

Autumn was warmer than normal across Europe, except for areas on the Iberian Peninsula and Ireland. The Russian high was expanded to the west into Europe, and warm air from the Middle East reached much of the European continent. In most of western and central Europe, anomalies were between $+1^{\circ} \mathrm{C}$ and $+2^{\circ} \mathrm{C}$, while eastern Europe and the Baltic states observed anomalies of $+3^{\circ}$ to $+4^{\circ} \mathrm{C}$ due to higher warm air advection from the subtropics. Autumn precipitation was close to normal or slightly wetter than normal for Ireland, the United Kingdom, the BeNeLux, and the Scandinavian countries. In contrast, Germany, France, Switzerland, Italy, and the Iberian Peninsula received precipitation of around $80 \%$ of normal. Eastern Ukraine, southern European Russia, Turkey, and the South Caucasus, where high-pressure influence was strong, were even drier for the season, with precipitation mostly $40 \%-60 \%$ of normal.

December 2020 was again a warm month in Europe, except for Ireland in the west und parts of European Russia in the east. It was wetter than normal in December across much of western Europe, parts of northern Europe, and the central Mediterranean region, but very dry for the season in southern Iberia, parts of central Europe, much of eastern Europe, Turkey, and the Middle East. 


\section{2) Western Europe}

This region includes Ireland, the United Kingdom, Belgium, the Netherlands, Luxembourg, and France.

\section{(I) TEMPERATURE}

Except for the United Kingdom (third warmest with anomaly of $+0.8^{\circ} \mathrm{C}$ ) and Ireland (close to normal), all western European countries reported a record warm year (France: $+1.5^{\circ} \mathrm{C}$; Netherlands, $+1.6^{\circ} \mathrm{C}$; Belgium, $+1.9^{\circ} \mathrm{C}$; Luxembourg $+2.1^{\circ} \mathrm{C}$ ).

Winter was warmer than normal, and many countries reported average temperatures among their three warmest on record (anomalies: France, $+2.7^{\circ} \mathrm{C}$ [warmest]; Luxembourg, $+3.0^{\circ} \mathrm{C}$ [second warmest]; Netherlands, $+3.1^{\circ} \mathrm{C}$ [second warmest]; Belgium, $+2.7^{\circ} \mathrm{C}$ [second warmest]). Except for Ireland and the United Kingdom, every country reported anomalies of well above $+2.0^{\circ} \mathrm{C}$ for all three months. For February, anomalies between $+3.4^{\circ}$ and $+3.9^{\circ} \mathrm{C}$ were reported by France, the Netherlands, Belgium, and Luxembourg, making February 2020 one of the five warmest Februaries for each of these countries (second warmest for France).

Spring was very warm for France, Belgium, and Luxembourg (anomalies of $+1.7^{\circ} \mathrm{C},+1.2^{\circ} \mathrm{C}$, and $+2.0^{\circ} \mathrm{C}$, respectively), ranking second warmest for France and third warmest for Belgium and Luxembourg. Anomalies for Ireland, the United Kingdom, and the Netherlands were below $+0.9^{\circ} \mathrm{C}$. April was notably warm: France reported its third-warmest April with an anomaly of $+3.0^{\circ} \mathrm{C}$ as did Luxembourg $\left(+4.2^{\circ} \mathrm{C}\right)$. The United Kingdom and the Netherlands had their fifth$\left(+1.7^{\circ} \mathrm{C}\right)$ and sixth $\left(+1.9^{\circ} \mathrm{C}\right)$ warmest April on record, respectively. May was fifth warmest $\left(+1.5^{\circ} \mathrm{C}\right)$ for France, while Ireland, Belgium, and Luxembourg reported anomalies of around $+0.7^{\circ} \mathrm{C}$. The United Kingdom and the Netherlands temperatures were near normal.

Summer temperatures ranged from $+1.0^{\circ} \mathrm{C}$ above average in France to $+1.6^{\circ} \mathrm{C}$ in Luxembourg and was among the 10 warmest on record. Temperatures were only slightly above normal for the United Kingdom, and Ireland reported slightly below-normal temperatures. During July, both the United Kingdom and Ireland recorded temperature anomalies more than below $-1.0^{\circ} \mathrm{C}$ below average.

During autumn, temperatures again were very different on the isles from the mainland. While the United Kingdom and Ireland had temperatures near normal, Belgium, Luxembourg, and the Netherlands reported their fourth-warmest autumn (anomalies of $+1.4^{\circ} \mathrm{C},+1.7^{\circ} \mathrm{C},+1.2^{\circ} \mathrm{C}$, respectively) and France its fifth warmest $\left(+1 \cdot 1^{\circ} \mathrm{C}\right)$.

\section{(II) PRECIPITATION}

Precipitation for the year was close to normal in the region. Winter was wetter than normal for all countries, from 104\% of normal in Belgium to 143\% for the United Kingdom. Only southern France received slightly less-than-normal precipitation. The individual months of the season were wetter than normal except for January for the region and February for southern France, both of which were drier than normal. February was the wettest on record for the United Kingdom as well as for the Netherlands with $237 \%$ and $267 \%$ of normal, respectively, and second wettest for Luxembourg (237\% of normal).

Spring was drier than normal, with $40 \%-60 \%$ of normal precipitation for most of the region. The United Kingdom reported its fifth-driest May with only $47 \%$ of normal precipitation, contributing to one of its five driest springs on record.

Summer rainfall was between $66 \%$ and $85 \%$ of normal, except for the United Kingdom and Ireland, which received above-normal precipitation of around $135 \%$ of normal, and the Netherlands with near-normal precipitation. July was very dry for Belgium with 33\% of normal precipitation (fifth driest on record), Luxembourg 12\% of normal (second driest), and France 30\% of normal (record driest). 
During autumn, precipitation was near normal for Ireland, the United Kingdom, and Belgium, while Luxembourg, the Netherlands, and France reported slightly below-normal precipitation, between $84 \%$ and $90 \%$ of normal.

\section{(III) NOTABLE EVENTS AND IMPACTS}

During 19-20 January, western Europe experienced exceptionally high pressure. At Heathrow Airport (London) 1049.6 hPa was measured, which was the highest atmospheric sea level pressure recorded in the United Kingdom in more than 300 years. The same value was measured in Cherbourg (France), which broke the previous record set on 3 March 1990. The station Findel Airport (Luxembourg) and De Bilt (Netherlands) measured $1048 \mathrm{hPa}$. A consequence of the highpressure levels was record high sunshine duration in many places.

During February, two storms passing over northwestern Europe led to extensive traffic disruptions. Storm Ciara (9-11 February) reached strengths up to hurricane force (12 on the Beaufort Wind Scale); at exposed places in the United Kingdom and France, wind gusts surpassed $200 \mathrm{~km} \mathrm{~h}^{-1}$ and reached $120 \mathrm{~km} \mathrm{~h}^{-1}$ in lowland areas on 10 February. The central pressure of the low dipped below $940 \mathrm{hPa}$, and pressure differences between northern and southern Europe reached up to $80 \mathrm{hPa}$. Daily precipitation in some areas reached almost $75 \%$ of the monthly normal (e.g., $180 \mathrm{~mm}$ at Lake District, northern England), leading to record high river levels and flooding. In the United Kingdom, the Netherlands, Belgium, and France, public transport experienced major disruptions due to delays and cancellations of train, flight, and ferry connections. While the extremely low air pressure in northern Europe was a risk to flying, mainly due to increased turbulence, some non-cancelled flights even profited from this special situation resulting in a new record for crossing the Atlantic in under five hours set by a British Airways aircraft due to higher wind speeds. Since soils were already saturated by rainfall brought by Storm Ciara, the heavy rain brought by the second storm, Dennis (15-16 February), caused record river levels and widespread flooding in the United Kingdom and Ireland. In south Wales at the Crai Reservoir in Powys, $157.6 \mathrm{~mm}$ of precipitation was measured in 48 hours, which is more than the normal total for February.

The high-pressure influence from the Azores and continued southwesterly winds resulted in unusually warm temperatures in February across Europe. In southern France, record temperatures for February were set. Never before it has been so warm so early in the year and new records were set at multiple stations; for example, Biarritz reported $26.6^{\circ} \mathrm{C}$, which is higher than the monthly mean for July and August, and Cambo-les-Bains reached $27.8^{\circ} \mathrm{C}$. In Bastia on Corsica, the temperature did not drop below $21.9^{\circ} \mathrm{C}$ on $10-11$ February, making it the first tropical night (minimum temperature $>20^{\circ} \mathrm{C}$ ) ever during the winter season at this location.

During a heat wave from 6 to 13 August, exceptionally high temperatures were measured. Much of England experienced temperatures above $30^{\circ} \mathrm{C}$ on the 7 th and 9 th. Heathrow and Kew Garden reported a maximum of $36.4^{\circ} \mathrm{C}$. The Netherlands counted a record of eight consecutive tropical days with daily maximum temperatures above $30^{\circ} \mathrm{C}$. At station De Bilt (the Netherlands), a new weekly average maximum temperature record of $33.2^{\circ} \mathrm{C}$ was set. Large parts of France experienced temperatures around $30^{\circ} \mathrm{C}$.

On 3 October, southeastern France experienced extreme precipitation. Mons (west of Nice) reported $571 \mathrm{~mm}$ in 24 hours; in Saint-Martin-Vésubie (same region), a new daily record was set with a 24-hour total of $500 \mathrm{~mm}$. On the same day, due to storm Alex which remained quasi-stationary that day, many weather stations in southern central England and eastern Scotland reported their wettest October day on record. The United Kingdom area average for this day was $31.7 \mathrm{~mm}$, which made it the wettest day on record (series starting in 1891). 


\section{3) Central Europe}

This region includes Germany, Switzerland, Austria, Poland, Czechia, Slovakia, and Hungary.

\section{(I) TEMPERATURE}

Annual temperatures ranged from $+1.0^{\circ}$ to $+1.9^{\circ} \mathrm{C}$ above normal in central Europe. Switzerland and Poland reported their warmest year on record (anomalies of $+1.5^{\circ} \mathrm{C}$ and $+1.9^{\circ} \mathrm{C}$, respectively) and Germany reported its second $\left(+1.6^{\circ} \mathrm{C}\right)$. The winter season was especially warm. It was the warmest winter on record for Switzerland and Poland with anomalies of $+2.9^{\circ}$ and $+4.1^{\circ} \mathrm{C}$, respectively, and second warmest for Germany $\left(+3.3^{\circ} \mathrm{C}\right)$, Austria $\left(+2.7^{\circ} \mathrm{C}\right)$, and Czechia $\left(+3.3^{\circ} \mathrm{C}\right)$. Hungary and Slovakia each observed one of their five warmest winters, with anomalies of $+2.6^{\circ}$ and $+2.8^{\circ} \mathrm{C}$. All winter months were warmer than usual, but February temperatures were near-record high. It was the second-warmest February for Germany $\left(+4.4^{\circ} \mathrm{C}\right)$, Switzerland $\left(+3.9^{\circ} \mathrm{C}\right)$, Austria $\left(+4.1^{\circ} \mathrm{C}\right)$, Poland $\left(+4.7^{\circ} \mathrm{C}\right)$, and Czechia $\left(+4.7^{\circ} \mathrm{C}\right)$.

During spring, temperature anomalies were below $+1.0^{\circ} \mathrm{C}$, except for Switzerland, which reported $+1.8^{\circ} \mathrm{C}$ above normal, its third-warmest spring. Germany and Austria reported spring anomalies of $+0.6^{\circ}$ and $+0.8^{\circ} \mathrm{C}$, while Poland, Czechia, Slovakia, and Hungary observed nearnormal temperatures.

Summer was about $+1.0^{\circ} \mathrm{C}$ above normal for the region. In June, anomalies for Germany and Poland were above $+1.0^{\circ} \mathrm{C}$, while the rest of the region was cooler than normal. Except for Switzerland (anomaly $+1.2^{\circ} \mathrm{C}$ ), temperatures were near normal in July. The season ended with a warmer-than-normal August: anomalies were above $+1.0^{\circ} \mathrm{C}$ for all countries in the region. Poland, Hungary, and Germany observed anomalies of $+2.0^{\circ} \mathrm{C}$ and above, with Germany reporting its second-warmest August.

For autumn, temperatures were mostly $+1.0^{\circ}$ to $+1.4^{\circ} \mathrm{C}$ above normal, except for Poland $\left(+2.0^{\circ} \mathrm{C}\right)$ and Austria $\left(+0.7^{\circ} \mathrm{C}\right)$. In September, anomalies were well above $+1.0^{\circ} \mathrm{C}$ for the whole region, but in October, Austria reported normal temperatures and Switzerland was slightly colder than normal. On the other hand, Switzerland reported its fourth-warmest November, with an anomaly of $+2.5^{\circ} \mathrm{C}$. Germany reported an anomaly of $+1.8^{\circ} \mathrm{C}$, while Poland was $+2.5^{\circ} \mathrm{C}$ above average, making this one of its five warmest Novembers on record.

\section{(II) PRECIPITATION}

Precipitation was close to normal (86\%-116\%) in the region for the year. Winter was slightly wetter than normal, with $100 \%-120 \%$ of normal precipitation. In January, only Poland received above-normal precipitation even though rain mostly fell in the north. All other countries reported $40 \%-60 \%$ of normal precipitation. Winter ended with a considerably wetter-than-normal February, with most of the countries receiving well above $160 \%$ of their normal precipitation. Germany reported $228 \%$ of its normal precipitation, its second-wettest February. Only Hungary observed near-normal precipitation.

In spring, only some local areas received above $80 \%$ of normal precipitation. Germany and Hungary reported countrywide precipitation slightly below $60 \%$ of normal. Except for Hungary and Slovakia, which received close-to-normal precipitation, the season started drier than normal for the region. April was notably dry. Countrywide precipitation did not exceed $60 \%$ of normal anywhere and was even below $40 \%$ of normal for multiple countries. Germany reported 33\% of its normal precipitation, Poland 23\%, Hungary 25\%, Slovakia 20\%, and Czechia 39\%. While May continued to be drier than normal for Switzerland, Hungary, and especially Germany, which reported $54 \%$ of normal precipitation, Poland, Czechia, and Austria reported slightly above-normal precipitation. Overall, this was the third-driest spring (following 2018 and 2019) for much of central Europe. However, this did not continue into summer.

During the summer season, Germany and Switzerland received near-normal precipitation. For the other countries in the region, precipitation ranged from around $110 \%$ of normal in Poland 
to around $140 \%$ of normal in Austria, Hungary, and Czechia. With the exception of July, when countrywide precipitation was below normal for Switzerland, Germany, Czechia, and Poland, precipitation was above normal in central Europe during all of summer.

Autumn was drier than normal for Switzerland and Germany, with $76 \%$ of normal precipitation while the rest of the region received above-normal precipitation. For Germany, Switzerland, and Hungary, the season started with a drier-than-normal September $(60 \%-80 \%$ of normal precipitation). Poland, Slovakia, Czechia, and Austria received above-normal precipitation, up to $150 \%$ of normal. October was wetter than normal for all countries in the region; precipitation ranged from $124 \%$ of normal in Germany to above $200 \%$ for Hungary and Czechia. Parts of Slovakia reported precipitation close to $300 \%$ of normal. The season ended with a very dry November; precipitation did not exceed $60 \%$ of normal across the region. Germany, Austria, Switzerland, and Hungary reported only around $30 \%$ of their normal precipitation.

\section{(III) NOTABLE EVENTS AND IMPACTS}

Between 9 and 11 February, Storm Sabine (Storm Ciara in Western Europe, as noted earlier) caused wind speeds up to hurricane force (12 on the Beaufort Wind Scale) in central Europe. At the station Feldberg in Germany, gusts up to $177 \mathrm{~km} \mathrm{~h}^{-1}$ were measured on 10 February. In Andermatt (Switzerland) and Sniezka (Poland), gusts of $202 \mathrm{~km} \mathrm{~h}^{-1}$ and $198 \mathrm{~km} \mathrm{~h}^{-1}$ were measured, respectively. In Germany, daily precipitation totals around $40 \mathrm{~mm}$ were reported, which led to local flooding, for example at the fish market in Hamburg. Additionally, a record amount of wind power-equivalent to 44 nuclear power plants-was produced. The ongoing warm airflow from the southwest caused record high temperatures. On 3 February new daily minimum temperature records of $10.6^{\circ} \mathrm{C}$ at the University of Pécs (Hungary), $9.2^{\circ} \mathrm{C}$ in Budapest, and $12.5^{\circ} \mathrm{C}$ in Payerne (Switzerland) were set. A new daily maximum record for February $\left(23.9^{\circ} \mathrm{C}\right)$ was observed the same day in Magadino/Cadenazzo (southern Switzerland). On 16 February, a new daily high-temperature record of $18.2^{\circ} \mathrm{C}$ was set in Czechia. Germany reported a new monthly record of $19.4^{\circ} \mathrm{C}$ at the station in Worms. The exceptional warmth even reached high up into the Alps, leading to new February maximum temperature records at several mountain stations; for example, a temperature of $3.9^{\circ} \mathrm{C}$ was measured at the station Sonnblick Mountain in Austria (3106-m a.s.1.), the highest since 1886.

During 12-19 June, as a result of an almost stationary low-pressure system, central Europe experienced thunderstorms accompanied by sometimes heavy precipitation. Some areas in Germany received daily precipitation amounts of more than $60 \mathrm{~mm}$. Locally, in combination with hail, 1-hour totals of 20 to $40 \mathrm{~mm}$ were measured. The highest daily sum of $133 \mathrm{~mm}$ occurred at station Bottmersdorf (southwest of Magdeburg). In Slovakia, a 1-day precipitation total of $129.1 \mathrm{~mm}$ was recorded on 19 June at the border of the central and eastern part of Slovakia at Muráň, causing flooding in this area.

During 26-29 June, Poland, Hungary, and Slovakia received exceptional amounts of localized precipitation during thunderstorms that caused flooding. Several areas in Poland received above $50 \mathrm{~mm}$ of rain in 24 hours. At the station Jaslo (Podkarpackie, foreland of Carpathian Mountains), $100 \mathrm{~mm}$ fell in 5 hours, and 1-hour totals of 30 to $40 \mathrm{~mm}$ were recorded. Wind with gusts up to $90 \mathrm{~km} \mathrm{~h}^{-1}$ and hail up to $4 \mathrm{~cm}$ in diameter were reported in Szczecinek (Middle Pomerania, western Poland). River water levels rose by more than $3 \mathrm{~m}$ in 1 day. The provinces Masovia (including Warsaw), Lesser Poland, and Podkarpackie were most affected. On 28 June at the station Muránská Huta-Predná Hora in eastern central Slovakia, $102 \mathrm{~mm}$ of rain fell in 1 hour and a 24-hour total of $132 \mathrm{~mm}$ was measured, raising the nearby Zdychava River water level by $0.75 \mathrm{~m}$ in 1 hour and 15 minutes. In Hungary, 24-hour totals up to $95 \mathrm{~mm}$ were reported, of which most was received within half an hour. 


\section{4) The Nordic and Baltic countries}

This section includes Iceland, Norway, Denmark, Sweden, Finland, Estonia, Latvia, and Lithuania.

\section{(I) TEMPERATURE}

It was a record warm year for many of the Nordic and the Baltic countries: Latvia (anomaly of $\left.+2.4^{\circ} \mathrm{C}\right)$, Lithuania $\left(+2.5^{\circ} \mathrm{C}\right)$, Norway $\left(+1.9^{\circ} \mathrm{C}\right)$, Estonia $\left(+2.9^{\circ} \mathrm{C}\right)$, and Sweden $\left(+2.0^{\circ} \mathrm{C}\right)$. Denmark observed its second-warmest year, at $+1.5^{\circ} \mathrm{C}$. In Iceland, temperatures were near normal.

Winter was exceptionally warm, with anomalies well above $+4.0^{\circ} \mathrm{C}$ across the region and close to $+6.0^{\circ} \mathrm{C}$ for most of the Baltic countries. Norway, Finland, Denmark, Estonia, Latvia, and Lithuania all reported their warmest winter on record. While all winter months were warmer than normal and often ranked among their five warmest in the various countries, January was particularly notable as it was the warmest on record for all countries of the Nordic and Baltic regions with widespread anomalies of around $+5.0^{\circ} \mathrm{C}$ and above.

Spring was slightly warmer than normal as anomalies were up to $+0.6^{\circ} \mathrm{C}$. March was warmer than usual and temperatures ranged from around $+2.0^{\circ} \mathrm{C}$ above normal in Norway to around $+3.0^{\circ} \mathrm{C}$ above normal in the Baltic countries. In April, only Denmark, southern Sweden, and southern Norway reported above-normal temperatures, while Finland, Estonia, Latvia, and Lithuania were near to slightly colder than normal. The season ended with below-normal temperatures in May across the entire region (except Iceland), close to $-2.0^{\circ} \mathrm{C}$ below normal in the Baltic countries.

Summer again was slightly warmer than normal, with anomalies of $+0.7^{\circ}$ to $+1.3^{\circ} \mathrm{C}$. Temperatures in Iceland were near normal. June was the warmest month of the season; many countries reported anomalies close to or above $+3.0^{\circ} \mathrm{C}$. Only Iceland reported a lower, but still positive, anomaly of $+0.9^{\circ} \mathrm{C}$. July was colder than normal everywhere, with anomalies from $-1.0^{\circ}$ to $-1.7^{\circ} \mathrm{C}$ (Iceland $-0.7^{\circ} \mathrm{C}$ ). During August, temperatures were once again above normal, but only Denmark and Sweden reported monthly anomalies above $+1.0^{\circ} \mathrm{C}$.

Autumn was exceptionally warm and the warmest on record for Lithuania, Latvia, Estonia, and Finland with anomalies of around $+3.0^{\circ} \mathrm{C}$. In Denmark, Norway, and Sweden, anomalies were $+1.5^{\circ}$ to $+2.3^{\circ} \mathrm{C}$, making this the fourth-warmest autumn for these countries. October and November were record warm for some countries. Lithuania reported its warmest October $\left(+3.0^{\circ} \mathrm{C}\right.$ above normal) as did Latvia $\left(+3.2^{\circ} \mathrm{C}\right)$. November was the warmest for Estonia (anomaly of $+4.0^{\circ} \mathrm{C}$ ), Finland $\left(+4.5^{\circ} \mathrm{C}\right)$, and Latvia $\left(+4.0^{\circ} \mathrm{C}\right)$, second warmest for Denmark $\left(+2.6^{\circ} \mathrm{C}\right)$, and third warmest for Lithuania $\left(+3.5^{\circ} \mathrm{C}\right)$. For Iceland, with the exception of October with a slightly above average anomaly of $+1.0^{\circ} \mathrm{C}$, temperatures were near normal.

\section{(II) PRECIPITATION}

For most countries of the region, precipitation was near normal for the year. Norway reported above-normal precipitation (120\% of normal), making 2020 its second-wettest year on record. Denmark reported 104\% of its normal precipitation. Latvia and Estonia received only around $60 \%$ of normal precipitation, with lesser amounts in some areas.

Winter was wetter than normal with precipitation ranging from $108 \%$ of normal in Latvia to $155 \%$ of normal in Norway. For Norway, this was its wettest winter on record and second wettest for Denmark (155\%). Except for January in Latvia and Estonia, all months of the season were wetter than normal in the region. In February, Denmark received a record high precipitation total of $284 \%$ of normal, making this its wettest February on record.

Spring was drier than normal for Sweden, Denmark, Latvia, and Estonia with precipitation between $66 \%$ and $80 \%$ of normal. Finland, Iceland, and Lithuania reported near-normal precipitation. Only Norway saw a wetter-than-average spring, with $130 \%$ of normal precipitation. During March, most countries reported near- to slightly-above-normal precipitation. Only Denmark was 
dry, reporting $71 \%$ of normal precipitation. April was also drier than normal for Denmark (63\% of normal), along with Latvia (53\% of normal) and Lithuania (26\%). Norway and Estonia, however, received $130 \%$ and around $116 \%$ of their normal precipitation, respectively. With the exception of Latvia, Lithuania, and Norway, where precipitation was close to normal, the end of the spring was drier than normal, with countrywide precipitation reported between $50 \%$ and $80 \%$ of normal.

During summer, overall precipitation was near to slightly above normal for all countries of the region, except for Estonia, where the dry spring evolved into a summer drought. June was drier than normal in Sweden, northern Norway, and Estonia, with many areas receiving only 40\%-80\% of normal precipitation. Other countries reported around $120 \%$ of their normal precipitation. In July, many areas received around $120 \%$ of normal precipitation; however, Estonia received only $80 \%$ of its normal precipitation. The season ended dry across the region. While Denmark and Lithuania reported around $90 \%$ of normal precipitation in August, other countries reported only $60 \%-80 \%$.

For autumn, Denmark and the Baltic states reported $80 \%-90 \%$ of normal precipitation while Scandinavian countries received precipitation around 120\% of normal. September was drier than normal, with around 50\% of normal precipitation in Denmark and Lithuania and around 80\% of normal precipitation for Latvia and Estonia. Norway and Finland each reported above-normal precipitation around $120 \%$ of normal. In October, Sweden received close to $200 \%$ of its normal precipitation. While the national average in Finland was around 125\% of normal, some northern areas received more than $160 \%$ of normal precipitation. For the other countries in the region, October was close to normal. Only Iceland reported below-normal precipitation, around 75\% of normal. The season ended with a wetter-than-normal November across the Scandinavian countries with around $120 \%$ of normal precipitation. Lithuania, Latvia, Estonia, and Iceland received $80 \%-90 \%$ of normal precipitation during the month. Denmark reported only $68 \%$ of its normal.

\section{(III) NOTABLE EVENTS AND IMPACTS}

In January, strong westerlies brought warm and dry air to Scandinavia that caused record high temperatures. On 2 January, the station Sunndalsøra in western central Norway (located near the western coast) measured $19.0^{\circ} \mathrm{C}$, which was the highest temperature ever recorded during winter in Scandinavia. Many other stations in Norway recorded temperatures of $15^{\circ}-18^{\circ} \mathrm{C}$. New records were also set in Sweden. At station Oskarshamn (Småland, located at the Baltic Sea coast of Sweden), $12.1^{\circ} \mathrm{C}$ was reported, which tied the previous January record set in 2007. South of Norrland (mainly central Sweden), January temperatures were the highest for the last 50 years. On 8 January, a new record of $10.5^{\circ} \mathrm{C}$ was set at station Orebro (southern Sweden) where measurements started in 1858. Temperatures remained high and further records were set on 20 and 21 January when daily maximum temperatures exceeded $10.0^{\circ} \mathrm{C}$ at many stations in Norway and Sweden.

On 14 April, record-breaking snowfall was measured in northern and central Finland. The station Tahtela at Sodankylä reported $1.25 \mathrm{~m}$ of new snow, breaking the old record of $1.19 \mathrm{~m}$ from 6 April 2000. Additional extreme snowfall was observed in Norway, where daily snow accumulation of up to 1.2 m occurred locally around Tromsö. During 4-5 April, a blizzard with wind gusts up to $111 \mathrm{~km} \mathrm{~h}^{-1}$ brought up to $1.5 \mathrm{~m}$ of snow in 24 hours in Iceland. Roads were closed and flights cancelled.

During May, several towns were threatened by flooding due to melting of the exceptional amount of snow accumulated during winter in northern Sweden and Finland (Lapland received the most in the last 60 years). On 31 May, the station Kittilä's Poka (Finnish Lapland) still measured $45 \mathrm{~cm}$ of snow, which is a new record for the 49-year-long series.

From 14 to 27 June, Scandinavia experienced a heat wave with high temperatures exceeding $30^{\circ} \mathrm{C}$ in many places. In Norway, a record high number of 11 days with daily maximum temperature surpassing $30^{\circ} \mathrm{C}$ occurred in June in several locations. New records were set at 36 stations in Norway. The highest temperature of $34.3^{\circ} \mathrm{C}$ was reached in Trondheim on 27 June. In Sweden, 
the highest June temperature in Sweden since 1970 (34.0 ${ }^{\circ}$ ), was measured at Skelleftea Airport (Västerbotten Province, at the northern Baltic Sea coast) on 25 June.

During November many new temperature records were set in Scandinavia as warm air flowed north on the east side of ex-hurricane Zeta at the beginning of the month. In Norway, three new county records were recorded on 6 November: In Oslo, Blindern measured $16.1^{\circ} \mathrm{C}$; in Viken, Råde-Tomb recorded $17.6^{\circ} \mathrm{C}$; and in Vestfold and Telemark, Melsom recorded $17.4^{\circ} \mathrm{C}$. On 18 November, a temperature of $15.1^{\circ} \mathrm{C}$ was measured at the Swedish stations Norrköping and Oskarshamn. This was the highest temperature ever observed in Sweden so late in the course of a year.

\section{5) Iberian Peninsula}

This region includes Spain, Portugal (1971-2000 base period), and Andorra.

\section{(I) TEMPERATURE}

The Iberian Peninsula observed its warmest year on record. Spain and Portugal reported temperature anomalies of $+1.1^{\circ}$ and $+1.0^{\circ} \mathrm{C}$, respectively.

Winter was warmer than usual. Spain and Portugal each reported their second-warmest winter with anomalies of $+1.8^{\circ}$ and $+1.5^{\circ} \mathrm{C}$. During February, when the Iberian Peninsula was under extensive high pressure, temperatures were higher than normal and resulted in a record warm month for Spain (tied with 1990) with an anomaly of $+3.0^{\circ} \mathrm{C}$ and $+2.5^{\circ} \mathrm{C}$ for Portugal.

Spring anomalies were $+1.5^{\circ} \mathrm{C}$ for Spain (fourth warmest) as well as for Portugal. Blocking high pressure over the British Islands (Fig. 7.39b) led to exceptionally above-normal temperatures and made May the warmest on record for both Spain $\left(+2.7^{\circ} \mathrm{C}\right.$ above normal $)$ and Portugal $\left(+3.3^{\circ} \mathrm{C}\right)$.

Summer started with a near-normal June, but was followed by the warmest July on record for Portugal (anomaly $\left.+4.6^{\circ} \mathrm{C}\right)$ and third warmest for Spain $\left(+2.0^{\circ} \mathrm{C}\right)$. August concluded the season with near-normal temperatures for Portugal and slightly above-normal temperatures for Spain.

Autumn temperatures were slightly above normal, but with variations between months. While October was colder than normal with anomalies just above $-1.0^{\circ} \mathrm{C}$, the season ended with a very warm November, the third warmest for Spain $\left(+2.0^{\circ} \mathrm{C}\right.$ above normal).

\section{(II) PRECIPITATION}

The Iberian Peninsula received near-normal precipitation during the year, at least on areal average. During winter, precipitation was near-normal for Spain on average, but distributed inhomogeneously; eastern Spain received above-normal precipitation while the rest of the country received below-normal precipitation. Portugal reported slightly below-normal precipitation. February was extremely dry; most of Spain received less than $25 \%$ of its normal precipitation and Portugal received less than $40 \%$ of its normal.

In spring, above-normal precipitation for both March and April (both well above 125\% of normal) was followed by a drier-than-normal May. Overall, spring was wetter than normal, with $137 \%$ and $114 \%$ of normal precipitation for Spain and Portugal, respectively.

Summer precipitation was close to normal for much of Spain, while Portugal reported only 45\% of normal and its spatial distribution was very inhomogeneous. During autumn, an opposite pattern emerged, and Portugal received near-normal precipitation while Spain observed only 86\% of its normal. September was drier than normal almost everywhere on the Iberian Peninsula except for the center of Spain. During October, southern Spain was very dry with precipitation as low as 25\% of normal, while northern Spain and Portugal received above-normal precipitation. The season ended wetter than normal in November for southern Portugal as well as eastern Spain; northern Spain received less than $60 \%$ of its normal precipitation. 
(III) NOTABLE EVENTS AND IMPACTS

On 18-25 January, Storm Gloria impacted Spain, bringing abundant precipitation to the Mediterranean coast and the Balearic Islands, with more than $100 \mathrm{~mm}$ totals over an extensive coastal strip between Catalonia and Alicante and surpassing $400 \mathrm{~mm}$ at many stations within this strip.

Between 31 March and 1 April, the coastal region of Valencia in eastern Spain was hit by torrential rainfall, which led to flash floods. Between $34 \mathrm{~mm}$ and $39 \mathrm{~mm}$ of rainfall was measured, which is about four times the normal for these two days. Locally, station Castellon recorded $150 \mathrm{~mm}$ of daily precipitation, which was its highest total since 1976. The municipality of La Pobla Tornesa registered $197.6 \mathrm{~mm}$ of rain in 24 hours.

From 19 to 31 May, a heat wave affected Portugal and western Spain. Highest daily temperatures exceeded $37^{\circ} \mathrm{C}$, for example, $37.3^{\circ} \mathrm{C}$ in Pinháo (Portugal) on 28 May.

During the summer of 2020, there were several significant warm episodes, with two heat waves observed in mainland Spain and the Balearic Islands in July and August. A major heat wave occurred from 25 July to 2 August, with temperatures exceeding $40^{\circ} \mathrm{C}$ across much of the southwest quadrant of the Iberian Peninsula and in parts of the southeast, the interior of Ebro Valley, eastern Cantabrian, and the island of Mallorca.

During 4-5 November, a low-pressure system led to heavy rain and thunderstorms. The region around Valencia recorded 48-hour totals of up to $500 \mathrm{~mm}$ (e.g., $502 \mathrm{~mm}$ in Sueca/Muntanyeta dels Sants). In Ardales, a 24-hour total of $148 \mathrm{~mm}$ was recorded, which is almost 50\% higher than the November monthly average of $100 \mathrm{~mm}$. Roads were closed as a consequence of flash floods and landslides. Damaged tracks on the route Algeciras-Madrid led to a derailed train in Teba.

\section{6) Central Mediterranean region}

This region includes Italy (1961-90 base period), Monaco, Malta, Slovenia, Croatia, Serbia, Montenegro, Bosnia and Herzegovina, Albania, Macedonia, Greece, and Bulgaria.

\section{(I) TEMPERATURE}

The year was warmer than normal for the central Mediterranean, with anomalies between $+0.9^{\circ} \mathrm{C}$ and $+1.9^{\circ} \mathrm{C}$. Italy reported its third-warmest year on record $\left(+1.6^{\circ} \mathrm{C}\right.$ above normal $)$ and Slovenia its fifth warmest $\left(+1.3^{\circ} \mathrm{C}\right)$.

During winter, anomalies ranged from around $+1.0^{\circ} \mathrm{C}$ in Greece to above $+3.0^{\circ} \mathrm{C}$ in Slovenia. It was the second-warmest winter for Italy $\left(+2.3^{\circ} \mathrm{C}\right.$ above normal) and third warmest for Slovenia $\left(+3.1^{\circ} \mathrm{C}\right)$. During January, only Italy, Slovenia, and Bulgaria reported temperatures more than $+1.0^{\circ} \mathrm{C}$ above normal. Temperatures were close to normal in Greece while the rest of the region reported anomalies between $+0.4^{\circ}$ and $+0.9^{\circ} \mathrm{C}$. February was exceptionally warm for Greece; in Malta anomalies were less than $+2.0^{\circ} \mathrm{C}$. The highest nationwide anomaly for the region was reported by Slovenia $\left(+4.5^{\circ} \mathrm{C}\right.$ above normal), its second-warmest February on record. Anomalies well above $+3.0^{\circ} \mathrm{C}$ were reported by Bosnia and Herzegovina, Bulgaria, Croatia, and Serbia.

Spring was slightly warmer than normal for most of the region, with temperatures mostly ranging from $+0.2^{\circ} \mathrm{C}$ above normal in North Macedonia to $+0.8^{\circ} \mathrm{C}$ above normal in Slovenia; only Italy and Albania reported higher anomalies of $+1.5^{\circ} \mathrm{C}$. March temperatures ranged from $+1.0^{\circ} \mathrm{C}$ above normal in Italy and Slovenia to $+1.3^{\circ} \mathrm{C}$ for most of the Balkans; however, in Bulgaria, anomalies were above $+2.0^{\circ} \mathrm{C}$. During April, Italy, Slovenia, and Croatia all reported $+1.5^{\circ} \mathrm{C}$ anomalies, while temperatures were near normal in Greece, North Macedonia, and Bulgaria. The season ended near to slightly colder than normal (anomalies up to $-0.5^{\circ} \mathrm{C}$ ) for most of the region in May, with the exception of Italy and Greece, which had positive anomalies of $+1.9^{\circ}$ and $+1.0^{\circ} \mathrm{C}$.

During summer, temperatures were around $+0.5^{\circ} \mathrm{C}$ above normal for most of the region. Only Italy, Albania, and Greece reported temperatures above $+1.0^{\circ} \mathrm{C}$ of normal. Summer started with near- to slightly below-normal temperatures for the whole region during June. July was near 
normal in the north of the Balkans and warmer than normal in the south; Greece and Albania reported anomalies between $+1.0^{\circ}$ and $+2.0^{\circ} \mathrm{C}$. With temperatures $+1.0^{\circ}$ to $+1.5^{\circ} \mathrm{C}$ above normal, the season ended with a warmer-than-normal August for the whole region.

Autumn temperatures were $+1.0^{\circ}$ to $+2.0^{\circ} \mathrm{C}$ above normal for the Balkan Peninsula, while most of Italy and Slovenia reported anomalies below $+1.0^{\circ} \mathrm{C}$. September was the warmest month of the season. Italy and Slovenia reported anomalies of $+1.7^{\circ}$ and $+1.4^{\circ} \mathrm{C}$, respectively, and on the Balkan Peninsula, temperatures were between $+2.0^{\circ} \mathrm{C}$ and $+3.0^{\circ} \mathrm{C}$ above normal. For Italy and Malta, October was colder than normal by $-0.7^{\circ} \mathrm{C}$. Slovenia and Croatia reported near-normal temperatures. In Serbia, Bosnia and Herzegovina, and Greece, anomalies were $+1.0^{\circ}$ to $+1.5^{\circ} \mathrm{C}$. Temperature anomalies exceeded $+2.0^{\circ} \mathrm{C}$ in Bulgaria. The season ended with anomalies around $+2.0^{\circ} \mathrm{C}$ for Italy, Albania, and Montenegro in November. In Slovenia, Croatia, Bosnia and Herzegovina, Bulgaria, Greece, and Malta, anomalies did not exceed $+0.6^{\circ} \mathrm{C}$.

\section{(II) PRECIPITATION}

Overall, annual precipitation in the region was $80 \%$ to slightly above $100 \%$ of normal. Seasonally, winter was drier than normal in central and southern Italy, Malta, North Macedonia, most of Greece, and some parts of Bulgaria, Croatia, and Bosnia and Herzegovina with mostly $60 \%-80 \%$ of normal precipitation. In Sicily (Italy) and Malta, precipitation was only around 30\% of normal. January was drier than normal for the whole region; with some local exceptions, precipitation did not exceed $60 \%$ of normal. For central and southern Italy, Malta, most of Greece, and some parts of Bulgaria and Croatia, rainfall was below $20 \%$ of normal. The season ended wetter than normal for Bulgaria and Serbia, while drought conditions, severe in some places, prevailed in most of Italy and Greece, where precipitation was just $20 \%$ and $40 \%$ of normal in February. Sicily and Malta received less than $20 \%$ of their normal precipitation. Overall, February was the driest on record for Malta and second driest for Italy.

Spring was wetter than normal for Bulgaria, Greece, North Macedonia, and Albania, with some areas receiving around $160 \%$ of their normal precipitation. Slovenia, Croatia, Bosnia and Herzegovina, and Italy, in contrast, reported precipitation around $80 \%$ of normal. In March, only Croatia and Bosnia and Herzegovina received below-normal precipitation (60\%-80\%), while the rest of the region had near- to slightly above-normal precipitation. April was drier across the region (20\%-60\% of normal), except for Greece, North Macedonia, and southern Bulgaria, where some areas received more than $170 \%$ of normal precipitation. May was drier than normal over western Greece, North Macedonia, Albania, and Italy, with around 80\% of normal precipitation. For Bulgaria and Serbia, spring ended slightly wetter than normal.

During summer, nationally averaged precipitation was $110 \%-130 \%$ of normal across the whole region. Only Sicily and eastern Bulgaria received below-normal rainfall. The season started with a wetter-than-normal June for most of the region, with precipitation 122\%-160\% of normal; Albania and North Macedonia reported below-normal precipitation ( $70 \%-80 \%$ of normal). In July, the distribution of precipitation was inhomogeneous. Italy and North Macedonia reported near-normal precipitation. For Serbia and Albania, the month was drier than normal, with only $50 \%-60 \%$ of normal rainfall, while Slovenia reported $128 \%$ of its normal precipitation. With the exception of eastern Bulgaria, summer ended wetter than normal for the Balkan Peninsula in August. Nationally averaged precipitation ranged from $110 \%$ of normal in Slovenia to above $380 \%$ in North Macedonia (its wettest summer on record).

Precipitation was near normal for Slovenia, Croatia, Italy, and Malta during autumn, while it was drier than normal for Serbia, North Macedonia, Albania, Montenegro, Bosnia and Herzegovina, and Bulgaria. Most of Serbia, Albania, North Macedonia, and Greece received only $40 \%-80 \%$ of their normal precipitation. September was drier than normal in Bulgaria and North Macedonia with $60 \%-80 \%$ of normal precipitation. Italy, Slovenia, and Serbia reported slightly above normal (111\%-118\%) precipitation. Montenegro, Albania, and the southwestern parts of Greece received 
$130 \%-170 \%$ of normal precipitation. October was wetter than normal for most countries of the region, with precipitation $120 \%-160 \%$ of normal. However, it was drier than normal in Malta (33\% of normal), North Macedonia (44\%), and large parts of Greece (40\%-80\%). The season ended with an exceptionally dry November for the region. In many areas, rainfall did not exceed $50 \%$ of normal. Serbia reported only $14 \%$ of its normal precipitation, and Albania and Macedonia received less than 5\%. For North Macedonia, it was the driest November on record. While Italy reported countrywide precipitation of $50 \%$ of normal, it was especially dry in the north where rainfall was well below $20 \%$ of normal. Slovenia reported $34 \%$ of its normal precipitation.

\section{(III) NOTABLE EVENTS AND IMPACTS}

On 2 and 3 March, the western Mediterranean and the Balkans experienced unusually high maximum temperatures due to warm air inflow east of a deep trough. Italy, Albania, and Greece recorded temperatures around $23^{\circ}-25^{\circ} \mathrm{C}$ (normal March maxima are about $15-16^{\circ} \mathrm{C}$ in that area).

Between 12 and 22 May, Italy and the southern Balkans experienced an extreme heat wave. In southern Italy, temperatures around $40^{\circ} \mathrm{C}$ were recorded. Temperatures in the southern Balkans were between $33^{\circ} \mathrm{C}$ and $38^{\circ} \mathrm{C}$. Some of the reported temperatures were the highest since 1945 for that time of year. Following the end of the heat wave, heavy thunderstorms with hail occurred over the Balkans. Walnut-sized hail, which caused damage to agriculture, buildings, and cars, was reported in Serbia.

After thunderstorms accompanied by heavy rain, Serbia and Bosnia experienced heavy flooding during 21-23 June. Some municipalities in central and western Serbia declared a state of emergency after overflowing rivers caused widespread damage to bridges, roads, power lines, and around 700 homes. The station Loznica recorded a daily precipitation of $210 \mathrm{~mm}$ on 23 June (weekly total was $304 \mathrm{~mm}$ ). Bosnia reported flooding, landslides, blocked roads, and damage to roads, bridges, and houses in the region between Tuzla and Sarajevo. On 16 June, a heavy hailstorm caused flooding in the region of Drama in northern Greece. The storm lasted for more than half an hour and in some areas, the hail layer reached a thickness of 30-40 cm.

After a storm during the night of the 6-7 July, large parts of the city of Sofia (Bulgaria) were flooded. Many Metro stations, buildings, and underpasses were submerged.

On 29 July, a supercell caused an extreme hailstorm, with hail reaching diameters of $10 \mathrm{~cm}$ over central Slovenia. This caused extensive damage in the area from the towns of Vodice to Domzale in central Slovenia. The city of Palermo (Sicily) was hit by a thunderstorm, which brought more than $100 \mathrm{~mm}$ of rain in 3 hours. Severe flooding overwhelmed the sewer system and cars were swept away. The weather station at the astronomical observatory in Palermo recorded a new July daily precipitation record of $74 \mathrm{~mm}$ in a series reaching back to 1794 .

Thunderstorms accompanied by heavy rain caused flash flooding on the island of Evia in central Greece on 8-9 August. Within a few hours, 200-300 mm were recorded on parts of the island, which is about $80 \%$ of its annual precipitation. At least seven people lost their lives.

At least four people were killed during a heavy thunderstorm accompanied by egg-sized hail on 29 and 31 August in northern Italy.

During 17-18 September, the medicane "Udine” ("Ianos” in Greece) caused heavy damage to roads, ports, and the power grid, as well as flooding in the Ionian Sea and mainland Greece. Precipitation estimates based on satellite, station, and model data were $186 \mathrm{~mm}$ over the Ionian Sea and $123 \mathrm{~mm}$ over western Greece mainland in 32 hours. (See Sidebar 4.2 for more information on medicanes in 2020).

On 9-10 November, more than $150 \mathrm{~mm}$ fell in 24 hours over some areas on Crete Island (Greece), causing flash flooding. Vehicles, roads, and houses were damaged. At least 79 people had to be rescued. After more than $450 \mathrm{~mm}$ of rain fell during 20-22 November in southern Italy, a state of emergency was declared in the Calabria region due to severe flooding that caused widespread damage. 


\section{7) Eastern Europe}

This region includes European part of Russia, Belarus, Ukraine (1961-90 base period), Moldova and Romania, and west Kazakhstan.

\section{(I) TEMPERATURE}

The year was exceptionally warm for eastern Europe, with temperatures more than $+2.0^{\circ} \mathrm{C}$ above average for most countries. It was the warmest year on record for the European part of Russia $\left(+2.9^{\circ} \mathrm{C}\right)$, Belarus $\left(+2.3^{\circ} \mathrm{C}\right)$, Ukraine $\left(+2.2^{\circ} \mathrm{C}\right)$, Moldova $\left(+2.0^{\circ} \mathrm{C}\right)$, and Kazakhstan $\left(+2.3^{\circ} \mathrm{C}\right)$. Romania reported its second-warmest year $\left(+1.7^{\circ} \mathrm{C}\right)$. During winter, anomalies were well above $+3.0^{\circ} \mathrm{C}$; Romania reported the lowest monthly anomaly of $+1.7^{\circ} \mathrm{C}$ for the whole region and season in January. It was the warmest winter on record for European Russia $\left(+5.4^{\circ} \mathrm{C}\right.$ above normal), Belarus $\left(+5.1^{\circ} \mathrm{C}\right)$, Ukraine $\left(+4.0^{\circ} \mathrm{C}\right)$, Moldova $\left(+3.8^{\circ} \mathrm{C}\right)$, and Kazakhstan $\left(+5.4^{\circ} \mathrm{C}\right)$, while it was second warmest for Romania $\left(+3 \cdot 1^{\circ} \mathrm{C}\right)$.

Spring started with a warmer-than-normal March. Anomalies ranged from $+2.6^{\circ} \mathrm{C}$ in Romania to above $+6.2^{\circ} \mathrm{C}$ in Kazakhstan. It was the warmest March on record in European Russia $\left(+5.9^{\circ} \mathrm{C}\right.$ anomaly, 1961-90 base period). During April, only Moldova and Romania reported above-normal temperatures, while the other countries reported temperatures ranging from $-0.8^{\circ} \mathrm{C}$ below normal in Belarus to near normal in Ukraine. The season closed with a colder-than-normal May for most of the region, except for Kazakhstan $\left(+2.0^{\circ} \mathrm{C}\right.$ above normal) and some eastern parts of European Russia. Anomalies in Belarus, Ukraine, and Moldova were around $-2.2^{\circ} \mathrm{C}$, while Romania reported $-1.3^{\circ} \mathrm{C}$ below normal.

During summer, the entire region experienced temperatures $+1.0^{\circ}$ to $+1.3^{\circ} \mathrm{C}$ above normal. For most of the region, June was the warmest of the summer months; only Romania reported an anomaly lower than $+1.0^{\circ} \mathrm{C}$. During July, temperatures were below normal for Belarus (anomaly of $-0.6^{\circ} \mathrm{C}$ ) and some areas of northwestern Russia. In the Ukraine, Moldova and Romania temperature anomalies were $+0.5^{\circ}$ to $+0.8^{\circ} \mathrm{C}$. In Kazakhstan, temperatures were $+3.2^{\circ} \mathrm{C}$ above normal. August was colder than normal in Kazakhstan, at $-1.2^{\circ} \mathrm{C}$ below normal while Belarus and Ukraine reported anomalies around $+1.0^{\circ} \mathrm{C}$. For Romania and Moldova, temperatures were $+1.6^{\circ}$ and $+1.7^{\circ} \mathrm{C}$ above normal, respectively.

With the exception of Kazakhstan, the entire region experienced an unusually warm autumn. For Belarus, Romania, and the Ukraine it was the warmest September on record, with reported anomalies of $+2.6^{\circ},+3.2^{\circ}$, and $+3.5^{\circ} \mathrm{C}$, respectively. In Moldova, temperature anomalies were above $+4.0^{\circ} \mathrm{C}$. The warmth continued in October; Romania observed its second-warmest October on record $\left(+2.8^{\circ} \mathrm{C}\right.$ above normal), while European Russia was record warm $\left(+3.4^{\circ} \mathrm{C}, 1961-90\right.$ base period). Belarus reported temperatures $+3.8^{\circ} \mathrm{C}$ above normal, and in the Ukraine and Moldova, anomalies reached above $+4.0^{\circ} \mathrm{C}$, each ranking October 2020 among their five warmest Octobers on record.

\section{(II) PRECIPITATION}

The year was slightly drier than normal across the region, with $86 \%-96 \%$ of normal precipitation; Kazakhstan reported a lower value of $72 \%$ of normal. The areas around the Black Sea, southern Russia, and Kazakhstan received the least precipitation.

During winter, the Ukraine and Belarus received near-normal precipitation. Moldova and Romania reported below-normal precipitation of 50\% and $80 \%$ of normal, respectively. Except for Russia, which reported normal precipitation, January was drier than normal. Belarus and Kazakhstan received $80 \%-90 \%$ of their normal precipitation and the Ukraine $55 \%$ of its normal. For Moldova and Romania, January ranked as the second and third driest on record, with only 23\% and $30 \%$ of normal precipitation, respectively. In February, most of the region received around $150 \%$ of normal precipitation. Only Belarus reported near-normal precipitation. 
Spring was slightly wetter than normal for European Russia and near normal for the Ukraine. Belarus, Romania, Moldova, and Kazakhstan received $70 \%-80 \%$ of their normal precipitation. During March, only some areas in the southwest of Romania and most of northern Russia received above-normal precipitation. Belarus reported around 70\%, the Ukraine 68\%, Romania 110\%, and Kazakhstan and Moldova each 50\% of normal precipitation. For Belarus, the Ukraine, Moldova, and Romania, April was very dry with nationally averaged precipitation below $40 \%$ of normal, and even less in localized areas. Romania reported its driest April on record. Spring ended with a wetter-than-normal May for most of the region, with countrywide precipitation $110 \%-174 \%$ of normal. The Ukraine had its second-wettest May, with 174\% of normal precipitation.

Summer was drier than normal for the Ukraine and Moldova, with $80 \%$ of normal precipitation. Many areas in southern Russia and Kazakhstan received only 40\%-80\% of their normal precipitation. Although some areas received above-normal precipitation, June and July were drier than normal for Russia and Kazakhstan. Most of Kazakhstan received less than 20\%-40\% of normal precipitation in June; however, for Belarus, Moldova, and Romania, precipitation was $120 \%-155 \%$ of normal. While some eastern areas in the Ukraine received below-normal rainfall, overall precipitation was slightly above normal for the country. July rainfall was near normal for Romania and drier than normal for Belarus, the Ukraine, and Moldova with $60 \%-90 \%$ of normal precipitation. Summer ended with above-normal precipitation for Kazakhstan (around $130 \%$ of normal) and some parts of Russia in August. Meanwhile, the Ukraine reported only 43\% of normal precipitation and Romania received 70\%, marking its third-driest August on record.

The Ukraine and Romania reported near-normal rainfall for autumn. Belarus received around $80 \%$ of its normal precipitation. For most of Kazakhstan and many areas of European Russia, precipitation was $40 \%-60 \%$ of normal. The season started with near-normal precipitation in September for the Ukraine and Romania, while Belarus received around $70 \%$ of its normal. While overall Russia received $80 \%$ of normal precipitation, it was especially dry in southern European Russia where large areas received less than $20 \%$ of normal precipitation. October was wetter than normal for the western countries of the region: Belarus, the Ukraine, Moldova, and Romania received $110 \%-170 \%$ of normal precipitation. In Kazakhstan, rainfall was very low-around 20\% of normal. While overall Russia received around 70\% of normal precipitation, the south was very dry again with around $20 \%$ of normal precipitation in some areas. The season concluded with below-normal rainfall across most of the region, with nationally averaged precipitation of $40 \%-80 \%$ of normal in November.

\section{(III) NOTABLE EVENTS AND IMPACTS}

Due to manmade grass burning and favorable dry conditions together with strong winds, on 4 April wildfires broke out in areas heavily contaminated by the Chernobyl nuclear accident. The fires reached the Exclusion Zone about $1 \mathrm{~km}$ from the power plant, where radioactive contamination is the highest. The fire was taken under control only after 10 days and an area of at least 20,000 ha burned. Due to the fire, significantly elevated levels of cesium 137 were measured in the air in Kiev, which, according to the Institute for Radiological Protection and Nuclear Safety (IRSN), posed no risk to health.

Between 8 and 17 June, extremely high temperatures were measured in Russia up to the Arctic circle. Many stations reported temperatures up to $32^{\circ} \mathrm{C}$, which is around $+20^{\circ} \mathrm{C}$ above normal. On 9 June, the station Nizhnyaya Pesha located at $66.7^{\circ} \mathrm{N}$ measured a temperature of $30.3^{\circ} \mathrm{C}$. A new daily maximum record of $31.4^{\circ} \mathrm{C}$ was set in Moscow on 17 June.

Following heavy rain on 22-23 June, overflowing rivers damaged roads, bridges, and power lines in western Ukraine. Approximately 7500 homes were flooded, over 470 people were displaced, and three people were killed. 
A combination of significantly above-average temperatures and precipitation deficits $(60 \%-75 \%$ of normal) during autumn in European Russia resulted in significant below-average winter grain crop moisture (relative to 2000-19) in the Southern Federal District, in certain regions of the Central Federal District, and the Volga Federal Districts of Russia.

\section{8) Middle East}

This region includes Israel, Cyprus, Jordan, Lebanon, and Syria.

\section{(I) TEMPERATURE}

Overall, the year was warmer than usual across the Middle East, with temperatures $+1.1^{\circ}$ to $+1.5^{\circ} \mathrm{C}$ above normal. It was the third-warmest year on record for Cyprus and Jordan and the fourth warmest for Syria.

Winter was slightly warmer than normal for the region, except for Cyprus where the anomaly was close to $+1.0^{\circ} \mathrm{C}$. January had temperatures that were near to slightly below normal. The season ended with February anomalies close to $+1.0^{\circ} \mathrm{C}$ across the region, except for Syria, which reported near-normal temperatures.

Spring started with a warmer-than-usual March, with anomalies close to $+1.5^{\circ} \mathrm{C}$ for all countries of the region. April was near normal, but in May, anomalies were above $+1.5^{\circ} \mathrm{C}$, except in Syria $\left(+0.5^{\circ} \mathrm{C}\right.$ above normal). Cyprus and Israel each reported their third-warmest May on record (anomalies of $+2.5^{\circ} \mathrm{C}$ and $+1.8^{\circ} \mathrm{C}$, respectively).

Summer temperatures ranged from $+0.6^{\circ} \mathrm{C}$ above average in Syria to $+1.0^{\circ} \mathrm{C}$ in Jordan. June was near to below normal for most of the region. Except for Jordan (anomaly $+0.6^{\circ} \mathrm{C}$ ), anomalies ranged from $-0.3^{\circ} \mathrm{C}$ (Syria) to $+0.2^{\circ} \mathrm{C}$ (Israel). July was the warmest month of the season; anomalies for Cyprus and Israel were $+1.0^{\circ} \mathrm{C}$. Jordan and Syria reported their third-warmest July with anomalies of $+3.0^{\circ}$ and $+1.6^{\circ} \mathrm{C}$, respectively. August temperatures were a little more than $+1.0^{\circ} \mathrm{C}$ higher than normal for Cyprus and Israel, while the anomaly for Syria was close to $+0.5^{\circ} \mathrm{C}$. August was slightly cooler than normal for Jordan.

Autumn was exceptionally warm for the entire Middle East; most countries observed temperatures more than $+2.0^{\circ} \mathrm{C}$ above normal. Cyprus and Syria each reported their warmest autumn on record, with anomalies of $+2.6^{\circ}$ and $+2.5^{\circ} \mathrm{C}$, while it was second warmest for Israel and Jordan, at $+2.1^{\circ}$ and $+2.8^{\circ} \mathrm{C}$, respectively. September was the warmest on record for all countries in the region and October was warmest on record for all except Israel (third warmest). September anomalies ranged from $+2.8^{\circ} \mathrm{C}$ in Israel to $+4.3^{\circ} \mathrm{C}$ in Jordan. During October, anomalies were not quite as high but still well above $+2.0^{\circ} \mathrm{C}$ (Cyprus $+3.0^{\circ} \mathrm{C}$; Syria $+2.5^{\circ} \mathrm{C}$; Israel $+2.2^{\circ} \mathrm{C}$; Jordan $+3.4^{\circ} \mathrm{C}$ ). For Cyprus, the November temperature was nearly $+2.0^{\circ} \mathrm{C}$ above normal, while anomalies were close to $+1.0^{\circ} \mathrm{C}$ across the rest of the region.

\section{(II) PRECIPITATION}

During the year, except for Syria, the Middle East received above-normal precipitation. For Cyprus and Israel, precipitation was around $160 \%$ of normal and for Jordan it was $120 \%$ of normal. For Syria, the year was wetter than normal in the west and drier than normal in the east.

Winter was wetter than normal; many areas received precipitation above $125 \%$ of normal and above $167 \%$ of normal in localized areas. During January, the northern and western parts of the region were wetter than normal. In February, southern Israel and many parts of Jordan were wetter than normal, while many parts of Syria received only $20 \%-60 \%$ of normal precipitation (even less in central Syria).

While spring was wetter than normal overall (except for large areas in central Syria and northern Jordan), precipitation was distributed very inhomogeneously over the months. After a wetter-than-normal season start in March, large areas of the Middle East received well below $20 \%$ of normal precipitation in April. For the most western parts of Syria, Lebanon, and Israel, 
precipitation was around 125\% of normal. Localized areas in southern Jordan received abovenormal precipitation of around 500\%. In May, only northern Israel, northwestern Jordan, and Lebanon received above-normal precipitation; only 20\%-60\% of normal was received elsewhere.

Summer was especially dry. Large parts of Israel and Syria received almost no precipitation at all during their dry season. In Cyprus, precipitation was around 80\% of normal. Most of Jordan, especially the north, received little precipitation. For Cyprus, Syria, Lebanon, and Israel all summer months were drier than normal with precipitation totals of mostly $0 \%-30 \%$ of normal. Precipitation was above normal for Jordan, southern Israel, and southeastern Syria in July.

At the beginning of autumn, only localized areas observed some precipitation in northern Jordan, otherwise the Middle East received precipitation well below 20\% of normal or none at all. The dry September was followed by an extremely dry October, with most of the area receiving no precipitation, which led to the whole Middle East experiencing an extreme drought. November was wetter for most of the region, where precipitation ranged from $125 \%-250 \%$ above normal (except for northwestern Syria).

\section{(III) NOTABLE EVENTS AND IMPACTS}

From 25 December 2019 to 10 January 2020, storm activity with exceptionally high precipitation led to flooding, heavy damage to property, and casualties in Cyprus, Syria, Lebanon, and Israel. On 4 January, $74 \mathrm{~mm}$ of precipitation was measured within 2 hours in Tel Aviv, which is around $20 \%$ of the annual rainfall. On 8 January, a daily total of $97 \mathrm{~mm}$ was measured in Haifa. The Haifa Center Hashoma railway station was completely flooded after the area received a downpour of $50 \mathrm{~mm}$ in less than 2 hours. Within 24 hours, the Sea of Galilee rose by $23 \mathrm{~cm}$. Overall, during this period, average rainfall totals of $350-400 \mathrm{~mm}$ occurred (550 $\mathrm{mm}$ in localized areas). This was the highest 2-week total since January 1969 and the third highest in the last 80 years. For some areas in the south, precipitation surpassed monthly and seasonal normals and broke a 76-year old record. In Cyprus, some of the largest water reservoirs were completely filled and even overflowing the dam walls (an all-time record) after heavy rain between 6 and 8 January. Following these events, Syria and Lebanon experienced snowstorms due to cold air inflow, with Lebanon measuring snow depth of $130 \mathrm{~cm}$ in Kfardebian (1900-m altitude) on 10 January.

On 18 February an extreme cold spell with temperatures as low as $-11^{\circ} \mathrm{C}$, accompanied by heavy snow and ice storms, made living conditions for over 80,000 displaced people difficult. At least seven children including one baby froze to death.

After heavy precipitation between 9 and 11 April, the water level of the Sea of Galilee rose up to only 6-21 cm below maximum capacity and thus close to completely full for the first time since 1992. The abundant rainfall that started in January increased the water levels by $3.12 \mathrm{~m}$. All of Israel had received more than its normal annual precipitation totals by this time.

At the beginning of May, intense and unusual thunderstorms were observed across Israel (typically, the dry season has already begun around this time of year). On 5 May, 828 lightning strikes were observed (monthly normal is 30). Heavy rain and hail led to flooding and highway blockages. During 23 and 24 May, unusually late snow was observed on Mount Hermon (2814 m a.s.l.).

During an exceptional heat wave at the beginning of September, many countries in the Middle East reported new maximum temperature records; in Hassakah (Syria) $47.0^{\circ} \mathrm{C}$ was measured on 3 and 4 September; Houche-Al-Oumara (Lebanon) $44.3^{\circ} \mathrm{C}$ on 3 September; Gecitkale (Cyprus) $45.8^{\circ} \mathrm{C}$ on 4 September; and $48.5^{\circ} \mathrm{C}$ at Aqaba Airport (Jordan) on 5 September. Eilat (south Israel) reached $48.9^{\circ} \mathrm{C}$ on 4 September, setting both a monthly and an all-time maximum temperature over the 70 year-long record. On 3 September, two new monthly records were broken in Jerusalem; a new maximum temperature of $41.2^{\circ} \mathrm{C}$ was measured for the 118 -year-long record, and the temperature did not drop below $31^{\circ} \mathrm{C}$ the following night. In Kefar Blum, a maximum temperature above $40^{\circ} \mathrm{C}$ occurred on eight consecutive days. 
Following an October with no precipitation at all for Israel, exceptionally intense rain during 20-22 November caused severe flooding of houses, roads, and cars. Around Mount Carmel, 24-hour totals of $230 \mathrm{~mm}$ (the highest since 1998) were measured. Other areas of the country received 100-150 mm of rainfall during this time, which was more than double the monthly normal.

\section{9) Turkey and South Caucasus}

This region includes Turkey, Armenia, Georgia, and Azerbaijan.

\section{(I) TEMPERATURE}

Overall, the year was warmer than normal for the region with annual temperatures $+1.0^{\circ}$ to $+1.6^{\circ} \mathrm{C}$ above normal. The year started with a warmer-than-normal winter. Turkey observed temperatures that were $+1.4^{\circ} \mathrm{C}$ above normal, while anomalies for Armenia, Georgia, and Azerbaijan were around $+2.0^{\circ} \mathrm{C}$. Armenia reported its second-warmest January and February on record.

Spring started with an exceptionally warm March, with temperatures more than $+4.0^{\circ} \mathrm{C}$ above normal almost everywhere in eastern Turkey and the South Caucasus. After a colder-than-normal April for the South Caucasus (anomalies between $-1.0^{\circ} \mathrm{C}$ and $-2.0^{\circ} \mathrm{C}$ ) and near normal for Turkey, May was warmer than normal, with temperatures about $+1.0^{\circ} \mathrm{C}$ above normal.

For most of the region, summer was only slightly warmer than normal, with anomalies of around $+0.6^{\circ} \mathrm{C}$; Georgia and some parts of northern Turkey observed anomalies above $+1.0^{\circ} \mathrm{C}$. For Turkey, the season started with a near-normal June while in the South Caucasus anomalies were well above $+2.0^{\circ} \mathrm{C}$. July temperatures were around $+1.3^{\circ} \mathrm{C}$ above normal, except in Georgia with around $+2.0^{\circ} \mathrm{C}$ anomalies. August was colder than normal in eastern Turkey and the South Caucasus. Anomalies were slightly below $-2.0^{\circ} \mathrm{C}$ in Armenia and Azerbaijan.

Due to a very warm September and October, autumn was exceptionally warm, especially for Turkey, which reported its warmest autumn on record $\left(+2.5^{\circ} \mathrm{C}\right.$ above normal). Georgia and Armenia also reported anomalies of $+2.0^{\circ} \mathrm{C}$, while in Azerbaijan it was close to $+1.0^{\circ} \mathrm{C}$ above normal. Both Georgia and Armenia reported September and October monthly anomalies above $+2.5^{\circ} \mathrm{C}$. In most of Turkey, temperature anomalies were well above $+3.0^{\circ} \mathrm{C}$ and even higher in localized areas, making both September and October the warmest on record.

\section{(II) PRECIPITATION}

Annual precipitation was distributed inhomogeneously for Turkey and Armenia during 2020, but were close to normal on balance: the southern parts of the region and also some parts of Turkey (Mersin, Giresun, Trabzon, Şirnak, Adiyaman, Diyarbakir, Hakkari, Batman Kirklareli) received above -normal precipitation while the northern parts were drier than normal. Overall, precipitation for Turkey was $87 \%$ of its annual normal. Georgia received only $80 \%$ of its normal precipitation. For Azerbaijan, the year was slightly wetter than normal.

During winter, Turkey received above-normal precipitation of about $110 \%$, even though precipitation was below normal in the east and west. Georgia and Armenia reported precipitation totals that were $75 \%$ of normal. The distribution of precipitation in January was inhomogeneous in Turkey, with some parts in the east and west receiving $40 \%-80 \%$ of normal while precipitation was above normal in other areas. Armenia reported $43 \%$ of its normal and Georgia overall received near-normal precipitation. Winter ended with near-normal precipitation in February for most of the South Caucasus and slightly wetter than normal for Turkey (115\% of normal).

During spring, the region received around 115\% above-normal precipitation except in western Turkey where precipitation was below normal (locally as low as $80 \%$ of normal). Except for western and central Turkey in March and April, all months were slightly wetter than normal in most of the region but up to $170 \%$ of normal in localized areas.

Summer was drier than normal for both Georgia and Armenia with only 90\% of normal precipitation. Azerbaijan received around $115 \%$ of its normal precipitation. While some southern regions 
in Turkey were drier than normal, nationally averaged precipitation was slightly above normal. For the South Caucasus, only June was drier than normal, while it was wetter than normal for Turkey. During July and August, western and central Turkey received below-normal precipitation, as low as $20 \%$ of normal in some places.

During autumn, precipitation was between $40 \%-60 \%$ of normal almost everywhere in the region. September and October were notably dry. Only some local areas in western Turkey received above-normal precipitation during those months. September precipitation was $40 \%$ of normal on average. During October, rainfall totals were even lower in many areas. Eastern Turkey received less than 20\% of its normal precipitation and Georgia received around 30\% of its normal. On average, November precipitation was around $80 \%$ of normal for the region, although some parts of eastern Turkey received precipitation up to $169 \%$ of normal.

\section{(III) NOTABLE EVENTS AND IMPACTS}

During 6-7 January, heavy winds, rain, and snow affected large areas of Turkey. The southern province of Mersin received around $165 \mathrm{~mm}$ of precipitation in 24 hours, causing heavy flooding and landslides. At least two people were killed. In some parts of Istanbul, more than $110 \mathrm{~mm}$ of precipitation fell in 24 hours and wind gusts over $104 \mathrm{~km} \mathrm{~h}^{-1}$ were measured. Flooding caused traffic disruptions and strong winds damaged over 100 buildings.

In February, Turkey experienced an extensive cold spell with snowstorms, blizzards, and extremely cold temperatures. Roads were blocked by snow or closed due to risk of avalanches. During the night of 9-10 February, a new local record low temperature of $-40^{\circ} \mathrm{C}$ was recorded in Gole (Ardahan Province, northeastern Turkey). On 21 February, a blizzard hit southeastern Turkey and buried a village under about $6 \mathrm{~m}$ of snow. Seventy villages were isolated and electricity and water supplies were disrupted.

On 29 July, heavy precipitation caused flooding in western Georgia (upper Racha province). Floods and mudslides caused heavy damage to roads and bridges, which isolated over 2000 people. The water and electricity supply was disrupted for 400 homes. In the Guria area at the Black Sea coast, agriculture fields, roads, and power lines were damaged.

\section{g. Asia-T. Li, Ed.}

Throughout this section the base periods used vary by region. The current standard is the 1981-2010 average for both temperature and precipitation, but earlier base periods are still used in several countries. All seasons mentioned in this section refer to those of the Northern Hemisphere (NH), with winter referring to December-February 2019/20, unless otherwise noted.

\section{1) Overview-T. Li, Z.Zhu, P.Zhang, T. C. Lee, S. Supari, M. Hanafusa, Hir. Sato, S. Wakamatsu, G. S. Im, D. Dulamsuren, A. Moise,}

M-V. Khiem, and H-P. Lam

Annual mean surface air temperatures during January-December 2020 were above normal across most of Asia, with dominating positive anomalies above $+3.0^{\circ} \mathrm{C}$ in Siberia and other positive anomalies exceeding $1.0^{\circ} \mathrm{C}$ from the eastern part of East Asia to the Indochina Peninsula (Fig. 7.41). Annual precipitation totals were above normal (>120\%) from western to central Siberia, in the eastern part of East Asia, from western India to Pakistan, and southeast of Arabian Peninsula, and below normal ( $<80 \%)$ in western Central Asia and western China (Fig. 7.42).

In winter, positive temperature anomalies dominated Siberia and much of Asia, except from western China to northern India (Fig. 7.43a). Seasonal precipitation was below normal across much of Southeast Asia (Fig. 7.43b) and much above normal in northeast China. In spring, dominating positive temperature anomalies continued across much of Siberia (Fig. 7.43c). In summer, positive temperature anomalies were observed in northern Siberia, from Japan to the Korean Peninsula, and from southeastern China to the Indochina peninsula (Fig. 7.43e). The eastern part of East Asia experienced above-normal precipitation (Fig. 7.43f). In autumn, much-above-normal 


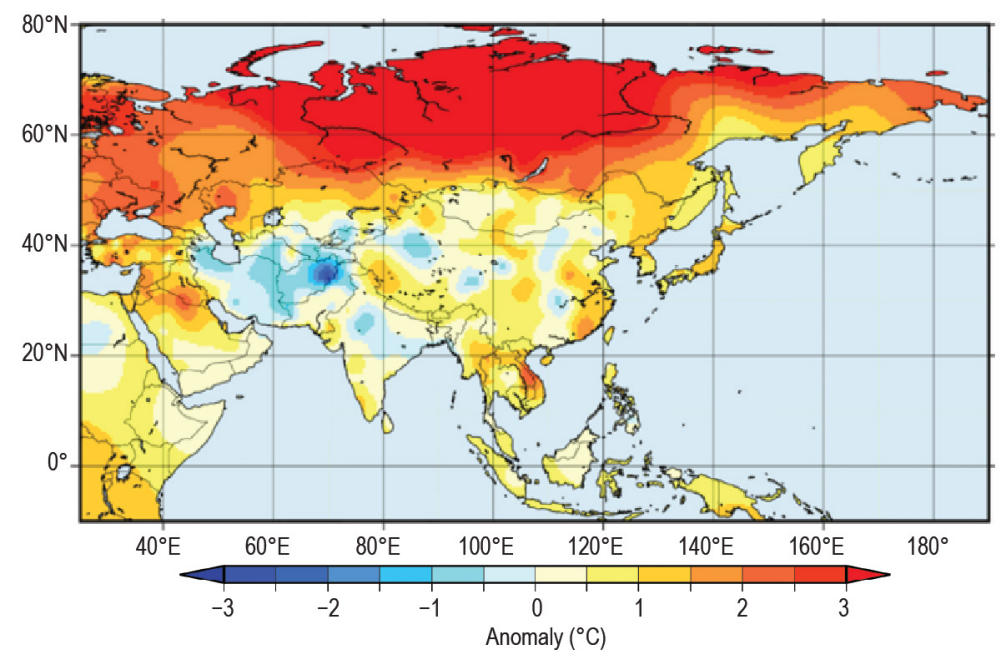

Fig. 7.41. Annual mean surface temperature anomalies $\left({ }^{\circ} \mathrm{C}\right.$; 1981-2010 base period) over Asia in 2020. (Source: Japan Meteorological Agency.)

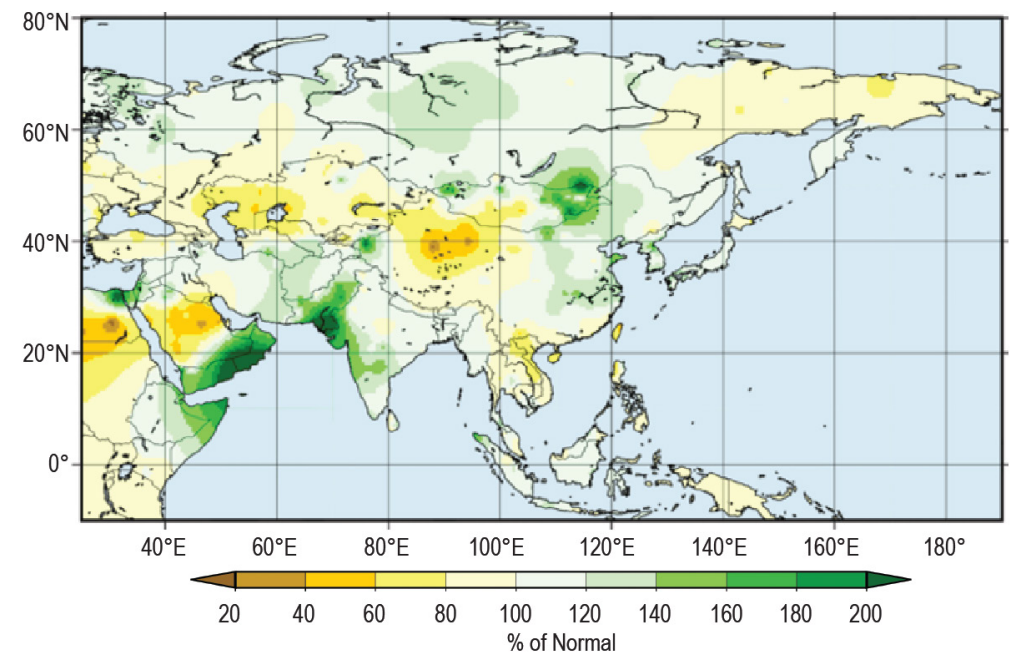

Fig. 7.42. Annual precipitation (\% of normal; 1981-2010 base period) over Asia in 2020. (Source: Japan Meteorological Agency.) temperatures prevailed in Siberia, while temperatures were below normal from northwestern China to Central Asia (Fig. $7.43 \mathrm{~g}$ ). The seasonal precipitation total was above normal in and around southern India due to late withdrawal of the monsoon season (Fig. 7.43h) and above normal in northeast China.

In winter, positive 500-hPa geopotential height anomalies and 850-hPa temperature anomalies occurred from Siberia to East Asia (Fig. 7.44a) and notably continued over a wide area of Siberia during spring (Fig. 7.44b). Also in spring, convective activity was suppressed over the South China Sea (Fig. 7.45b), which was accompanied by the southward shift of the subtropical jet stream over Eurasia. In summer, lower-tropospheric anti-cyclonic circulation anomalies straddling the equator were present over the western tropical Pacific; these anomalies were associated with enhanced convection over the western Indian Ocean and suppressed convection over the western Pacific, respectively (Fig. 7.45c). In autumn, convective activity was enhanced from the northern Indian Ocean to the Maritime Continent, and suppressed to the west of the date line in the equatorial Pacific (Fig. 7.45d). In the 500-hPa height field, a wavy anomaly pattern was seen over Eurasia with negative anomalies over Central Asia (Fig. 7.44d).

\section{2) Russia-M. Yu. Bardin and N. N. Korshunova}

Estimates of climate features for Russia are obtained from hydrometeorological observations of the Roshydromet Observation Network. Anomalies are relative to the 1961-90 base period, and national rankings and percentiles reflect the 1936-2020 period of record. Note that the temperature database was extended significantly, which in some cases changed previous ranking. The boundary between Asian Russia and European Russia is considered to be $60^{\circ} \mathrm{E}$.

\section{(I) TEMPERATURE}

The year 2020 in Russia was record warm, with the annual mean temperature $3.2^{\circ} \mathrm{C}$ above normal (Fig. 7.46), exceeding the previous record of $2007\left(2.2^{\circ} \mathrm{C}\right.$ above normal) by a full $1^{\circ} \mathrm{C}$. Both Asian and European Russia were record warmest. Anomalies above the 95th percentile were observed at most stations across the country, except for some coastal regions of the northern Far East. Over vast territories in northern Siberia, annual mean temperatures exceeded the climatology by more than $5^{\circ} \mathrm{C}$ (more than $6^{\circ} \mathrm{C}$ in the Taimyr Peninsula). Seasonally, winter, spring, and autumn each were warmest on record for Russia; summer 2020 was fifth warmest. 

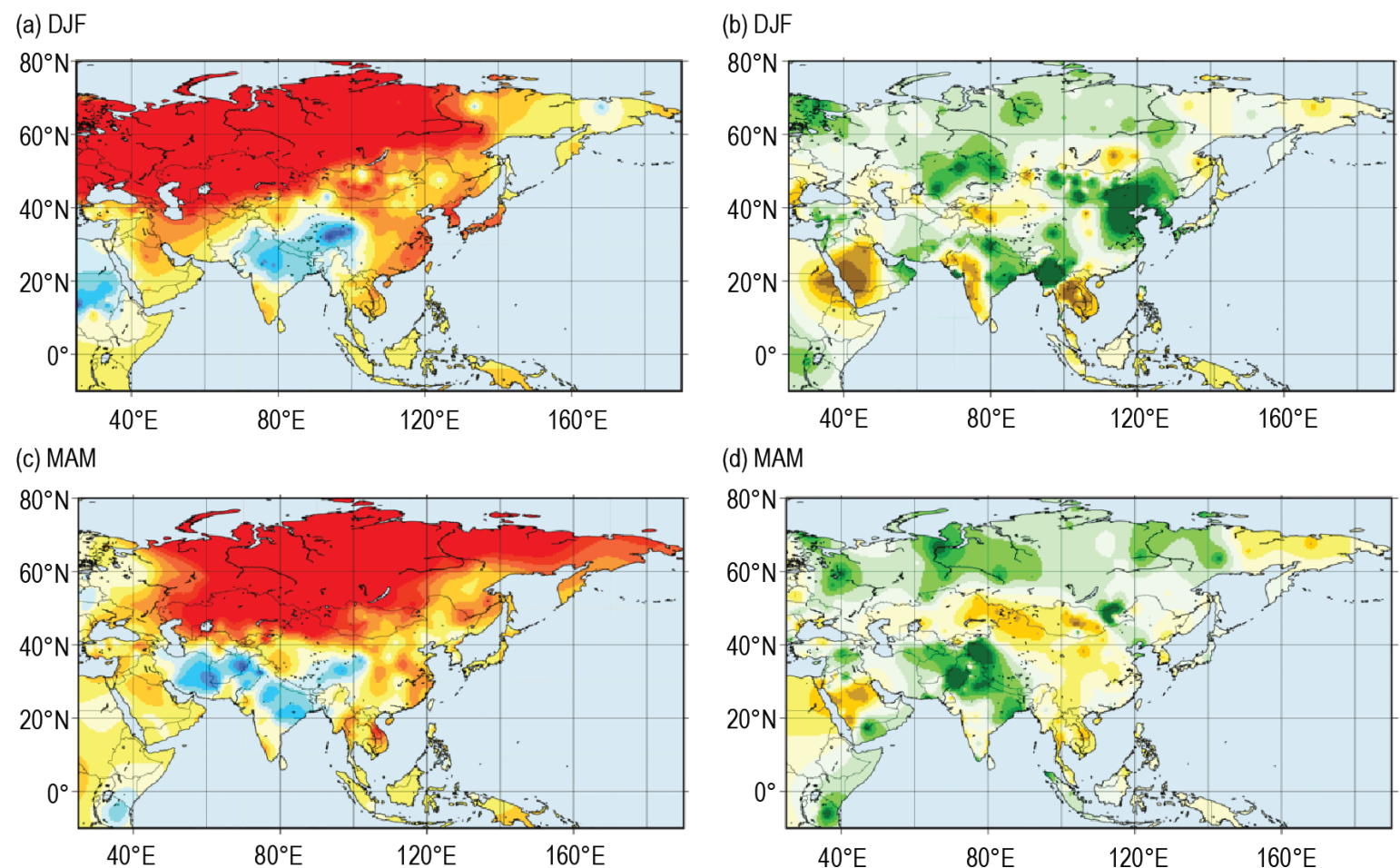

(d) MAM
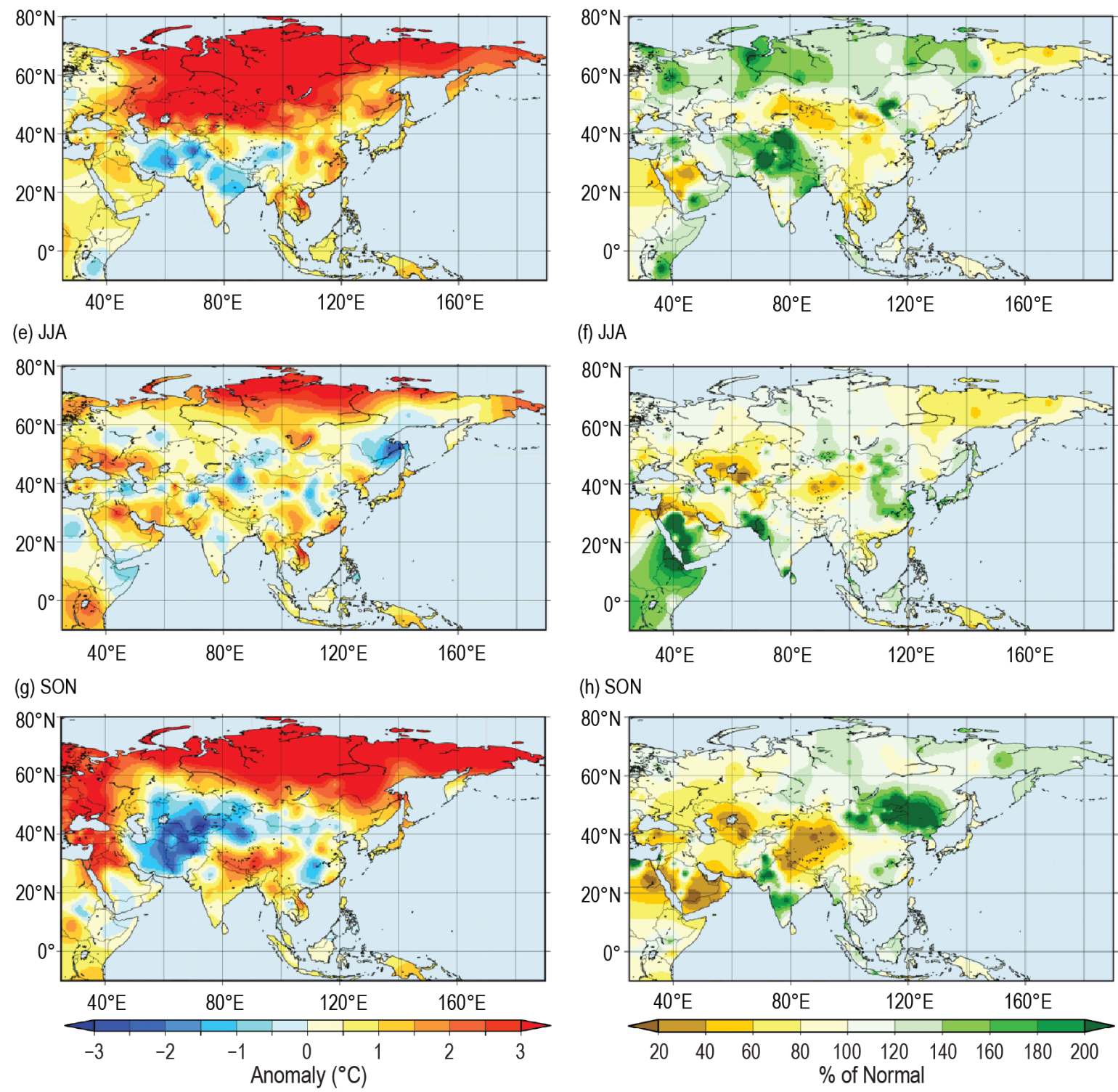

(f) JJA

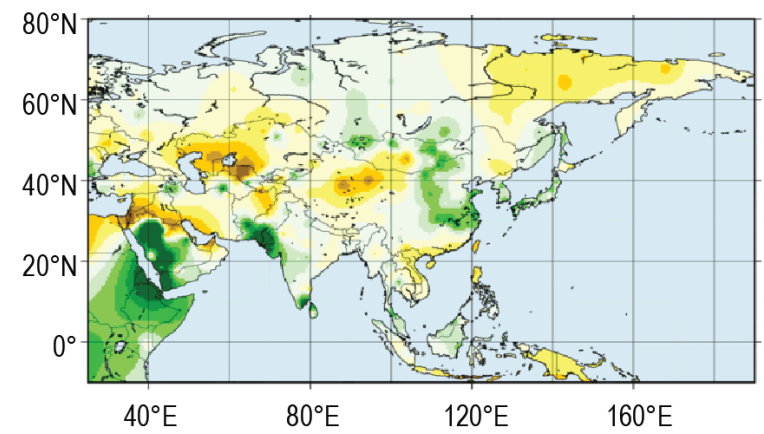

(h) SON

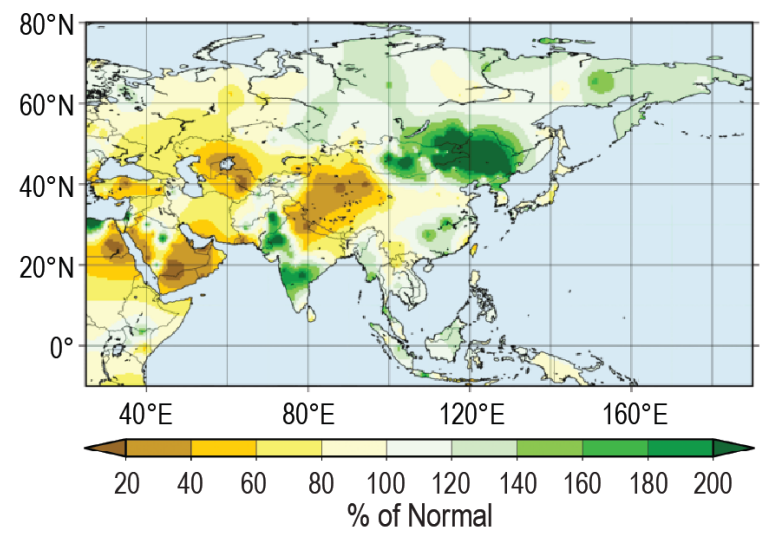

Fig. 7.43. Seasonal mean surface temperature anomalies $\left({ }^{\circ} \mathrm{C}\right.$, left column) and seasonal precipitation (\% of normal, right column) over Asia in 2020 for $(a, b)$ winter; (c,d) spring; (e,f) summer; and (g,h) autumn. All relative to 1981-2010. (Source: Japan Meteorological Agency.) 

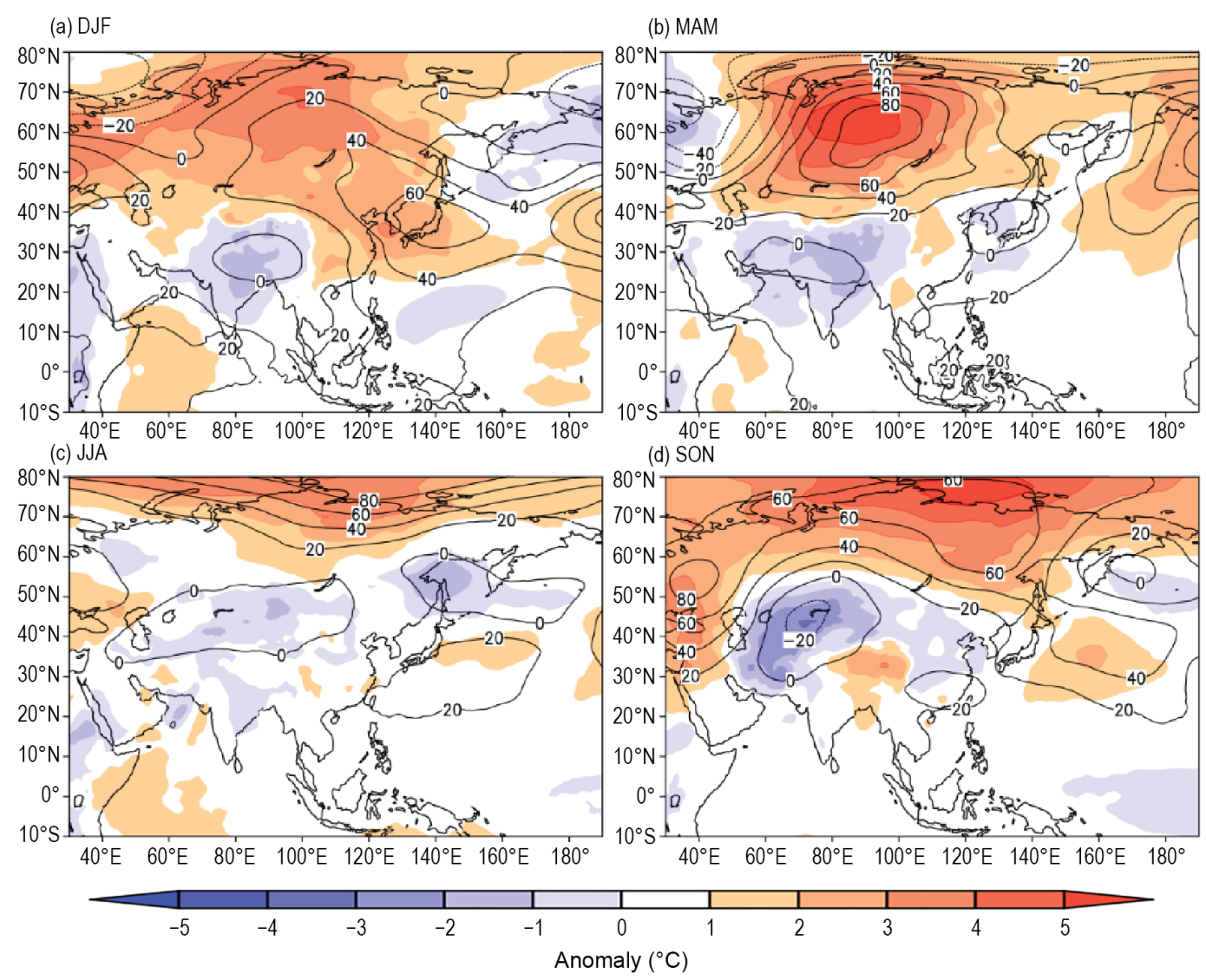

Fig. 7.44. Seasonal mean anomalies of 500-hPa geopotential height (contour, gpm) and 850-hPa temperature (shading, ${ }^{\circ} \mathrm{C}$ ) in 2020 for (a) winter, (b) spring, (c) summer, and (d) autumn, using data from the JRA-55 reanalysis. The base period is 1981-2010. (Source: Japan Meteorological Agency.)


Fig. 7.45. Seasonal mean anomalies of 850 -hPa stream function (contour, $1 \times 10^{6} \mathrm{~m}^{2} \mathrm{~s}^{-1}$ ) using data from the JRA-55 reanalysis and OLR (shading, $\mathrm{W} \mathrm{m}^{-2}$ ) using data originally provided by NOAA in 2020 for (a) winter, (b) spring, (c) summer, and (d) autumn. The base period is 1981-2010. (Source: Japan Meteorological Agency.) 
Winter 2019/20 was warmest on record for both Asian and European Russia. For Russia as a whole, the mean temperature was $5^{\circ} \mathrm{C}$ above normal, $1.5^{\circ} \mathrm{C}$ above the previous warmest winter of $2014 / 15$. European Russia was especially warm $\left(6.8^{\circ} \mathrm{C}\right.$ above normal; $2.5^{\circ} \mathrm{C}$ above the warmest winter of 2015/16) as was Western Siberia, where temperatures were more than $7^{\circ} \mathrm{C}$ above normal almost everywhere. Only the northern Far East was near normal. January was abnormally warm across the country, except in the Chukotka region (Fig. 7.47). Intense westerlies brought European Russia warm air from the Atlantic, and large areas with temperatures $8^{\circ}-12^{\circ} \mathrm{C}$ above normal were observed in its northwestern and central parts. Many stations observed new record high temperatures on 15-17 January. Another strong warm center formed in the Irkutsk and Krasnoyarsk regions of Siberia.

It was a record warm spring for Asian Russia $\left(4.61^{\circ} \mathrm{C}\right.$ above normal). It was especially warm in Western Siberia with temperature anomalies exceeding $+6^{\circ} \mathrm{C}$ everywhere, including the eastern part, where temperatures were $9^{\circ} \mathrm{C}$ above normal. Most stations in the Urals and Siberia reported temperatures above their 95th percentile. March, April, and May were each among their three warmest months on record for both Russia as a whole and for Asian Russia, with May being the warmest month on record. In European Russia, following an abnormally warm winter, March
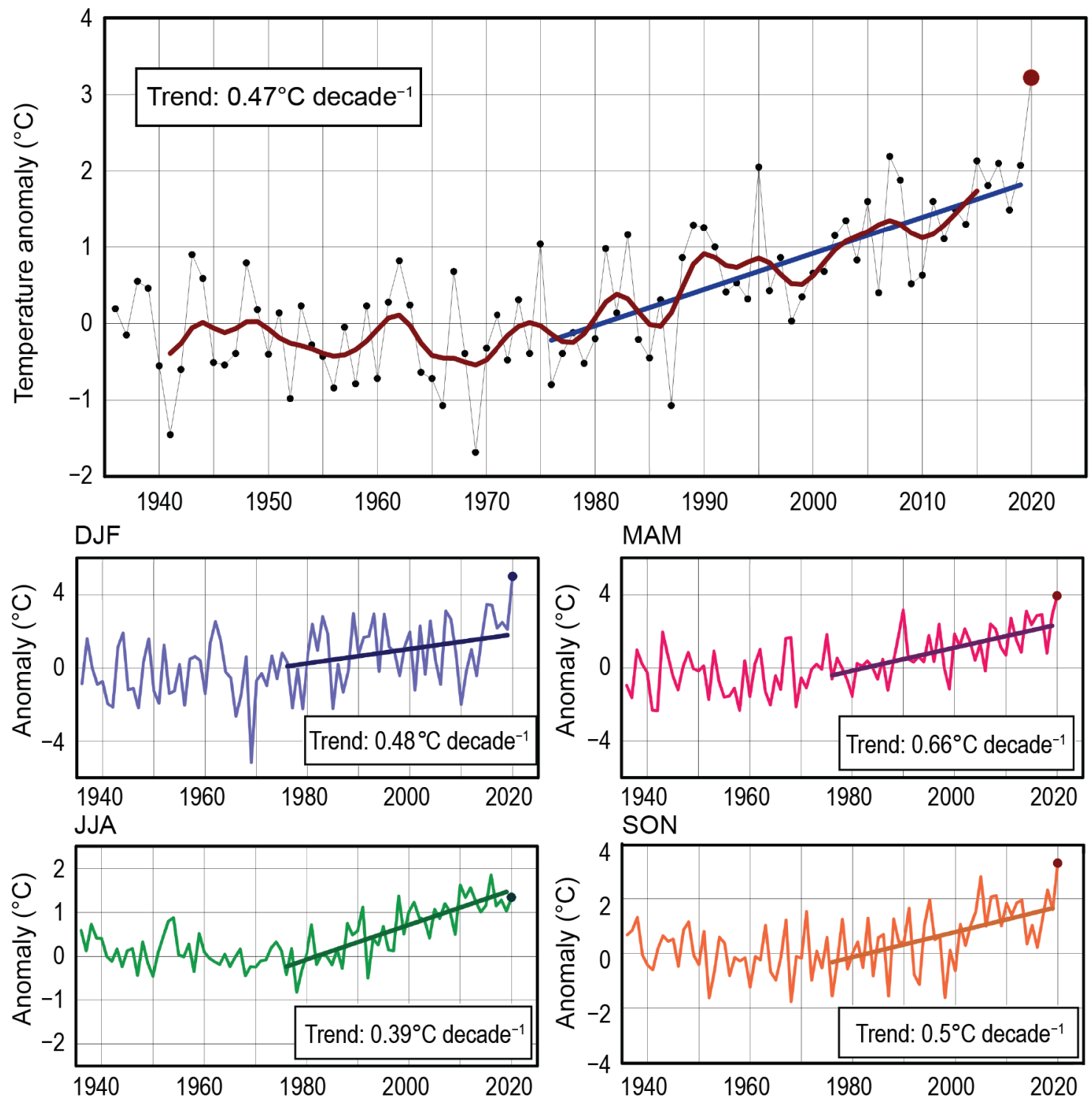

Fig. 7.46. Annual and seasonal mean temperature anomalies $\left({ }^{\circ} \mathrm{C} ; 1961-90\right.$ base period) averaged over the territory of Russia for the period 1936-2020. The bold red line on the annual mean time series is an 11-point binomial filter. Linear trend $\left({ }^{\circ} \mathrm{C}\right.$ decade $\left.{ }^{-1}\right)$ is calculated for the period 1976-2020. 
was the warmest on record with an average temperature $5.9^{\circ} \mathrm{C}$ above normal. It was also very warm in Western Siberia, especially around the Ob’ River estuary, where monthly temperatures were more than $8^{\circ} \mathrm{C}$ above normal.

Summer was the fifth warmest on record, with an overall temperature $1.34^{\circ} \mathrm{C}$ above normal. It was Asian Russia’s seventh-warmest summer, also $1.34^{\circ} \mathrm{C}$ above normal. European Russia observed its 13 th warmest, at $+1.35^{\circ} \mathrm{C}$. The highest departures from average occurred in the polar

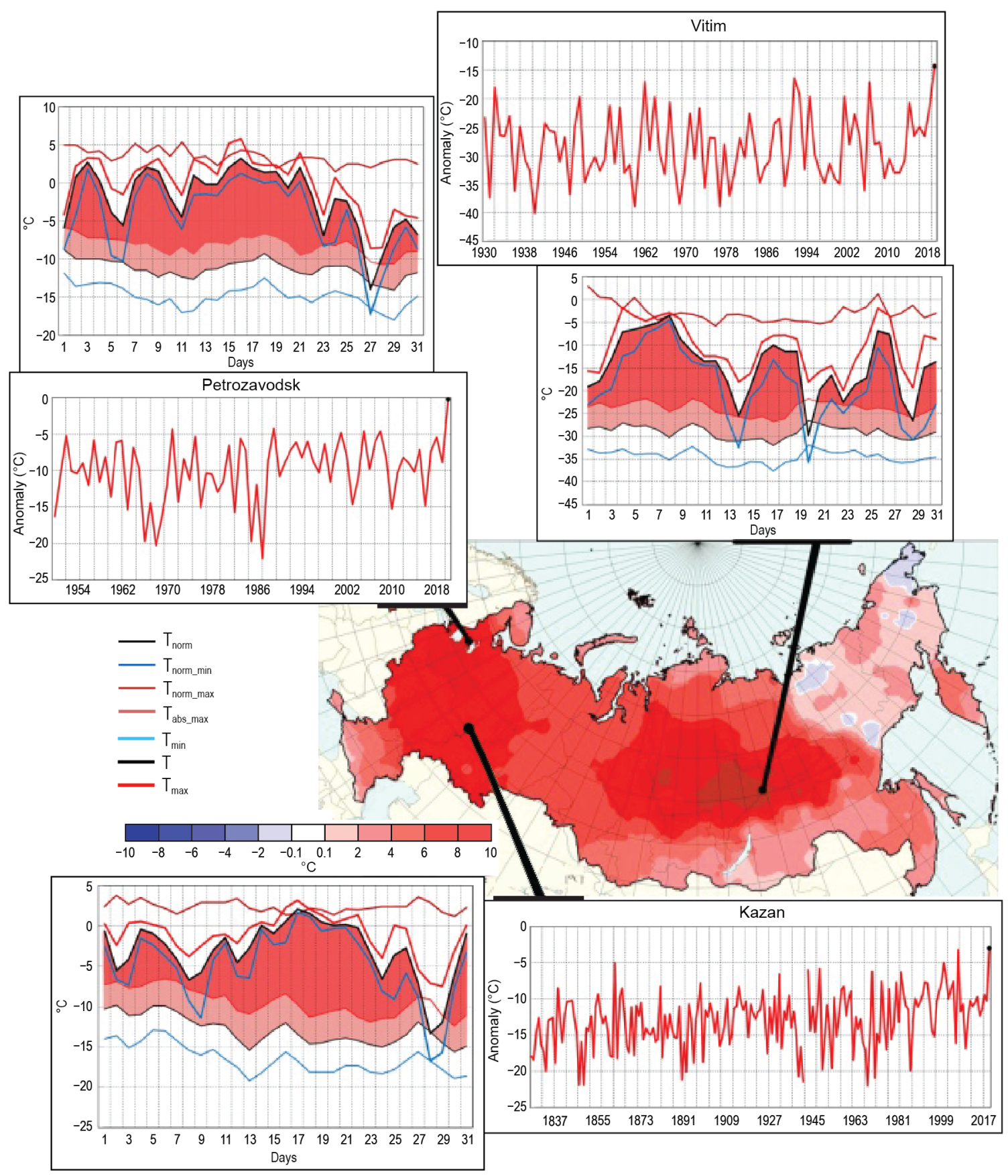

Fig. 7.47. Temperature anomalies across Russia (shading, contour interval is $2^{\circ} \mathrm{C}$ ) in Jan 2020 . Insets: Mean monthly and mean, minimum, and maximum daily temperatures $\left({ }^{\circ} \mathrm{C}\right)$ in Jan 2020 at meteorological stations Petrozavodsk (upper left), Vitim (upper right), and Kazan (bottom). $T_{61-90}$ on plots of monthly temperatures is 1961-90 mean. Plots of daily temperature show observed daily mean ( $T$, black line), daily minimum (Tmin, blue line), and daily maximum (Tmax, red line) temperatures along with their climatological values (three lowermost curves: Tnorm, black; Tnorm_min, blue; Tnorm_max, red) and absolute maximum temperature (Tabs_max, dark red); the area between the normal daily mean curve Tnorm and the observed daily mean curve is shaded pink where $\mathrm{T}>\mathrm{Tnorm}$, and is shaded red if $\mathrm{T}$ was above normal daily maximum Tnorm_max. Starting years of records vary. 
zone of Siberia (temperature anomalies of about $+5^{\circ} \mathrm{C}$ observed at the Kara coast). July had the highest departure from average among the summer months and was the fifth-warmest July on record, at $1.46^{\circ} \mathrm{C}$ above normal.

Autumn in Russia was record warm, $3.29^{\circ} \mathrm{C}$ above average, due to record warmth in September and November $\left(2.49^{\circ} \mathrm{C}\right.$ and $5.44^{\circ} \mathrm{C}$ above normal, respectively) in Asian Russia and in October in European Russia $\left(3.42^{\circ} \mathrm{C}\right.$ above normal). In the second half of November, warm air transported by Atlantic cyclones resulted in the formation of a vast warm area in northern and central Siberia, with temperatures $10^{\circ}-12^{\circ} \mathrm{C}$ above normal.

All seasons in Russia have warmed since the mid-1970s. Annual and seasonal trends are statistically significant at $1 \%$, except winter. Winters cooled after the mid-1990s, then began to warm again after 2010 (Fig. 7.46). The anomalously warm seasons of 2020 resulted in changes of trend estimates, notably winter and autumn estimates for $1976-2020$ are $+0.48^{\circ} \mathrm{C}$ and $+0.50^{\circ} \mathrm{C}$ decade ${ }^{-1}$, respectively, while $1976-2019$ estimates are $+0.39^{\circ} \mathrm{C}$ and $+0.43^{\circ} \mathrm{C}$ decade $^{-1}$.

\section{(II) PRECIPITATION}

Across Russia as a whole, 2020 was among its 15 wettest years on record, with total precipitation about $106 \%$ of normal (Fig. 7.48). Asian Russia was sixth wettest (109\% of normal), while European Russia was near normal (101\%). Overall, winter and spring were wet while summer and autumn were near normal. Southern European Russia experienced precipitation deficits throughout the year, notably in summer and autumn.

Across all of Russia, winter 2019/20 was the third wettest on record, with $120 \%$ of normal precipitation. Asian Russia received $119 \%$ of its normal precipitation (fourth wettest on record), while European Russia received $120 \%$ (tied as eighth wettest). Precipitation above $120 \%$ of normal was observed in Western Siberia and southern Yakutia (Sakha). In northern Eu-

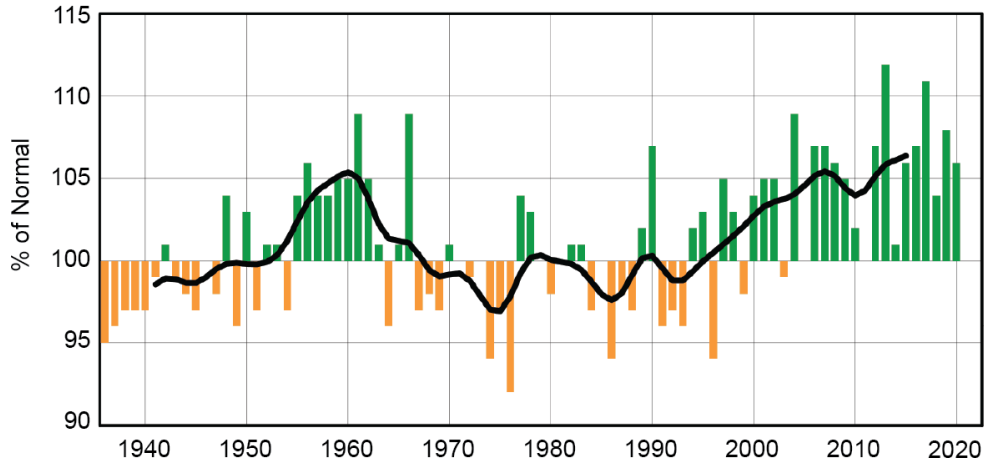

Fig. 7.48. Annual precipitation (\% of normal; 1961-90 base period) averaged over the Russian territory for 1936-2020. The smoothed time series (11-point binomial filter) is shown as a bold line. ropean Russia, the Northwestern Federal District precipitation was record high at $149 \%$ of normal.

It was Russia's fourth-wettest spring on record, with precipitation 121\% of normal; Asian Russia had $119 \%$ of normal precipitation (tied for third wettest), while precipitation in European Russia was 123\% of normal (tied for seventh wettest). The wettest regions were central European Russia (144\%, third wettest on record) and the Urals Federal District (152\%, record wettest). It was the second-wettest March in Asian Russia (169\% of normal), notably wet in central parts of Siberia, Chukotka, and Kamchatka with precipitation above $200 \%$ of normal and above $300 \%-400 \%$ at many stations. April was dry in Asian Russia east of $80^{\circ} \mathrm{E}$ (below $40 \%$ of normal over large areas) and southern European Russia. May was the second wettest on record for the month for Russia as a whole, at $129 \%$ of normal.

In summer, precipitation was less than $70 \%$ of normal in many regions, including southern European Russia, Yakutia (Sakha), and Chukotka. August was dry across Asian Russia east of $80^{\circ} \mathrm{E}$ (with the exception of the narrow belt along the southern boundary).

Autumn was dry over large areas in Siberia and in the central and southern regions of European Russia: $54 \%$ of normal precipitation in the Southern Federal District, marking its third driest autumn on record. Northern European Russia, Baikal, and Amur had a wetter-than-normal autumn. 


\section{(III) NOTABLE EVENTS AND IMPACTS}

On 4 February, heavy rainfall caused flooding on the Pshish River ( $0.2 \mathrm{~m}$ above hazardous level) in the town of Khadyzhensk in the Krasnodar Territory. Flooding inundated and washed out roads, damaged 80 buildings, 22 households, and two pedestrian bridges.

On 13 March, strong winds, as high as $26 \mathrm{~m} \mathrm{~s}^{-1}$, caused substantial damage to infrastructure in Moscow and the Moscow Region. Eleven people were injured and one person was killed.

On 28-30 March, a heavy snowstorm with wind speeds reaching $30-33 \mathrm{~m} \mathrm{~s}^{-1}$ raged for 18 hours in the Pevek settlement, Chukotka Autonomous District. Wind gusts at the coast attained 44-50 $\mathrm{m} \mathrm{s}^{-1}$.

During 24 April-16 July, 333 and 731 fire incidents were recorded in Buryatia and the Trans-Baikal Territory, covering 54,663 and 298,393 ha, respectively.

On 27 June, strong winds up to $24-28 \mathrm{~m} \mathrm{~s}^{-1}$ in the Nizhniy Novgorod Region caused power to be cut off in 92 settlements and also damaged roofs and cars.

On $28 \mathrm{July}, 48 \mathrm{~mm}$ of rain in Moscow inundated underground stations and roads and injured two people.

On 16-17 September, during flooding on the Amur River due to heavy rainfall, the water level around the Leninskoe settlement in the Jewish Autonomous Region rose to $9.68 \mathrm{~m}$, above the danger level of $8.50 \mathrm{~m}$. Two settlements, Leninskoe and Kukelevo, were inundated; 97 people were evacuated.

On 29-30 September, the rainfall flood crest on the Amur River reached the city of Komsomolsk; the water level was $7.04 \mathrm{~m}$, surpassing the danger level of $6.5 \mathrm{~m}$. Basements in four kindergartens, the city theatre, and 50 high rise buildings were inundated, with water levels more than $1 \mathrm{~m}$ in places.

3) East and Southeast Asia-P. Zhang, T. C. Lee, S. Supari, M. Hanafusa, Hir. Sato, S. Wakamatsu, G. S. Im,

D. Dulamsuren, A. Moise, M-V. Khiem, and H-P. Lam

Countries/places considered in this section include China, Hong Kong (China), Indonesia, Japan, Korea, Mongolia, Singapore, and Vietnam. Unless otherwise noted, anomalies refer to a normal period of 1981-2010.

\section{(I) TEMPERATURE}

Annual mean temperatures for 2020 across East and Southeast Asia are shown in Fig. 7.41. The annual mean air temperature for China was $0.7^{\circ} \mathrm{C}$ above the $1981-2010$ normal, the eighth highest since the start of the record in 1951. Temperatures were above normal in all seasons, especially winter (December 2019 -February $\left.2020 ;+1.2^{\circ} \mathrm{C}\right)$ and spring $\left(+1.1^{\circ} \mathrm{C}\right)$. Hong Kong, China, experienced its second-warmest year on record since 1884, with an annual mean temperature of $24.4^{\circ} \mathrm{C}, 1.1^{\circ} \mathrm{C}$ above normal.

Annual mean temperatures were significantly above normal across Japan. Eastern Japan's annual temperature anomaly was $+1.2^{\circ} \mathrm{C}$, the highest since records began in 1946 . South Korea's annual mean temperature was $13.2^{\circ} \mathrm{C}\left(+0.7^{\circ} \mathrm{C}\right.$ above average; fifth highest since national records began in 1973). In January and June, the monthly mean temperatures were $2.8^{\circ} \mathrm{C}\left(+3.8^{\circ} \mathrm{C}\right.$ above normal) and $22.8^{\circ} \mathrm{C}\left(+1.6^{\circ} \mathrm{C}\right.$ above normal), respectively, which were record high for those months. The annual mean temperature over Mongolia was $1.1^{\circ} \mathrm{C}\left(+1.0^{\circ} \mathrm{C}\right.$; sixth highest since 1940); the country observed its third-warmest April on record with an average temperature $3.3^{\circ} \mathrm{C}$ above normal in the range of $0.1^{\circ}$ to $5.1^{\circ} \mathrm{C}$. Mongolia experienced its greatest negative monthly anomaly of the year in December, $-3.0^{\circ} \mathrm{C}$ below normal (mean temperature of $-21.2^{\circ} \mathrm{C}$ ).

At $+0.94^{\circ} \mathrm{C}$, the annual mean temperature for Indonesia was second highest since the start of the record in 1981 (behind 2016). Only two out of the 83 reporting stations observed negative temperature anomalies. The highest temperature recorded during the year was $38.4^{\circ} \mathrm{C}$ on 4 November in East Nusa Tenggara. Singapore's annual mean temperature in 2020 was $28.0^{\circ} \mathrm{C}\left(+0.5^{\circ} \mathrm{C}\right.$ above 
normal; eighth highest on record). Four of the past 6 years are among the country's 10 warmest years since 1929, when records began. Above-average monthly temperatures were recorded for the first five months of 2020 , peaking in May at $28.9^{\circ} \mathrm{C}$. June 2020 was the second-coolest June in the past 20 years $\left(28.1^{\circ} \mathrm{C}\right.$; $-0.2^{\circ} \mathrm{C}$ below average). September 2020 tied the record with 2013 for the coolest September in the last 10 years $\left(27.5^{\circ} \mathrm{C} ;-0.1^{\circ}\right.$ below average).

There were 13 large-scale heat waves in Vietnam during 2020. In June, the daily maximum temperature exceeded $35^{\circ} \mathrm{C}$ in most parts of the country, with an average monthly temperature $+1.5^{\circ}$ to $+2.5^{\circ} \mathrm{C}$ above average. In the Northern Delta and North Central regions, the monthly temperature anomalies reached approximately $+3^{\circ} \mathrm{C}$ : Hanoi $\left(+3.0^{\circ} \mathrm{C}\right)$, Bac Ninh $\left(+3.0^{\circ} \mathrm{C}\right)$, Ha Nam $\left(+2.9^{\circ} \mathrm{C}\right)$, and Hung Yen $\left(+2.8^{\circ} \mathrm{C}\right)$.

\section{(II) PRECIPITATION}

Figure 7.42 shows the 2020 annual precipitation as a percentage of normal over East and Southeast Asia. The annual mean precipitation total for China was $694.8 \mathrm{~mm}, 110.3 \%$ of normal and the fourth highest since 1951. The annual total precipitation for river basins was above normal in the Songhua River (138\%), Huaihe River (124\%) Yangtze River (122\%, highest since start of record in 1961), Yellow River (116\%), Liaohe River (112\%), and Haihe River (112\%), and below average in the Pearl River (95\%). In 2020, the annual total rainfall of Hong Kong, China, was 2395.0 mm, near the average of $2398.5 \mathrm{~mm}$.

In Japan, annual precipitation amounts were significantly above average on the Sea of Japan side of western Japan and above average on the Sea of Japan side of northern Japan, on the Pacific side of eastern and western Japan, and in Okinawa/Amami. Annual total precipitation in South Korea was $1591.2 \mathrm{~mm}$ (121.7\% of normal; sixth wettest since national records began in 1973). From June to August, South Korea received its third-highest precipitation total on record for June-August (1007.0 mm). Although Mongolia's annual total precipitation was near normal at $251.3 \mathrm{~mm}$, April 2020 was the driest April since 1940 at $32.4 \%$ of normal.

In Indonesia, annual rainfall was generally above normal with 23 of 83 weather stations recording more than $120 \%$ of normal precipitation, likely associated with the development of the 2020/21 La Niña event. The spatial average of 2713 mm makes 2020 the third-wettest year since the start of the record in 1981, behind 2010 and 1998, both of which were strong La Niña years. The largest rainfall anomaly, approximately $209 \%$ of normal, was recorded in Kerinci, Sumatra. In Singapore, annual total rainfall was near average over most of the island-wide rainfall stations. However, the Changi climate station recorded its eighth-lowest annual total rainfall over the past 30 years (1886.6 mm; 87\% of normal). The driest period in 2020 was January-March, with less than $70 \%$ of average precipitation observed during each month. In contrast, the 2020 Southwest Monsoon season (June-September) was the wettest since 1981 (30\% above normal), coinciding with the emergence of La Niña. Singapore also experienced 6 days with rainfall rates above $70 \mathrm{~mm} \mathrm{hr}^{-1}$ (the highest recorded since 2013).

In Vietnam, there was a prolonged heavy rainfall period during October and the first half of November with total rainfall of 1000+ mm in many places, including: Ha Tinh City (Ha Tinh): 2521 mm; Khe Sanh (Quang Tri): 2894 mm; A Luoi (Thua Thien Hue): 4526 mm; Tra My (Quang Nam): $2813 \mathrm{~mm}$; and Ba To (Quang Ngai): $2292 \mathrm{~mm}$. The daily rainfall amounts were exceptionally high in Huong Linh (Quang Tri): $763 \mathrm{~mm} \mathrm{day}^{-1}$; Thuong Nhat (Thua Thien Hue): $719 \mathrm{~mm}$ day $^{-1}$; Ky Thuong (Ha Tinh): 809 mm day ${ }^{-1}$; and Ha Tinh city (Ha Tinh): 884 mm day ${ }^{-1}$.

\section{(III) NOTABLE EVENTS AND IMPACTS}

In China, typhoon-related disaster damage in 2020 was significantly less than that of the past 10 years (2010-19), with eight people dead or missing and approximately $\$ 4.7$ billion (U.S. dollars) in direct economic losses. During March-April, drought occurred in the southwestern province of Yunnan due to both below-average precipitation $(20 \%-50 \%$ of normal over most of 
the region) and above-average temperatures $\left(+1^{\circ}\right.$ to $\left.+2^{\circ} \mathrm{C}\right)$. In mid-April, an area encompassing $195,000 \mathrm{~km}^{2}$ was classified in the middle category and higher, according to the meteorological drought composite index. Conversely, the Meiyu/Baiu/Changma season, which started earlier and ended later than normal, was the wettest such season since 1961 (see Sidebar 7.2 for a discussion of this event). During summer 2020, the Yangtze River basin experienced its most severe flooding since 1998, due to heavy rain.

Hong Kong, China, experienced its hottest summer (June-August) on record with a mean temperature of $29.6^{\circ} \mathrm{C}\left(1.2^{\circ} \mathrm{C}\right.$ above normal). With a record-breaking mean temperature of $30.2^{\circ} \mathrm{C}$, July 2020 was the hottest of any month in Hong Kong, China, since records began in 1884. Hong Kong, China, reported 50 Hot Nights (daily minimum temperature $\geq 28.0^{\circ} \mathrm{C}$ ) and 47 Very Hot Days (daily maximum temperature $\geq 33.0^{\circ} \mathrm{C}$ ) in 2020 , with both breaking the highest annual record. Packing high winds and heavy rain, the strike of Typhoon Higos to the Pearl River Estuary necessitated the issuance of the Increasing Gale or Storm Signal No. 9 in Hong Kong, China, on 19 August.

In July, long-term heavy rain events occurred mainly in eastern and western Japan due to the active Baiu front. As a result, there was record heavy rainfall and lack of sunshine in these regions. The end of rainy season was later than normal nationwide, except in the Okinawa region.

South Korea experienced its second-highest total precipitation (693.4 mm) since 1973 during Changma, the monsoon season. In early September, Typhoon Maysak made landfall in the southeastern part of South Korea, and record high precipitation of $1037.5 \mathrm{~mm}$ was observed at Mt. Halla on Jeju island from 2 to 3 September.

In Mongolia, a total of 90 hydrometeorological extreme events were reported during 2020. During the summer, convection-related extreme events such as flood, hail, and lightning occurred more often than usual, with lightning frequency setting a record for the year. Together, these extreme events caused 15 fatalities and about \$2.7 million (U.S. dollars) in economic losses.

On 1 January, Jakarta, Indonesia, experienced extremely heavy rainfall, with daily rainfall totals of more than $200 \mathrm{~mm}$ at many observation points. The highest total was $377 \mathrm{~mm}$, recorded at Halim Airport in southeastern Jakarta. This marked the highest daily rainfall in Jakarta since 1996. The extreme precipitation triggered floods that affected large areas of this capital city and disrupted public transportation.

In Singapore, intense heavy rainfall events occurred more frequently in 2020, with total hourly rainfall exceeding $70 \mathrm{~mm}$ on 6 days (the top $1 \%$ of all heavy rainfall events recorded in Singapore), causing flash floods at various locations across the island. The highest hourly rainfall total of 2020 was $106.1 \mathrm{~mm}$ recorded in August at Bedok South; the record high hourly rainfall total of $130.7 \mathrm{~mm}$ was recorded at Ulu Pandan in July 2007.

Of 15 tropical cyclones that occurred in the South China Sea in 2020, eight directly affected Vietnam. Typhoon Molave was one of the most intense storms to reach Vietnam in the past 20 years. Binh Chau (Quang Ngai) recorded average wind speeds of $34 \mathrm{~m} \mathrm{~s}^{-1}$ and gusts of $42 \mathrm{~m} \mathrm{~s}^{-1}$. Ly Son stations (Quang Ngai) observed average wind speeds of $31 \mathrm{~m} \mathrm{~s}^{-1}$ and gusts of $41 \mathrm{~m} \mathrm{~s}^{-1}$. 
Exceptionally strong and prolonged precipitation occurred along the Meiyu/Baiu/Changma front, extending from central China to southern Japan, in June-July 2020 (Fig. SB7.3a). The accumulated rainfall total over the Yangtze River Valley (YRV) during that 2-month period was the largest for the past 60 years. Historically, floods have occurred over the YRV and along the Meiyu/ Baiu/Changma front during the decaying phase of a strong eastern Pacific (EP) El Niño (e.g., in 1983, 1998, and 2016; Chang et al. 2000a,b; Li and Wang 2005). Summer 2020 was preceded only by a moderate central Pacific (CP) El Niño (termed by China Meteorological Administration). What caused the exceptionally strong flood?

The most notable feature of the anomalous circulation in June-July (J) 2020 is a large-scale, low-level anticyclone in the tropical western North Pacific (WNP) south of the Meiyu/Baiu/ Changma front (Fig. SB7.3a). Southerly anomalies west of the anticyclone advected warm and moist air northward, converging into the front. The occurrence of the low-level anomalous anticyclone signifies a southwestward shift of the Western Pacific Subtropical High.

During the prolonged period of heavy rainfall, the upper-tropospheric circulation anomaly was characterized by a quasi-stationary Rossby wave train pattern (Fig. SB7.3b) elongated along the subtropical jet stream in Eurasia. The Rossby wave train is known as the Silk Road teleconnection pattern (Enomoto et al. 2003).

Another notable feature is a cold surface temperature anomaly north of the Meiyu front (Fig. SB7.4c). The cold anomaly resulted from cold advection by northeasterly anomalies in northeastern Asia (Fig. SB7.4a). A dipole pattern appeared in the anomalous temperature advection field. This dipole pattern strengthened the meridional temperature gradient and led to a persistent and strong front.

A similar dipole pattern appeared in the anomalous moisture advection field, as seen in Fig. SB7.4b. As a result, abnormally dry air appeared north of the Meiyu/Baiu/Changma front, while the moisture increased along the front. A remarkable north-south contrast between a dry/cold condition to the
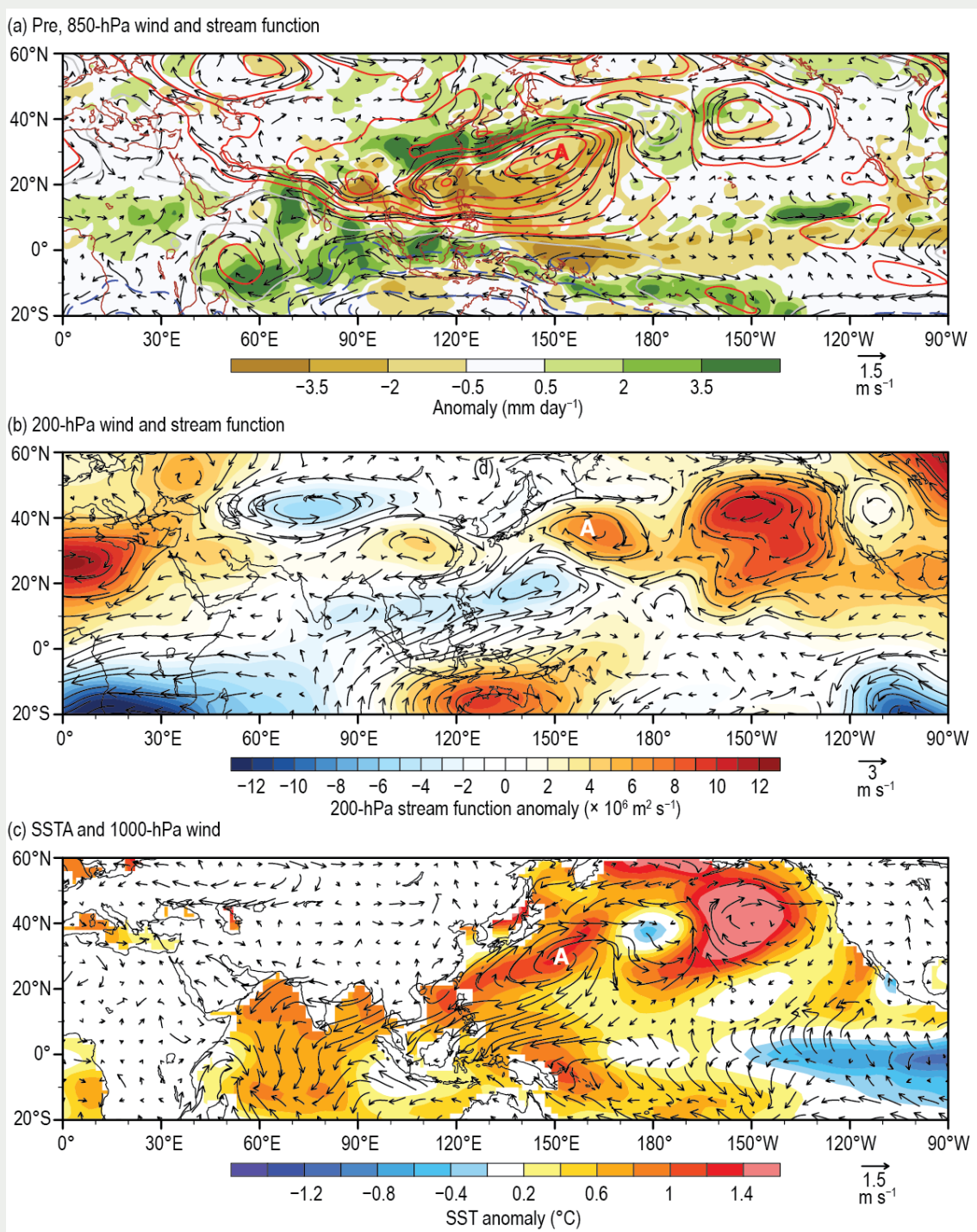

Fig. SB7.3. The horizontal patterns of (a) anomalous precipitation (shading, $\mathrm{mm}$ day $^{-1}$ ) and wind (vector, $\mathrm{ms}^{-1}$ ) and stream function (contour $10^{6} \mathrm{~m}^{2} \mathrm{~s}^{-1}$ ) anomalies at $850 \mathrm{hPa}$, (b) anomalous wind (vector, $\mathrm{ms}^{-1}$ ) and stream function (contour $10^{6} \mathrm{~m}^{2} \mathrm{~s}^{-1}$ ) at $200 \mathrm{hPa}$, and (c) anomalous SST (shading, ${ }^{\circ} \mathrm{C}$ ) and wind at $1000 \mathrm{hPa}$ (vector, $\mathrm{ms}^{-1}$ ) averaged in Jun-Jul (J) 2020. The baseline for the mean climatology is 1979-2020. Letter " $A$ " denotes the anomalous anticyclonic center in the WNP.

north and a wet/warm condition to the south can be clearly seen in the low-level moist static energy (MSE) anomaly field (Fig. SB7.4d). A positive MSE anomaly appeared south of $30^{\circ} \mathrm{N}$ in East Asia, whereas a negative MSE anomaly occurred north of $30^{\circ} \mathrm{N}$. The separation line was tilted slightly toward the northeast. The placement of the high MSE air to the south and the low MSE air to the north persisted for the 2-month period, leading to a stationary Meiyu/Baiu/Changma front (Fig. SB7.3a). 
Typically, the Meiyu rainband remains over the YRV for a relatively short period ( 2-3 weeks) and then moves northward. Why did the anomalous circulation and rainband persist. Why did the anomalous circulation and rainband persist for a 2-month period during JJ 2020? Given that the atmospheric circulation does not have such a long memory, it is important to examine the oceanic forcing (Wang et al. 2003). As seen in Fig. SB7.3c, a La Niña-like sea surface temperature anomaly (SSTA) pattern appeared in the equatorial Pacific in June-July (JJ) 2020. Meanwhile, a warm SSTA occurred over the tropical Indian Ocean (IO).

Idealized numerical model (ECHAM4) experiments confirmed the roles of the La Niña-like SSTA pattern in the Pacific and the warming in the 10 in maintaining the WNP anticyclone in JJ 2020. Typically, a CP El Niño is characterized by a slow SSTA transition in the equatorial Pacific (Li and Hsu 2017); however, the 2019/20 CP El Niño was an exception. A quick phase transition occurred in early 2020, and by $\mathrm{JJ}$ a cold SSTA appeared in the equatorial Pacific. The cold SSTA induced a negative precipitation anomaly in the equatorial $\mathrm{CP}$, leading to an anomalous anticyclone response to its northwest (Gill 1980).

A moderate warming in the tropical 10 is often observed during the decaying phase of a CP El Niño. The exceptionally strong 10 warming in JJ 2020 was attributed to the combination of the interannual variation and the interdecadal fluctuation/long-term trend. The strong 10 warming induced a Kelvin wave response to its east and maintained the WNP anticyclone through the Kelvin wave-induced anticyclonic shear mechanism (Wu et al. 2009; Li et al. 2017).
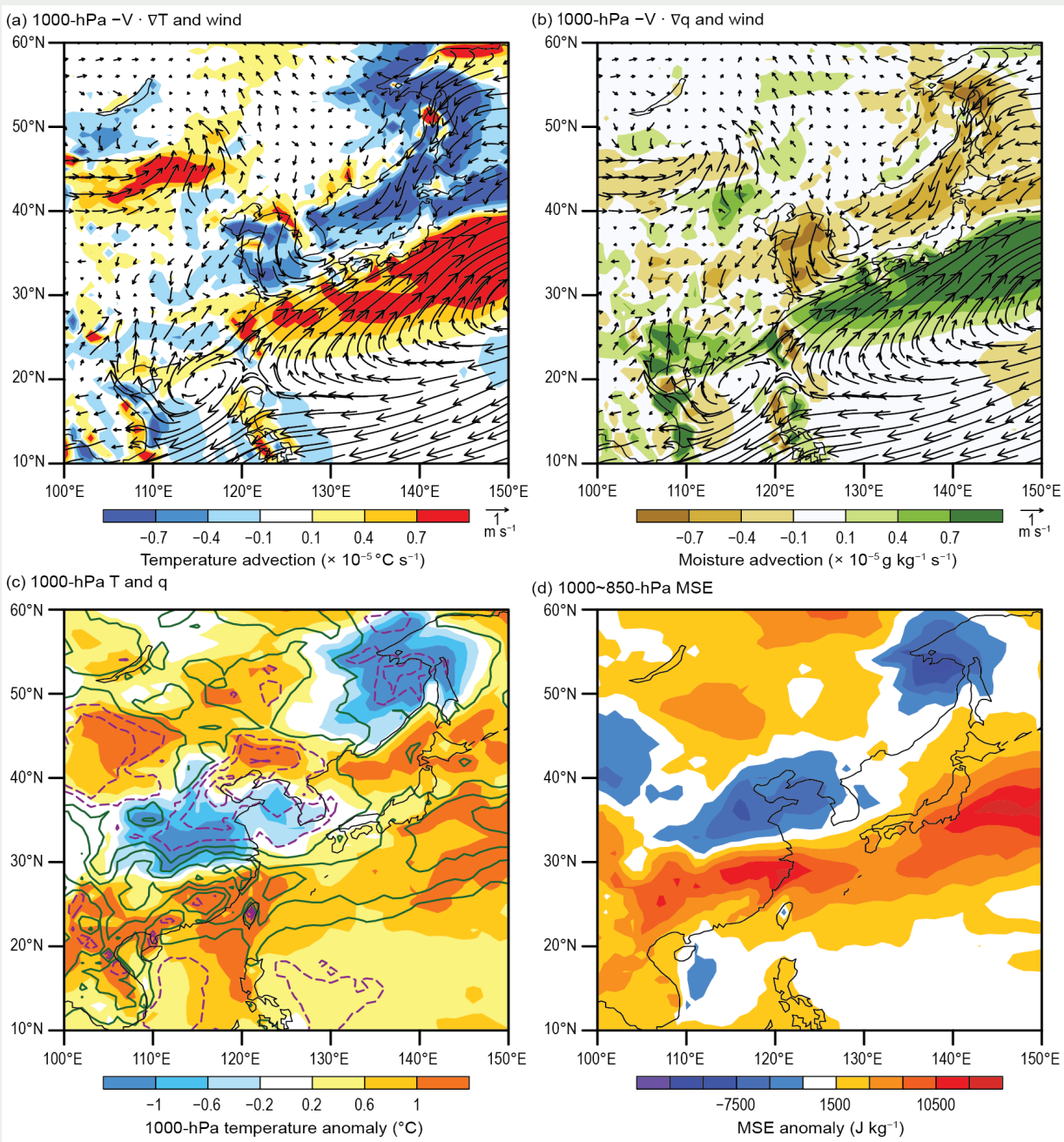

(d) 1000 850-hPa MSE

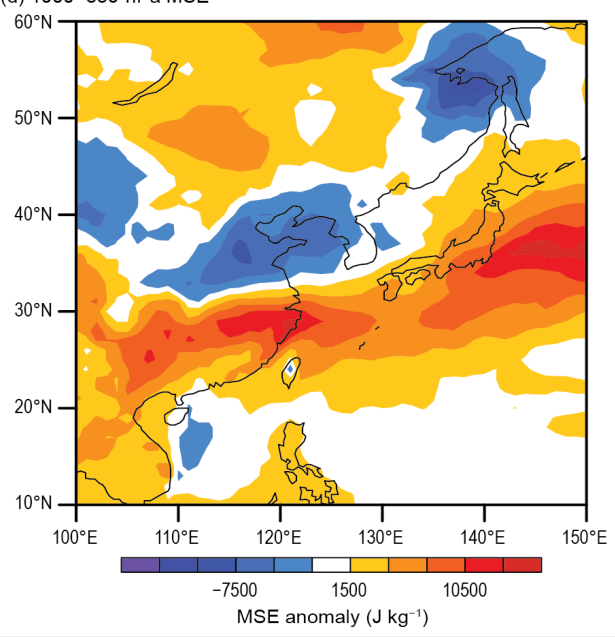

Fig. SB7.4 The horizontal patterns of (a) advection of mean temperature by anomalous wind at $1000 \mathrm{hPa}$ (shading, $\times 10^{-5}{ }^{\circ} \mathrm{C} \mathrm{s}^{-1}$ ) superposed by $1000-\mathrm{hPa}$ wind anomaly vector $\left(\mathrm{m} \mathrm{s}^{-1}\right)$, (b) advection of mean moisture by anomalous wind (shading, $\times 10^{-5} \mathrm{~g} \mathrm{~kg}^{-1} \mathrm{~s}^{-1}$ ) superposed by the anomalous wind vector at $1000 \mathrm{hPa}\left(\mathrm{m} \mathrm{s}^{-1}\right),(\mathrm{c})$ anomalous temperature (shading, ${ }^{\circ} \mathrm{C}$ ) and specific humidity (contour, $\mathrm{g} \mathrm{kg}^{-1}$ ) at $1000 \mathrm{hPa}$, and (d) moist static energy (shading, $\mathrm{J} \mathrm{kg}^{-1}$ ) anomaly integrated from $1000 \mathrm{hPa}$ to $850 \mathrm{hPa}$ averaged in JJ 2020.
The observational analysis above reminds us that caution is needed in predicting El Niño impacts based on composite results alone. A more detailed tracking of the SSTA evolution, such as a slow or quick phase transition, is critical. One needs also to consider the impact of the interdecadal change and long-term warming trend. Finally, it is important to consider that there is always inherent variability in the climate system that can influence atmospheric circulation patterns in any given year and thus alter expected ENSO impacts in a variety of ways. 
4) South Asia-0. P. Sreejith, A. K. Srivastava, and M. Rajeevan

Countries in this section include Bangladesh, India, Pakistan, and Sri Lanka. Unless otherwise noted, climate anomalies are relative to the 1981-2010 base period.

\section{(I) TEMPERATURE}

In 2020, South Asia generally experienced above-normal temperatures. The annual mean temperature averaged over India was $0.29^{\circ} \mathrm{C}$ above the $1981-2010$ average, making 2020 the eighth-warmest year since nationwide records began in 1901 (Fig. 7.49). India's average seasonal mean temperatures were above normal for all of the seasons except the pre-monsoon season (March-May), when it was slightly below normal. India's average seasonal mean temperature anomalies during the monsoon season (June-September, $+0.43^{\circ} \mathrm{C}$ ) and the post-monsoon season (October-December, $+0.53^{\circ} \mathrm{C}$ ) largely accounted for the above-normal annual temperature for the year. The warmest year on record is $2016\left(0.71^{\circ} \mathrm{C}\right.$ above average).

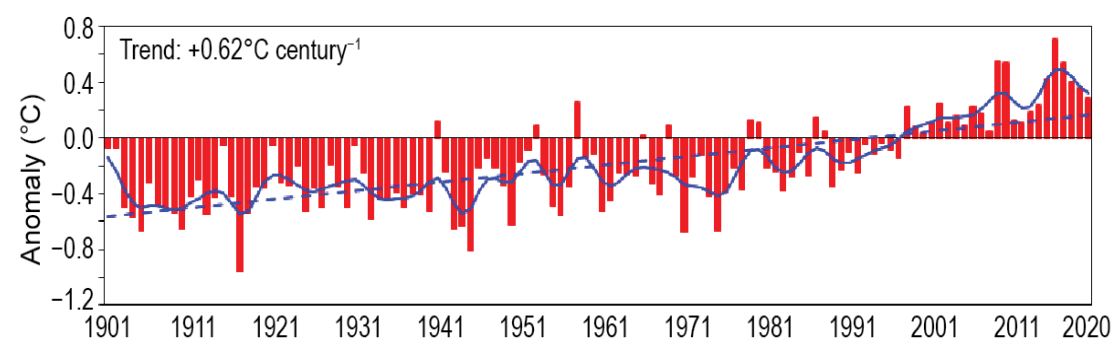

Fig. 7.49. Annual mean temperature anomalies $\left({ }^{\circ} \mathrm{C} ; 1981-2010\right.$ base period) averaged over India for the period 1901-2020. The smoothed time series (9-point binomial filter) is shown as a continuous blue curve.

\section{(II) PRECIPITATION}

The summer monsoon season (June-September) contributes about $75 \%$ of the annual precipitation over South Asia. The 2020 summer monsoon season set in over Kerala (southwestern parts of peninsular India) on its climatological normal date (1 June) and covered the entire country on 26 June, 12 days ahead of its normal date.

For India, the Long Term Average (LTA) value of the summer monsoon rainfall, calculated using all data from 1961 to 2010, is $880 \mathrm{~mm}$. The standard deviation of Indian summer monsoon rainfall (ISMR) is around 10\% of the LTA; however, over smaller regions, the natural variability of the monsoon (standard deviation) is large-around 19\%. As such, the ISMR exceeding 110\% of the LTA in a year is considered excess rainfall, while the ISMR less than $90 \%$ of the LTA in a year is considered deficient rainfall.

During 2020, the ISMR averaged over the country as a whole was 109\% of its LTA value, high but within the normal range. In general, rainfall was fairly well distributed over most parts of the country. The seasonal rainfall over the homogeneous regions of Northwest India, Central India, South Peninsula, and East/Northeast India was 84\%, 115\%, 129\%, and 106\% of their LTA, respectively. The homogeneous region of Northwest India received comparatively less rainfall (84\% of LTA; Fig. 7.50). At the monthly scale, rainfall for the country as a whole was above normal during June and August (118\% and 127\% of LTA, respectively) and normal during July and September (90\% and $104 \%$ of LTA, respectively). For the country as a whole, average rainfall was above or near normal on most of the days during the season (Fig. 7.51). Table 7.2 lists 24-hour rainfall records during the 2020 ISMR season.

During winter (January-February) 2020, rainfall over India was normal (99\% of LTA). It was above normal (121\% of LTA) during the pre-monsoon season (March-May), while during the postmonsoon season (October-December), it was normal (101\% of LTA).

Pakistan, located at the western edge of the pluvial region of the South Asian monsoon, receives $60 \%-70 \%$ of its annual rainfall during its summer monsoon season (July-September). The climatological summer monsoon sets over eastern parts of Pakistan around 1 July with a standard deviation of 5 days; in 2020 onset occurred on 26 June. The summer monsoon rainfall over Pakistan for the season was above normal (141\% of LTA). Rainfall was below normal in July (66\% of LTA), 
normal during August (108\%), and significantly above normal during September (189\%). Spatially, rainfall was generally above normal over most of the country except some parts of the west central and northwestern regions. Sindh and Baluchistan provinces received exceptionally high rainfall during the monsoon season ( $463 \%$ and $371 \%$ of their LTA, respectively). During the summer monsoon season in Bangladesh and Sri Lanka (May-September), Bangladesh received normal rainfall and Sri Lanka received above-normal rainfall.

The northeast monsoon (NEM) sets in over southern peninsular India during October and over Sri Lanka in late November. The NEM contributes 30\%-50\% of the annual rainfall over southern peninsular India and Sri Lanka as a whole. In 2020, the NEM set in over southern peninsular India on 28 October. The 2020 NEM seasonal rainfall over south peninsular India was normal (110\% of LTA); NEM rainfall activity over Sri Lanka during October to December 2020 was also normal.

\section{(III) NOTABLE EVENTS AND IMPACTS}

Cold wave conditions prevailed over central parts of India, notably during January, and caused the deaths of about 150 people. Of these deaths, 88 were from the northern Indian state of Uttar Pradesh, 45 from Bihar (all reported on a single day, 1 January), and 16 from the state of Jharkhand.

Heavy rainfall and flood-related incidents claimed more than 600 lives from different parts of India during the pre-monsoon, monsoon, and post-monsoon seasons. On 7 August, in the Munnar and Idukki districts of Kerala, 65 people were killed during landslides triggered by heavy rainfall activity.

Thunderstorms and lightning, along with associated flash floods, hail, and strong winds, claimed 815 lives from different parts of India. Among these, 280 deaths were reported in Bihar, 220 in Uttar Pradesh, 122 in Jharkhand, 72 in Madhya Pradesh, 23 in Maharashtra, and 20 in Andhra Pradesh. Severe thunderstorms and lightning on 26 February and 14 March resulted in approximately 200 deaths in different parts of Uttar Pradesh, Bihar, and Jharkhand (northern/ eastern parts of India).

In Bangladesh, continuous heavy rains from late June through much of July caused one of the most severe floods in decades, affecting one-third of the country. Approximately 50 people died and more than 1.5 million people were affected by this flooding. In addition, there was widespread loss of crops and houses.

Across Pakistan, heavy rains and floods killed about 400 people during the monsoon season. Karachi, the most populous city in Pakistan, received record rainfall during August, mainly due to continuous heavy rains during the last week of the month. On 28 August, one station in Karachi Faisal reported the highest ever recorded 24-hour rainfall: $231.0 \mathrm{~mm}$. With the excess rainfall, Karachi flooded in the last week of August, killing approximately 50 people.

(a) Actual

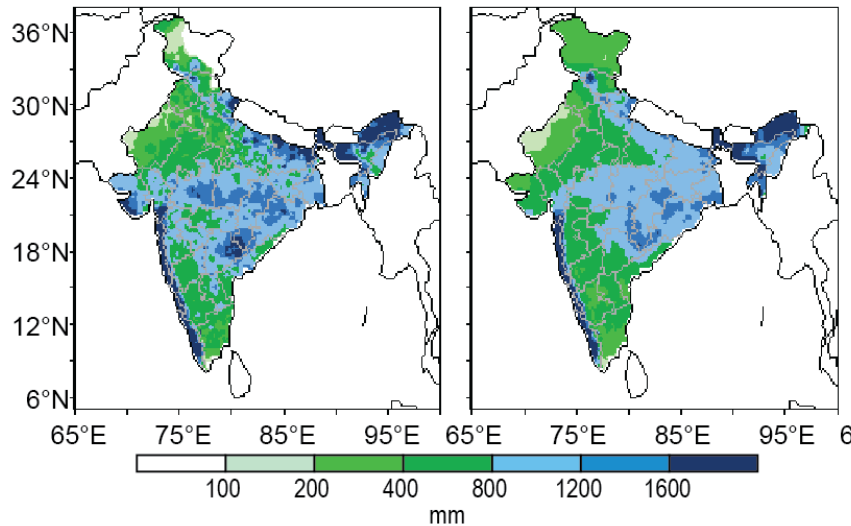

(c) Anomaly



Fig. 7.50. Spatial distribution of (a) actual, (b) normal, and (c) anomalous monsoon seasonal (Jun-Sep) rainfall (mm) over India in 2020. 


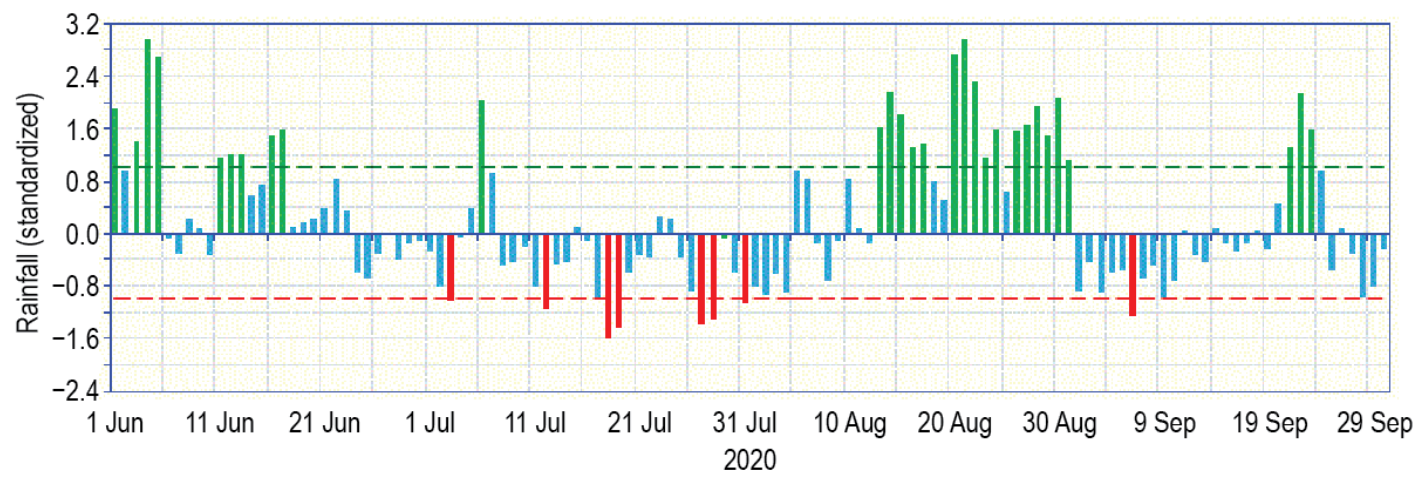

Fig. 7.51. Daily standardized rainfall time series averaged over the core monsoon zone of India (1 Jun-30 Sep 2020). The horizontal dashed lines delineate anomalies greater than \pm 1 std. dev. The green, red, and blue color bars indicate days with active, suppressed, and normal monsoon conditions, respectively.

\begin{tabular}{|c|c|c|c|c|c|}
\hline Station & 24-hour rainfall $(\mathrm{mm})$ & Date & Previous record $(\mathrm{mm})$ & Date of record & Year of record \\
\hline \multicolumn{6}{|c|}{ Jun 2020} \\
\hline Ozar (Nashik AP) & 144.2 & 4 & 103.2 & 27 & 2002 \\
\hline K. Paramathy & 84.0 & 2 & 57.6 & 1 & 2000 \\
\hline \multicolumn{6}{|c|}{ Jul 2020} \\
\hline Okha & 476.7 & 8 & 330.5 & 27 & 2010 \\
\hline Mahbubnagar & 131.6 & 3 & 106.6 & 23 & 2005 \\
\hline Nandyal & 145.8 & 30 & 143.2 & 11 & 2010 \\
\hline Chennai AP & 115.4 & 10 & 85.8 & 16 & 1978 \\
\hline \multicolumn{6}{|c|}{ Aug 2020} \\
\hline Indore & 263.4 & 22 & 212.6 & 10 & 1981 \\
\hline Mumbai (Colaba) & 331.8 & 6 & 287 & 3 & 1881 \\
\hline Dahanu & 383.1 & 5 & 353.3 & 14 & 1945 \\
\hline Hanamkonda & 212.2 & 15 & 190.5 & 26 & 1924 \\
\hline Pamban & 121.8 & 9 & 73.9 & 31 & 1937 \\
\hline \multicolumn{6}{|c|}{ Sep 2020} \\
\hline Mangalore AP & 251.8 & 11 & 159.8 & 24 & 2010 \\
\hline Panambur & 229.6 & 11 & 125.2 & 24 & 2010 \\
\hline Belgaum (Sambra) AP & 168.1 & 10 & 150 & 24 & 2010 \\
\hline
\end{tabular}

In 2020, five tropical cyclones formed over the North Indian Ocean: Super Cyclonic Storm Amphan, Very Severe Cyclonic Storm Nivar, and Cyclonic Storm Burevi developed in the Bay of Bengal, while Severe Cyclonic Storm Nisarga and Very Severe Cyclonic Storm Gati formed over the Arabian Sea. Amphan formed during the pre-monsoon season and crossed the coast of the northeastern Indian state of West Bengal over Sundarbans on 20 May. The storm claimed 90 lives and about 4000 livestock, mainly from West Bengal. Nisarga, which formed early in the monsoon season, crossed the coast of the western Indian state of Maharashtra on 3 June. The remaining three cyclones, Nivar, Burevi, and Gati, formed during the post-monsoon season. Nivar crossed the coast of the south Indian state of Tamil Nadu close to Puducherry, killing 12 people and more than 10,800 livestock from the states of Tamil Nadu and Andhra Pradesh. In Tamil Nadu, Burevi killed nine people and 200 livestock. Additionally, from 1 to 3 December, Burevi brought heavy rainfall to the northern and eastern districts of Sri Lanka, which resulted in severe floods in the region during the first 2 weeks of December. Although more than 90,000 people were affected 
by the flooding, there were few casualties and house collapses. Gati moved westward, making landfall over the Somalia coast. Please refer to section $4 \mathrm{~g} 5$ for more details about the 2020 North Indian Ocean tropical cyclone season.

5) Southwest Asia-A. Vazifeh, A. Fazl-Kazem, H. R. Hasannezhad, P. Asgarzadeh, and S. Tajbakhsh-Mosalman This section covers only Iran. Turkey is included in the Europe subsection, $7 \mathrm{f}$. Climate anomalies are relative to a 1984-2019 base period for temperature and precipitation.

\section{(I) TEMPERATURE}

Generally, Iran experienced above-average mean temperatures (Fig. 7.52) throughout all four seasons, with some areas reporting a seasonal mean temperature that was $+3^{\circ} \mathrm{C}$ above the normal range. For the most part, during spring and autumn, the eastern half of the country was in the normal-to-below normal temperature range; the western half of Iran was in the above-normal temperature range throughout all of 2020.

\section{(II) PRECIPITATION}

In general, spring was wetter than normal in the southeast provinces and central regions, and autumn was wetter than normal in the southwest (Figs. 7.53b,d). In spring, Iran received below-normal precipitation across most of the country except in the south-southeast. The season was relatively dry with below-normal precipitation, and, in particular, the shortage of rainfall in western mountainous regions was considerable (with normal annual range being 450-650 mm).

In summer, rain is generally limited to northern provinces in the southern coastal regions of the Caspian Sea, through migrating summertime midlatitude cyclonic activity and lake effectinduced rain by the Caspian Sea influence, and in southeast Iran through monsoonal activity and westward movement of mid-tropospheric inverted troughs that suppresses subsidence and the region favors afternoon/early night scattered thunderstorms. Summer 2020 was drier (wetter) than normal in north (southeast) of the country (Fig. 7.53c).

As shown in Fig. 7.54, in 2020, Iran in general received below-normal precipitation for the year. As such, most of the country was drier than normal, especially in the mountainous regions, namely the Zagross in the west and the Alborz in the north and south of the Caspian Sea. Most of the comparatively rainy areas in the subtropical highland country are in northern and western Iran. These areas received below-normal annual precipitation, especially during spring and summer, whereas southeastern Iran, where the annual normal range of precipitation is low (100-150 mm), had normal-to-above normal precipitation.

\section{(III) NOTABLE EVENTS AND IMPACTS}

Heavy rain in southern Iran caused flooding in the Hormozgan Province (north of the Hormoz Strait) on 11 February. The region's Rudan station recorded its highest observed 24-hour accumulated rainfall total of $174 \mathrm{~mm}$.

On 23 March, a strong thunderstorm caused flooding in southern Iran. An accumulated rainfall total of $141 \mathrm{~mm}$ was recorded at the Kahnuj station of Kerman province in southeast Iran-the highest 24-hour amount recorded in the area.

For 3 days in December, low-level easterly currents were coupled with the easterly movement of midlatitude cyclonic activity across a southeastern Mediterranean-Middle East track, triggering heavy rains in the region and over the western windward faces of the Zagross Mountains and flooding the Khuzestan Province plains in the southwest. The 24-hour accumulated rain on 6 December in the region was exceptionally severe, and heavy rain flooded the Khuzestan and north of the Bushehr Provinces on the northwest side of the Persian Gulf. In the city of Ahwaz, the provincial capital, all streets and houses along the Karoon River banks were flooded, killing five people and causing heavy damage to homes and governmental buildings. 
(a) Winter



(b) Spring



(d) Fall



Fig. 7.52. Seasonal surface $(2 \mathrm{~m})$ temperature anomalies $\left({ }^{\circ} \mathrm{C}\right)$ over Iran in (a) winter (top left), (b) spring (top right), (c) summer (bottom left), and (d) autumn (bottom right) 2020. (Source: I. R. of Iran Meteorological Organization.)

Temperatures in the western half of Iran were above normal during November-December and heat waves (five or more days with temperatures $+5^{\circ} \mathrm{C}$ above normal) were recorded at more than 92 stations in that region.

6) Central Asia—W. M. Thiaw, P.-H. Kamsu-Tamo, M. F. Zaheer, and B. Pugh

Central Asia is a landlocked, semi-arid region spanning a wide latitudinal area that extends from the northern temperate zone with Russia at its northern border to the southern subtropics. It exhibits a complex topography ranging from vast plains to high mountains, with the Caspian Sea at its western edge. Its climate is quite diverse and is influenced by the strong inhomogeneity of the terrain. For the purpose of this analysis, Central Asia is defined as the region encompassing the countries of Afghanistan to the south; from east to west, Turkmenistan, Uzbekistan, Tajikistan, and Kyrgyzstan in the central part of the region; and Kazakhstan to the north. Unless otherwise specified, the base period is 1981-2010. 
(a) Winter

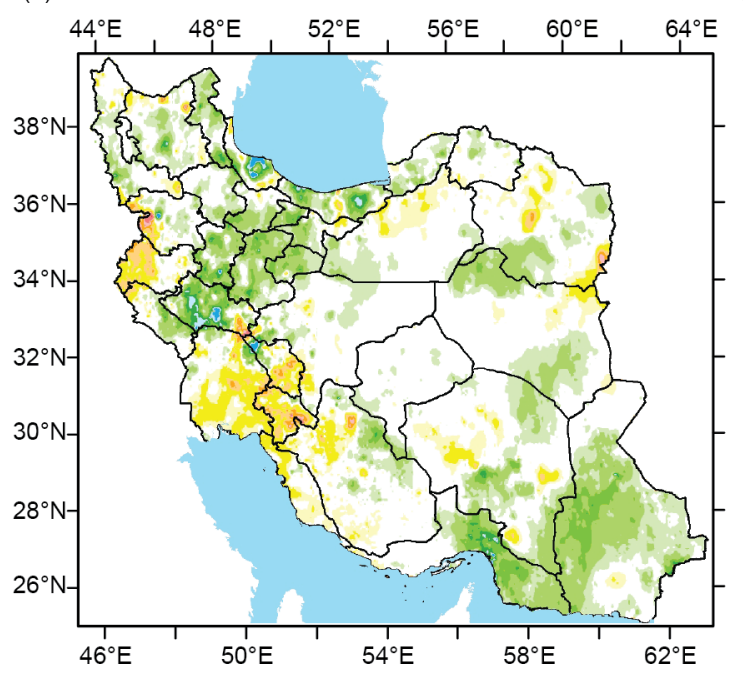

(c) Summer



(b) Spring

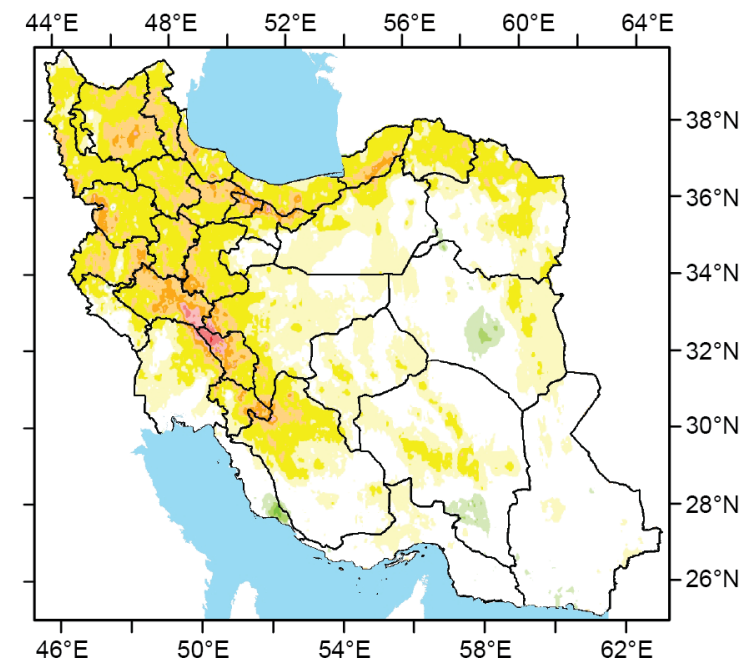

(d) Fall

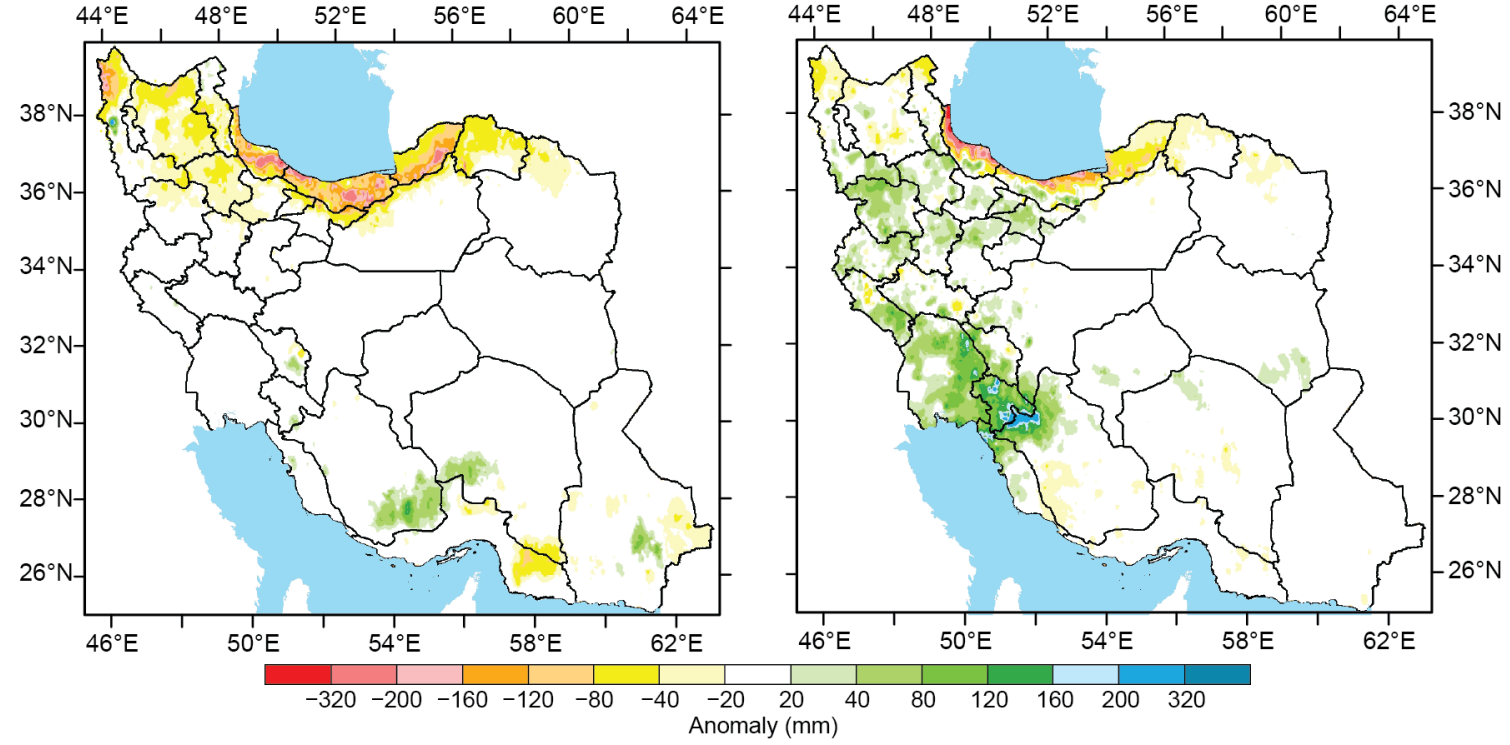

Fig. 7.53. Seasonal precipitation anomalies ( $\mathrm{mm}$; 1984-2019 base period) over Iran in (a) winter (top left), (b) spring (top right), (c) summer (bottom left), and (d) autumn (bottom right) 2020. (Source: I. R. of Iran Meteorological Organization.)



Fig. 7.54. Annual precipitation anomalies (mm; 1984-2019 base period) across Iran in 2020.

\section{(I) TEMPERATURE}

Climatologically, mean annual temperatures are lower $\left(0^{\circ}-10^{\circ} \mathrm{C}\right)$ over the northern and east central areas of the region encompassing northern Kazakhstan, Kyrgyzstan, and Tajikistan, and northeastern Afghanistan. They are higher $\left(15^{\circ}-20^{\circ} \mathrm{C}\right)$ over Uzbekistan, Turkmenistan, and western Afghanistan. During 2020, the mean annual temperature was between $15^{\circ} \mathrm{C}$ and $20^{\circ} \mathrm{C}$ over western Afghanistan, much of Turkmenistan, Uzbekistan, and portions of western Kazakhstan (Fig. 7.55a). Temperatures were lower over northern Afghanistan, Kyrgyzstan, and the northern two-thirds of Kazakhstan, where they averaged between $2^{\circ} \mathrm{C}$ and $8^{\circ} \mathrm{C}$, reaching $0^{\circ} \mathrm{C}$ in western Tajikistan and into below-freezing temperatures in the west. These temperatures were overall below normal across the region, with the lowest temperature anomalies of 
about $-1^{\circ}$ to $-2^{\circ} \mathrm{C}$ in the central areas, encompassing much of Afghanistan, western Turkmenistan and Uzbekistan, eastern Tajikistan, Kyrgyzstan, and southern Kazakhstan (Fig. 7.55b). Temperature departures from average reached $-3^{\circ} \mathrm{C}$ in local areas in northwestern Afghanistan, the far western areas of Turkmenistan and Uzbekistan, and western Tajikistan, making 2020 one of the coldest years in these localities based on the 1981-2010 climatology. Temperatures were slightly above normal over northern Kazakhstan, where anomalies averaged $+0.5^{\circ}$ to $+1.5^{\circ} \mathrm{C}$, with the most elevated temperatures at the 90th percentile rank observed over portions of the northwest and northeast.

An analysis of temperature throughout the year suggests that December was extremely cold in much of Central Asia, with temperatures hovering around $-15^{\circ} \mathrm{C}$ in much of Kazakhstan, and approaching $-20^{\circ} \mathrm{C}$ in some locales in the north, about $5^{\circ}-10^{\circ} \mathrm{C}$ below the mean. Over central and southern Central Asia, mean temperatures averaged about $-10^{\circ} \mathrm{C}\left(5^{\circ}-10^{\circ} \mathrm{C}\right.$ below the mean) in December 2020. Mean temperatures were milder early in the year in January and February, ranging between $-10^{\circ} \mathrm{C}$ and $-15^{\circ} \mathrm{C}\left(5^{\circ}-10^{\circ} \mathrm{C}\right.$ above the mean) over much of Kazakhstan, placing February in the upper 95th percentile rank for this region. They were about $-5^{\circ}$ to $10^{\circ} \mathrm{C}$ in January and February 2020 in the southern and central areas of Central Asia. During the spring and summer months, temperatures soared and exceeded $30^{\circ} \mathrm{C}$ in July over much of Central Asia including western Afghanistan, Turkmenistan, Uzbekistan, and southwestern Kazakhstan. Temperatures were lower in northern Kazakhstan, Tajikistan, and Kyrgyzstan, where they averaged about $20^{\circ} \mathrm{C}$ in July. Temperatures were generally $1^{\circ}-3^{\circ} \mathrm{C}$ below the mean in much of Central Asia during the summer, except for northwestern Kazakhstan in July, where temperatures were about $2^{\circ}-3^{\circ} \mathrm{C}$ above the mean. The spring months of March-May 2020 were also generally $2^{\circ}-10^{\circ} \mathrm{C}$ colder than normal, with the highest departures observed over central Afghanistan.

Annual maximum temperatures $\left(\mathrm{T}_{\max }\right)$ featured a steep north-south temperature gradient with the lowest maximum temperatures (about $4^{\circ} \mathrm{C}$ ) registered in northern Kazakhstan and the highest temperatures (about $15^{\circ}-20^{\circ} \mathrm{C}$ ) observed in Uzbekistan, Turkmenistan, and southern Afghanistan. Afghanistan registered $\mathrm{T}_{\max }$ as high as $25^{\circ} \mathrm{C}$ in its southern tip. However, annual $\mathrm{T}_{\max }$ was generally below the mean over much of the region, with anomalies $-1^{\circ}$ to $-3^{\circ} \mathrm{C}$ over much of Kazakhstan, the western areas of Turkmenistan and Uzbekistan, and Kyrgyzstan, reaching and exceeding $-5^{\circ} \mathrm{C}$ over much of Afghanistan and Tajikistan. The lowest $\mathrm{T}_{\max }$ values (about $-15^{\circ} \mathrm{C}$;
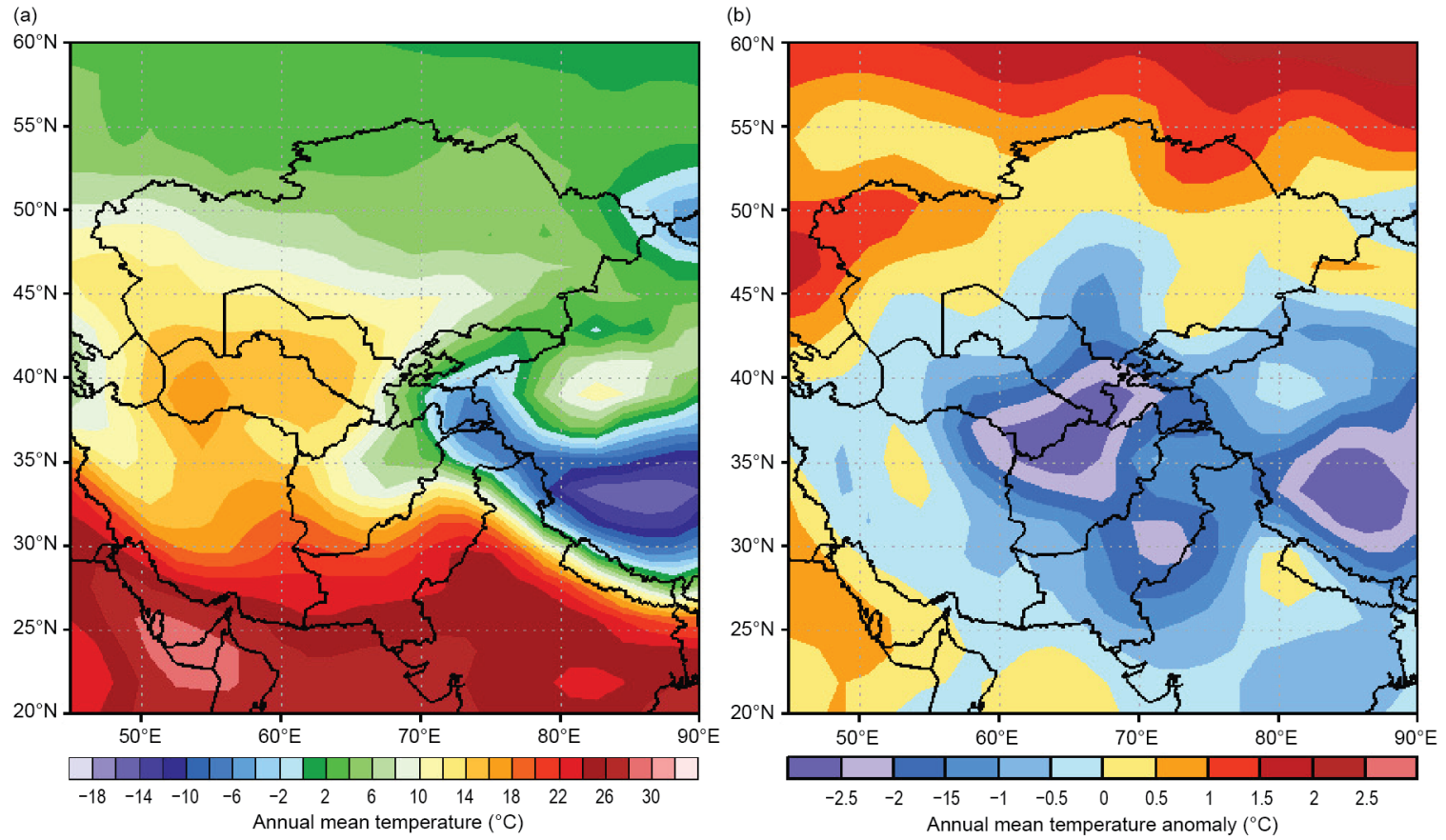

Fig. 7.55. Annual (a) mean temperature $\left({ }^{\circ} \mathrm{C}\right)$ and $(\mathrm{b})$ mean temperature anomalies $\left({ }^{\circ} \mathrm{C}, 1981-2010\right.$ base period) for Central Asia. (Source: NOAA/NCEP.) 
$5^{\circ}-10^{\circ} \mathrm{C}$ below the mean) were observed in northern Kazakhstan in December and the highest $\mathrm{T}_{\max }$ (about $42^{\circ} \mathrm{C} ; 3^{\circ}-5^{\circ} \mathrm{C}$ above the mean) in far western Afghanistan, Turkmenistan, and Tajikistan, and southwestern Kazakhstan in July.

Annual minimum temperatures $\left(\mathrm{T}_{\text {min }}\right)$ ranged between $0^{\circ} \mathrm{C}$ and $5^{\circ} \mathrm{C}$ in northern Afghanistan and much of Kazakhstan. They averaged $10^{\circ}-15^{\circ} \mathrm{C}$ over the western areas of Turkmenistan and southwestern Kazakhstan and $-5^{\circ}$ to $-10^{\circ} \mathrm{C}$ over eastern Tajikistan and southern Kyrgyzstan. $\mathrm{T}_{\min }$ dipped below $-20^{\circ} \mathrm{C}\left(5^{\circ}-10^{\circ} \mathrm{C}\right.$ below the mean) in much of Kazakhstan in December, with some locales in the central areas registering their coldest $\mathrm{T}_{\min }$ on record. However, in July, $\mathrm{T}_{\min }$ approached $25^{\circ} \mathrm{C}\left(1^{\circ}-2^{\circ} \mathrm{C}\right.$ above the mean) in Turkmenistan, Uzbekistan, and southwestern Kazakhstan.

\section{(II) PRECIPITATION}

The mean annual precipitation is quite variable across Central Asia and ranges from less than $200 \mathrm{~mm}$ over southwestern Afghanistan and the central areas of Turkmenistan and Uzbekistan to 200-400 mm over central Afghanistan, the western areas of Turkmenistan and Uzbekistan, eastern Kyrgyzstan, and the southern two-thirds of Kazakhstan. Precipitation is generally higher and about 400-700 mm over northeastern Afghanistan, much of Tajikistan, western Kyrgyzstan, and northern Kazakhstan. Typically, the winter and spring seasons bring the highest precipitation (rain and snow) amounts in the southern and central areas of the region, while the summer months tend to be drier. Precipitation tends to be equally distributed throughout the year over northern Kazakhstan.

The precipitation patterns in 2020 resembled climatology, with average precipitation observed over northern Kazakhstan, Kyrgyzstan, Tajikistan, and northeastern Afghanistan, where totals ranged between $500 \mathrm{~mm}$ and $600 \mathrm{~mm}$, or $80 \%-120 \%$ of normal (Fig. 7.56a). Annual totals were lower (200-500 mm) across much of central and southeastern Kazakhstan, Kyrgyzstan, central Afghanistan, much of Turkmenistan, and western Uzbekistan. Precipitation was less than $200 \mathrm{~mm}$ over the southern tip of Afghanistan, northern Turkmenistan, central Uzbekistan, and local areas in southwestern Kazakhstan. However, precipitation was significantly above average, with surpluses exceeding $100 \mathrm{~mm}$ of normal (120\%-150\% of normal; Fig. 7.56b) over central and southern Afghanistan and eastern Turkmenistan, where totals ranged between $100 \mathrm{~mm}$ and $500 \mathrm{~mm}$, placing some of these localities in the upper 95th percentile rank. Precipitation was below average, about 50-100 mm deficits (50\%-80\% of normal) in western and eastern Kazakhstan.
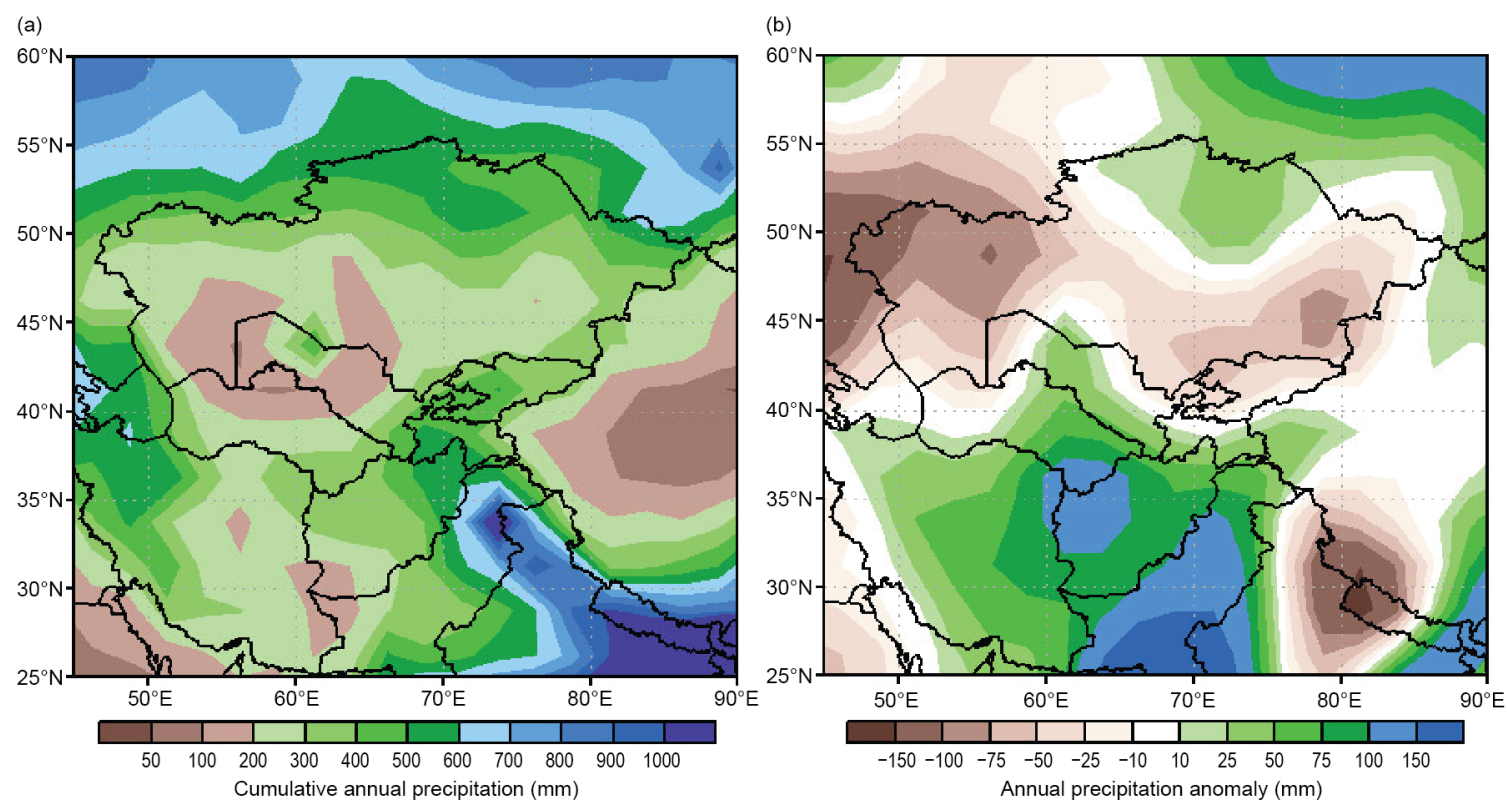

Fig. 7.56. Cumulative annual (a) precipitation $(\mathrm{mm})$ and $(\mathrm{b})$ annual precipitation anomalies (mm; 1981-2010 base period) for Central Asia. (Source: NOAA/NCEP GPCP data.) 
An analysis of precipitation throughout the year reveals surpluses ranging between $30 \mathrm{~mm}$ and $60 \mathrm{~mm}$ (120\%-150\% of normal) over much of northern Kazakhstan during January, February, and April. Surpluses were also evident over much of Afghanistan in April and November, exceeding $100 \mathrm{~mm}$ or $200 \%$ of normal precipitation in some locales.

\section{(III) NOTABLE EVENTS AND IMPACTS}

According to the International Federation of Red Cross and Red Crescent, heavy snowfall, flooding, and a large number of avalanches occurred over many parts of Afghanistan between 12 and 15 January, affecting several provinces including Kandahar, Helmand, and Zabul, with casualties and significant damage to homes and livelihoods. The event caused mass destruction of houses and shelters, loss of lives and public facilities, and displacement of people from their homes. According to the NOAA CPC Satellite Rainfall Estimates version 2 (RFE2), widespread and sustained moderate-to-heavy rain fell across Afghanistan from 20 March to 14 April, with daily estimates exceeding $50 \mathrm{~mm}$ in some locales, resulting in sustained flooding across Afghanistan, Kyrgyzstan, Tajikistan, and the southern areas of Turkmenistan and Uzbekistan. Northern and western Afghanistan received more than $100 \mathrm{~mm}$ of precipitation over this period. The cumulative effect of this precipitation and rapid snowmelt caused severe flooding in more than a dozen provinces of Afghanistan. According to the Afghanistan Natural Disaster Management Authority, about 288 houses were destroyed and an additional 400 were damaged. About 500 ha of land were also damaged, 15 people injured, and 11 fatalities. According to the United Nations, as of April 2020, more than 17,000 people suffered from heavy rains and floods across Afghanistan, with nearly 2000 homes destroyed. Deluge in the Greater Kabul area with rainfall estimates exceeding $100 \mathrm{~mm}$ on 25 and 26 August resulted in a deadly flash floods. According to the Afghan Red Crescent Society Emergency Operations Center, there were 95 casualties, about 140 people injured, 800 houses damaged, and 150 livestock perished.

\section{h. Oceania-C. Ganter, Ed.}

\section{1) Overview-C. Ganter}

The region of Oceania began 2020 with the El Niño-Southern Oscillation (ENSO) in a neutral state, although La Niña emerged in the second half of the year. This was a welcome change for the Australian region, with La Niña contributing to increased rainfall over the continent, after a very significant 2019/20 fire season. Some Southwest Pacific islands observed dry conditions due to La Niña, and the Northwest Pacific and Micronesia region saw a distinct absence of typhoon activity, a classic La Niña signature (see Sidebar 7.3). Parts of New Zealand experienced meteorological drought in early 2020; La Niña conditions contributed to higher temperatures in the latter part of the year.

\section{2) Northwest Pacific and Micronesia-M. A. Lander, C. P. Guard, and B. Bukunt}

This assessment covers the area from the date line west to $130^{\circ} \mathrm{E}$, between the equator and $20^{\circ} \mathrm{N}$. It includes the U.S.-Affiliated Islands of Micronesia, but excludes the western islands of Kiribati and nearby northeastern islands of Indonesia. The analyses are based on station data and anomalies are provided with respect to the 1981-2010 base period.

For much of Micronesia, the weather and climate of 2020 will be remembered for being relatively free of any extremes of wind, waves, or rainfall. Most locations were drier than average during the first half of the year, with an uptick in rainfall (with respect to average) at all locations in the second half of the year. Two locations (Kapingamarangi and Saipan) observed near-record low annual rainfall totals while Kosrae had a record wet year. No typhoons passed through the region during a cyclone season that was remarkably quiet throughout the whole basin (see section 4g7). 


\begin{tabular}{|c|c|c|c|c|c|c|c|c|c|c|}
\hline \multirow[t]{3}{*}{ Location } & \multicolumn{2}{|c|}{$\begin{array}{l}\text { Max Temp } \\
\text { Min Temp }\end{array}$} & \multicolumn{8}{|c|}{ Rainfall (mm) } \\
\hline & Jan-Jun & Jul-Dec & Jan-Jun & Jan-Jun & Jan-Jun & Jul-Dec & Jul-Dec & Jul-Dec & Jan-Dec & Jan-Dec \\
\hline & ${ }^{\circ} \mathrm{C}$ & ${ }^{\circ} \mathrm{C}$ & AVG & 2020 & $\%$ & AVG & 2020 & $\%$ & 2020 & $\%$ \\
\hline Saipan $15^{\circ} \mathrm{N}, 146^{\circ} \mathrm{E}$ & $\begin{array}{l}+1.35 \\
+0.86\end{array}$ & $\begin{array}{l}+1.35 \\
+0.90\end{array}$ & 499.1 & 233.4 & 52.0 & 1322.8 & 1140.7 & 86.2 & 1771.9 & 77.6 \\
\hline Guam $13^{\circ} \mathrm{N}, 145^{\circ} \mathrm{E}$ & $\begin{array}{l}+0.33 \\
+0.33\end{array}$ & $\begin{array}{l}+0.28 \\
+0.38\end{array}$ & 691.6 & 562.36 & 81.3 & 1788.4 & 1701.8 & 95.2 & 2264.2 & 91.3 \\
\hline Yap $9^{\circ} \mathrm{N}, 138^{\circ} \mathrm{E}$ & $\begin{array}{l}-0.09 \\
+0.54\end{array}$ & $\begin{array}{l}-0.46 \\
-0.22\end{array}$ & 1169.7 & 943.9 & 80.7 & 1901.9 & 1937.3 & 101.9 & 2881.1 & 93.8 \\
\hline Palau $7^{\circ} \mathrm{N}, 134^{\circ} \mathrm{E}$ & $\begin{array}{l}-0.08 \\
-0.19\end{array}$ & $\begin{array}{l}+0.03 \\
-0.99\end{array}$ & 1798.1 & 1684.8 & 93.7 & 2279.4 & 2170.2 & 95.2 & 4077.5 & 94.5 \\
\hline Chuuk $7^{\circ} \mathrm{N}, 152^{\circ} \mathrm{E}$ & $\begin{array}{l}+0.54 \\
+1.33\end{array}$ & $\begin{array}{l}+0.80 \\
+0.79\end{array}$ & 1584.2 & 1245.9 & 78.6 & 1833.1 & 2135.4 & 116.5 & 3381.2 & 99.0 \\
\hline Pohnpei $7^{\circ} \mathrm{N}, 158^{\circ} \mathrm{E}$ & -0.56 & -0.62 & 2266.4 & 2143.0 & 94.6 & 2336.6 & 2771.4 & 116.5 & 4914.4 & 106.8 \\
\hline & $n g$ & & 17508 & 1367.0 & 78.1 & 1510.5 & 4364 & 28.9 & 18034 & \\
\hline \multirow{2}{*}{ Kosrae $5^{\circ} \mathrm{N}, 163^{\circ} \mathrm{E}$} & +0.19 & -0.21 & \multirow{2}{*}{2567.9} & \multirow{2}{*}{3119.4} & \multirow{2}{*}{121.5} & \multirow{2}{*}{2342.9} & \multirow{2}{*}{2882.1} & 123.0 & 6001.5 & 122.2 \\
\hline & +0.12 & +0.36 & & & & & & & & \\
\hline Maiurn $7^{\circ} \mathrm{N} 171^{\circ} \mathrm{F}$ & 0.00 & -0.06 & 13683 & 16761 & 1225 & $1868 ?$ & 23282 & 1198 & 30146 & 121 \\
\hline & +0.94 & +1.25 & & 1070.4 & & 1000.2 & & & & \\
\hline Kwajalein $9^{\circ} \mathrm{N}, 168^{\circ} \mathrm{E}$ & $\begin{array}{l}+0.68 \\
+0.74\end{array}$ & $\begin{array}{l}+0.58 \\
+0.56\end{array}$ & 801.4 & 738.4 & 92.1 & 1579.1 & 1579.4 & 100.0 & 2317.8 & 97.4 \\
\hline
\end{tabular}

Approximately two-thirds of locations experienced above-average temperatures. The average 6-month maximum and minimum temperature anomalies and the 6-month and annual rainfall values for select locations across Micronesia are summarized in Table 7.3.

\section{(I) TEMPERATURE}

Across Micronesia, above-average temperatures outweighed below-average temperatures at a ratio of about 60:40 throughout the year. Abnormally clear and dry conditions during the first half of 2020 likely contributed to widespread above-average warmth. Increased cloudiness and rainfall during the second half of 2020 accompanied cooler temperatures with respect to average at some stations. Very warm temperatures are typically experienced in the Micronesian islands when skies are clear and winds are light; cooler temperatures occur when conditions are unusually cloudy, wet, and windy.

\section{(II) PRECIPITATION}

There were two major characteristics of the Micronesian regional precipitation during 2020. Widespread dryness was a major feature of the first half of 2020; however, at most locations the dry conditions were not exceptional. Impacts on crops and water supply were minimal, with the exception of those associated with severe drought on Kapingamarangi (see later discussion). 
Additionally, there were only a few isolated extreme daily rainfall events across the region. On 28 August a thunderstorm over southern Guam produced 150-200 mm of rainfall in about 2 hours over a small area, which resulted in a flash flood of the Umatac River. This flood damaged a few homes and other property, and nearly inundated the Umatac River Bridge, which has a 2.4 m clearance over the base flow. The Army Base at Kwajalein Atoll reported two separate days in September with nearly $125 \mathrm{~mm}$ of rain. Pohnpei and Kosrae received monthly rainfall in excess of $500 \mathrm{~mm}$ for 4 and 5 months of the year, respectively. There were reports of minor flooding of streams and roadways from these two locations.

\section{(III) NOTABLE EVENTS AND IMPACTS}

Historically, most of the islands of Micronesia are dry in years when the climate system is moving toward the cool ENSO phase of La Niña (i.e., the Oceanic Niño Index [ONI] is negative and trending colder) and are wet when the climate system is moving toward the warm phase of El Niño (i.e., the ONI is positive and trending warmer; Table 7.4). Conditions are driest when the ONI starts the year very warm and rapidly cools (i.e., a typical post-El Niño year), and wettest of all when the ONI starts the year cold and rapidly warms (i.e., a typical El Niño onset year). During 2020, the ONI at the beginning of the year was on the warm side of ENSO-neutral and then steadily cooled to La Niña conditions by the boreal autumn. The drier conditions across most of Micronesia in 2020 are likely associated the anomalous cooling of sea surface temperatures (SSTs) in the eastern and central Pacific with the developing La Niña, as indicated by the ONI. Indeed, this was the case for seven of the 10 island locations shown in Table 7.3. Wetter conditions in the second half of the year were not quite sufficient to erase deeper and more widespread dryness in the first half of 2020.

Exceptional dryness was observed in two locations in Micronesia during 2020: Saipan (in the Northern Mariana Islands) and Kapingamarangi (along the equator to the south of Pohnpei Island). Saipan's annual rainfall total of $1172 \mathrm{~mm}$ was the lowest since 1998 (a post-El Niño year). Kapingamarangi's annual rainfall total of $1803 \mathrm{~mm}$ was the second-lowest 12-month sum in its historical record. Saipan's dryness was somewhat isolated as nearby islands such as Guam and Rota had near-average annual totals. The dryness at Kapingamarangi was typical for the onset of La Niña and was well-forecast several months in advance. Impacts of low rainfall on Saipan were minimal during 2020, but on Kapingamarangi, there were severe shortages of potable water in the latter half of 2020, requiring delivery of water supplies by ship.

Table 7.4. NOAA's monthly ONI for 2015-20. Red numbers are at-or-exceeding the El Niño threshold ( $\geq 0.5$ ) for a minimum of five overlapping consecutive seasons to indicate El Niño, blue numbers are at-or-exceeding the La Niña threshold $(\leq-0.5)$ for a minimum of five overlapping consecutive seasons to indicate La Niña, and black numbers are ENSO-neutral. Both 2015 and 2018 (shaded green) were El Niño onset years and behaved as such in Micronesia, with widespread abundant rainfall and enhanced tropical cyclone activity. The years 2016 and 2019 (yellow shading) were both post-El Niño years and behaved as such in Micronesia, with widespread dry conditions in the first half of both of those years and with reduced tropical cyclone activity (especially during 2016). During 2017, the climate system was mostly in a state of ENSO-neutral and the weather across Micronesia was unremarkable. During 2020, the climate system transitioned from ENSO-neutral to La Niña over the course of the year. With a cooling ONI, 2020 was predictably dry, but with an unforeseen remarkable reduction in tropical cyclone activity. Up and down arrows indicate the trend of the ONI during the each of the years.

$\begin{array}{ccccccccccccccc}\text { Year } & \text { JFM } & \text { FMA } & \text { MAM } & \text { AMJ } & \text { MJJ } & \text { JJA } & \text { JAS } & \text { ASO } & \text { SON } & \text { OND } & \text { NDJ } & \text { DJF } \\ 2015 & 0.5 & 0.5 & 0.5 & 0.7 & 0.9 & 1.2 & 1.5 & 1.9 & 2.2 & 2.4 & 2.6 & 2.6 & \uparrow \\ 2016 & 2.5 & 2.1 & 1.6 & 0.9 & 0.4 & -0.1 & -0.4 & -0.5 & -0.6 & -0.7 & -0.7 & -0.6 & \downarrow \\ 2017 & -0.3 & -0.2 & 0.1 & 0.2 & 0.3 & 0.3 & 0.1 & -0.1 & -0.4 & -0.7 & -0.8 & -1.0 & \downarrow \\ 2018 & -0.9 & -0.9 & -0.7 & -0.5 & -0.2 & 0.0 & 0.1 & 0.2 & 0.5 & 0.8 & 0.9 & 0.8 & \uparrow \\ 2019 & 0.7 & 0.7 & 0.7 & 0.7 & 0.5 & 0.5 & 0.3 & 0.1 & 0.2 & 0.3 & 0.5 & 0.5 & \downarrow \\ 2020 & 0.5 & 0.5 & 0.4 & 0.2 & -0.1 & -0.3 & -0.4 & -0.6 & -0.9 & -1.2 & -1.3 & -1.2 & \downarrow\end{array}$


Conversely, heavy rainfall was noted in two locations: Majuro (in the Republic of the Marshall Islands) and at Kosrae (the easternmost island of the Federated States of Micronesia). Kosrae received $6002 \mathrm{~mm}$ of annual rainfall, its highest annual total with records dating to 1986. Majuro Atoll also had high monthly rainfall throughout 2020, with an annual total of $3915 \mathrm{~mm}$. This was the 17th-highest amount in the station's 67-year historical record. With La Niña becoming stronger through the end of the year, the east-west cloud band commonly identified as the Intertropical Convergence Zone (ITCZ) was persistent and continually confined to a narrow latitudinal band that encompassed Kosrae $\left(5.3^{\circ} \mathrm{N}\right)$ and Majuro $\left(7.1^{\circ} \mathrm{N}\right)$, but strayed only infrequently to islands farther north (e.g., Kwajalein, Guam, and Saipan) or islands farther south (e.g., Kapingamarangi). Heavy rainfall is generally not a problem for atolls-in fact, it is welcome-where it rapidly and harmlessly finds its way to the sea. Kosrae is a high island and can experience unwanted flooding, but given that the annual average rainfall there is near $5000 \mathrm{~mm}$, residents are accustomed to extreme rainfall and have adapted accordingly.

Sidebar 7.3: Clear La Niña signal in Micronesian typhoon tracks of 2020—M. A. LANDER, C. P. GUARD, AND B. BUKUNT

The year 2020 is a classic example of the effect that La Niña can have on typhoon tracks across the Micronesia region. Almost no tropical cyclone (TC) activity occurred near the islands of Micronesia, apart from a few showery days as the precursor disturbances to a few of the western North Pacific basin's named storms harmlessly passed by.

In general, El Niño years are associated with an eastward displacement of TC activity and La Niña years are associated with a westward displacement of TC activity in the western North Pacific, with a dramatic effect on the distribution of TCs in Micronesia. Figure SB7.5 shows a comparison of the tropical cyclone tracks during opposite phases: 2015 (El Niño) and 2020 (La Niña).
During 2020, the Joint Typhoon Warning Center (JTWC) observed 26 tropical cyclones in the western North Pacific basin that included 12 typhoons, 12 tropical storms, and two tropical depressions. The JTWC average annual counts of typhoons, tropical storms, and tropical depressions are 18, 10, and three, respectively. The Japan Meteorological Agency named 23 storms, which included only eight typhoons and 15 tropical storms. There was a large westward displacement to the genesis locations and tracks of the $2020 \mathrm{TCs}$, which is the primary reason for the notable absence of TCs in Micronesia. Conversely, the east coast of China, Vietnam, and Korea experienced the brunt of the impacts from the tropical cyclones of 2020 (see sections $4 \mathrm{~g} 4$ and $7 \mathrm{~g} 4$ for more details).

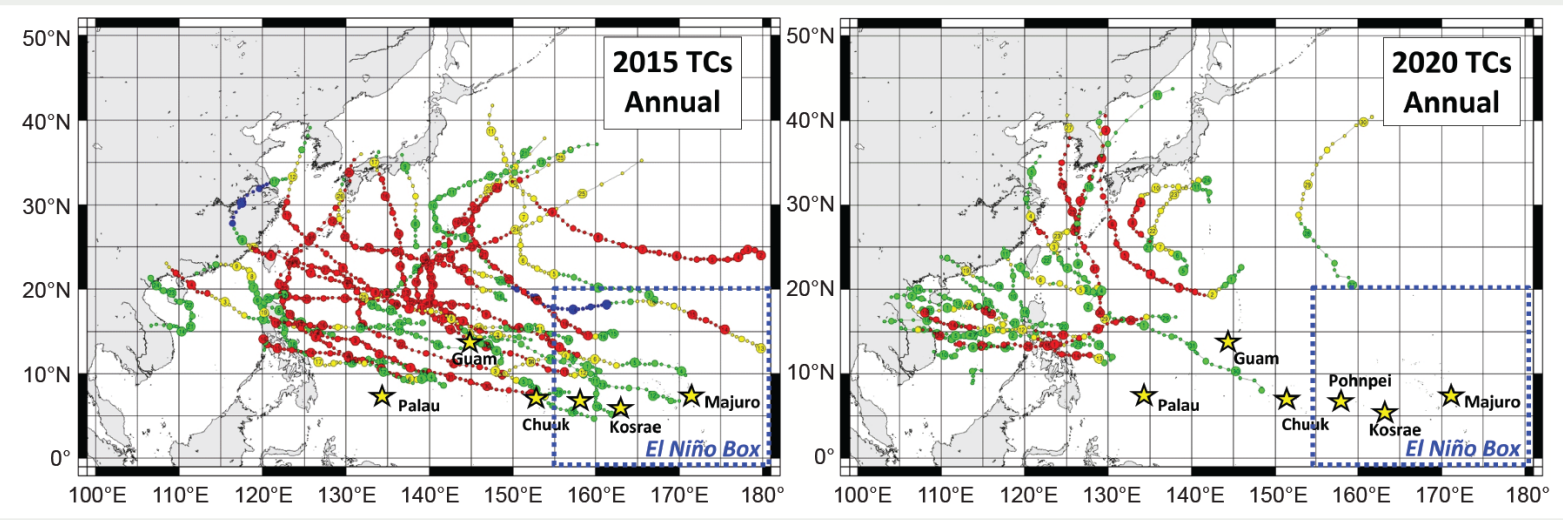

Fig. SB7.5. The typhoon tracks of 2015 (strong El Niño) and of 2020 (La Niña onset) are shown to illustrate the dramatic changes that can occur to the distribution of TCs in the western North Pacific from the state of ENSO. The islands of Micronesia (yellow stars) are profoundly affected, with TCs occurring in the "El Niño Box" almost exclusively during El Niño years. These typhoon track charts were adapted from the output of the plotting utility on the "digital typhoon" web site: http://agora.ex.nii.ac.jp/digital-typhoon/. Dot colors indicate the following: tropical storm (green), severe tropical storm (yellow), typhoon (red), and subtropical (blue). 


\section{3) Southwest Pacific-E. Chandler}

Countries considered in this section include American Samoa, Cook Islands, Fiji, French Polynesia, Kiribati, New Caledonia, Niue, Papua New Guinea (PNG), Samoa, Solomon Islands, Tonga, Tuvalu, Vanuatu, and Wallis and Futuna. The temperature analysis is based on the Climate Anomaly Monitoring System (CAMS) monthly surface air temperature anomalies (https: //iridl.ldeo.columbia.edu/maproom/Global/Atm_Temp/Anomaly.html). Anomalies are with respect to the 1971-2000 base period. The precipitation analysis is based on monthly analyses presented in the Climate and Oceans Support Program in the Pacific (COSPPac) Monthly Bulletin (https://www.pacificmet.net/products-and-services/climate-bulletin) and COSPPac Online Climate Outlook Forum (https://www.pacificmet.net/products-and-services/online-climate-outlook -forum). The base period for precipitation is 1979-95.

The year began in an ENSO-neutral state, which persisted until the middle of 2020 before transitioning to La Niña conditions (see section $4 \mathrm{~b}$ for details). SSTs were persistently warm across the equatorial Pacific through the first half of 2020 before retracting to the west later in the year as the equatorial water cooled. Atmospheric indicators of the developing La Niña event became evident in the middle of the year, with strengthening equatorial trade winds and a reduction in cloud and rainfall near the date line. Precipitation was below normal for most of the year along the equator, with the strongest suppression of rainfall in the western Pacific in the later part of the year. Air temperatures were close to normal for most of the year, but became below average along the equator as La Niña strengthened toward the end of the year.

\section{(I) TEMPERATURE}

Air temperatures were near normal across most of the southwest Pacific during the first quarter of 2020 (Fig. 7.57a), apart from $+1^{\circ}$ to $+2^{\circ} \mathrm{C}$ positive anomalies in a region centered on the equator and stretching from north of PNG to the Line Islands in Kiribati. By March, the warm anomalies extended southward, covering eastern PNG, the Solomon Islands, and northern Vanuatu. This region of above-normal air temperatures was associated with the above-normal equatorial SSTs in the same region.
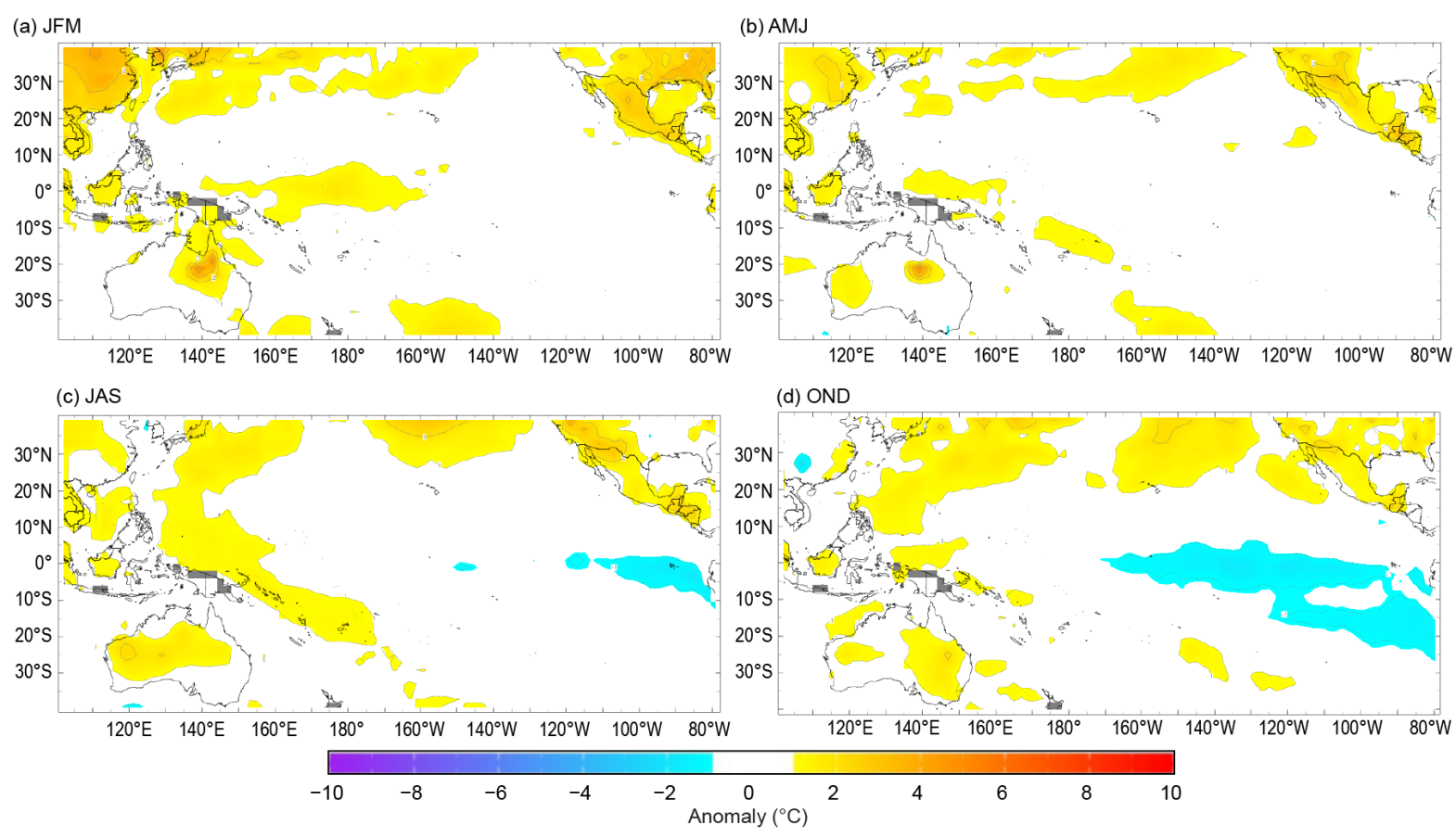

Fig. 7.57. Global seasonal temperature anomalies $\left({ }^{\circ} \mathrm{C}\right)$ for (a) JFM, (b) AMJ, (c) JAS, and (d) OND. (Source: CAMS.) 
Warm equatorial anomalies weakened in the second quarter of the year (Fig. 7.57b), with temperature anomalies of $+1^{\circ}$ to $+2^{\circ} \mathrm{C}$ persisting only in the far western Pacific near PNG by June. Small regions of positive anomalies occurred later in the quarter over the Solomon Islands and across a region extending southeast to include Niue, Tonga, and the southern Cook Islands.

In July, August, and September (Fig. 7.57c) the area of positive anomalies expanded to encompass a broad region stretching from northern PNG in a southeast direction to Fiji and Tonga, with anomalies in the $+1^{\circ}$ to $+2^{\circ} \mathrm{C}$ range. In contrast, the emerging La Niña was associated with negative anomalies developing off the South American coast and along the eastern equatorial Pacific. Small regions of $-1^{\circ}$ to $-2^{\circ} \mathrm{C}$ anomalies extended west as far as eastern Kiribati.

The positive anomalies that previously extended southeast from PNG receded during October-December (OND), though some smaller regions remained warmer than average, associated with persistently warm ocean temperatures in the far western South Pacific. Negative anomalies expanded westward along the equator through the last quarter of 2020 as La Niña strengthened, with air temperatures $1^{\circ}-2^{\circ} \mathrm{C}$ below normal across Tokelau, eastern Kiribati, northern Cook Islands, and French Polynesia (Fig. 7.57d). However, by December 2020 these cool anomalies had begun to contract both in spatial extent and strength of the departure from normal.

In summary, temperatures during 2020 were close to normal across much of the southwest Pacific, with the notable exception of a large region of $+1^{\circ}$ to $+2^{\circ} \mathrm{C}$ anomalies occurring southeast from PNG through Fiji for much of the year. The warmth was most extensive during the middle of the year. In the second half of the year, the developing La Niña was associated with belownormal temperatures extending from South America along the equator to eastern Kiribati. These negative anomalies were most extensive during October-December.

\section{(II) PRECIPITATION}

Typical of a neutral-ENSO state, the region experienced a mixed rainfall pattern in the first quarter of 2020. The South Pacific Convergence Zone (SPCZ) was located on or shifted slightly to the north of its long-term position in January and February before shifting southward to the east of the Solomon Islands in March, bringing it close to Vanuatu and Fiji (Figs. 7.58a-c). Located on the date line, a region of above-average rainfall stretched eastward along the equator during January and February. As a result, rainfall above the 90th percentile for January-March (JFM) was recorded in western Kiribati, Samoa, and Tuvalu, while Savusavu Airport on Vanua Levu, Fiji, recorded its driest JFM in 59 years of record $(359 \mathrm{~mm})$.

The SPCZ was south of its long-term average position east of the Solomon Islands during April, while during May and June, the SPCZ was largely suppressed (Figs. 7.58d-f). Rainfall for the April-June (AMJ) quarter was reduced along the equator in early signs of the developing La Niña, with the strongest negative anomalies on and to the west of the date line. Conversely, rainfall was enhanced from northern Vanuatu eastward to Niue and Samoa during April and again during June. Rainfall for AMJ was above the 90th percentile in southern Fiji, Niue, Samoa, Tonga, and Vanuatu. Two stations in Vanuatu recorded their highest AMJ rainfall on record: Sola (1895 mm, 46-year record) and Pekoa (1517 mm, 50-year record). In contrast, rainfall below the 10th percentile was observed in the Gilbert Island group of Kiribati and the northern PNG Islands.

During July-September (JAS), the ocean surface cooled along the equator, as expected with the developing La Niña. Rainfall continued to be suppressed in this region, with the largest anomalies to the north of PNG and the Solomon Islands. Western Kiribati received JAS rainfall below the 10th percentile. Meanwhile, the SPCZ was displaced south of its normal position over the Solomon Islands (Figs. 7.58g-i), contributing to rainfall above the 90th percentile in northern Fiji, Samoa, Solomon Islands, Tonga, and, particularly due to heavy rainfall during July, in a large region extending from the Solomon Islands to southern French Polynesia. Auki in the eastern Solomon Islands recorded its wettest JAS in its 58-year record (1101 mm). 

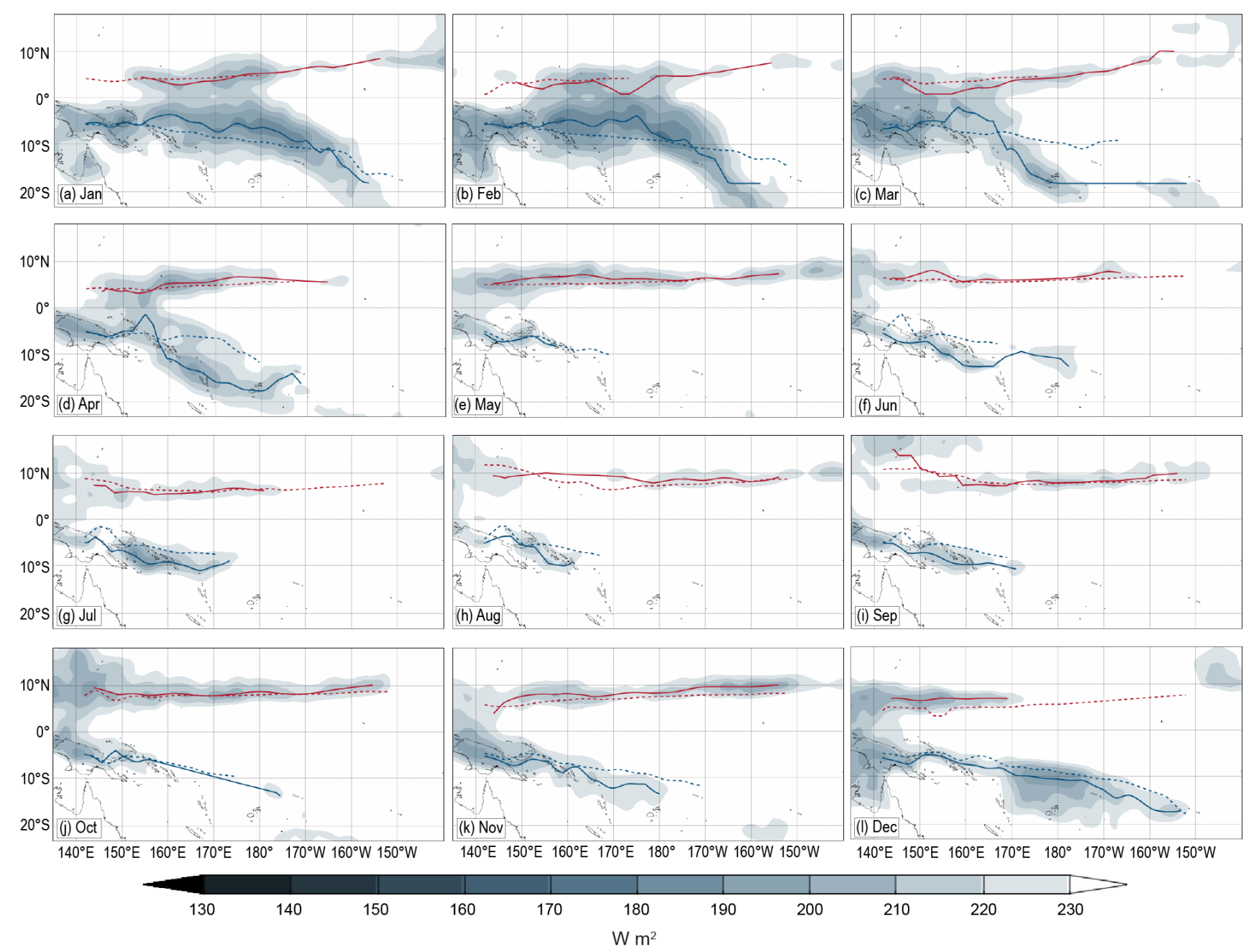

Fig. 7.58. Monthly South Pacific Convergence Zone (SPCZ) locations determined by OLR measurement for 2020. The blue line indicates SPCZ and the red line indicates the ITCZ, with dashed lines indicating the respective 1981-2010 climatological positions. (Source: Australian Bureau of Meteorology.)

Rainfall patterns during the last quarter of 2020 reflected an established La Niña. The SPCZ continued to be suppressed during October, then became active during November and December (Figs. 7.58j-1). The active SPCZ near the date line in December was associated with enhanced rainfall and tropical cyclone activity (see Notable events and impacts). Overall, there was a broad region near the equator with suppressed rainfall. Regions that recorded rainfall below the 10th percentile include the northern Cook Islands, western Kiribati, the northern Solomon Islands, and Tuvalu. Beru (Kiribati) recorded its second-driest OND in its 62-year record (12 mm). Conversely, there was also a broad band of enhanced rainfall in the South Pacific near the date line during this period, with totals above the 90th percentile recorded in several areas, including Fiji, northwestern PNG, Samoa, and Tonga. Faleolo (Samoa) recorded its third-wettest OND in the 58-year record (1135 mm).

In summary, rainfall in the southwest Pacific in 2020 was suppressed along the equator from April onward, associated with the transition from ENSO-neutral to La Niña. Below-normal rainfall was particularly evident in the western South Pacific later in the year, with strong suppression of rainfall in a broad region to the north of PNG and the Solomon Islands. Many South Pacific Islands experienced a wetter-than-normal start to the dry season. Numerous locations on and to the east of the date line that are influenced by the SPCZ observed enhanced rainfall toward the end of the year, including that associated with two cyclones that formed in December (see Notable events and impacts). 


\section{(III) NOTABLE EVENTS AND IMPACTS}

Severe tropical cyclone Harold formed east of PNG in early April and moved southeast toward the Solomon Islands. By 4 April, Harold had reached Category 4 status, strengthening to Category 5 the next day before making landfall on 6 April over Espiritu Santo in southern Vanuatu. At Harold's peak there were 10-minute sustained winds of $230 \mathrm{~km} \mathrm{~h}^{-1}$ as the storm moved east away from Pentecost, Vanuatu. On 7 April Harold approached Suva, Fiji, before continuing southeast across the Tongan island of Tongatapu and to the south of its capital Nuku'alofa. The impacts from Harold were felt across several countries: in the Solomon Islands, 27 people drowned when they were washed overboard from a ship. There were two fatalities on Malo Island, Vanatu, while one person died and another 26 reported injuries across Fiji. Extensive damage occurred in the Solomon Islands, Vanuatu, Fiji, and Tonga, including ships washed ashore, buildings, houses, and bridges destroyed or damaged by wind as well as coastal and river inundation. There was also a loss of telecommunications and electricity, and water shortages were experienced in many areas. Several villages were evacuated due to flash flooding and inundation, and localized crop damage was reported. See section $4 \mathrm{~g} 8$ for more details.

On 13 December, Tropical Cyclones Yasa and Zazu were both named after two tropical disturbances reached TC thresholds. Yasa was the most intense tropical cyclone of 2020, with a minimum barometric pressure of $899 \mathrm{hPa}$ and maximum 10-minute sustained winds of $250 \mathrm{~km} \mathrm{~h}^{-1}$. Yasa formed to the east of Vanuatu and moved in a southeasterly direction. The storm quickly intensified to Category 5 on 14 December, making it the earliest date on record that a Category 5 cyclone formed in the southwest Pacific. Yasa passed over Vanua Levu, Fiji, bringing wind gusts of up to $345 \mathrm{~km} \mathrm{~h}^{-1}$, causing widespread destruction of buildings and crops; four people died. There was localized flooding and high rainfall over many highly populated areas, resulting in the loss of power, water supply, roads, and phone connections. Zazu, in comparison, formed near Niue and reached a Category 2 status on 15 December. The storm brought high rainfall and heavy surf that damaged Niue's wharf, before tracking to the south and away from populated areas.

\section{4) Australia-S. Tobin}

For this section, monthly area-averaged temperatures are based on the ACORN-SAT dataset v2.1 (Trewin 2018), which begins in 1910. Daily temperatures and mapped temperature analyses are based on the Australian Water Availability Project (AWAP) dataset (Jones et al. 2009), which begins in 1910 for temperature. Area-averaged rainfall values and mapped analyses use the new Australian Gridded Climate Data (AGCD) dataset (Evans et al. 2020), which begins in 1900.

\section{(I) TEMPERATURE}

The year 2020 was Australia's fourthwarmest year in its 111-year record. The area-averaged annual mean temperature was $0.76^{\circ} \mathrm{C}$ above the $1981-2010$ average. The warmest year on record was 2019 $\left(+1.13^{\circ} \mathrm{C}\right)$. The annual nationwide mean maximum temperature (Fig. 7.59) was the

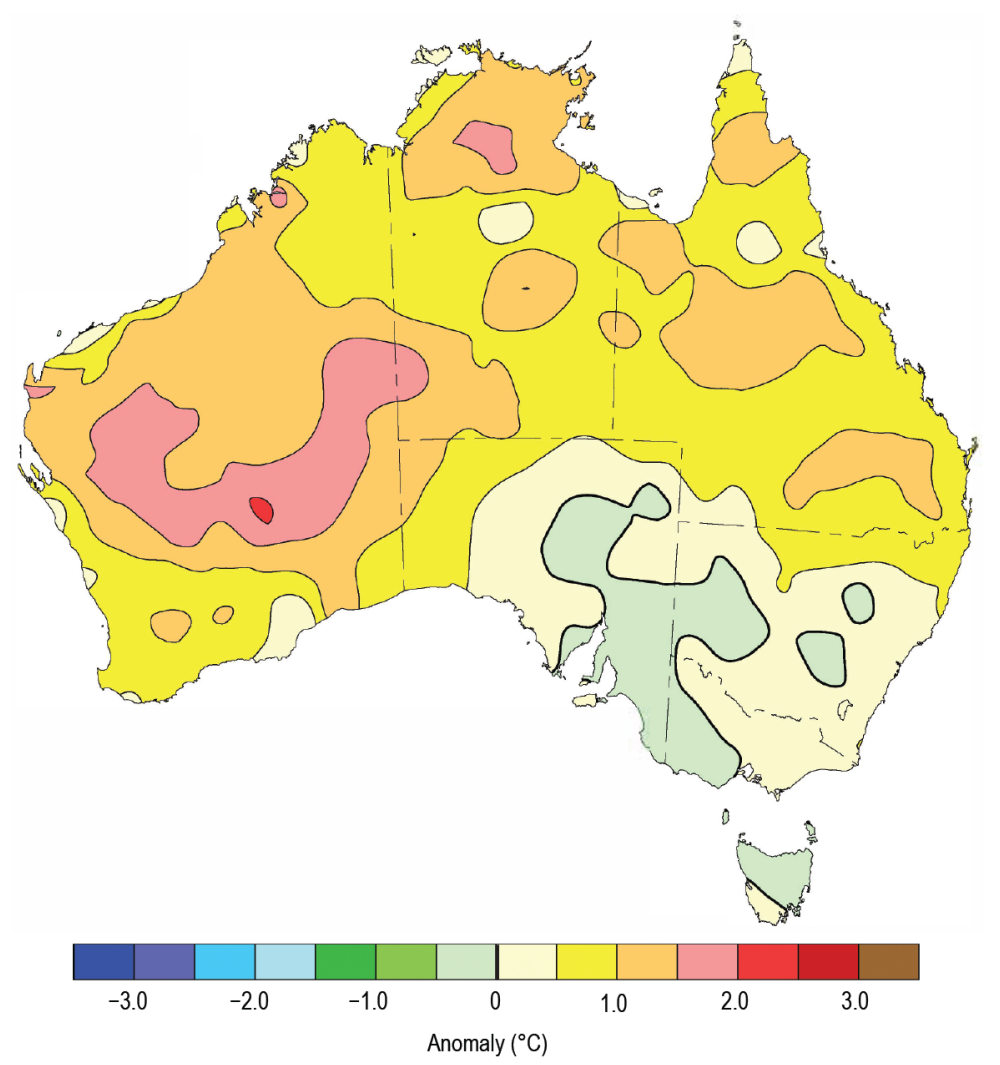

Fig. 7.59. Maximum temperature anomalies $\left({ }^{\circ} \mathrm{C}\right)$ for Australia, averaged over 2020, relative to a 1981-2010 base period. (Source: Australian Bureau of Meteorology.) 
eighth highest on record at $0.86^{\circ} \mathrm{C}$ above average. The mean minimum temperature (Fig. 7.60) was $0.67^{\circ} \mathrm{C}$ above average, the fourth highest on record.

Annual mean temperatures were above or very much-above average for most of Australia and in the highest $10 \%$ of historical observations for most of Western Australia, the Northern Territory, Queensland, and along the coast of New South Wales and far eastern Victoria.

Mean maximum temperatures were wellabove average across most of Australia, but close to average for much of the inland southeast away from the east coast. They were in the highest $10 \%$ of historical observations for most of Western Australia, the Northern Territory, and Queensland away from the southwest.

Mean minimum temperatures were above average for much of the country, but close to average for eastern South Australia, northwestern Victoria, and southwestern New South Wales. Annual mean minima were in the highest $10 \%$ of historical observations for most of Western Australia, western South Australia, much of the Northern Territory and Queensland, and along the east coast.

Warmth was widespread and persistent through the year-the national mean temperature was among the 10 highest on record for seven of the 12 months of the year. Both November and spring as a whole had record high temperatures.

An increased diurnal temperature range is common in inland eastern Australia when rainfall is low during the cooler months of the year. Minimum temperatures during the middle months of 2020 were below average over much of southeastern Australia while mean maximum temperatures were above or well-above average over most of Australia.

\section{(II) PRECIPITATION}

Averaged across Australia, rainfall for 2020 was $485.5 \mathrm{~mm}$, very close to the 19812010 average of $481.6 \mathrm{~mm}$. Compared to the 1900-2020 distribution, annual rainfall was below average for parts of southeastern and east coast Queensland, the west and

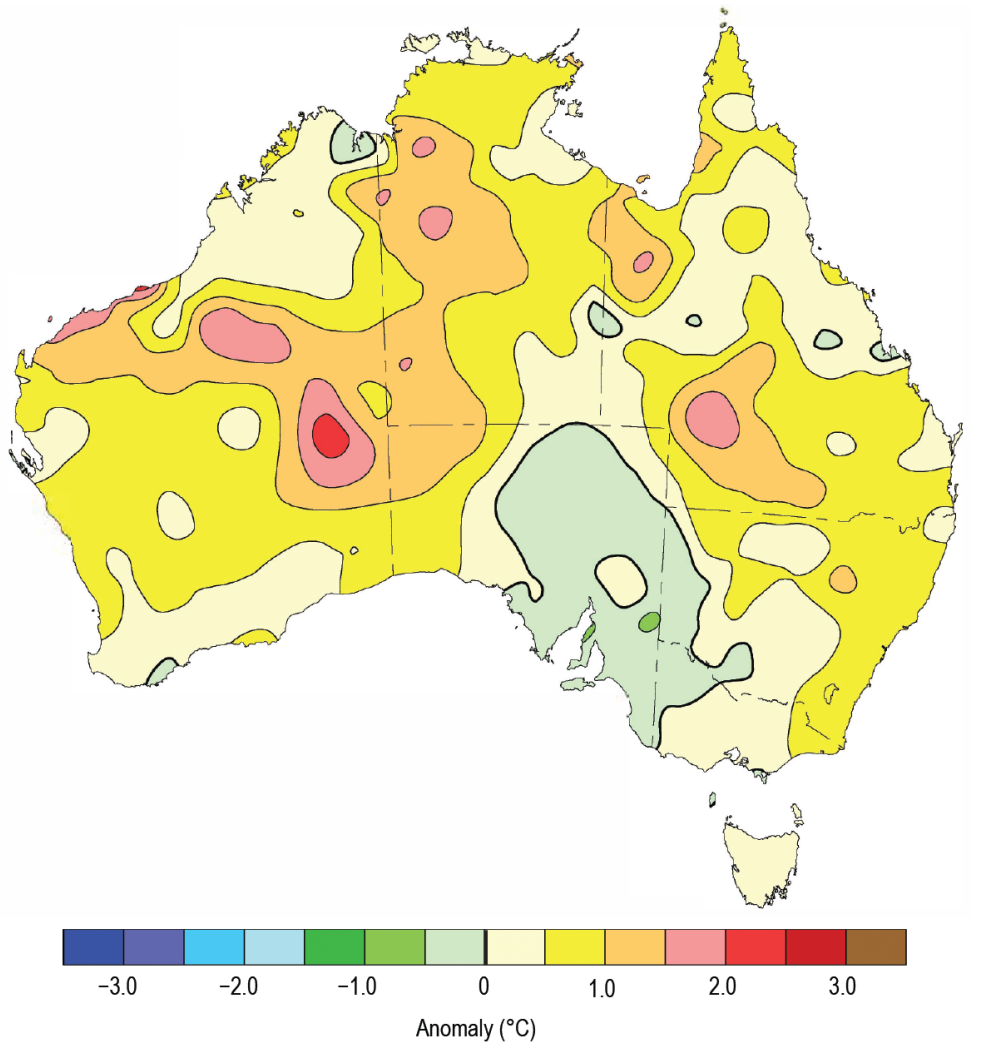

Fig. 7.60. Minimum temperature anomalies $\left({ }^{\circ} \mathrm{C}\right)$ for Australia, averaged over 2020, relative to a 1981-2010 base period. (Source: Australian Bureau of Meteorology.)

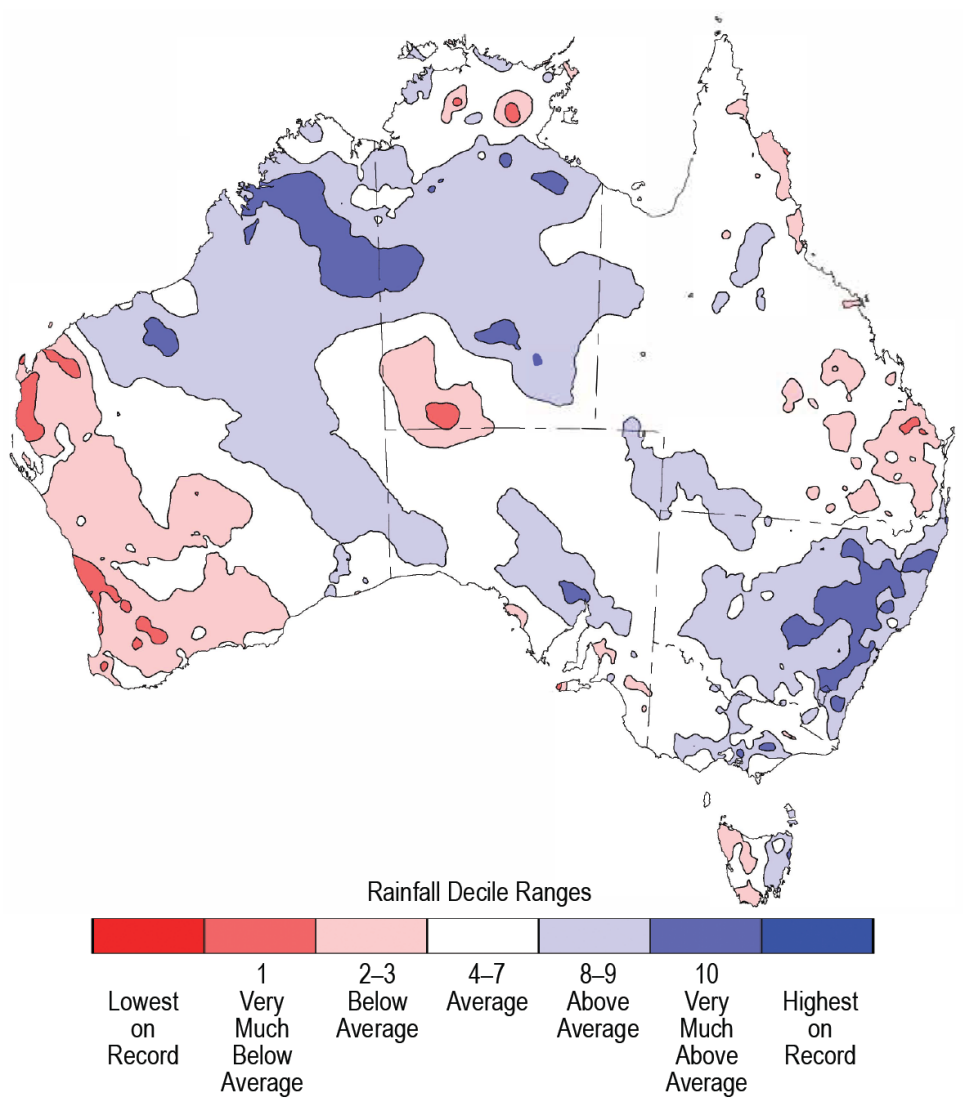

Fig. 7.61. Rainfall deciles for Australia for 2020, based on the 1900-2020 distribution. (Source: Australian Bureau of Meteorology.) 
southwest of Western Australia, and western Tasmania (Fig. 7.61). Annual rainfall was above average across large parts of New South Wales, much of northern and eastern Western Australia, and much of the Northern Territory.

Above-average rainfall in the northwest was largely a result of tropical systems during December, whereas in New South Wales, contributions were spread across the year, mostly during February-April, August-October, and December.

Rainfall was above average for large parts of eastern Australia during February-April. The middle of the year was notably drier, with May-July rainfall being below or well-below average across much of the southern half of Australia. For the southern Australian region (south of $26^{\circ} \mathrm{S}$ ), May-July rainfall was the seventh lowest in the 121-year record.

During late winter to early spring, both the developing La Niña and negative Indian Ocean dipole-like state of the Indian Ocean (see section $4 \mathrm{f}$ for details of the Indian Ocean dipole) favored above-average rainfall over eastern and southern Australia. A temporary weakening of La Niña during November brought below- or very-much-below-average rainfall to much of the eastern two-thirds of Australia, while tropical lows in the north and a slow-moving low and coastal trough in the east contributed to Australia's fourth-wettest December on record.

Following Australia's driest year on record in 2019, and protSracted widespread low rainfall since late 2016, there were significant rainfall deficiencies in place across much of Australia at the start of 2020. While water storages in the southern Murray-Darling Basin saw significant increases during 2020, storage levels in the northern Basin remained low at the end of the year.

Farther west, large areas of Western Australia saw very little rain from April to July, and shortterm rainfall deficiencies emerged in the southwest in addition to existing multi-year rainfall deficiencies in the region where climatologically May, June, and July are the wettest 3 months of the year.

\section{(III) NOTABLE EVENTS AND IMPACTS}

The last days of 2019 and first days of 2020 saw particularly hazardous fire weather. Extremely high temperatures across parts of southeastern Australia and northerly winds driven by a cold front and trough contributed to significant increases in the number and size of active fires in eastern Australia (BoM 2020) where multiple fires had been burning since austral spring 2019. Extreme heat again affected southeastern Australia at the end of January and beginning of February.

Severe storms affected southeast Australia during mid-to-late January including heavy rainfall, hail up to $6 \mathrm{~cm}$ in diameter, and damaging winds. One of the most severe hailstorms on record in Canberra occurred on 20 January. Estimates of insured losses across Canberra, Melbourne, and Sydney reached \$320 million Australian dollars ( \$240 million U.S. dollars).

Accumulation of heat in the ocean waters east of Queensland during February and into March led to coral bleaching across the Great Barrier Reef. This was the third mass-bleaching event to affect the reef in 5 years.

Widespread heavy rainfall during the first half of February across much of Queensland and along the east coast of Australia contributed to both riverine and flash flooding in parts of southeast, southern, and inland Queensland and eastern New South Wales. Renewed heavy rainfall at the end of February and early March, partly associated with the remnants of Tropical Cyclone Esther (see section 4g7), led to further widespread flooding in Queensland and heavy rainfall as far south as Victoria.

Heat built in northwestern Australia during August, with records set at a large number of stations in northern Western Australia during the last week of the month. Some stations broke their previous August record multiple times during the event.

Heat waves also affected large areas in November, including much of northwest to southeast Queensland around the middle of the month and much of southeast and eastern Australia toward 
the end of the month. Large areas experienced daily maximum temperatures more than $10^{\circ} \mathrm{C}$ above average over a number of days. Extreme heat continued into the first days of December.

A slow-moving low-pressure system and coastal trough resulted in very heavy rainfall and flooding for parts of northeastern New South Wales and southeastern Queensland during midDecember.

For further detail on these and other significant events, please see Special Climate Statements, Monthly Weather Reviews, and the Annual Climate Statement at http://www.bom.gov.au/climate /current.

\section{5) Aotearoa New Zealand-Gregor Macara}

In the following discussion, the base period is 1981-2010. The nationwide average temperature is based upon the National Institute of Water and Atmospheric Research (NIWA) sevenstation temperature series that began in 1909 (see https://www.niwa.co.nz/our-science/climate /information-and-resources/nz-temp-record/seven-station-series-temperature-data). The precipitation and temperature anomaly maps were generated using interpolation of observed data from New Zealand's climate monitoring network.

\section{(I) TEMPERATURE}

The year 2020 was Aotearoa New Zealand's seventh-warmest year since records began in 1909. The nationwide average temperature was $13.24^{\circ} \mathrm{C}, 0.63^{\circ} \mathrm{C}$ above the $1981-2010$ normal. Annual mean temperatures were above average $\left(+0.51^{\circ}\right.$ to $\left.+1.20^{\circ} \mathrm{C}\right)$ across much of the North Island and many parts of the South Island. Near-average (within $0.50^{\circ} \mathrm{C}$ of average) temperatures occurred in much of Southland, eastern and inland Otago, coastal Canterbury, West Coast, Marlborough, coastal parts of the southern North Island, and the Central Plateau (Fig. 7.62a). Air flow anomalies over New Zealand transitioned to northeasterly during winter, which persisted over the North
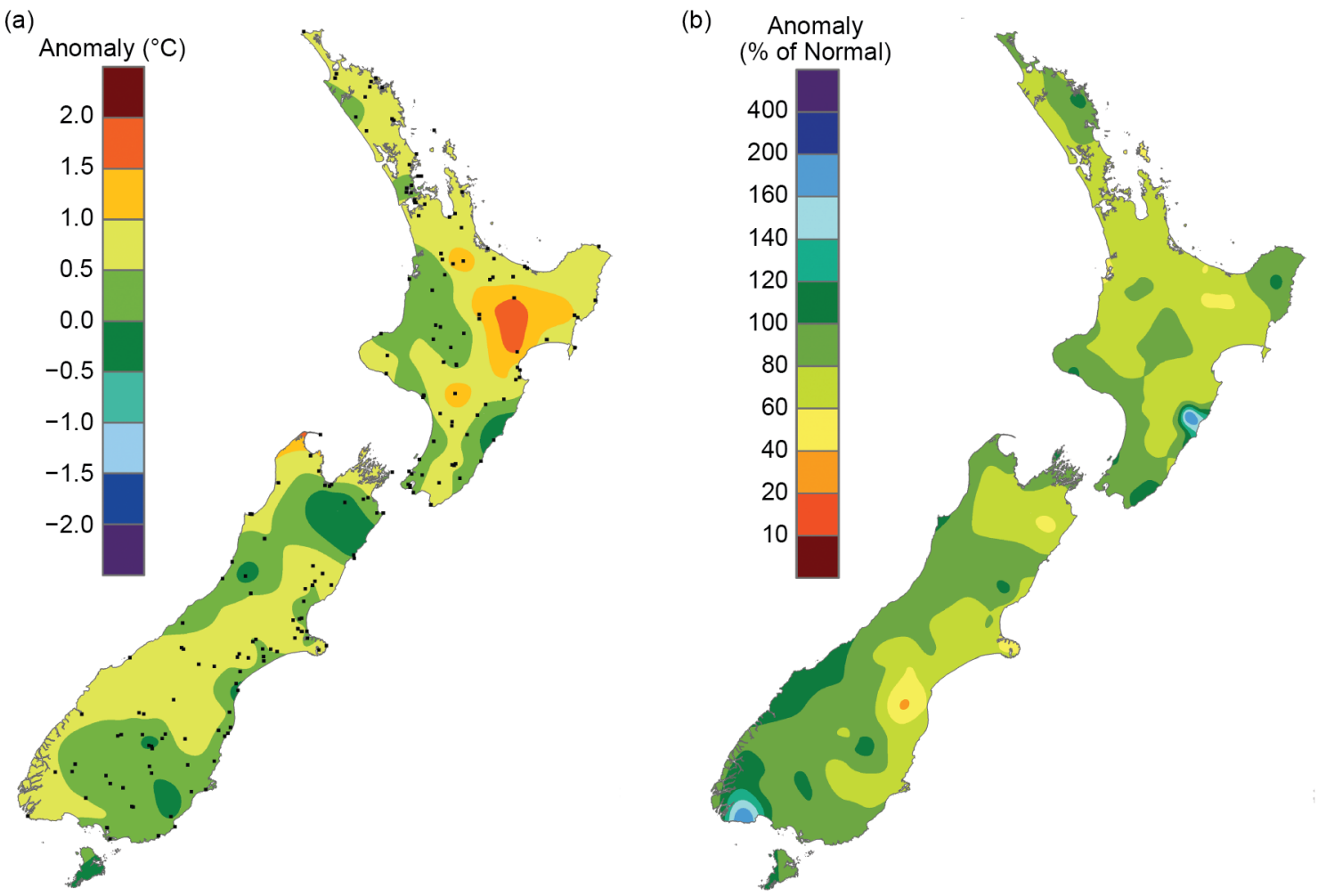

Fig. 7.62. Annual (a) average temperature anomaly $\left({ }^{\circ} \mathrm{C}\right)$ and $(\mathrm{b})$ total rainfall ( $\left.\%\right)$ for 2020 , relative to the $1981-2010$ base period. The dots on (a) represent the locations of climate stations used to create both the temperature and rainfall maps. (Source: NIWA.) 
Island through spring; this is a traditional hallmark of La Niña, which contributed to the observed above-average temperatures. Relatively hot conditions occurred during the end of January and early in March, with four locations across the northern North Island experiencing their highest daily temperature on record. The highest temperature of 2020 was recorded on 31 January at Gisborne $\left(38.2^{\circ} \mathrm{C}\right)$, which was New Zealand's fifth-highest January temperature on record and tied as the 19th-hottest temperature on record for all months. This heat contributed to the warmest winter on record for the country, with a nationwide average temperature of $9.6^{\circ} \mathrm{C}, 1.1^{\circ} \mathrm{C}$ above average. The lowest air temperature of the year was $-12.3^{\circ} \mathrm{C}$, recorded at Middlemarch (Otago, South Island) on 14 June.

\section{(II) PRECIPITATION}

Annual rainfall totals for 2020 were below normal (50\%-79\% of normal) across many northern, eastern, and inland parts of the North Island and parts of Marlborough, Canterbury, and eastern Otago on the South Island. Fourteen locations observed record low or near-record low rainfall totals. Rainfall was near normal ( $80 \%-119 \%$ of normal) for most of the remaining areas of the country including eastern parts of Northland, the Central Plateau, western and southern parts of the North Island, Nelson, West Coast, inland Otago, and Southland (Fig. 7.62b). Hamilton (Waikato, North Island) observed its driest year since records began in 1905. Of the regularly reporting rainfall gauges, the wettest location in 2020 was Cropp River in the Hokitika River catchment (West Coast, South Island, $975 \mathrm{~m}$ above sea level), with an annual rainfall total of 11,532 mm. The driest of the regularly reporting rainfall sites in 2020 was Hakataramea Valley (inland South Canterbury), which recorded $205 \mathrm{~mm}$ of rainfall.

\section{(III) NOTABLE EVENTS AND IMPACTS}

Figure 7.63 provides a schematic of notable events across New Zealand during 2020. Significant smoke and haze from Australian bushfires affected New Zealand for several days starting 1 January. The smoke and dust associated with this event contributed to the deposition of a particulate layer over parts of the Southern Alps, causing an unusual brown discoloration of the snow that persisted for several months.

From late-December 2019 through until February 2020, several locations across New Zealand observed record or near-record dry spells (defined here as 15 consecutive days or more with less than $1 \mathrm{~mm}$ of rain on any one day), with much of the North Island and northern South Island affected by meteorological drought. Most notably, a 64-day dry spell was recorded in Blenheim, making it the longest dry spell on record for the town.

From 1 to 4 February, very heavy rain fell in Southland and Otago. During this period, Milford Sound (Southland, South Island) recorded $1104 \mathrm{~mm}$ of rainfall (equivalent to $243 \%$ of its average February rainfall). A State of Emergency was declared, with 380 people stranded due to damaged roads. Approximately 4000 people were evacuated from their homes in Gore and Mataura due to flooding. 
Regions affected by meteorological drought

Regions where flood State of Emergency was declared

Regions affected by meteorological drought and floods

o

Cropp River: wettest


location $(11,532 \mathrm{~mm})$

○

Milford Sound highest 1-day rainfall total $(509 \mathrm{~mm}, 3 \mathrm{Feb})$

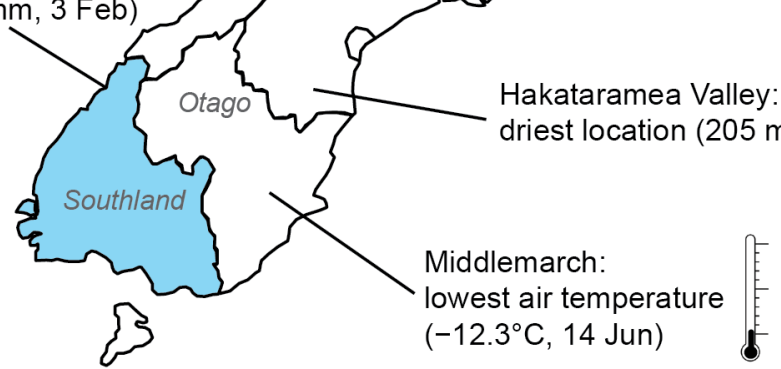

Fig. 7.63. Notable weather events and climate extremes for New Zealand in 2020. (Source: NIWA, https://niwa.co.nz/climate/ summaries/annual-climate-summary-2020.)

On 9 November, a low-pressure system situated east of New Zealand brought heavy rainfall to the eastern North Island. Napier (Hawke's Bay) recorded $242 \mathrm{~mm}$ of rainfall (equivalent to $31 \%$ of its average annual rainfall), resulting in landslides, power outages, road closures, and the declaration of a State of Emergency. It was the city's second-highest daily rainfall total since records began in 1870 . 


\section{Acknowledgments}

The editors thank the numerous National Meteorological and Hydrological Services for collecting and providing data for this report. Special thanks to all the authors in this chapter for their timely contributions, and the thoughtful and constructive comments from internal and external reviewers, and the document editors.

\section{Africa}

We would like to acknowledge the national and/or hydrometeorological services/bureaus of Morocco, Algeria, Egypt, Senegal (National Aviation and Meteorology Agency), Nigeria, Ethiopia, Kenya, Tanzania, Burundi, Rwanda, South Africa, Madagascar, Seychelles, Comoros Mayotte (France), Reunion (France), and Mauritius.

- We acknowledge support by the NOAA-CPC International Desk. Global data sets from NCEP./NCAR and GPCP are acknowledged.

- Samson Hagos and Zhe Feng are supported by the U.S. Department of Energy Office of Science Biological and Environmental Research as part of the Atmospheric Systems Research (ASR) Program.

\section{Europe}

- Valuable climate information was provided by National Meteorological and Hydrological Services of the WMO RA VI Region, either by direct submission to the authors or via the web.

- Valentina Khan acknowledges the support of Ministry of Science and Higher Education of the Russian Federation (Agreement No.075-15-2021-577 with A.M. Obukhov Institute of Atmospheric Physics RAS).

\section{Asia}

- The following grants (China National Key R\&D Program 2018YFC1505806 and 2018YFA0605604, NSF AGS-2006553, and NOAA grant NA180AR4310298) are acknowledged. 


\section{APPENDIX 1: Chapter 7 - Acronyms}

\begin{tabular}{|c|c|}
\hline$A G C D$ & Australian gridded climate data \\
\hline AMJ & April-June \\
\hline AWAP & Australian Water Availability Project \\
\hline BNGRC & National Office for Risk and Disaster Management \\
\hline CA & Central America \\
\hline CAMS & Climate Anomaly Monitoring System \\
\hline CA-NWS & Central America National Weather Services \\
\hline CAR & Central Africa republic \\
\hline CMORPH & CPC Morphing Technique \\
\hline CONUS & contiguous United States \\
\hline COSPPac & Climate and Oceans Support Program in the Pacific \\
\hline $\mathrm{CP}$ & central Pacific \\
\hline CPC & Climate Prediction Center \\
\hline DJF & December-February \\
\hline DRC & Democratic Republic of Congo \\
\hline ECCC & Environment and Climate Change Canada \\
\hline EM-DAT & Emergency Events Database \\
\hline ENSO & El Niño-Southern Oscillation \\
\hline EP & eastern Pacific \\
\hline GHA & Greater Horn of Africa \\
\hline GHCN & Global Historical Climate Network \\
\hline GPCC & Global Precipitation Climatology Centre \\
\hline IDI & Integrated Drought Index \\
\hline IDP & Internally Displaced People \\
\hline INPE & National Institute for Space Research \\
\hline 10 & Indian Ocean \\
\hline ISMR & Indian summer monsoon rainfall \\
\hline ITCZ & intertropical Convergence Zone \\
\hline JAS & July-September \\
\hline JFM & January-March \\
\hline J & June-July \\
\hline JJAS & June-September \\
\hline JTWC & Joint Typhoon Warning Center \\
\hline LTA & long-term average \\
\hline MAM & March-May \\
\hline MSE & moist static energy \\
\hline NCEP/NCAR & $\begin{array}{l}\text { National Centers for Environmental Prediction/National Center for } \\
\text { Atmospheric Research }\end{array}$ \\
\hline NEM & Northeast monsoon \\
\hline $\mathrm{NH}$ & Northern Hemisphere \\
\hline NIWA & National Institute of Water and Atmospheric Research \\
\hline OND & October-December \\
\hline ONI & Oceanic Niño Index \\
\hline PNG & Papua New Guinea \\
\hline RCC-CM & Regional Climate Centre on Climate Monitoring \\
\hline RFE2 & rainfall estimates version 2 \\
\hline
\end{tabular}


Southern Hemisphere

SON

September-November

SPCZ

South Pacific Convergence Zone

SPI

SSA

standardized precipitation index

SST

SSTA

TC

UN

WNP

YRV

Southern South America

sea surface temperature

sea surface temperature anomaly

tropical cyclone

United Nations

western North Pacific

Yangtze River Valley 


\section{APPENDIX 2: Supplemental Materials}

\begin{tabular}{|c|c|c|c|}
\hline Nation & $\begin{array}{l}\text { Temperature } \\
\text { start of record }\end{array}$ & $\begin{array}{l}\text { Precipitation start } \\
\text { of record }\end{array}$ & Source \\
\hline European average & 1950 & 1950 & $\mathrm{GHCN}^{1}$ data \\
\hline Albania (Korce) & 1963 & 1963 & CLIMAT $^{2}$ \\
\hline Andorra & 1950 & 1950 & $\mathrm{NMHS}^{3}$ \\
\hline Armenia & 1935 & 1935 & NMHS \\
\hline Austria & 1767 & 1858 & NMHS \\
\hline Azerbaijan (Astara) & 1991 & 1991 & CLIMAT \\
\hline Belarus & 1881 & 1945 & NMHS \\
\hline Belgium & 1981 & 1981 & NMHS \\
\hline $\begin{array}{c}\text { Bosnia \& Herzegovina } \\
\text { (Banja Luka) }\end{array}$ & 1955 & 1955 & CLIMAT \\
\hline Bulgaria & 1930 & 1954 (Burgas) & NMHS/CLIMAT \\
\hline Croatia (Split/Marjan) & 1949 & 1949 & CLIMAT \\
\hline Cyprus (Nicosia) & 1899 & 1899 & NMHS \\
\hline Czechia & 1961 & 1961 & NMHS \\
\hline Denmark & 1873 & 1874 & NMHS \\
\hline Estonia & 1961 & 1961 & NMHS \\
\hline Finland (Helsinki) & 1900 & 1961 & NMHS \\
\hline France & 1900 & 1959 & NMHS \\
\hline Georgia & 1956 & 1881 (Tbilisi) & NMHS \\
\hline Germany & 1881 & 1881 & NMHS \\
\hline Greece & 1960 & 1949 (Athens) & NMHS/CLIMAT \\
\hline Hungary & 1901 & 1901 & NMHS \\
\hline Iceland (Stykkishólmur) & 1900 & 1856 & NMHS \\
\hline Ireland & 1900 & 1900 & NMHS \\
\hline Israel & 1951 & 1935 (Deganya) & NMHS \\
\hline Italy & 1961 & 1949 (Alghero) & NMHS/CLIMAT \\
\hline Jordan (Amman) & 1981 & 1981 & NMHS \\
\hline Kazakhstan & 1941 & 1941 & NMHS \\
\hline Latvia & 1924 & 1924 & NMHS \\
\hline Lebanon (Beirut) & 1949 & 1949 & CLIMAT \\
\hline Lithuania & 1961 & 1887 (Vilnius) & NMHS \\
\hline Luxembourg (Findel) & 1947 & 1947 & NMHS \\
\hline Malta (Luqa) & 1923 & 1949 & NMHS/CLIMAT \\
\hline Moldova (Chisinau) & 1886 & 1891 & NMHS \\
\hline Monaco & not available & not available & - \\
\hline Montenegro (Plevlja) & 1955 & 1955 & CLIMAT \\
\hline Netherlands & 1901 & 1901 & NMHS \\
\hline $\begin{array}{l}\text { North Macedonia } \\
\text { (Bitola) }\end{array}$ & 1955 & 1955 & CLIMAT \\
\hline
\end{tabular}




\begin{tabular}{|c|c|c|c|}
\hline Nation & $\begin{array}{l}\text { Temperature } \\
\text { start of record }\end{array}$ & $\begin{array}{l}\text { Precipitation start } \\
\text { of record }\end{array}$ & Source \\
\hline Norway & 1900 & 1900 & NMHS \\
\hline Poland & 1951 & 1951 & NMHS \\
\hline Portugal & 1931 & 1931 & NMHS \\
\hline Romania & 1961 & 1954 (Bistrita) & NMHS/CLIMAT \\
\hline Russia, European part & 1936 & 1936 & NMHS \\
\hline Serbia & 1951 & 1951 & NMHS \\
\hline Slovakia & 1951 & 1961 & NMHS \\
\hline Slovenia & 1961 & 1961 & NMHS \\
\hline Spain & 1965 & 1965 & NMHS \\
\hline Sweden & 1860 & 1860 & NMHS \\
\hline Switzerland & 1864 & 1864 & NMHS \\
\hline $\begin{array}{c}\text { Syrian Arab Republic } \\
\text { (Aleppo) }\end{array}$ & 1960 & 1960 & CLIMAT \\
\hline Turkey & 1971 & 1949 (Adana) & NMHS \\
\hline Ukraine & 1891 & 1891 & NMHS \\
\hline United Kingdom & 1884 & 1862 & NMHS \\
\hline \multicolumn{4}{|c|}{ 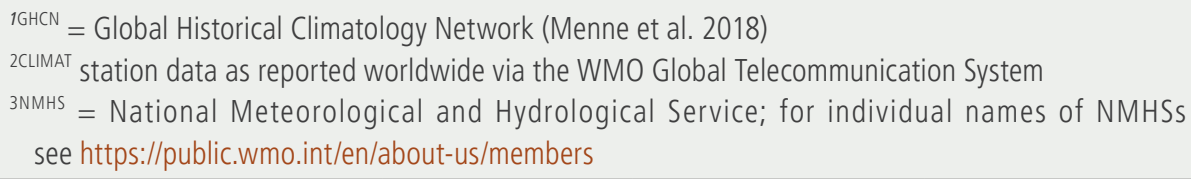 } \\
\hline
\end{tabular}




\section{References}

Amador, J. A., 1998: A climatic feature of the tropical Americas: The trade wind easterly jet. Top. Meteor. Oceanogr., 5, 91-102.

—, 2008. The Intra-Americas Seas Low-Level Jet (IALLJ): Overview and future research. Ann. N. Y. Acad. Sci., 1146, 153-188, https://doi.org/10.1196 lannals.1446.012.

-, E. J. Alfaro, H. G. Hidalgo, and B. Calderón, 2011: Central America [in "State of the Climate in 2010"]. Bull. Amer. Meteor. Soc., 92, S182-S183, https://doi. org/10.1175/1520-0477-92.6.S1.

-, E. R. Rivera, A. M. Durán-Quesada, G. Mora, F. Sáenz, B. Calderón, and N. Mora, 2016a: The easternmost tropical Pacific. Part I: A climate review. Int. J. Trop. Biol., 64, S1-S22.

- A. M. Durán-Quesada, E. R. Rivera, G. Mora, F. Sáenz, B. Calderón, and N. Mora, 2016b: The easternmost tropical Pacific. Part II: Seasonal and intraseasonal modes of atmospheric variability. Int. J. Trop. Biol., 64, S3-S57.

BoM, 2020: Special Climate Statement 73-Extreme heat and fire weather in December 2019 and January 2020. Bureau of Meteorology, 17 pp., http:// www.bom.gov.au/climate/current/statements/scs73.pdf.

Caribbean Institute for Meteorology and Hydrology, 2020: Caribbean Drought Bulletin Vol VI - VII, CIMH CRCC, accessed 27 January 2021, https://rcc.cimh. edu.bb/drought-bulletin-archive/.

Chang, C. P., Y. S. Zhang, and T. Li, 2000a: Interannual and interdecadal variations of the East Asian summer monsoon and tropical Pacific SSTs. Part I: Roles of the subtropical ridge. J. Climate, 13, 4310-4325, https://doi. org/10.1175/1520-0442(2000)013<4310:IAIVOT>2.0.C0;2.

,$- \ldots$, and _ $2000 \mathrm{~b}$ : Interannual and interdecadal variations of the East Asian summer monsoon and tropical Pacific SSTs. Part II: Meridional structure of the monsoon. J. Climate, 13, 4326-4340, https://doi.org/10.1175/15200442(2000)013<4326:IAIVOT>2.0.C0;2.

Cuhna, A. P., and Coauthors, 2019: Extreme drought events in over Brazil from 2011 to 2019. Atmosphere, 10, 642, https://doi.org/10.3390/atmos10110642

Elagib, N. A., I. S. Al Zayed, S. A. G. Saad, M. I. Mahmood, M. Basheer, and A. H. Fink, 2021: Debilitating floods in the Sahel are becoming frequent. J. Hydrol., 599, 126362, https://doi.org/10.1016/j.jhydrol.2021.126362.

Enomoto, T., B. J. Hoskins, and Y. Matsuda, 2003: The formation mechanism of the Bonin high in August. Quart. J. Roy. Meteor. Soc., 129, 157-178, https://doi. org/10.1256/qj.01.211.

Evans, A., D. A. Jones, R. Smalley, and S. Lellyett, 2020: An enhanced gridded rainfall analysis scheme for Australia. Bureau Research Rep. 041, Bureau of Meteorology, 39 pp., http://www.bom.gov.au/research/publications/researchreports/BRR-041.pdf.

FAN, 2020: Incendios forestales en Bolivia 2019-2020. Accessed 25 January 2021, http://incendios.fan-bo.org/Satrifo/?p=3987.

Giannini, A., R. Saravanan, and P. Chang, 2003: Oceanic forcing of Sahel rainfall on interannual to interdecadal time scale. Science, 302, 1027-1030, https:// doi.org/10.1126/science.1089357.

Gill, A. E., 1980: Some simple solutions for heat-induced tropical circulation. Quart. J. Roy. Meteor. Soc., 106, 447-462, https://doi.org/10.1002/qj.49710644905.

Hidalgo, H. G., E. J. Alfaro, J. A. Amador, and A. Bastidas, 2019: Precursors of quasi-decadal dry-spells in the Central America Dry Corridor. Climate Dyn., 53, 1307-1322, https://doi.org/10.1007/s00382-019-04638-y.

Janicot, S., S. Trzaska, and I. Poccard, 2001: Summer Sahel-ENSO teleconnection and decadal time scale SST variations. Climate Dyn., 18, 303-320, https://doi. org/10.1007/s003820100172.
Jones, D. A., W. Wang, and R. Fawcett, 2009: High-quality spatial climate datasets for Australia. Aust. Meteor. Oceanogr. J., 58, 233-248, https://doi. org/10.22499/2.5804.003.

Li, T., and B. Wang, 2005: A review on the western North Pacific monsoon: Synoptic-to-interannual variabilities. Terr. Atmos. Ocean. Sci., 16, 285-314, https:// doi.org/10.3319/TA0.2005.16.2.285(A).

_ $239 \mathrm{pp}$.

— - B. Wang, B. Wu, T. J. Zhou, C. P. Chang, and R. H. Zhang, 2017: Theories on formation of an anomalous anticyclone in western North Pacific during El Niño: A review. J. Meteor. Res., 31, 987-1006, https://doi.org/10.1007/ s13351-017-7147-6.

Magaña, V., J. A. Amador, and S. Medina, 1999: The midsummer drought over Mexico and Central America. J. Climate, 12, 1577-1588, https://doi. org/10.1175/1520-0442(1999)012<1577:TMDOMA>2.0.C0;2.

Marengo, J. A., and Coauthors, 2021: Extreme drought in the Brazilian Pantanal in 2019-2020: Characterization, causes, and impacts. Front. Water, 3, 639204, https://doi.org/10.3389/frwa.2021.639204.

Martin, E. R., and C. D. Thorncroft, 2014: The impact of the AMO on the West African monsoon annual cycle. Quart. J. Roy. Meteor. Soc., 140, 31-46, https:// doi.org/10.1002/qj.2107.

Mohino, E., S. Janicot, and J. Bader, 2011: Sahel rainfall and decadal to multidecadal sea surface temperature variability. Climate Dyn., 37, 419-440, https://doi.org/10.1007/s00382-010-0867-2.

Nurse, M., 2020: Droughts, hurricanes, pandemic, and hope: Current realities impacting Caribbean agriculture. CARICOM Today, 5 June, accessed 19 March 2021, https://today.caricom.org/2020/06/03/droughts-hurricanes-pandemicand-hope-current-realities-impacting-caribbean-agriculture/.

SENAMHI, 2020: Datos preliminares, boletines agroclimáticos y reportes hidrológicos 2020. Accessed 25 January 2021, www.senamhi.gob.bo/boletines.

Taylor, M., D. Enfield, and A. Chen, 2002: Influence of the tropical Atlantic versus the tropical Pacific on Caribbean rainfall. J. Geophys. Res., 107, 3127, https:// doi.org/10.1029/2001JC001097.

Trewin, B., 2018: The Australian Climate Observations Reference Network - Surface Air Temperature (ACORN-SAT) version 2. Bureau Research Rep. 032, Bureau of Meteorology, 57 pp., http://www.bom.gov.au/climate/change/acornsat/documents/BRR-032.pdf.

Wang, B., R. G. Wu, and T. Li, 2003: Atmosphere-warm ocean interaction and its impacts on Asian-Australian monsoon variation. J. Climate, 16, 1195-1211, https://doi.org/10.1175/1520-0442(2003)16<1195:AOIAll>2.0.CO;2.

WMO, 2020: WMO issues airborne dust bulletin as historic event hits Caribbean. WMO News, 26 June, accessed 19 March 2021, https://public.wmo.int/en/media/news/wmo-issues-airborne-dust-bulletin-historic-event-hits-caribbean.

Wu, B., T. Zhou, and T. Li, 2009: Seasonally evolving dominant interannual variability mode over the East Asia. J. Climate, 22, 2992-3005, https://doi. org/10.1175/2008JCLI2710.1.

Zhang, Q., and Coauthors, 2021: Understanding the variability of the rainfall dipole in West Africa using the EC-Earth last millennium simulation. Climate Dyn., 57, 93-107, https://doi.org/10.1007/s00382-021-05696-x. 
